\title{
Colecionismos, práticas de campo e representações
}

\author{
Maria Margaret Lopes \\ Alda Heizer \\ orgs.
}

\section{SciELO Books / SciELO Livros / SciELO Libros}

LOPES, MM., and HEIZER, A., orgs. Colecionismos, práticas de campo e representações [online]. Campina Grande: EDUEPB, 2011. 280 p. Ciência \& Sociedade collection. ISBN 978-85-7879-079-0.

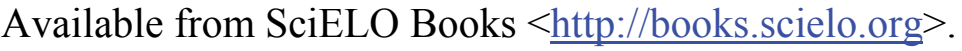

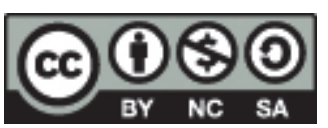

All the contents of this work, except where otherwise noted, is licensed under a Creative Commons Attribution-Non Commercial-ShareAlike 3.0 Unported.

Todo o conteúdo deste trabalho, exceto quando houver ressalva, é publicado sob a licença Creative Commons Atribuição Uso Não Comercial - Partilha nos Mesmos Termos 3.0 Não adaptada.

Todo el contenido de esta obra, excepto donde se indique lo contrario, está bajo licencia de la licencia Creative Commons Reconocimento-NoComercial-CompartirIgual 3.0 Unported. 
Maria Margaret Lopes (Orgs.) Alda Heizer

\section{Colecionismos, práticas de campo e representações}

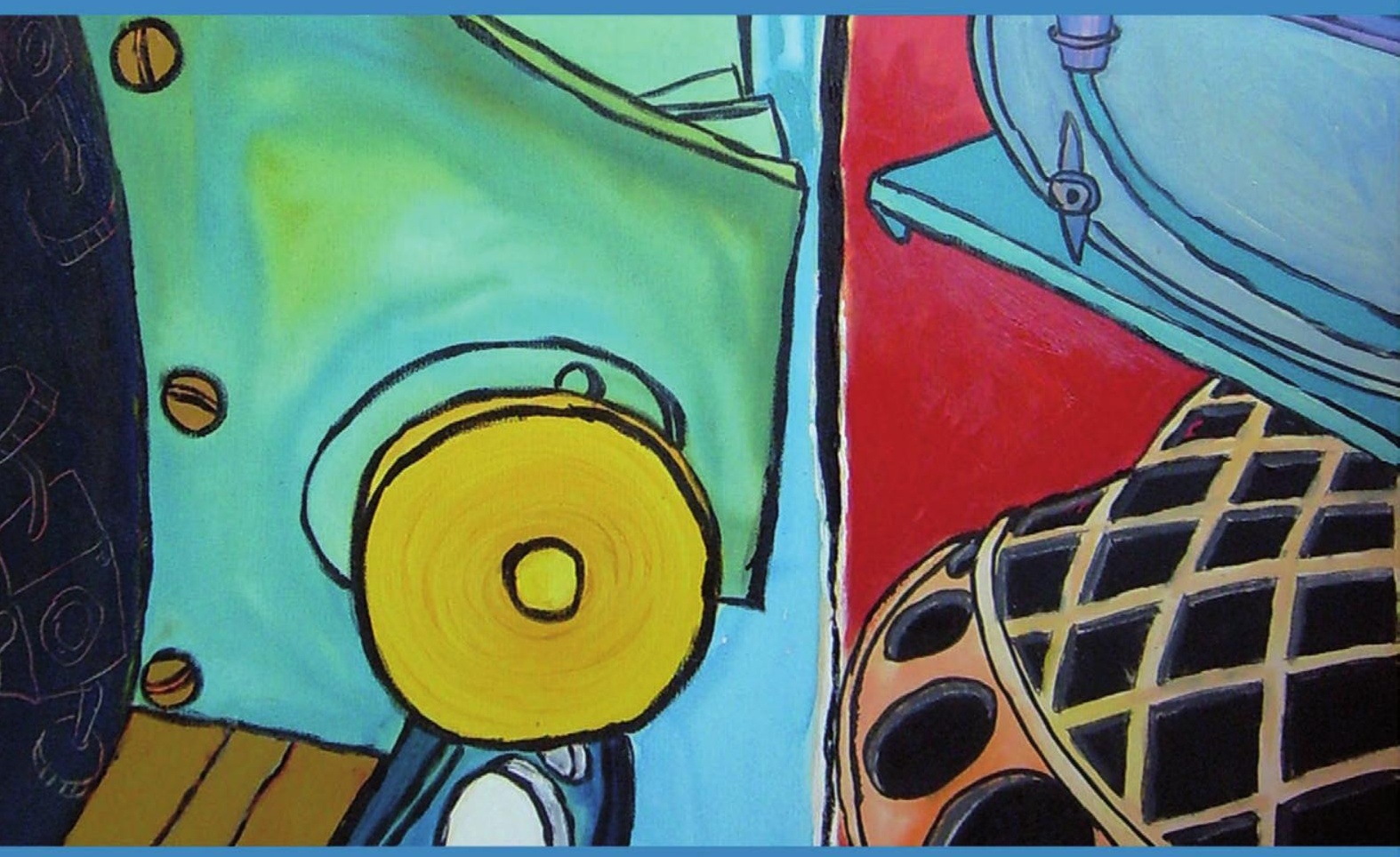

INing

\&SOCIIDNDS 


\section{Colecionismos, práticas de campo e representações}




\section{uepb \\ Universidade Estadual da Paraíba \\ Prof. Marlene Alves Sousa Luna | Reitor \\ Prof. Aldo Bezerra Maciel | Vice-Reitor}

eduepb

Editora da Universidade Estadual da Paraíba

Cidoval Morais de Sousa | Diretor

\section{Conselho Editorial}

Presidente

Luciano do Nascimento Silva

\section{Conselho Editorial}

Célia Marques Teles - UFBA

Dilma Maria Brito Melo Trovão - UEPB

Djane de Fátima Oliveira - UEPB

Gesinaldo Ataíde Cândido - UFCG

Joseilda de Sousa Diniz - UEPB

Joviana Quintes Avanci - FIOCRUZ

Marcionila Fernandez - UEPB

Rosilda Alves Bezerra - UEPB

Waleska Silveira Lira - UEPB

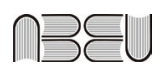

Editora filiada a ABEU

EDITORA DA UNIVERSIDADE ESTADUAL DA PARAIIBA

Rua Baraúnas, 351 - Bairro Universitário - Campina Grande-PB - CEP 58429-500

Fone/Fax: (83) 3315-3381 - http://eduepb.uepb.edu.br - email: eduepb@uepb.edu.br 
Maria Margaret Lopes

Alda Heizer

(Organizadoras)

\section{Colecionismos, práticas de campo e representações}

\section{Aeduepb}

Campina Grande-PB

2011 
Copyright (C) EDUEPB

A reprodução não-autorizada desta publicação, por qualquer meio, seja total ou parcial, constitui violação da Lei n 9.610/98.

\section{Editora da Universidade Estadual da Paraíba}

Cidoval Morais de Sousa | Diretor

\section{Design Gráfico}

Jefferson Ricardo Lima Araujo Nunes

Leonardo Ramos Araujo

\section{Divulgação}

Zoraide Barbosa de Oliveira Pereira

\section{Revisão Linguística}

Elizete Amaral de Medeiros

\section{Capa}

Arão de Azevedo Souza

\section{Capa}

Altazimute XVI - 2004

Acrílico de Almico - Coleção Particular: Cibele Cazelli

Depósito legal na Biblioteca Nacional, conforme Lei n 10.994 , de 14 de dezembro de 2004.

FICHA CATALOGRÁFICA ELABORADA PELA fBIBLIOTECA CENTRAL - UEPB

C691 Colecionismo, prática de campo e representações./ Maria Margaret Lopes, Alda Heizer (Organizadoras). - Campina Grande: EDUEPB, 2011.

268 p.: Il.

\section{ISBN 978-85-7879-079-0}

1. Colecionismo. 2. Plantas e Animais. 3. Museologia. 4. Historiografia-Uruguai. I. Lopes, Maria Margaret. II. Heizer, Alda. III. Título. 


\section{Sumário}

\section{9| Justificativa}

\section{Capítulo 1}

Bonpland, Saint-Hilaire e o Megatherium nas

11 coleções de cartas de Dámaso Antonio Larrañaga (1771-1848)

Maria Margaret Lopes

Alda Lúcia Heizer

\section{Capítulo 2}

29 Los pintores de la Real Expedición Botánica a Nueva España (1787-1803)

Graciela Zamudio Varela

\section{Capítulo 3}

41 Perspectiva histórica da evolução do conceito de museu em Portugal

João Brigola

\section{Capítulo 4}

$47 \begin{aligned} & \text { Las rutas del saber El tráfico de manuscritos } \\ & \text { iberoamericanos en la primera mitad del siglo XIX }\end{aligned}$ Irina Podgorny

\section{Capítulo 5} Museu Nacional do Rio de Janeiro em 1922 Capítulo Miriam Junghans 


\section{Capítulo 6}

73 Museos provinciales y redes

de intercambio en la Argentina

Susana V. García

\section{Capítulo 7}

Colecciones de cráneos, fotografías y

91 manuscritos en el desarrollo de la antropología

física y de la etnografía lingüística

en la Argentina a fines del siglo XIX

Máximo Farro

\section{Capítulo 8}

Coleção Temática de Plantas Medicinais um espaço de interlocução com a sociedade

Yara Lucia de Oliveira Britto

\section{Capítulo 9}

$115 \mid \begin{aligned} & \text { Transacciones, intercambios y circulación } \\ & \text { de objetos en el Museo Histórico y Colonial } \\ & \text { de la provincia de Buenos Aires (Argentina) } \\ & \text { durante la década de } 1920 \text { y 1930" }\end{aligned}$

María Elida Blasco

\section{Capítulo 10}

$127 \begin{aligned} & \text { Museus disciplinares e museus temáticos a busca } \\ & \text { por novos caminhos }\end{aligned}$

Luisa Maria Gomes de Mattos Rocha

\section{Capítulo 11}

$135 \mid \begin{aligned} & \text { Formación de museos y colecciones } \\ & \text { a fines del siglo XIX en las provincias }\end{aligned}$ argentinas de Entre Ríos y Corrientes 


\section{Capítulo 12}

147| A coleção do Museu de Astronomia e Ciências Afins Marcio Ferreira Rangel

\section{Capítulo 13}

155 Centro de Documentação Digital em História da Ciência (CDHC)

Adailton Ferreira dos Santos

\section{Capítulo 14}

167 Orquidofilia com ciência: colecionismo e divulgação na revista Orquídea Valéria Mara Silva Bernardo Jefferson de Oliveira

\section{Capítulo 15}

181 A Química no Melhoramento da Produção Agrícola e sua Divulgação na Revista Agrícola Bruno Capilé Nadja Paraense dos Santos

\section{Capítulo 16}

193 Estrangeiros na criação da Escola Agrícola da Bahia (1863-1877)

Nilton de Almeida Araújo

\section{Capítulo 17}

207 Zoológico e o Horto Botânico do Museu Paraense de História Natural e Etnografia (1897-1900) Diego Ramon Silva Machado José Jerônimo de Alencar Alves 


\section{Capítulo 18}

$225 \mid$\begin{tabular}{l|l} 
O Museu Nacional na Exposição \\
Universal de Paris em 1889
\end{tabular}

Regina Maria Macedo Costa Dantas

Nadja Paraense dos Santos

\section{Capítulo 19}

"Certamen Agricola, Industrial e de Manufaturas":

237 o aparecimento do Novo Século e a participação de Sergipe nas exposições nacionais

Fabrícia de Oliveira Santos

Alexandrina Luz Conceição

\section{Capítulo 20}

255 Cultura de exposições em São Paulo, no século XIX

Heloisa Barbuy

\section{Capítulo 21}

Coleccionistas, aficionados y arqueólogos en la

267 conformación de las colecciones arqueológicas del Museo de La Plata, Argentina (1930-1950)

María Alejandra Pupio 


\section{Justificativa}

As coleções científicas, as práticas de campo, suas representações artísticas/científicas, suas relações comerciais ocupam cada vez mais um lugar privilegiado na produção historiográfica internacional.

A centralidade das coleções, das práticas de campo, das imagens nas culturas das ciências; a importância dos periódicos, dos congressos, das exposições, das atividades de comunicação pública nos processos de circulação das ciências podem ser identificadas em um número significativo de trabalhos no Brasil e na América Latina, na confluência de diferentes áreas do conhecimento.

Os museus, jardins botânicos, zoológicos, serviços geológicos, hospitais, institutos de agricultura e engenharia, repartições militares, secretarias de estado são instituições que conservam a tradição de práticas colecionistas, de ciências museológicas/diagnósticas nos dizeres de Pickstone. Constituem-se em poderosas instituições de controle de políticas, de concepções científicas, de práticas comunicacionais.

Por toda a América Latina, muitas de suas coleções de objetos, imagens, fotografias, catálogos, textos, periódicos, correspondências reunidas há séculos permanecem à espera das necessárias análises contextuais, temporais, locais que esse livro pretende discutir. 


\section{1.}

\section{Bonpland, Saint-Hilaire e o Megatherium nas coleções de cartas de Dámaso Antonio Larrañaga (1771-1848)}

Maria Margaret Lopes ${ }^{1}$

Alda Lúcia Heizer ${ }^{2}$

\section{Persona}

Dámaso Antonio Larrañaga (1771-1848) é uma figura de destaque na historiografia uruguaia (Algorta Camusso, 1922). Mas, sua obra como naturalista é menos conhecida entre os historiadores das ciências, mesmo na América Latina (Camejo, 2008). Nascido em Montevidéu, filho de pai de origem basca e mãe de origem portuguesa, Larrañaga estudara no Real Colegio de San Carlos, em Buenos Aires e mais tarde ocupou posições controvertidas, mas de prestígio, no cenário político e religioso do Rio de la Plata. Consagrado no Rio de Janeiro, onde rezou sua 1 a missa, em Montevidéu atingiu o posto mais alto da hierarquia eclesiástica (Furlong, 1945). No fim da sua vida, já idoso e cego foi presidente da Comissão encarregada da organização do Museu de Montevidéu, criado em 4 de setembro de 1837 (Lopes and Podgorny, 2000).

Ao longo de sua trajetória, Larrañaga cultivou uma ampla rede de correspondentes que incluiam desde Artigas até seus familiares. Seu convívio com os eruditos de Buenos Aires e com a rede de amigos padres naturalistas, armada desde as aulas do Colégio de São Carlos também estão registradas em sua volumosa correspondência (Favaro,

1 Centro de Estudos de História e Filosofia da Ciência. Universidade de Évora; Diretora do Museu de Astronomia e Ciências Afins/MCT.

E-mail: mariamargaretlopesagmail.com

2 Instituto de Pesquisas Jardim Botânico do Rio de Janeiro

E-mail: aldaheizerajbrj.gov.br 
1950). A essa rede pertenciam entre outros, Tomás Javier Gomensoro (1776-1841), Saturnino Segurola (1776-1854) e Bartolomé Doroteo Muñoz (1776-1831) (Di Stefano, no prelo). Em suas cartas, Gomensoro, que em 1818 era pároco em Canelones, no interior do atual Uruguai, informava Larrañaga sobre as espécies botânicas que encontrava em suas herborizações, enviava-lhe sementes, o convidava para realizar excursões para coleta de produtos naturais e partilhava seus projetos arquitetônicos para a construção da igreja local ${ }^{3}$.

Larrañaga foi nomeado diretor da Biblioteca Nacional de Montevideo inaugurada em 26 de maio de 1816 e destruída no ano seguinte pela ocupação luso-brasileira. Antes disso, fora nomeado subdirector da Biblioteca Pública de Buenos Aires entre 1813 e 1815, fato que seus correspondentes não deixariam de acompanhar. O conhecido comerciante inglês de minerais, John Mawe (1766-1829) (Torrens, 1992), que mantinha correspondência com Larrañaga desde 1806, quando se conheceram em Montevidéu, voltou a lhe oferecer seus serviços, nesta ocasião, sem deixar de pedir em troca, alguns exemplares de conchas terrestres e fluviais. Mawe, que já estava de volta a Londres, em 1813, se ofereceu para intermediar a compra de livros, que poderiam ser necessários para a Biblioteca. Informava que havia transferido sua loja para o centro de Londres (149 Strand, "London's busiest shopping street") e que sua coleção de livros voltava-se principalmente para a obras de Química, Mineralogia e Agricultura, sendo que os clássicos estavam fora de seu campo de ação. Seu principal interesse - o comércio de pedras preciosas e minerais havia aumentado muito, desde seu retorno do Rio de Janeiro 4 .

O padre Larrañaga sobreviveu em cargos de cada vez maior poder, em diferentes situações políticas. Tendo sido hábil negociador, integrou o círculo mais próximo do general Carlos Frederico Lecor, o administrador português da Província Oriental ${ }^{5}$. Mesmo assim, ocuparia posteriormente, o posto de senador, quando da constituição da República uruguaia, em 1828. Larrañaga que passou grande parte de sua vida reunindo coleções e classificando as amostras que recolhia em suas viagens, uniu em sua morte todas as facções em luta na prolongada guerra civil uruguaia e sua obra científica tornou-se uma unanimidade.

3 Carta de Gomensoro a Larrañaga. Canelones, 23/08/1818. Larrañaga (1923, 247-249).

4 Carta de John Mawe a Larrañaga. London, 21/10/1813. (Favaro, 1950, 115-116).

5 O general Carlos Frederico Lecor- depois Barão de Laguna -, lutou nas guerras contra Napoleão, em Portugal e foi governador da praça de Elvas, no Alentejo português. Depois disso, foi o responsável pela organização de um exército e pela ocupação e administração da Provincia Oriental, de 1817 a 1825, a princípio a serviço do Reino Unido de Portugal, Brasil e Algarves e, posteriormente, de 1922 a 1925 a serviço do Império do Brasil. 
Sobre as proporções de seu trabalho ${ }^{6}$, o próprio Larrañaga daria seu testemunho em seu discurso inaugural, quando assumiu a direção da Biblioteca de Montevidéu, em 1816, dirigindo-se aos jovens e enaltecendo a importância dos estudos de todas as ciências e línguas nativas e estrangeiras para a riqueza das nações. Eram tantos os produtos naturais da região, que ele mesmo, naquela mesma sala da Biblioteca, entre suas diversas funções religiosas, havia classificado e descrito sistematicamente, mais de mil espécies desconhecidas dos três reinos da natureza (Larrañaga, 1924). Larrañaga, que era considerado excelente desenhista, ilustrava seus próprios textos. De seus desenhos de botânica, foram recuperadas um total de 135 láminas em 126 pranchas e identificadas 129, pertencentes a 103 gêneros e 51 famílias entre as mais 'vistosas' e indígenas das regiões do entorno de Montevidéu, mas também do norte do país, possivelmente do Departamento de Payssandú, que Larrañaga visitara em 1815. Entre esses desenhos 13 descrições são assinaladas como gênero ou espécie novas, e o eram até por volta de 1824, a exceção de uma - possivelmente pertencente a Panicum sabulorum de Lamarck, 1797 segundo a classificação de Herter (1928)7.

Seus peixes, cujas descrições e locais de pesca no rio de La Plata e em rios do interior do Uruguai constam de seus "Escritos" de 1814 (Zoologia, Pisces), foram identificados em termos de pelo menos 30 espécies marinhas, 25 de água doce e algumas impossíveis de serem identificadas (Devincenzi, 1925). No segundo volume desses "Diários" redigidos até por volta de 1823, há também descrições do território Oriental, costumes dos habitantes e comentários práticos sobre agricultura. Suas detalhadas memórias geológicas sobre a formação do Rio de La Plata e teorias diluvionistas ${ }^{8}$, apoiavam-se nos estudos de suas volumosas coleções de conchas. Tais conchas obtidas por envio de correspondentes, coletadas em em suas viagens ou, como as pelágicas, que havia comprado 'a unos Indios en La Paz entre várias drogas' lhe permitiam classificar novas espécies. Por exemplo, as 'piedras de águila' vendidas pelos indígenas foram classificadas como um novo gênero - Guarcarite - da família das terebrátulas. Aos geólogos, que não tinham outros instrumentos que a

6 Suas obras e fragmentos de trabalhos circularam, como atestam seus correspondentes. No entanto permaneceram quase todos inéditos a sua época, tendo sido publicados, no primeiro tomo dos Anales del Museo de Nacional de Montevideo com uma introdução de Carlos M. de Pena (Pena, 1897) e no início dos anos vinte, em uma homenagem do Instituto Histórico y Geográfico del Uruguay.

7 Agradecemos a Irina Podgorny o acesso a esse artigo.

8 Para uma análise de suas memórias geológicas sobre a formação do Rio de La Plata e sobre a Pedra de cal de Buenos Aires ver (Lopes e Varela, 2010) 
observação, já que tudo que encontravam já estava em ruínas, recomendava trazer em seu auxílio a antomia comparada, a física, a química, a astronomia, a história, a mineralogia, a botânica, a docimástica e todas as ciências exatas, físicas e naturais, para examinar as épocas, as causas, os efeitos dos fenômenos naturais (Larrañaga, 1923, 24)

A persona construída sobre Larrañaga na historiografia não é exceção na comunidade de naturalistas, que realizaram suas obras científicas em meio a sua atução política e ou eclesiástica e durante as guerras, nas regiões do Rio de La Plata, que hoje integram o sul do Brasil, o Uruguai, o Paraguai e a Argentina. Em 1821, ainda no período da ocupação lusobrasileira dos territórios uruguaios, Larrañaga receberia de João VI, pelos serviços prestados ao Império Português, a comenda da Ordem de Cristo. Sobre essa condecoração o consulado norte-americano no Rio de Janeiro comunicaria ao seu país em tom de reprovação que o Dr. Larrañaga, pároco da igreja principal de Montevidéu, com poder sobre todas as pároquias da Província, homem de ciência, grande naturalista, de sentimentos liberais, amigo do país, sagaz e inteligente e contudo, subserviente aos portugueses, havia aceitado uma ordem de nobreza (Favaro, 1950). Antes disso, Larrañaga enquanto integrante da delegação de deputados de Montevidéu, havia sido recebido no Rio de Janeiro pessoalmente por D. João VI, o príncipe regente no Brasil. Os deputados lá estiveram, em 1817, - logo após a ocupação luso-brasileira - levando reivindicações e prestando vassalagem, para horror dessa vez, da diplomacia francesa, que preocupada com seus interesses no Prata, os considerava infames traidores. A sua volta do Rio de Janeiro, Larrañaga recebeu a primeira carta de Aimé Bonpland.

\section{Encontros e correspondentes}

As cartas trocadas entre Larrañaga e Aimé Bonpland (1773-1858), e Larrañaga e Aguste de Saint-Hilaire (1779-1853) justamente atestam que a circulação "dos mesmos dados" (Rudwick, 2005) entre potenciais interessados foi também um dos elementos constitutivos do estudo moderno das ciências botânicas, zoológicas, geológicas e paleontológicas, no sul da América. As cartas e os registros dos encontros que mantiveram deixam saber que os manuscritos de Larrañaga foram lidos, discutidos, referenciados. Os encontros de Bonpland e Saint-Hilaire com Larrañaga foram alguns dos muitos encontros que ocorreram entre naturalistas nos territórios que constituem o Uruguai e que foram possibilitados entre outros motivos, por uma maior abertura da América Portuguesa aos naturalistas de diversos países, após a transferência da corte portuguesa de Lisboa para o Rio de Janeiro, em 1808. 
A correspondência de Larrañaga permite saber que suas coleções foram examinadas, checadas, classificadas e divulgadas. A correspondência é também um manancial de informações sobre detalhes das trajetórias percorridas pelos naturalistas viajantes e coletores em suas missões naturalistas, diplomáticas e comerciais.

Nas cartas de Larrañaga são diversas as cautelosas, necessárias e evidentemente também retóricas, referências a suas insuficiências de recursos bibliográficos, relativizadas por suas menções aos livros que utiliza para suas classificações, ou nas que constata que algumas das espécies que julgava novas acabavam de ser publicadas. Não faltam também a valorização de seu próprio trabalho e as referências que atestavam sua erudição.

A correspondência entre Bonpland e Larrañaga ${ }^{9}$ inicia-se explicitamente pelo comércio de livros, em 1818, quando Larrañaga voltou de sua missão diplomática junto a D. João VI, no Rio de Janeiro. Bonpland chegara em Buenos Aires em 1816, possivelmente atraído pelos esforços diplomáticos que Bernardino Rivadavia buscara articular na Europa em prol do reconhecimento das Províncias Unidas do Rio de la Plata (Bell, 2010), antes da ocupação luso-brasileira.

Rapidamente desiludido, com o estado de guerra que encontrou, com suas coleções ainda embaladas, Bonpland escreve a Larrañaga, em busca de apoio e de um cliente potencial. Estabelecidas suas relações com os eruditos em Buenos Aires, é através dos amigos comuns de Buenos Aires, como Segurola e Bartomé Muñoz, que Bonpland se apresenta. Apostando em que Larrañaga pudesse ser um possível comprador dos livros de História Natural e dos livros sobre sua viagem com Humboldt, que trouxera consigo nessa sua nova viagem, propõe seu negócio. Informado também sobre uma certa vitalidade do comércio de livros no Rio de Janeiro e mesmo supondo que com a última viagem de Larrañaga, sua biblioteca particular e a de Montevidéu tivessem sido muito enriquecidas, Bonpland envia sua lista de livros disponíveis para compra, oferecendo inclusive a possibilidade de fazer descontos. Mas previne Larrañaga que se apressasse, porque oferecera também seus livros a possíveis compradores no Chile. Diz conhecer o interesse de Larrañaga pelas ciências, estar bem informado sobre seus trabalhos, e desejoso de conhecer suas coleções de plantas reunidas em suas viagens

9 Os comentarios que se seguem constam das cartas trocadas entre Bonpland e Larrañaga em: 02/26/1818; 04/02/1818; 05/25/1818; 09/15/1818; 11/10/1820. (Larrañaga, 1923, 257-275). 
pelos rios Paraná, Uruguai e suas ilhas de vegetações mais exuberantes do que as do entorno de Montevidéu ${ }^{10}$.

Larrañaga de fato comprou com $10 \%$ de desconto alguns livros de Bompland, referidos como Voyage de Humboldt et Bonpland, Zoologie; Humboldt tableaux de la nature; Schel. Dictionnaire de Sciences naturelles; Desfontaines: tableaux de l'École botanique; 'Plantae americanae' de Plumier. E embora Bonpland não possuisse o livro de nivelações barométricas e o Conspectus longitudinum que Larrañaga solicitara, como bom vendedor e para "encher o caixote" enviou outros mais ${ }^{11} \mathrm{e}$ sua lista de livros disponíveis na esperança de que a biblioteca pública os comprasse, e Larrañaga não o precisasse fazer. E ainda solicitava a Larrañaga a intermediação de seus negócios. Pedia ao padre se este poderia encontrar um livreiro em Montevidéu que vendesse os livros que não fossem comprados, ou os devolvesse a casa Roguin y Meyer.

Lamentando que parte das coleções de insetos, plantas e aves de Larrañaga teriam sido destruídas durante sua ausência de Montevidéu, na viagem ao Rio de Janeiro, Bonpland também lamentava que seu herbário de mais de 20.000 plantas bem determinadas, uma coleção preciosa de conchas e a coleção mineralógica, com todas as amostras que havia reunido em sua viagem com Humboldt, além de outras reunidas en França, estavam ainda, 18 meses apóa sua chegada as regiões do rio de La Plata, armazenadas sem uso. Menciona a "douce illusion" com que chegara a essas regiões da América, de que suas coleções fossem úteis para servir de base para algum estabelecimento de instrução pública ${ }^{12}$.

Bonpland ofereceu a Larrañaga uma versão de sua vinda a América. Tratava-se de uma portunidade de recuperar o tempo que perdera para as ciências, desde quando aceitara o posto d'Intendant des Domaines de l'Impératrice Joséphine. Emprego que teria aceitado, uma vez que não se concretizaram seus planos de continuar a trabalhar em conjunto com Humboldt, já que, quando voltaram a Europa, embora inda tivessem trabalhado algumas vezes juntos, Humboldt passara a se ocupar de política na Alemanha. Esperançoso, Bonpland comunica seus planos de ocupar o posto de naturalista e correspondente que a morte de Tadeo Haenke (1761-1817) ${ }^{13}$ deixara vago.

10 Carta de Bonpland para Larrañaga.Buenos Aires 13/02/1818 . (Larrañaga, 1923, 257-258).

11 Carta de Bonpland para Larrañaga. Buenos Aires 02/04/1818. (Larrañaga, 1923, 264-266).

12 Carta de Bonpland para Larrañaga. Buenos Aires 02/04/1818. (Larrañaga, 1923, 260-261).

13 Nascido na Boemia com estudos em Praga e Viena, o naturalista Tadeo Haenke integrou a expedição espanhola Malaspina e permaneceu nas regiões do Rio de La Plata, Bolívia e Peru até sua morte. 
Para apresentar seus trabalhos e valorizá-los, pedindo desculpas pela demora no envio de sua carta, Larrañaga ${ }^{14}$ dizia ter realizado seus trabalhos em poucas horas retiradas de seus momentos de descanso e mesmo assim interrompidas por suas inúmeras obrigações eclesiásticas. Larrañaga enviou a Bonpland cinco textos do reino animal em que trata de 62 mamíferos, 142 aves, 33 anfíbios e 65 peixes classificados segundo a 13ạ edição do sistema de Lineu. Os Diários de História Natural de Larrañaga, organizados entre 1808 e 1813, continham 2.000 descrições e classificações, seguindo Lineu, Lamarck, Gmelin e os embranchements de Cuvier para os animais. Embora Lineu fosse 'seu único mestre', Larrañaga destaca a própria originalidade de seu trabalho, acrescentando que como era preciso seguir a moda do século - de que está completamente a par (havia comprado recentemente a grande edição de Buffon por Sonini, os trabalhos de Cuvier), havia classificado seus mamíferos por novos métodos e havia acrescentado algumas inovações suas e de Felix Azara (1742-1821), já que a todos era permitido metodizar. Felix Azara fora engenheiro militar das comissões de limites entre Portugal e Espanha dos anos de 1750 e permanecia como uma referência fundamental para os estudos zoológicos da região.

Retóricas de parte a parte, essas cartas fornecem detalhes das situações que caracterizam esses encontros e intercâmbios de naturalistas de diferentes formações. Bonpland chega ao sul da América desejoso de um emprego em História Natural, além de suas missões diplomáticas, em uma região em guerra, tendo seus livros e a fama da viagem com Humboldt para vender em troca de informações, documentos, coleções de produtos naturais, desconhecendo os trabalhos e o prestígio dos naturalistas locais, a quem acaba por considerar.

Se dizendo impressionado e possivelmente estando impressionado, com o trabalho de Larrañaga, Bonpland diz que irá rever seus planos de enviar artigos para as publicações européias sobre a História Natural das regiões do Prata. Reconhecendo que Larrañaga possuia muitos mais conhecimentos do que ele sobre essas regiões do sul da América, Bonpland afirma a Larrañaga que não enviaria nada aos jornais europeus, antes de se encontrar com ele, saber suas intenções sobre publicações. Não se permitiria publicar sem o consentimento de Larrañaga trabalhos sobre os quais considerava que Larrañaga teria mil vezes mais direito que ele e que na verdade, Bonpland considerava propriedade de Larrañaga.

Entre diversos trabalhos, foi autor de diversos artigos no jornal El Telégrafo Mercantil e tinha um título de professor de Historia Natural das Provincias Unidas del Río de la Plata.

14 Carta de Larrañaga para Bonpland Buenos Aires 05/25/1818. (Larrañaga, 1923, 267-269). 
Frente as informações de Larrañaga de possuir partes de esqueletos do que Cuvier havia classificado como Megatherium, Bonpland o aconselha a não enviar suas coleções.

Em uma de suas cartas - de 15 de setembro 1818 -, Bonpland aconselhava Larrañaga, a conservar, os ossos que possuia, se esses fossem do mesmo tipo daqueles do grande esqueleto encontrado em Lujan, que Bonpland havia visto no Museu de Madrid. Bonpland afirma, que Larrañaga poderia fazer um desenho reduzido e enviá-lo a Europa e lhe ficariam muito agradecidos desse obséquio. Avisa que Cuvier é a única pessoa a quem isso convém, e que talvez fosse melhor dirigir os desenhos ao Ministro do Interior para que esse os enviasse ao Museu de História Natural, ou diretamente para o Museu e escrever a Cuvier em qualquer dos dois casos. Pedia desculpas pelas sugestões, mas the pedia a convicção de que o fazia em seu interesse e no de seu país. Ainda lhe informava e pedia apoio para suas articulações para a criação do Museu de História Natural de Corrientes, em Paraná. Bonpland que passaria o resto dos seus dias nas regiões fronteiriças dos atuais Brasil, Argentina, Paraguai, Uruguai, ainda veria, finalmente na década de 1850 os primeiros esforços para a organização de um museu de Historia Natural em Corrientes (Podgorny e Lopes, 2008).

O Megatherium também seria tema da correspondência com naturalista francês Auguste de Saint-Hilaire (1779-1853). Quando SaintHilaire o procurou em sua casa, em 1820, Larrañaga já gozava de um amplo prestígio eclesiático, político e científico indissociáveis. Em Montevidéu, entre 3 e 23 de novembro de 1820, Saint-Hilaire que viajava pelo então sul do Império português na América - com o apoio do Muséum de Histoire Naturelle, de Paris e com autorização do governo estabelecido no Rio de Janeiro -, passara todas as horas que pode e com imenso prazer em companhia de Larrañaga. Auguste de Saint-Hilaire (Kury, 1995) também havia chegado ao Brasil em 1816, incorporado a missão diplomática francesa coordenada pelo duque de Luxemburgo (Saint-Hilaire, 1824). A missão se ocupava da resolução dos problemas de delimitação das fronteiras dos territórios do norte do Brasil com a Guiana francesa, que havia sido ocupada pelas tropas portuguesas em 1809, em represália à invasão napoleônica de Portugal. Saint-Hilaire foi apresentado ao padre Larrañaga por um sr. Chapre, cunhado de um sr. Cavailler, que exercia medicina. Suas conversas, visitas conjuntas a instituições como a Biblioteca Pública, ou o Hospital, herborizações nos arredores de Montevidéu e consulta constante aos catálogos organizados por Larrañaga, com cerca de 700 plantas só do entorno de Montevidéu - mencionadas por Saint-Hilaire por seus respectivos 
números do catálogo -, informavam o naturalista francês de inúmeros aspectos da natureza da região e da analogia dos climas dessas regiões da América e da Europa. Tal analogia era confirmada pela facilidade, com que por exemplo, reconhecia os mesmos tipos de plantas (SaintHilaire, [1887] 2002).

Nas cartas que trocaram, Saint-Hilaire agradece a Larrañaga 0 documento de apresentação que este lhe dera, e que the valera em suas viagens pelo sul da América, a melhor acolhida entre as autoridades e curas. Saint Hilaire confirma ter encontrado a partir das indicações precisas do catálogo de Larrañaga plantas específicas, cujas classificações julgava não estarem ainda definidas, e outras, como as coletadas entre Montevidéu e Rio Negro, que pertenciam a famílias européias. Suas coletas em Las Víboras haviam sido magníficas. Em Colonia do Sacramento, Saint-Hilaire encontrou o -trebol singular- de que Larrañaga the havia falado. De Porto Alegre e do Rio de Janeiro prometia continuar enviando notícias. Ainda lhe pedia informações específicas sobre os meios de transporte, preços, condições de segurança e possibilidades reais de ir e voltar do Rio de Janeiro a Cordilheira dos Andes, entre os meses de setembro de 1821 e março de $1822^{15}$. Em resposta, Larrañaga lhe garantia que a viagem não só era possível como seria barata, uma vez que o Chile era considerado um dos países mais baratos do mundo. Quanto a segurança da viagem, el genio americano- era doce, hospitaleiro e respeitava as ciências. E, afirmando que algumas cartas de apresentação lhe seriam suficientes, assegurava, exibindo seu próprio prestígio e conhecimento do que se passava na região, que Saint-Hilaire receberia por parte de seus amigos os mesmos favores que anteriormente já haviam recebido Fresier, Teuvillé e Dombey - o ilustre companheiro de Ruiz e Pavón ${ }^{16}$, nas expedições espanholas ao Perú e Chile.

Essas viagens marcaram efetivamente a carreira de Saint-Hilaire e suas volumosas obras sobre a região. Em carta a Blainville, datada de janeiro de 1830, em busca de votos para sua admissão na Academia de Ciências de Paris, para onde foi eleito em 1830, Saint-Hilaire destaca entre seus títulos e atividades, particularmente, os seus seis anos de viagens no Brasil, na República Cisplatina e nas missões (Dwyer, 1955). Das viagens a algumas dessas regiões, para as quais as cartas de Larrañaga foram da maior utilidade, resultaram as mais de 7 mil espécies de plantas,

15 Carta de Saint-Hilaire a Larrañaga, Belem, 15/01/1821 (Larrañaga, 1923, 277-278).

16 Carta de Larrañaga a Saint-Hilaire, Montevidéu, 16/02/1821 (Larrañaga, 1923, 280-282). 
2000 pássaros 16000, insetos, 129 quadrúpedes e 35 répteis (4.500 delas desconhecidas), enviadas ao Muséum de Paris e a grande maioria de suas publicações. (Saint-Hilaire, 1823)

Algumas das cartas de Saint Hilaire foram entregues pessoalmente a Larrañaga por Friedrich Sellow (1789-1831) que também o acompanhou em herborizações que resultaram em amplas coletas e novas classificações. Sellow com autorizações e passes fornecidos pelo governo do Rio de Janeiro, que viajava comissionado pelo Museu de Berlim e pelo já então criado Museu Real do Rio de Janeiro, foi um dos naturalistas estrangeiros que mais forneceram coleções geológicas, paleontólogicas e zoológicas ao Museu Real do Rio de Janeiro à época, embora essas não se comparassem às enviadas a Berlim (Lopes, 1997). E foram seus envios de grandes ossadas fósseis ao Museu de Berlim, que permitiram a Weiss e D'Alton novas contribuições para as discussões ao debate sobre a existência ou não carapaças nos Megatérios (Podgorny, 2007).

Em sua correspondência, Saint-Hilaire ainda informara Larrañaga, em janeiro de 1821, que algumas de suas notas seriam enviadas para a Societé Philomatique de Paris para a qual Saint-Hilaire havia proposto o nome de Larrañaga como correspondente. Em setembro de 1822, Saint-Hilaire voltou a informar Larrañaga que as tais notas, junto com um memorando seu não haviam chegado a França ${ }^{17}$. Mas na mesma carta diz ter comunicado 'à notre savant Cuvier ce que vous me faites l-honneur de me mander relativement au Faton [sic] fossil. Comme il se propose de donner bientôt une 2ème édition de son ouvrage, il désire vivement que vous publiez quelque chose sur cet object intéressant, et me charge de vous en prier en son nom. Dans le cas ou cela ne vous conviendroit pas, vous pourriez m-envoyer une simple note dont il profiteroit, en vous citant, comme cela doit être.'

Em 29 de março de 1822, o conhecido navegador francês Louis Claude de Freycinet (1779-1842), autor de um dos primeiros mapas do litoral da Austrália, que em suas viagens de circunavegação também havia encontrado Larrañaga em Montevidéu, lhe escrevia, desculpandose pelo atraso em the enviar os livros que se encarregara de comprar em Paris. Nessa carta, além de solicitar a Larrañaga que the comunicasse suas observações metereológicas do ano de 1821 e dos próximos, também lhe informava que em breve receberia uma carta da Société de Géographie de Paris, propondo-o como correspondente. Também

17 Carta de Saint-Hilaire a Larrañaga, Paris, 19/09/1822 (Larrañaga, 1923, 291-293) 
reafirmava $\mathrm{O}$ interesse de Cuvier pelos trabalhos de Larrañaga: ' $\mathrm{Mr}$. Cuvier, auquel j'ai parlé de vos découvertes en histoire naturelle, serait fort satisfait des communications que vous voudriez bien lui faire-18

De fato, uma nota de Larrañaga acabou sendo publicada em: Saint-Hilaire, Auguste de Extrait d'une lettre de D. Damasio Larranhaga de Montevideo a ..."Note sur le Megatherium de Cuvier, l-Hydromis, et une varieté nouvelle de mais". Bulletin des Sciences par la Societé Philomatique de Paris, june 1823, p. 83. A mesma nota é referida por exemplo, pela Geological Society em 1823, em seu catálogo dos Scientific Papers compilados pela Royal Society em 1868. Trechos dessa mesma carta imortalizariam Larrañaga como "savant Brasilien", em uma referência a essa época em que os territórios da Banda Oriental, permaneciam anexados ao Brasil (Lopes, 1999). Seriam reproduzidos pela nota de Cuvier na segunda edição de suas Recherches sur les Ossemens Fossiles". Associando seu grande quadrúpede encouraçado (que Larrañaga não duvidava em classificar como Dasypus), ao Megatherium, Larrañaga inaugurou um debate que só se encerraria vinte anos depois envolvendo uma ampla gama de outros interessados, em diferentes regiões do mundo, como os diversos trabalhos de Irina Podgorny (2001, 2011) têm ressaltado ${ }^{19}$.

Nos papéis de Larrañaga, há um extrato da publicação Monthly Magazine de dezembro de 1806, p. 429, sobre as últimas observações dos naturalistas sobre os ossos fósseis e conchas, em que há menções ao Megatherium. Trechos sobre o envio do Megatherium pelo Marquês de Loreto, em 1789, e observações sobre os ossos que possuía em suas coleções, são reproduzidos nos trabalhos geológicos de Larrañaga e em seus Diários de História Natural, embora ele nunca tenha publicado o estudo mais completo, pelo qual Cuvier esperava. Em sua Memória geológica sobre la Piedra de cal de Buenos Aires por un hijo del país, embora as conchas fossem sua prioridade para os estudos estratigráficos, Larrañaga se permitiu contestar Cuvier, atribuindo couraça ao Megatherium a partir de detalhadas observações das ossadas de suas coleções: En parte alguna se ha encontrado nada más gigantesco ni extraordinario como el Megaterium de Cuvier, que se encontró en el Rio de Luxan, que ya ha perecido y solo tiene representante a nuestros

18 Carta de Mr. de Freycinet a Larrañaga, paris, 29/03/1822 (Larrañaga, 1923, 287-289).

19 Para uma discussão aprofundada sobre os debates em torno das classificações paleontológicas, do comércio de fósseis, do envio de coleções das regiões do Rio de La Plata aos Museus Europeus, ver entre os diversos trabalhos de Irina Podgorny - a quem agradecemos as inúmeras idéias trocadas sobre Larrañaga -, especialmente Podgorny (pre-print). 
Tatus, matacos, mulitas y quirquinchos. Aquel profundo maestro y fundador de la Anatomia comparativa me permitirá que me separe de su opinion en esta parte (Larrañaga, 1923: 23).

\section{Fronteiras}

Esses rápidos flashes da rede de correspondentes de Larrañaga e sua atuação têm o sentido de adensar nossos conhecimentos sobre os mecanismos de articulação, circulação de personagens e objetos, em um desses múltiplos pontos de intercâmbios e contatos, que foram as regiões de fronteiras móveis do sul da América nas primeiras décadas do século XIX. Buscam matizar tópicos sobre invisibilidades e isolamento de naturalistas, também nas regiões do sul da América. A ênfase em se tecer considerações sobre os lugares, onde se articulam os intercâmbios, pressupõe considerar a construção das ciências, no caso no início do século XIX, evidentemente inserida na geopolítica e nas tecnologias de informação e comunicação de mundos já bastante integrados. Larrañaga está longe de ter sido um coletor de amostras ou fornecedor de informações e coleções para centros científicos. Foi mais um, entre inúmeros, outros indivíduos que moldaram e organizaram seus imensos dados de acordo com seus próprios padrões de expertise, de conhecimento, servindo-se inclusive de suas condições sócio - políticas, culturais privilegiadas. É mais um caso, para as histórias das ciências local e historicamente contextualizadas, que buscam compreensões mais abrangentes e globalizadoras, e não se limitam há alguns poucos personagens protagônicos, para contribuir para o traçado de mapas simultaneamente mais densos em detalhes e abrangentes em dimensões, como sugere Lissa Roberts (2009). É também uma tentativa de aproximação de abordagens que contemplam o caráter especificamente local de encontros entre indivíduos situados nas redes globais cada vez mais amplas. Só ambos - o carater local e as redes globais - possibilitam e conferem significado quer as condições quer aos produtos resultantes desses encontros.

Delimitar fronteiras e cruzá-las nunca foi uma tarefa fácil, nos mais diferentes sentidos em que possamos imaginar. Situado estrategicamente em um território cobiçado, ocupado, perpassado pelos mais diferentes interesses, Larrañaga e seus correpondentes partilharam objetivos e construiram redes que mobilizaram diversos outros personagens além dos poucos mencionados aqui, fossem eclesiásticos, políticos, comerciantes, familiares, frequentemente tipos híbridos entre esses, 
que seria fácil identificarmos aos go-betweens, no sentido que lhes confere Simon Schaffer e outros autores (2010). Tais go-betweens não foram meros informantes ou simples agentes da unidirectional crosscultural diffusion, mas figuras que articularam relações entre mundos ou culturas diversas sendo capazes de circular entre eles. Personagens como Larrañaga, desempenharam papéis cruciais na promoção e estabelecimento de encontros e interações através de diferentes culturas e experiências científicas, mas cujas trajetórias foram largamente ignoradas na historiografia sobre a construção do mundo moderno, especialmente no domínio do conhecimento e das ciências. Penso esse ensaio, como uma contribuição ainda em construção, mas claramente inserida na já não tão recente historiografia voltada para as formas de conhecimento, expertise e mediação que esses ainda pouco conhecidos personagens construíram, desenvolveram e manipularam nas fronteiras que cruzaram. 


\section{Referências bibliográficas}

Algorta Camusso, R. El Padre Dámaso Antonio Larrañaga. Apuntes para su Biografía, Montevideo: Talleres Graficos A.Barreiro y Ramos. 1922

Camejo, L. "Larrañaga y la ciencia moderna". Fermentario, 2, 2008. http:// www.fermentario.fhuce.edu.uy/index.php/fermentario/article/ view/5

Castrillon, Alberto. Humboldt et la géographie des plantes. Revue des Histoires des Sciences.XLV/4,1992.p419-433.

Cuvier, Georges. Recherches sur les Ossemens Fossiles oú l'on rétablit. Les caractères de plusiers animaux dont les révolutions du globe ont détruit les espéces. Nouvelle Édition entièrement refondue, et considérablement augmentée. Tome cinquième, I ${ }^{\text {er }}$. Partie, contenant les rongeurs, les édentés, et les mammifères marins. Paris: chez G. Dufour et E. D'Ocagne, Libraires, et a Amestardam, chez les mémes, 1823.

Di Stefano, R. "Colegas clérigos del joven Darwin". Anuario del Instituto de Estudios Histórico. Sociales, (2010, no prelo).

Dwyer, John D. The Botanical Catalogues of Auguste De St. Hilaire. Annals of the Missouri Botanical Garden. Vol. 42, No. 2 (May, 1955), pp. 153-170.

URL: http://www.jstor.org/stable/2394600

Favaro, E. Dámaso Antonio Larrañaga. Su vida y su época. Montevideo: Impressora Rex S.A. 1950.

Furlong, S.J.G. Naturalistas argentinos durante la dominación hispánica. Buenos Aires: Editorial Huarpes. 1945.

Gonzáles, A. D. "Prologo", in: Favaro, E. Damaso Antonio Larrañaga. Su vida y su época. Montevideo: Impressora Rex S.A., 1950, VII-XIII.

Herter, G. Los dibujos de plantas de don Dámaso A. Larrañaga. Anales del Museo de Historia Natural de Montevideo (Segunda serie) 1928, pp. 409-426. 
Kury, L. B. "La politique des voyages en France au début du XIXe siècle et la culture scientifique de Auguste de Saint-Hilaire", in Laissus, Y. (eds.) Les naturalistes français en Amérique du Sud. XVIe-XIX siécles, Paris: C.T.H.S., 1995, pp. 235-245.

Larrañaga, D. A. Escritos de Don Dámaso Antonio Larrañaga, Instituto Historico Y Geográfico del Uruguay. Edición Nacional. Montevideo. Imprenta Nacional, 3 vols - 1922-1923.

Larrañaga, D. A "Correspondencia", in Larrañaga, D.A., Escritos de Don Dámaso Antonio Larrañaga. Instituto Historico y Geográfico del Uruguay. Edición Nacional. Montevideo. Imprenta Nacional, Tomo III, 1923, p.241-301.

Larrañaga, D. A. Memoria geológica sobre la reciente formación del Río de la Plata, deducida de sus conchas fósiles. In: Escritos de D. Dámaso Antonio Larrañaga. Instituto Histórico y Geográfico del Uruguay. Edición Nacional. Montevideo. Imprenta Nacional, tomo III, 1923, p. 7-20.

Larrañaga, D. A. Memoria geológica sobre la Piedra de cal de Bs. As. Por un hijo del pais. In: Escritos de Don Dámaso Antonio Larrañaga. Instituto Historico y Geográfico del Uruguay. Edición Nacional. Montevideo. Imprenta Nacional, 1923, t. III, p. 22-28.

Larrañaga, D. A. Oracion inaugural. Biblioteca de Montevideo. In: Escritos de D. Dámaso Antonio Larrañaga. Instituto Histórico y Geográfico del Uruguay. Edición Nacional. Montevideo. Imprenta Nacional, tomo III, 1924, p.136-146.

Lopes, M. M. O Brasil descobre a pesquisa cientifica: as ciências naturais e os museus no século XIX, Brasília, UnB, São Paulo, HUCITEC, $2^{\text {a }}$ ed. 2009, 1르 ed, 1997.

Lopes, M. M. Fósseis e Museus na Argentina e no Brasil, no século XIX: uma contribuição à história da Paleontologia na América Latina. Asclepio (Madrid), 1999 v. 22, n. 2, p. 145-164.

Lopes, M. M. e Podgorny, I. Caminos cruzados. El Museo Nacional de Historia Natural de Montevideo en la documentación del Museo Nacional de Buenos Aires. Ciencia Hoy, Buenos Aires, v.10, n.57, junio-julio, 2000. 
Lopes, M. M. e Varela, A. G. Viagens, tremores e conchas: aspectos da natureza da América em escritos de José Bonifácio de Andrada e Silva, José Hipólito Unanúe e Dámaso Antonio Larrañaga. Bol Museu Paraense Emilío Goeldi. Ciências Humanas, Belém, Pará v. 5, p. 227-242, 2010.

Pena, C. M. de. Introducción. In: Memoria geológica sobre la formación del Río de la Plata, deducida de sus conchas fósiles, escrita por los años 1819. Anales del Museo Nacional de Montevideo.Tomo I, p.VIIXLVII, 1897.

Podgorny, I. El camino de los fósiles: las colecciones de mamiferos pampeanos en los museos franceses e ingleses. Asclepio, (Madrid), 2001, v.53, n.2, p.97-116.

Podgorny, I. De ángeles, gigantes y megatérios. El intercambio de fósiles de las provincias del Plata en la primera mitad del siglo XIX. In: Ricardo Salvatore D. (comp.) Los lugares del saber. Contextos locales y redes transnacionales en la formación del conocimiento moderno. Rosario: Beatriz Viterbo Editora, 2007, p.125-157.

Podgorny, I. Traders from the past: Teodoro Vilardebó, Pedro de Angelis and the trade of bones and documents in the Río de la Plata, 18301850. Circumscribere: International Journal for the History of Science, Vol 9 (2011).

http://revistas.pucsp.br/index.php/circumhc/article/view/5272

Podgorny, I. Swallows, scraps of information, and cataphracts: How the genus Glyptodon, Owen, came to be in the 1830s. (pre-print).

Podgorny, I. e Lopes, M. M. El Desierto en una vitrina. Museos e historia natural en la Argentina, 1810-1890. México: Limusa. 2008.

Roberts, L. "Situating Science in Global History: Local Exchanges and Networks of Circulation", Itinerario 2009, 33:9-30. doi:10.1017/ S0165115300002680.

Rudwick, M. Bursting the Limits of Time. The Reconstruction of Geohistory in the Age of Revolution, Chicago: University of Chicago Press, 2005. 
Saint-Hilaire, (1887) A. de Viagem ao Rio Grande do Sul (1820-1821). Translated by Costa, A M. da. Originally published as Voyage a Rio Grande do Sul (Brésil). (Orleans : H. Herluison). Brasília: Senado Federal Cons. Editorial.

Saint-Hilaire, A. Aperçu d'un voyage dans l'intérieur du Brésil, la province Cisplatine et les missions dites du Paraguay. Paris. Imprimerie de A. Belin. 1823 http://www.brasiliana.usp.br/bbd/ handle/1918/01417800\#page/11/mode/1up.

Saint-Hilaire, A. de Histoire des plantes les plus remarquables du Brésil et du Paraguay. Paris: Imprimerie de A. Belin. 1824 http://catalogue. bnf.fr/ark:/12148/cb37267928g.

Schaffer, S.et al. (eds) The Brokered World Go-Betweens and Global Intelligence, 1770-1820. Uppsala Studies in History of Science, Volume 35, 2009.

Stephen Bell, A Life in Shadow: Aimé Bonpland in Southern South America, 1817-1858, Palo Alto: Stanford University Press, 2010.

Torrens, H.S. The early life and geological work of John Mawe, 17661829, and a note on his travels in Brazil. Buletin of the Peak District Mines Historical Society, 1992, 11 (6):267-271. 


\section{2.}

\section{Los pintores de la Real Expedición Botánica a Nueva España (1787-1803)}

Graciela Zamudio Varela ${ }^{1}$

\section{Reseña de la Expedición a Nueva España}

La Real Expedición a Nueva España (1787-1803) fue la última de las empresas botánicas que en el siglo XVIII organizara la corona española en sus colonias de ultramar. Tuvo entre sus objetivos llevar a cabo el inventario de los recursos naturales del virreinato, crear un Jardín Botánico y una Cátedra de Botánica en la capital novohispana. El equipo de exploración estuvo constituido por Martín de Sessé, director; José Longinos Martínez, naturalista; Juan Diego del Castillo, botánico y Vicente Cervantes, catedrático. A este equipo inicial, constituido por peninsulares, se agregarían como dibujantes los novohispanos Atanasio Echeverría y Juan de Dios Vicente de la Cerda, y con el nombramiento de botánico José Mariano Mociño.

Esta misión científica fue una empresa bien planeada que además de seleccionar en la metrópoli a sus miembros, estableció las teorías científicas, métodos, textos y reglamentos con los que se pondría en marcha. En el escenario colonial, contó con el apoyo económico y administrativo para que sus miembros pudieran recorrer durante 16 años grandes extensiones de las regiones tropicales del Nuevo Mundo.

La práctica científica de los miembros de la expedición tuvo como resultados la formación de una colección de miles de especímenes botánicos y zoológicos, numerosos manuscritos y varios cientos de dibujos de gran precisión artística y científica. Aunque es considerada como una de las empresas más importantes en la historia de la historia natural,

1 Historia y Filosofía de la Biología, Departamento de Biología Evolutiva, Ciudad Universitaria, México D.F., C.P. 04510. E-mail gzv@hp.fciencias.unam.mx 
fueron una serie de vicisitudes las que impidieron que se alcanzaran las luces perseguidas por sus hombres, tanto novohispanos como peninsulares. Baste comentar que la labor de estos naturalistas precedió a la gran aventura emprendida por Alejandro de Humboldt y Aimé Bonpland en territorio novohispano.

Al finalizar el tiempo destinado para la exploración científica algunos de sus miembros viajaron a España llevando consigo una de las colecciones más grande de objetos de historia natural, la mayoría nuevos para la ciencia de su tiempo. Sus protagonistas cruzaron el Atlántico con el anhelo de publicar la gran Flora Mexicana, sin embargo, una serie de sucesos políticos y económicos impidieron que este afán se llevara a cabo y los logros para la ciencia podrían haber quedado en el olvido a no ser porque numerosos investigadores de distintas disciplinas han mantenido vivo el interés en la empresa a través de los siglos transcurridos. Por ejemplo a lo largo del siglo XIX, y producto del intercambio de semillas que se hizo a través del Real Jardín Botánico de Madrid con instituciones botánicas de Europa, se tuvo conocimiento de la flora de regiones tropicales. Particularmente, al botánico suizo Augustin Pyramus de Candolle le sorprendió la exactitud de los dibujos que recreaban la riqueza de la flora americana, por lo que incluyó en su Prodromus systematis naturalis regni vegetabilis (1824-1873), 271 especies nuevas para la ciencia basadas en los dibujos de la expedición a Nueva España. Para el siglo XX, la colección de ejemplares de herbario fue prestada y enviada por tres décadas al Museo de Historia Natural de Chicago para su identificación taxonómica, tarea en la que participaron numerosos especialistas de esta institución. ${ }^{2}$ Asimismo, se publicaron diversas obras que muestran la diversidad de disciplinas abordadas a lo largo de esta empresa científica. ${ }^{3}$ En la década que va del Siglo XXI, continúan los estudios que analizan sus contribuciones a la historia natural. ${ }^{4}$

2 McVaugh, R. 2000, Botanical results of the Sessé \& Mociño expedition (1787-1803). VII. A guide to relevant scientific names of plants, Hunt Institute for Botanical Documentation, University, Pittsburgh.

3 Lozoya X. 1984, Plantas y luces en México, Serbal, Barcelona; B. Sánchez, M.A. Puig-Samper y J. de la Sota (eds.), 1987, La Real Expedición Botánica a Nueva España (1787-1803), V Centenario - Real Jardín Botánico, Madrid; Maldonado, J.L. 1996, Flora de Guatemala de José Mociño, Aranjuez, Doce Calles/CSIC-Madrid; Blanco, P.; M.A. Puig-Samper; G. Zamudio; M. Valero y J.L. Maldonado, 2000, La exploración botánica de las islas de barlovento. Cuba y Puerto Rico, siglo XVIII, Editorial Doce Calles/ CSIC-Madrid, 526 pp.; Zamudio, G. 2000, Catálogo de los dibujos de la Real Expedición Botánica del Archivo del Real Jardín Botánico de Madrid, en El Águila y el Nopal. La Expedición de Sessé y Mociño a Nueva España, CSIC-Real Jardín Botánico, Madrid, pp. 117-212.

4 Navarro, A.; T. Peterson; M.A. Puig-Samper and G. Zamudio, 2007, The ornithology of the Real Expedición Botánica a Nueva España (1787-1803): an analysis of the manuscripts of José Mariano 
En cuanto al peregrinar que siguieron las colecciones de objetos de la historia natural novohispana, para esta contribución solo abordaremos lo relacionado con el destino de las aproximadamente 2000 ilustraciones científicas. Al respecto señalamos que la última noticia que se tenía sobre ellas era la de 1820, año de la muerte de José Mariano Mociño (1757-1820) quién las mantenía en su poder junto con algunos manuscritos y ejemplares de herbario. De este tesoro natural americano que pasó a manos del médico que asistió al naturalista criollo en Barcelona, España, se desconoció su paradero hasta que en 1979 fueron localizados en una biblioteca particular de esa ciudad, y adquirida en 1981 por el Hunt Institute for Botanical Documentation, en Pittsburgh, Estados Unidos. En 2010 esta institución norteamericana otorgó los derechos, gracias al interés de la Editorial Siglo XXI y de la Universidad Nacional Autónoma de México, para que los dibujos fueran estudiados por especialistas y publicados en 12 volúmenes.

\section{Dibujos y colonialismo científico}

La descripción y nomenclatura de las especies "descubiertas" a lo largo de los trabajos de exploración se llevó a cabo utilizando el sistema de clasificación propuesto por el naturalista sueco Carl von Linné (1707-1778), cuya filosofía influyó de manera determinante en el arte botánico de finales del siglo XVIII. Es importante señalar que existió una relación entre lo representado en las ilustraciones botánicas, modeladas por el sistema linneano, y los objetivos de la empresa colonialista dirigida a catalogar las especies nuevas registradas durante los viajes de exploración. Así, el artista dirigió especial atención hacia las estructuras sexuales de la flor que Linneo había designado como las centrales para seguir su sistema de clasificación, es decir, los estambres y los pistilos. Un dibujo que representara adecuadamente estas estructuras fue la base para la clasificación taxonómica de las especies "nuevas" que documentaban los viajeros naturalistas. Sobre los artistas y la iconografía que produjeron a finales del siglo XVIII, trataremos a continuación.

Mociño, The Condor, 109: 809-824; Blanco, P.; M.A. Espejo y A.R. López, 2010, El Herbario de la Real Expedición Botánica de Nueva España (1787-1803), Real Jardín Botánico-CSIC, Madrid, 687 pp. 


\section{Los pintores en acción}

En relación al papel que desempeñaron los dibujantes en las tareas de exploración, este se señala en la Orden Real de creación de la Expedición expedida por Carlos III en octubre de 1786, en la que se establece que:

"...se examinen, dibujen y descrivan metodicamente las producciones naturales de mis Fertiles Dominios de Nueva España... con el objeto general, e importante de promover los progresos de las ciencias Phisicas, desterrar las dudas, y adulteraciones que hay en la medicina, tintura y otras artes útiles que aumentan el comercio ..." ${ }^{\text {" }}$

Sobre el proceso de selección de los dibujantes realizado entre los estudiantes de la Escuela de Artes de San Carlos, ${ }^{6}$ Sessé informó a Madrid lo siguiente:

"Se han nombrado, con mi propuesta y la del Director de la Academia, por Dibujantes de la Expedición a Dn. Vicente Cerda y Dn. Atanasio Echaverria [sic], con el sueldo de 1000 ps. viajando, y 500 en la Capital. Ambos son de havilidad, pero el segundo excede en mucho á Cerda; [Echeverría] ...que en el mismo dia acabo quatro plantas y una mariposa que ha encantado á este Sr. exmo. pues parece que quiere escapar del papel. La humildad de ambos es tan recomendable como su ingenio y nos augura una paz sin interrupción en todo el viaje."

Hasta ahora son pocos los datos biográficos con los contamos sobre Vicente de la Cerda y Atanasio Echeverría que nació alrededor de 1773 ya que tenía 15 años cuando se incorpora a la Expedición, y quien a principios del siglo XIX viajará a España en donde será nombrado dibujante de la corte. De lo que tenemos más noticias es de su desempeño como artistas durante los 16 años que duró la empresa en territorio americano, por ejemplo cuando de la Cerda comunica al virrey que:

"...el adjunto Memorial es cierto haviendo salido diversas veces en su compañía [de Sessé] á recoger,

5 Archivo General de la Nación-México (en adelante AGNM), Historia, vol. 527, exp. 14, fs. 42-43.

6 La Real Academia de San Carlos había sido creada en 1782, a semejanza de la Real Academia de Bellas Artes de San Fernando de Madrid.

7 Archivo del Real Jardín Botánico de Madrid, V, 1, 1, 23, fs. 2v-3. 
describir, y dibujar quantos vegetales así nuevos como conocidos por otros autores, se producen en las cercanías de México y demás lugares citados por el referido Director; ....según se nos prebiene por las Instrucciones..."

\section{Entrenamiento de los artistas}

La construcción de las ilustraciones según las normas establecidas en la metrópoli, requirió de una capacitación adecuada brindada en instituciones académicas cuyos programas de estudios contemplaban la representación artística de los elementos de la naturaleza. En la Nueva España esta función la desempeñó la Real Academia de San Carlos, creada en 1782 apenas unos años antes del arribo de los expedicionarios y en la cual se formaron los dibujantes de esta empresa.

Una vez incorporados oficialmente, los dibujantes estuvieron obligados a cumplir exactamente los puntos que abrazaba la Instrucción que deberán observar los dos Delineadores o Dibujantes que de orden de S.M. han de servir con el ejercicio de su profesión en la expedición de Botánica, e Historia Natural de Nueva España. ${ }^{9}$ Interesa destacar lo establecido en algunos artículos de este reglamento ya que nos permite conocer cómo fue normada la práctica artística cuyos resultados se observan en las ilustraciones. Así, el primer artículo inicia señalando un aspecto fundamental: que los "Artistas se han de ceñir a copiar exactamente la Naturaleza en sus producciones, sin pretender adornarla, ni añadir cosa alguna de su imaginación ... ${ }^{10}$ es decir, se les exigía realismo en sus representaciones.

Asimismo, las Instrucciones para los dibujantes son muy claras en cuanto a las normas que deberían acatar para la construcción de las especies a ilustrar, la mayoría nuevas para la ciencia. En general, en el centro de la hoja de papel se representó un trozo de la planta portando tallo, hojas, flores y frutos, y en uno de los extremos de forma esquemática se incluye la "anatomía" de las estructuras esenciales de la flor y el fruto, indispensables para seguir la clasificación linneana. Lo anterior debía realizarse mientras se conservaran "frescas" las plantas,

8 AGNM, Historia, vol. 462, exp. 1, fs. 7 y $7 \mathrm{v}$.

9 AGNM, Reales Cédulas, vol. 138, exp. 189, fs. 310-313.

10 AGNM, Reales Cédulas, vol. 138, exp. 189, f. 310. 
debido a que algunas de las características se perdían al desecarse (Art. $\left.2^{\circ}\right) .{ }^{11}$ Una vez realizado el dibujo, la construcción iconográfica de la especie adquiría permanencia, al menos en el papel tipo holandés en el que había sido plasmada, algo que no sucedía con los ejemplares de herbario ya que durante el proceso de secado la morfología de sus estructuras se transformaba drásticamente, cambiaban los colores originales y su fragilidad disminuía el tiempo de utilidad taxonómica, además de que los dibujos se transportaban más fácilmente y ocupaban menos espacio. Por lo anterior, las colecciones de dibujos de plantas y animales del Nuevo Mundo que se trasladaron a Europa fueron consideradas como verdaderos botines realizados por los comisionados para esta empresa artística.

A continuación se incluye el artículo $4^{\circ}$ que en parte describe la práctica que normó la participación de los dibujantes a lo largo de la exploración científica que abarcó regiones que van de Nutka [Canadá] a Costa Rica, además de las islas de Cuba y Puerto Rico:

"En cuanto al uso de los colores, como el fin es aprovechar el tiempo de la expedición lo más que se pueda siguiendo a los Botánicos, y Naturalistas en sus operaciones, se contentarán con iluminar aquellos Cuerpos Naturales que por su Especial hermosura, y por lo vistoso, extraño de sus matices, lo merezcan, ciñéndose aún en este caso a representar en las plantas una flor, un fruto, y generalmente una parte de cada especie, dejando las demás de Tinta de China, para iluminarlas a la vuelta a España a imitación de aquellas." ${ }^{12}$

Así, hay ilustraciones que nos acercan al método de trabajo de los artistas como aquellas en las que en una misma hoja están representados varios detalles florales correspondientes a diferentes familias, con anotaciones útiles para el dibujante que concluiría la representación iconográfica de la especie. En cuanto al trabajo de campo Sessé programaba las excursiones tomando en cuenta las estaciones más oportunas, preferentemente la primavera "... por ser en la que casi todas las plantas florecen y se dexan examinar científicamente."13 Las excursiones, además de "descubrir" nuevas especies, permitieron a los delineado-

11 AGNM, Reales Cédulas, vol. 138, exp. 189, f. 310v.

12 AGNM, Reales Cédulas, vol. 138, exp. 189, f. 311.

13 AGNM, Historia, vol. 461 exp. 7, f. 51. 
res rectificar o completar algunos detalles de las ilustraciones que en "peregrinaciones" anteriores por no encontrarse con flores habían quedado en bosquejos. ${ }^{14}$ El trabajo de campo no estuvo libre de dificultades para los dibujantes como lo informó Sessé desde la Habana, Cuba:

\footnotetext{
"...la furia de las aguas, y una epidemia de tercianas continuas, de que rara vez se libra aquella Ciudad por estos meses, y de que fueron atacados no sin algún peligro Dn. Jaime Senseve y el pintor Echeverría, nos impidieron salir a recorrer los campos hasta fines de septiembre." ${ }^{15}$
}

Para poner en marcha las Instrucciones, los dibujantes contaron con materiales como "Tres caxitas en las que van las Brochas, Pinceles, Laca, Tinta de china, Ultramar, Pomitos de azogue, y vidrio para la sal de Tártaro... seis resmas de Papel de Holanda para los Dibujos de Plantas, y Animales de la marca de la muestra que lleva a este efecto el Catedrático Dn. Vicente Cervantes ...", los cuales fueron adquiridos en Madrid el 12 de Mayo de $1787 .{ }^{16}$

En la mayoría de las ilustraciones botánicas de la Expedición a Nueva España, la especie se encuentra representada por el tallo, las hojas, en algunas la raíz, así como las flores y los frutos en distintos grados de desarrollo. En cuanto a los detalles de las estructuras reproductoras, y he aquí la influencia linneana, generalmente se encuentran en la parte superior izquierda, esquematizadas mediante la disección de la flor destacando de los estambres su número y posición respecto a los pétalos; el número de pistilos; de los pétalos, si están libres o unidos, lo mismo que para el cáliz. En algunas láminas se incluye una disección transversal del fruto con algunas semillas al lado. Todo lo anterior dibujado sobre un fondo blanco en donde son notorias las sombras de la representación de las estructuras sexuales. Esta descripción llevaría a dar por hecho que los dibujantes contaron con ejemplares ideales, es decir, que los comisionados colectaron durante sus exploraciones especímenes completos, es decir, con estructuras vegetativas y reproductivas en la misma planta algo que es poco probable, por lo que debieron haber colectado la misma especie en diferentes etapas de desarrollo en diferentes localidades.

14 AGNM, Historia, vol. 462, exp. 1, f. 8.

15 AGNM, Historia, vol. 461, exp. 7, f. 51v.

16 AGNM, Historia, vol. 527, exp. 2, fs. 3-4. 
En general este es el tipo de ilustraciones producidas por los pintores de las expediciones científicas en ultramar, representaciones iconográficas en las que por instrucciones metropolitanas quedaban eliminados tanto el contexto cultural como el ecológico en el que se desarrollaron las especies representadas. Sin embargo, la revisión de la obra iconográfica de la naturaleza novohispana realizada bajo otra mirada, es decir, no solo aquella que se dirige hacia los detalles de la flor y que de manera natural y rápida nos conduce a la clase linneana a la que pertenece la especie observada, permitió un acercamiento a una diversidad de elementos, algunos de los cuales se señalan a partir de la selección de dos de las ilustraciones de la colección Torner antes mencionada. La primera nos brindan información sobre los conocimientos útiles que tenían los habitantes sobre las plantas, seguida de un ejemplo en el que fue representado el ambiente ecológico en el que crecía una ave.

\section{Ilustraciones y contexto cultural}

Uno de los objetivos que se persiguieron con la creación de la Real Expedición Botánica fue el llevar a cabo el registro de los usos tradicionales probados por los habitantes originarios de la Nueva España, dentro de los cuales los medicinales tuvieron prioridad. Esta información no solo quedó registrada en los manuscritos ya que también contamos con numerosas ilustraciones en las que se hicieron anotaciones sobre las aplicaciones médicas locales, así como el nombre indígena con el que se conocía la planta. Para este último dato, los comisionados tuvieron a la mano la obra del médico Francisco Hernández, quien había explorado el centro del virreinato novohispano entre 1571 y $1577 .{ }^{17}$

A manera de ejemplo se incorpora la ilustración número 1091 de la colección Torner, cuyo marco encierra un ejemplar botánico completo, es decir, raíz, tallo, hojas, flores y fruto, así como detalles de los estambres, pistilos y corola, incluida la sombra que proyectaban estos sobre el papel. En la base de la imagen se anotó el nombre científico de la planta, según Linneo Agave americana Linn., con lo cual la especie quedaba ubicada en el sistema universal de clasificación botánica. ${ }^{18}$ Abajo del

17 Hernández, F. 1790. Opera cum edita, tum inedita, Casimiro Gómez Ortega, Madrid, España, 3 vols.

18 Para llevar a cabo su práctica naturalista, los miembros de la Expedición contaron con libros enviados de Madrid el 21 de junio de 1788. En el listado se encuentran los publicados por Carlos Linneo, como el titulado "Linnaei Species Plantarum, Editio tertia Vindobonae 1764. 2 tomos en 8. pasta, echos venir de Barcelona. 74 pesos." Manuscrito núm. 487 de la obra de Calatayud, M. A., Catálogo de las expediciones y viajes científicos españoles siglos XVIII y XIX, CSIC, Madrid, 1984. 
nombre linneano se trazó el nombre indígena Metl seu Maguei, tomado de la página 270 de la obra de Francisco Hernández. Pero el aspecto que más nos interesa destacar en esta lámina es el texto incluido que hace referencia a las propiedades medicinales y económicas de esta especie, entre las últimas se encuentra su uso tradicional como bebida alcohólica llamada pulque. (Figura 1)

\section{Ilustraciones y contexto ecológico}

A manera de ejemplo tomamos la ilustración número 0303 de la colección Torner correspondiente a una ave acuática que fue representada en el ambiente ecológico propio de los lagos cercanos a la capital novohispana, en donde se destaca la vegetación propia del lugar, y en el extremo superior izquierdo el detalle anatómico de la lengua del ave. En cuanto a la clasificación taxonómica, la anotación $S p$. N. indica que el espécimen ilustrado fue inicialmente considerado como nuevo para la ciencia ornitológica, asignándole los naturalistas el nombre específico de mexicana, cambiada después a Nycticorax al ubicarla en la página 235 de la obra de Linneo, y cuyo nombre es aceptado actualmente por los especialistas. (Figura 2)

Así, las ilustraciones de la Expedición a Nueva España no solo nos brindan información sobre la ubicación de la especie en la clasificación linneana, sino también sobre sus relaciones ecológicas o culturales, lo cual, si bien se alejaba de lo establecido en las instrucciones enviadas para el desempeño de los dibujantes, seguramente esta información se incluyó por orden de los otros comisionados como resultado de la experiencia de campo recabada.

Otro papel que han jugado los dibujos, en parte debido al peregrinar ${ }^{19}$ de que han sido objeto, es el de haber sido asignados como ejemplares "tipo" al nombrar, según el código de nomenclatura, una especie nueva para la ciencia de la que se carecía el ejemplar de herbario.

Resulta interesante comentar que los objetos de historia natural reunidos por los expedicionarios a lo largo de distantes y riesgosos viajes, cumplieron también una función local, la de ser exhibidos ante un público que se maravillaba de ver reunida una naturaleza en parte conocida y en parte exótica, aspecto del que nos enteramos por el siguiente

19 Feliz término utilizado por René Grobet Palacio, en El peregrinar de las flores mexicanas, 1982. INIREB, CECSA, México. 
comentario de Sessé: " ...muchas plantas, que desecadas y dibuxadas presenta [Cervantes] a las Gentes que acuden a su oficina a satisfacer, ó su buen deseo ó su curiosidad..."20

Finalmente, lo que nos ha interesado destacar de las ilustraciones científicas como uno de los resultados de los trabajos de la Expedición a Nueva España, es precisamente que en ellas se combinaron las dos tradiciones culturales, la científica universal y la indígena local.

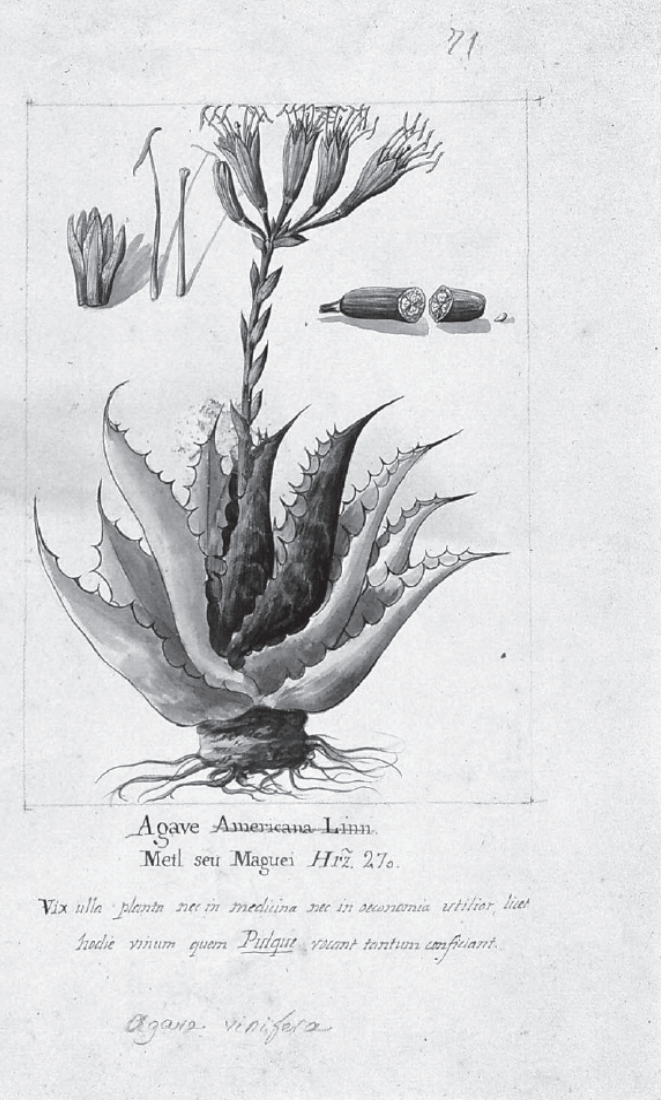

Figura 1. Agave americana L. Dibujo número 1091 de las Ilustraciones biológicas de Sessé \& Mociño, en la Colección Torner. Representación de las estructuras sexuales de la flor, el nombre científico linneano y el nombre náhuatl recogido por Francisco Hernández en el siglo XVI. En latín los usos medicinales y económicos de la especie.

20 AGNM, Historia, vol. 462, exp. 1, f. 5v. 


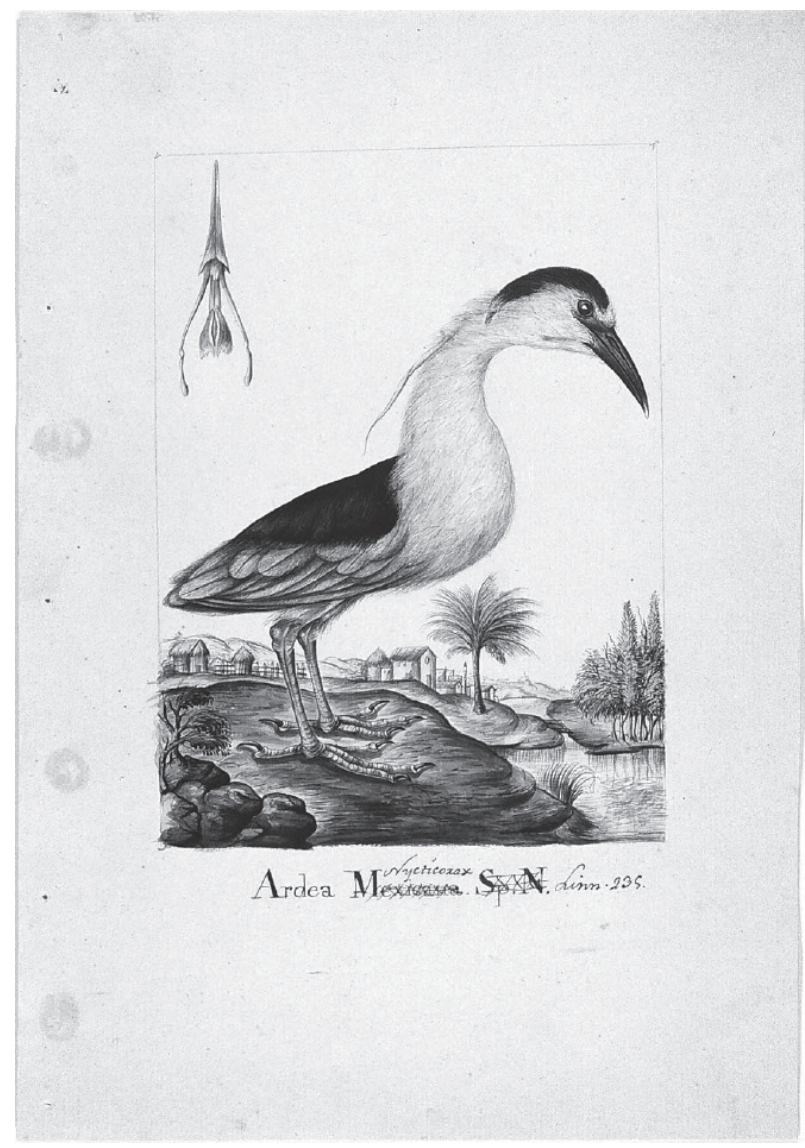

Figura 2. Ardea nycticorax L. Dibujo número 0303 de las Ilustraciones biológicas de Sessé \& Mociño, en la Colección Torner. Representación del ambiente ecológico propio de la especie; detalle anatómico de la lengua y anotaciones sobre la clasificación taxonómica según Carlos Linneo. 


\section{Perspectiva histórica da evolução do conceito de museu em Portugal}

João Brigola ${ }^{1}$

acto humano de coleccionar objectos - aos quais é retirado valor de uso e atribuído, em contrapartida, valor simbólico - constitui, em si mesmo, o fundamento antropológico da atitude museológica. Uma vez integrado numa colecção, o objecto, subtraído à usura física e investido de significações, proporciona contemplação, deleite e estudo. A história do coleccionismo tem identificado os mais diversificados testemunhos desta actividade, presente no território da península Ibérica desde, pelo menos, a cultura megalítica.

Tem sido possível documentar a existência de colecções, desde a fundação da nacionalidade e ao longo de todo o período medieval, através de inventários e de testamentos da Casa Real e da nobreza, assim como dos bens da Igreja, em mosteiros, conventos, catedrais, igrejas de peregrinação, paróquias, ermidas e capelas. Provenientes de instituições religiosas, muitos destes bens artísticos, arqueológicos e científicos, considerados entesouramento sagrado, persistiram até aos nossos dias protegidos pelo apego comunitário das populações, caso dos tesouros das Sés de Braga, Coimbra e Évora.

O Renascimento conheceu a formação de colecções recolhidas pelos humanistas, cujo inventário geralmente associava a classificação e a datação como elementos descritivos. Os coleccionadores deste período histórico - príncipes da Igreja e do Estado, e eruditos - interessaram-se sobremaneira pela recolha de especímenes arqueológicos, epigráficos, numismáticos, artísticos, naturais e científicos. As mais

1 Professor Universitário. Historiador e Museólogo. Director Geral do Instituto dos Museus e da Conservação, Ministério da Cultura de Portugal. 
famosas iniciativas museológicas deste período devem-se ao 1 을 Duque de Bragança, D. Afonso, a D. Pedro de Avis, ao Arcebispo de Braga D. Diogo de Sousa, a André de Resende, a D. João de Castro, a António de Gouveia, a Damião de Góis, e a Garcia de Orta. Também o Paço Real da Ribeira, ao tempo de D. Manuel, albergou uma rica recolha de naturalia e artificialia provenientes dos novos mundos. Já em meados do séc. XVII, a par de pinacotecas existentes em casas nobres e religiosas, destaca-se D. Luís de Menezes, 3 o Conde da Ericeira, autor do Portugal Restaurado, que iniciou, no Palácio da Anunciada, em Lisboa, um Gabinete de curiosidades naturais, bem como uma biblioteca que chegou a possuir mais de quinze mil volumes e que se achava ornamentada com globos, instrumentos matemáticos e colecções de antiguidades e de numismática.

$O$ reinado de $D$. João $V$ representou, no campo museológico, tal como nos domínios da cultura e da ciência, uma tentativa de acerto com o passo europeu. O monarca instituiu, em 1720, a Academia Real da História Portuguesa e, no ano seguinte, através do Alvará sobre a conservação de monumentos antigos, atribuiu aos académicos e aos sócios correspondentes a missão de salvaguarda do património edificado e, sobretudo, a dos bens culturais móveis. Desta actividade resultaria a recolha de grande número de objectos arqueológicos em mármore e em vários metais, descobertos em escavações casuais em diversas partes do país. Com esses objectos formou-se, no edifício do Paço dos Duques de Bragança, aquilo que José Leite de Vasconcelos designou de "primeiro museu nacional de arqueologia". As iniciativas da Coroa, e de eruditos, de aristocratas e de clérigos, de acordo com as características dominantes no coleccionismo barroco, dirigiram-se igualmente para as obras de arte em geral, para as pinturas em particular e, sobretudo, para a numismática e a medalhística. Também é possível documentar o interesse pela aquisição de especímenes da natureza, bem como a permanência da cultura da curiosidade, o acumular desordenado de objectos maravilhosos: as naturalia e as mirabilia. Destes objectos armazenados em gabinetes de erudição curiosa e em galerias de arte pouco restou, além da sua memória arquivística, devido à completa devastação ocorrida em 1755 do Paço Real da Ribeira e do Paço dos Duques de Bragança, ao Chiado, bem como de inúmeros palácios e conventos de Lisboa, entre os quais deve ser destacado o Palácio da Anunciada, propriedade de D. Francisco Xavier de Menezes, 4을 Conde da Ericeira.

Com o modelo pombalino de Ilustração, entendido à luz da teoria política do Absolutismo Esclarecido, ganharam vigor as iniciativas estatais: os museus de história natural e jardins botânicos da Ajuda (1768) e os da Universidade de Coimbra (1772). A educação filosófica do Príncipe 
e a reforma da universidade explicam a urgência do ensino e difusão das ciências físicas e naturais. A observação directa dos seres e dos objectos e o experimentalismo como metodologia educativa impuseram a construção de equipamentos museológicos, tomando nova dimensão o próprio conceito de Museu. Alargaram-se os públicos e abriram-se portas num dia fixo da semana; sofisticaram-se os equipamentos - livraria, casa do risco, laboratório, salas de preparação, armazém; contrataram-se especialistas estrangeiros e funcionários permanentes; organizaramse expedições científicas aos territórios continental e ultramarinos (as Viagens Philosophicas) e envolveu-se a nossa diplomacia na rede internacional de aquisições.

No período pós-pombalino adquiriu impressionante vitalidade $\circ$ coleccionismo privado de cariz não exclusivamente, mas dominantemente, naturalista: os gabinetes de aristocratas e de eruditos (Angeja, de Visme, Balsemão, Vasconcelos, Cáceres, Araújo, Rey e Sampaio); os gabinetes de eclesiásticos (Caetano do Bem, José Mayne, Manuel do Cenáculo); os gabinetes de medalhas e antiguidades (Vidal da Costa e Sousa e o da Livraria Pública). Contudo, para os finais da centúria de setecentos, parece instalar-se a consciência de que a designação de 'Museu' se devia reservar para iniciativas que envolvessem uma dimensão - e uma ambição - que superassem a realidade mais chã do vulgar coleccionismo privado de amadores e eruditos. A 'Museu' passou-se a associar um espaço de exibição fisicamente mais vasto, dotado de um quadro de profissionais, e assumindo obrigações permanentes para com o público. Ou seja, a designação 'Gabinete' passava a reflectir a realidade de um coleccionismo de particulares que não cumpria, genericamente, o triplo alcance público, permanente e profissional das colecções suportadas pelo Real Erário (Ajuda e Coimbra) ou dos casos excepcionais dos «museus» do padre-mestre Mayne e do arcebispo Cenáculo, libertos das contigências desagregadoras dos patrimónios familiares.

Já com a sociedade liberal, factores históricos (implantação do constitucionalismo, extinção dos conventos e nacionalização dos bens da Igreja) e a adopção de novos valores culturais (exaltação da história nacional, gosto romântico, conceito de monumento histórico-artístico) conjugaram-se na emergência de novas realizações museológicas que traduziam mudanças na natureza das colecções. De par com os objectos da história natural e dos artefactos etnográficos - recolhidos nos museus da Ajuda, da Universidade, da Academia das Ciências, na Escola Politécnica de Lisboa e na Academia Politécnica do Porto - insinuava-se, com autonomia museal, o objecto artístico e o arqueológico. O período da monarquia constitucional - cujas balizas cronológicas 
correspondem à criação do Museu Portuense (1833) e à do Museu dos Coches (1905) - conheceu um florescente movimento de abertura de instituições museológicas por todo o país, rompendo-se com a acentuada macrocefalia das épocas anteriores, e evidenciando uma concepção de 'Museu' enquanto centro de estudo, inventário e catalogação de colecções. As colecções artísticas assumiram um papel central nas preocupações museológicas de particulares (galerias de João Allen, Pedro Daupias, Monteiro de Carvalho, Alfredo Keil, do rei D. Luís), do Estado (Museu Real de Bellas Artes e Archeologia, às Janelas Verdes, e Museu da Academia de Belas Artes do Porto, no Convento de S. António) e da Igreja (Museu de Arte Sacra, na Sé Nova de Coimbra). Também radica neste período a génese de três instituições da museologia aplicada às Ciências da Natureza: o Jardim Botânico da Escola Politécnica de Lisboa, o Jardim Zoológico e de Aclimatação de Lisboa e o Aquário Vasco da Gama. Outras importantes iniciativas museológicas de cariz artístico, histórico, arqueológico, etnográfico e científico, cuja influência se prolongou até aos nossos dias, ficaram a dever-se, entre outros, a Possidónio da Silva, a Martins Sarmento, a Santos Rocha, a António Augusto Gonçalves, a Francisco Tavares Proença Júnior, à instituição militar com o Museu de Artilharia, aos Serviços Geológicos, à Sociedade de Geografia de Lisboa, e, sobretudo, à acção teórica e pedagógica de José Leite de Vasconcelos.

Com a implantação da República foi reforçada a vontade política e legal de dar corpo e coerência a uma rede de museus nacionais e regionais, de acordo com uma visão pedagógica, patrimonial e artística que se queria essencialmente divulgadora e descentralizadora. Entre 1912 e 1924 criaram-se treze museus regionais (de arte, arqueologia, história e numismática), ainda que quase todos derivados de iniciativas já conhecidas no período anterior. Criaram-se dois museus nacionais (o de Arte Antiga e o de Arte Contemporânea), assim como museus de tipologia inovadora: Museu da Cidade de Lisboa, Museu Escola João de Deus, Museu Antoniano e várias casas-museu, nomeadamente a Casa dos Patudos de Alpiarça, concebida pelo arquitecto Raúl Lino para albergar a colecção de arte de José Relvas e aberta ao público depois da sua morte. O Museu dos Coches, criado em 1905 por iniciativa da rainha D. Amélia, foi elevado em 1911 à categoria de museu nacional.

O quadro museológico do Estado Novo, desde os anos trinta até aos anos sessenta, tem que ser encarado à luz dos princípios ideológicos do regime, nomeadamente o do restauro interpretativo do património edificado e o do comemorativismo nacionalista. É neste contexto que surgiram iniciativas como a instalação, no Porto, do Museu Nacional 
Soares dos Reis, o lançamento de um plano de museus regionais etnográficos, e as actividades museológicas associadas às Comemorações Centenárias (1940), de que é exemplo o Museu de Arte Popular (1948). Em inquérito realizado nos anos trinta, pelo Museu Nacional de Arte Antiga, identificavam-se três museus nacionais, sete regionais e outros trinta e três espalhados pelo País, dos quais vinte e dois dependentes das Câmaras Municipais, dois de Comissões de Iniciativa e Turismo, dois pertencentes às Juntas Gerais dos Distritos, dois ligados a Misericórdias, três particulares e, ainda, o Museu da Casa de Nazareth e o Museu Camiliano. No decorrer da década de quarenta merece particular relevo por ter constituído à época facto inédito na história dos museus portugueses a instalação do Museu José Malhoa, das Caldas da Rainha, em edifício construído de raiz. A partir da década de sessenta factores vários de ordem interna e externa proporcionaram novas visões patrimoniais e museológicas, quer em termos legislativos (Decreto 46758), quer associativos (Associação Portuguesa de Museologia, criada em 1965), quer mesmo de novas propostas museais, de que é exemplo cimeiro a inauguração do Museu de Calouste Gulbenkian (1969). É neste contexto que é organizado e programado o Museu de Etnologia do Ultramar que, apesar de datar de Março de 1965 o decreto que o criou e lhe fixou o estatuto, só viria a abrir as suas portas ao público depois da Revolução de 25 de Abril, passando as denominar-se Museu Nacional de Etnologia.

Com o regime democrático fundado em 1974, assistiu-se a um renovado interesse pelo património natural e cultural, que, por um lado, originou a protecção e musealização de numerosos sectores da paisagem portuguesa e, por outro, veio a culminar numa verdadeira explosão museal, para a qual contribuiu sobremaneira a iniciativa comunitária de populações e de autarquias locais. Deste movimento haveria de resultar o fenómeno da 'municipalização' do universo museológico já que, na verdade, as administrações regionais e locais (regiões autónomas, assembleias distritais, câmaras municipais, e juntas de freguesia) tutelam hoje um segmento significativo dos museus existentes no País. Novas tipologias nascidas a partir de experiências museológicas nitidamente inspiradas nas linhas doutrinais da chamada Nova Museologia e marcadas por um conceito mais abrangente de património - associado aos conceitos de cultura material, comunidade, território e identidade caracterizaram essencialmente as décadas de oitenta e noventa. É neste contexto que deve ser assinalado a criação, em Lisboa, do Movimento Internacional por uma Nova Museologia (MINOM, 1985), assim como o movimento de revalorização do património natural, científico e técnicoindustrial, o qual foi acompanhado pelo exemplar protagonismo das 
universidades e, também, de muitas empresas na salvaguarda dos patrimónios edificado, móvel e documental provenientes da sua actividade profissional. Experiências museologica e socialmente mais inovadoras valeram a museus portugueses prémios internacionais, nomeadamente o de Museu Europeu do Ano, no âmbito do Conselho da Europa, a partir de 1978. Entretanto, o País passou a ser regularmente confrontado com a responsabilidade de organizar grandes eventos internacionais de incidência cultural, os quais têm genericamente constituído estimulantes experiências no campo museológico e museográfico e proporcionado a abertura de novos espaços expositivos, tais como a XVII Exposição de Arte, Ciência e Cultura (Conselho da Europa, 1983), Europália (1991), Centro Cultural de Belém (1992), Lisboa Capital Europeia da Cultura (1994), Exposição Mundial de Lisboa (1998), Porto Capital Europeia da Cultura (2001), sem esquecer a acção notável e constante, a esse nível, da Comissão dos Descobrimentos, de 1992 a 2002. Os últimos anos têm também sido marcados pela pulverização de iniciativas de índole museológica de qualidade por vezes muito desigual. Esta situação, decorre, em grande medida, de uma intencionalidade inerente ao conceito de "museu-âncora" - instrumento ao serviço do desenvolvimento de populações e de territórios carenciados. Se há traço que caracterize o panorama museológico lusitano é o da necessidade de consolidação de experiências qualificadas ao invés da expansão de novos espaços museais sem capacidade de sustentabilidade futura. 


\section{Las rutas del saber. El tráfico de manuscritos iberoamericanos en la primera mitad del siglo XIX}

Irina Podgorny ${ }^{1}$

En la historiografía de la arqueología americana se afirma frecuentemente que los métodos de investigación del siglo XX están marcados por una tendencia filológica y otra naturalista. Mientras la primera caracterizaría el quehacer de los llamados sabios de gabinete, ligados al espacio del escritorio y de la biblioteca, la segunda surgiría de los viajes y de las observaciones en el campo. Ese esquema implica también transformar la pesquisa a través de los documentos en una etapa ligada al pasado de la disciplina.

Este trabajo argumenta que esta manera de acercarse a la historia oculta las prácticas y los actores de la investigación decimonónica, es decir, esas rutinas y protocolos de los funcionarios, ingenieros geógrafos, tipógrafos, diplomáticos y comerciantes que van a modelar el trabajo de quienes se interesaron por el pasado local. Estos protocolos, a su vez, generaron un tipo de saber determinado, condicionado por el tráfico de documentos producidos por la administración colonial. Varios autores han señalado que la emergencia de la arqueología americana se vincula con la colección, transcripción y copias de manuscritos (Ballestero Gaibrois 1960, Crespo 2008, García Sáiz 1994, Podgorny 2011). Sin embargo, no todos recuerdan que los viajeros no salían de sus casas sin una biblioteca de referencia que los acompañara Viajar también significaba visitar las colecciones locales, los museos y los archivos para comprar, copiar, encargar copias, hacer extractos o, aún más fácil, robar los manuscritos que allí se localizaran (cf. Bourguet 2010). Para entender este argumento

1 Museo de La Plata - Investigadora Independiente del CONICET E-mail: podgorny@retina.ar 
este trabajo esbozará dos casos: las investigaciones sobre las ruinas de Palenque en Chiapas (México) y la colección de mapas y manuscritos del Río de la Plata alrededor de 1830.

\section{Diagnosis}

En la reunión del 20 de febrero de 1856 de la Academia Imperial de Ciencias de Viena, Kart von Scherzer (1821-1903) informaba sobre el hallazgo en la biblioteca de Guatemala de un manuscrito del Padre Francisco Ximénez. Este viajero austriaco había aprovechado la estación de lluvias de 1854 para localizar manuscritos en las bibliotecas guatemaltecas. Dado que el clima no permitía realizar viajes o excursiones de carácter científico fuera de la ciudad, Scherzer dedicó esas semanas a rastrear obras que trataran sobre la historia más antigua de los pueblos americanos en los claustros y archivos. Con el mismo cuidado con que recopilaba datos al aire libre propio de su profesión de tipógrafo, organizaba el viaje según las condiciones climáticas. Las lluvias marcaban las semanas del trabajo en los archivos mientras que las temporadas más secas, las excursiones en el campo.

Scherzer, quien en Viena había trabajado en relación con la imprenta y la tipografía, encontró en las bibliotecas desorden, "ausencias", pero también varios manuscritos valiosos (cf. Wehrheim 2004). En su informe, Scherzer haría un diagnóstico del estado de los archivos y de las bibliotecas en América Central, intentando explicar el estado de las cosas a partir de los sucesos históricos ocurridos en las décadas precedentes:

\footnotetext{
"Al mismo tiempo se encuentra en las pocas bibliotecas que ya existen en las cinco republicas una gran falta de manuscritos que tratan esta materia. En ningún lugar de los estados de Costa Rica, Nicaragua, Honduras y San Salvador se halla un solo documento relativo á la historia antigua de este pais. Esta falta completa de escritos no se puede explicar de otra manera, sino por el estrago de las diversas revoluciones que las republicas de Centro-América han experimentado desde su separación de la metrópoli en 1823, en las cuales un gran número de documentos importantes fueron perdidos ó sacados del pais. Se sabe que, cuando en el año 1829, despues de la supresión de todos los conventos por el general Morazan, muchas de estas casas venerables se transformaron en cuarteles y
} 
presidios, montones de libros y manuscritos fueron sacados de sus depósitos para fabricar cartuchos. Otros tesoros antiguos se extraían por la Habana, Madrid, Toledo y Sevilla adonde los monjes expulsados y los partidarios fugitivos de la Corona de Castilla los quisieron poner en seguridad. Tambien por Méjico fueron transportadas algunas escrituras de interes en el corto tiempo del Imperio de Iturbide (1822 -23)" (Scherzer 1857: VIII-IX)

La observación de Scherzer sobre el estado de los repositorios donde, olvidadas, dormían las fuentes de la historia antigua americana, no era la primera. Las reformas políticas del siglo XVIII, las revoluciones, la guerra, la disolución del imperio español, los diversos gobiernos, el permanente cambio en el trazado de fronteras y la constitución de nuevos estados rigen como constante y condición de la práctica de la historia en América Central pero también en el resto del continente americano. Como ha señalado Cañizares-Esguerra (2002), la dispersión de las fuentes con posterioridad a la caída y disolución del Imperio español representa una de las condiciones que determinará la escritura de la historia y la práctica de la anticuaria americanas. En ese marco, la independencia de las nuevas repúblicas en los años 1810-1820 genera una situación que hasta ahora ha sido poco estudiada: la supervivencia y el nuevo orden que adoptarán los archivos burocráticos coloniales durante la revolución, la guerra y la organización nacional. Si se considera que sin burocracia no se puede gobernar, los archivos administrativos americanos de los primeros años del siglo XIX constituyen un objeto muy concreto para estudiar la transformación de la burocracia del régimen colonial en la burocracia de las nuevas naciones. Como es sabido. los legajos coloniales se almacenaban no solamente en Sevilla sino también en las diferentes oficinas del gobierno local, como las Intendencias, Capitanías o Tribunales de Cuentas. El gobierno colonial representó una empresa de enormes dimensiones en lo que respecta a la producción de manuscritos, originales y copias, que alimentaban los diferentes niveles de la burocracia española. Normalmente, según las reglas de la administración, cada informe debía hacerse en triplicado, pero abundan los casos donde los expertos a cargo de dichos informes conservaron una copia para ellos (Aranda Pérez 2005, Carrasco Canals 1975).

En esos años de reforma administrativa y política, abundam los traslado de la documentación de su depósito original a otros repositorios o con destino desconocido. Por otro lado, muchos funcionarios de la corona permanecieron en América. Los médicos del protomedicato, los 
llamados curas ilustrados, los pilotos, los ingenieros geógrafos del real cuerpo de ingenieros militares o, simplemente, los empleados, es decir, aquellas personas que como trabajo producian y guardaban papeles y legajos, se transformaron, según la feliz expresión de Jorge Gelman (1997), en "funcionarios en busca del Estado". En el ínterin, sin Estado, sin Príncipe, muchos de los legajos coloniales -o sus copias- empezaron a ser considerados y conservados como propiedad particular.

Al mismo tiempo, los nuevos gobiernos reclutaban en Europa un nuevo cuerpo técnico, supuestos funcionarios que, al llegar a la ciudad de destino, muchas veces se encontraban con una situación y un gobierno diferentes a los que los habían contratado. Esta situación se repitió indefinidas veces $\mathrm{y}$, así, las obligaciones contraídas hacia personajes como Pietro de Angelis (llegado a Buenos Aires en 1827) serían ignoradas por los nuevos gobiernos. Estos nuevos emigrados y los viejos funcionarios compartirían la larga búsqueda de un Estado que los cobijara como cuerpo letrado de su administración. Sea como aliados o como competencia, ambos grupos trataron de sobrevivir en América gracias a su saber. Los recién llegados rápidamente descubrieron que los antiguos funcionarios o sus herederos conservaban colecciones de objetos, mapas y manuscritos que, en Europa, habían adquirido un alto valor comercial dado el interés que generaban desde el punto de vista científico. Así, en el Río de la plata, los sacerdotes Saturnino Segurola, Bartolomé Doroteo Muñoz y Dámaso Antonio Larrañaga, con el objetivo de estudiar la naturaleza local para propanver al bien común, coleccionaron manuscritos coloniales, objetos de historia natural, instrumentos cientificos y libros, (Podgorny y Lopes 2008, Di Stéfano 2004).

En las décadas de 1820 y 1830 aparece un nuevo actor: los cónsules de los países que reconocen la existencia de las nuevas Repúblicas. Gran Bretaña, Francia, los Estados Unidos de América y el Reino de Cerdeña, Chipre y Jerusalén, Ducado de Saboya y Montferrat, Principado de Piamonte envían o nombran sus representantes con el objetivo de promover sus intereses comerciales y proteger el interés de sus ciudadanos residentes en estas regiones. Los cónsules coleccionaron de manera activa datos, mapas y documentos sobre estos territorios. Como el caso de Woodbine Parish en el Río de la Plata representa, los cónsules rápidamente armaron "cadenas de información”, es decir eslabones de personas ilustradas, en particular médicos de su nacionalidad e idioma, que desde distintos puntos del territorio podían enviar datos, documentos y objetos. A través de estas cadenas circularon los manuscritos encontrados en los archivos locales, así como observaciones y las rutas de navegación de los ríos, los caminos a través de la selva, las pampas o 
los desiertos (Podgorny 2007 b). Articuladas también con las redes del tráfico de mercancías, a través de estas cadenas los cónsules alimentaron sus arcas y los naturalistas viajeros -como Darwin, d'Orbigny o Sellow- pudieron enterarse del paradero de los mapas, los minerales, los fósiles, las ruinas, los animales y las plantas.

Los diversos actores de estos grupos (viajeros, sabios locales, funcionarios de los cuerpos técnicos coloniales, cónsules, comerciantes) intercambiaron datos y cosas entre ellos en forma de transacciones comerciales, regalos de cortesía o presentes diplomáticos. Y así, frecuentemente, las copias y originales de los manuscritos coloniales fueron enviados a Europa para terminar en los repositorios o colecciones privadas de Londres y París. Como escenario aparece disponible un corpus de documentos elaborados por el Real cuerpo de ingenieros militares o los funcionarios españoles (Capel et al. 1988) y mantenidos como información confidencial de la administración colonial. Después de la independencia estos documentos perderían este carácter a raíz de la labilidad de los nuevos gobiernos y la imposibilidad de ejercer su control. Paradójicamente, en ese descontrol, se los considerará "nuevos descubrimientos" y se usarán como evidencia de la oscura voluntad con la que España habría regido sus colonias. Las copias dos mapas y manuscritos -y también sus originales- se transformaron en una mercancía más, que, dependiendo de su originalidad y rareza, alcanzaría un alto valor monetario en Europa. En estas condiciones, los manuscritos se introducen en los círculos eruditos europeos, en las colecciones privadas o en las mesas de los editores. La publicación de estos manuscritos y la circulación de los libros resultantes estimularon la fiebre por buscar, recopilar, vender y publicar otros documentos (Podgorny 2011 b). En las secciones que siguen me referiré al descubrimiento y la circulación de manuscritos sobre las ruinas descubiertas en las cercanías de Palenque, y, segundo, la circulación y publicación en Buenos Aires de documentos realizados en los años del Virreinato del Río de la Plata.

\section{Una ciudad descubierta en Guatemala, en las cercanías de Palenque.}

En 1821, el editor Henry Berthoud de Londres publicaba un libro con el título "Description of the Ruins of an ancient city, discovered near Palenque, in the Kingdom of Guatimala, in Spanish America". Se trataba de la traducción al inglés de un manuscrito escrito en español, encontrado en el archivo de la ciudad de Guatemala por un médico británico 
quien, a su vez, se había encargado de hacerlo llegar hasta Inglaterra. El traductor inglés dedicaba esta obra al conocido e influyente político whig Sir Henry Richard Fox, Lord Holland, quien había vivido en España y promovía la difusión en Inglaterra de la literatura española. Berthout también aclaraba que quien dudara de la existencia del manuscrito original y de los dibujos podía acercarse al domicilio de la editorial. Muy poco después, en 1823, aparecía una traducción alemana de esta versión inglesa como: Huehuetlapallan, Amerikas grosse Urstadt in dem Königreiche Guatemala. El nuevo título se refería al supuesto nombre que la ciudad habría tenido en el pasado (Podgorny 2011a).

Este escrito, de cuya historia y difusión se han ocupado varios auto$r^{2}{ }^{2}$, empezaba con el informe oficial del capitán español Antonio del Río al comandante general de Guatemala. Del Río informaba sobre su inspección en mayo de 1787 de las llamadas "Casas de Piedras", unas ruinas encontradas en las cercanías de Palenque, según el examen ejecutado siguiendo la real orden del 15 de mayo de 1786. Del Río describía la ciudad en base a, en primer lugar, los protocolos de los ingenieros militares para medir y determinar las posibilidades económicas del paisaje y de las instalaciones humanas y, segundo, las instrucciones de Juan Bautista Muñoz, cosmógrafo general de Indias, quien estaba coleccionando los materiales para una historia general de América (cf. Bas Martín 2002, Ballesteros Beretta 1942). En este sentido, el manuscrito de del Río articulaba el saber de los anticuarios y el de los ingenieros, una articulación que generaría una nueva manera de describir las ruinas, tal como aparece también en los resultados de la Real Expedición Anticuaria (1805-1809). Comandada por Guillermo Dupaix, la expedición se dedicó a medir y a transformar en planos a las ruinas de Nueva España (Podgorny 2007 a). Como consecuencia de la muerte de Muñoz en el año 1799 y de los acontecimientos políticos de la segunda década del siglo XIX, estos informes permanecieron inéditos, un motivo más para que los ingleses acentuaran la "apatía española" respecto de las cosas científicas del Nuevo Mundo (cf. Berthoud 1822). Las reseñas alemanas, por el contrario, señalaban la necesidad y el deseo de nuevas investigaciones en el lugar donde del Río habría visto las ruinas (Podgorny 2011a).

La difusión y circulación de este escrito generó nuevas expediciones y también la búsqueda de nuevos manuscritos. Marie-France Fauvet Berthelot, Leonardo López Luján y Susana Guimaraes (2007) estudiaron

2 La bibliografía sobre este tema es incontable. Puede consultarse Alcina Franch 1965, 1995, Castañeda Paganini 1946, García Sáiz 1994, Podgorny 2011 y la bibliografía allí citada. 
las rutas de las tres libretas y de las 140 láminas que resultaron de la Real Expedición Anticuaria desde la muerte de Dupaix en 1817, luego de la independencia de México. En 1824 Latour Allard, un francés de Nueva Orleans, llegaba a México, donde compraría una colección de dibujos coloniales y de objetos antiguos mexicanos que luego llevaría a Francia con la intención de revenderlos. Ya en junio de 1826, la Revue Encyclopédique intentaba despertar el interés del gobierno francés para que adquiriera dicha colección y Humboldt sería invocado para acentuar la importancia del asunto. Se trataba de los dibujos que Luciano Castañeda, el dibujantes de la Real Expedición, conservaba como parte de su propiedad y que habia vendido al primero que estuvo dispuesto a pagarlos, para compesar, así, los honorarios nunca recibidos. En el marco de la disolución del Virreinato de Nueva España, donde nadie se sentía obligado a responder por los contratos de la administración anterior, Castañeda disponía de los resultados de su trabajo y los vendía a la mejor oferta. Pero no solo Castañeda se aprovechaba de este comercio: pocos años después, como ha mostrado Miruna Achim (2010), en 1828 Isidro Icaza, primer director del Museo Nacional de México establecido en 1825, intercambiaba con el francés Henri Baradère las copias de los dibujos de Castañeda, conservadas en el museo, por una colección de pájaros africanos embalsamados.

Según las investigaciones antes citadas, Latour-Allard trató de vender la colección en París y, ante la falta de respuesta, en Londres y Berlín. El precio pedido parecía demasiado alto y ningún gobierno quería invertir esa suma en cosas de dudosa estética. Los dibujos finalmente fueron adquiridos por Agostino Aglio, el dibujante contratado por Edward King, Lord Kingsborough para ilustrar su gran compilación de antigüedades mexicanas para que demostraban los contactos que habrían existido entre las civilizaciones del Nuevo y del Viejo Mundo. Finalmente, años más tarde, los objetos serían comprados por un coleccionista de París y recién en 1849, el gobierno los adquiriría para el museo del Louvre. La publicación de Antiquities of Mexico de Aglio-Kingsbourough (18311848) en Londres y las "Antiquités mexicaines" de Baradère (1834) hicieron que estos dibujos realizados por encargo de la administración colonial se expandieran entre los anticuarios de ambos lados del Atlántico. Así, mientras los objetos quedaban anclados en París en una colección difícil de vender, los dibujos contiuaban su circulación en las bibliotecas y, en esa forma, regresaban a América para seguir alimentando la búsqueda de ruinas, antigüedades, planos, láminas y manuscritos. 


\section{La colección de Angelis: secretarios, sacerdotes, un par de viudas y un cónsul}

Miremos ahora hacia Buenos Aires en 1827: en ese año llegaba de París el napolitano Pietro de Angelis, antiguo preceptor de los hijos de Murat y seguidor de la nueva ciencia de Vico. Muy pronto, luego de su arribo, de Angelis se hallaba sin trabajo a raíz de la disolución del gobierno de Rivadavia, quien lo había contratado. A raíz de ello, de Angelis procuraría sobrevivir en Buenos Aires como periodista, tipógrafo, educador y secretario del Gobernador Juan Manuel de Rosas (cf. Becú 1941, Sabor 1995, Myers 1995). Allí, en Buenos Aires, se encontraría también con el círculo de sacerdotes ilustrados que se dedicaba a la política y a coleccionar objetos de historia natural, manuscritos de los jesuitas, descripciones, vocabularios indígenas y libros (Di Stéfano 2004, Podgorny 2007 b). Estos sacerdotes no solo tenían acceso a los archivos de la Iglesia y a los de las supervivientes instituciones coloniales: atesoraban los conocimientos y las prácticas necesarias para leer, copiar y transcribir dichos manuscritos. De esta confluencia de prácticas y acontecimientos históricos resultó una colección de documentos que, como de Angelis rápidamente entrevió, posibilitaba escribir y publicar una historia de la ocupación española de los territorios ahora argentinos.

No solo ello: de Angelis estableció rápidamente contacto con las familias y viudas de los pilotos y geógrafos de la administración colonial, que seguían viviendo en Buenos Aires y Montevideo. Estas familias guardaban como parte de su herencia o propiedad, copias $u$ originales de los mapas y descripciones del país, realizados como funcionarios coloniales. Alimentaban también la esperanza de poder venderlos a la usanza de Luciano Castañeda (Becú 1941, cf. Badini 1999, Podgorny 2011b).

Como en Nueva España, la ruptura del orden colonial relajó asimismo los controles sobre el secreto y la integridad de los documentos, cuya central antes residía en la administración transatlántica española. Los pilotos, ingenieros y dibujantes sin príncipe o Estado que pudiera adquirir su trabajo, se encontraron en posesión de objetos que empezaban a cobrar cada vez mayor relevancia para el desarrollo del comercio entre América del Sur e Inglaterra. Francia y los demás países comerciales. Es decir, en sus casas se alojaban las claves y las rutas para adentrarse en el interior argentino, los contornos de la costa atlántica y las rutas a través de los ríos hacia el Chaco, Chiquitos, Moxos y Paraguay (García y Podgorny e.p.) 
De Angelis en 1836 empezó publicar como "Colección de Obras y Documentos relativos a la Historia Antigua y Moderna de las Provincias del Río de la Plata", transcripciones de los documentos y manuscritos depositados en los archivos públicos, en los departamentos topográficos, en la colección del padre Saturnino Segurola o propiedad de las familias de los pilotos e ingenieros militares. Estos textos trataban no solamente de los derechos adquiridos por Buenos Aires sobre los territorios sino también sobre el potencial económico de estos territorios. Generaron más de un entuerto y más de una acusación de robo, extravío o maltrato de papeles (cf. Badini 1999). De Angelis, como empresario de la supervivencia en América, armó una colección que se transformaría en el centro de la historia antigua del Río de la Plata.

En particular, el cónsul británico Woodbine Parish se interesó por el trabajo de de Angelis como editor de documentos coloniales. Mientras Parish estuvo en Buenos Aires (1825-1832), visitaba con frecuencia la colección de Segurola, donde encontró, además de un cráneo de Megatherium (Podgorny 2007 b), una valiosa colección de manuscritos, la misma a la que accedía el napolitano. De Angelis permaneció por muchos años en contacto comercial con Parish y con los ingleses ofreciéndor las cosas más diversas, desde un recado y monetarios hasta los huesos de los animales fósiles de las pampas y las corazas de un monstruo antediluviano. Un lugar destacado lo ocupaban los manuscritos, libros e información de las provincias del Plata (Podgorny2011 b). A través del cónsul, de Angelis intercambiaría cartas con el Royal College of Surgeons, Wiliam Clift y Richard Owen y, recibiría en retorno los libros que en Inglaterra se estaban publicando sobre los viajes de Darwin. De esta manera e editor y tipógrafo Pietro de Angelis fue quizás uno de los primeros lectores sudamericanos de las observaciones geológicas y zoológicas de Darwin (Podgorny 2007 b)

Para concluir, ¿qué significado tienen estas situaciones aquí presentadas? Por un lado, tenemos esos lugares de difícil acceso donde se hallan las ruinas y los objetos. Por otro, escritos y dibujos, mapas e información sobre territorios que pueden rastrearse en las rutas de comunicación, el comercio y el transporte y que, en gran parte, desembarcaron fragmentados en Europa. Esta fragmentación de los objetos americanos implica también la citada interacción entre ingenieros militares y anticuarios. Si esta situación se toma en serio, surge el siguiente panorama: Palenque, como objeto arqueológico, puede -y fue- estudiado en espacios completamente diferentes, en los distintos espacios de descubrimiento de los manuscritos y de los objetos: el sitio arqueológico, los museos, las colecciones, las bibliotecas y los 
archivos, allí donde se guardaron las cosas, los documentos, los mapas o los libros sobre las ruinas. El objeto de investigación de esta manera se une a estas rutas del saber, a los actores y caminos que intervienen en su transmisión y a los lugares donde se conserva y archiva. En ese sentido, De Angelis representa un caso paradigmático de la circulación de datos entre América y Europa y también de la transmisión del saber del saber colonial en el siglo XIX, que surgirá como el sedimento de las prácticas de los copistas, los tipógrafos, los ingenieros, los pilotos, los dibujantes y los secretarios.

Con estos dos casos espero haber mostrado la intricada red de rutas, nudos y relevadores del flujo de manuscritos que modelaron el saber sobre Iberoamérica. Estos medios de la transmisión muestran que se tratan de fuentes fundamentales de la historia antigua pero también constituyem los restos de la historia turbulenta de las nuevas naciones americanas.

\section{Agradecimientos}

Una versión de este trabajo fue presentada y discutida en la serie de conferencias "Der Bicentenario in Lateinamerika - Blicke auf 200 Jahre Unabhängigkeit" organizado por la Universidad de Bonn. Agradezco los comentarios y sugerencias de Karoline Noack, Mechthild Albrecht, Monika Wehrheim y Wolfgang Schäffner. Escrito durante mi estadía como investigadora invitada en el Instituto Max Planck de Historia de la Ciencia de Berlín (Departamento 3; Prof. Hans-Jörg Rheinberger), este trabajo forma parte del Proyecto PIP 0116 dirigido por la autora y la Dra. Susana V. García. 


\section{Bibliografía}

Achim, Miruna. 2010. "Setenta pájaros africanos por antigüedades mexicanas : canjes de objetos y formación del Museo Nacional de México (1825-1867)", L'Ordinaire latino-américain, 212, pp. 13-32.

Alcina Franch, José. 1965. 'Los viajes de exploración arqueológica por México de Guillermo Dupaix', Anuario de estudios americanos, 22, pp. 889-917.

1995. Arqueólogos o anticuarios. Historia antigua de la Arqueología en la América española. Barcelona: Serbal.

Aranda Pérez, Francisco José. 2005. Letrados, juristas y burócratas en la España moderna. Ediciones institucionales, 47. Cuenca: Universidad de Castilla-La Mancha.

Badini, Gino. 1999. Lettere dai due mondi. Pietro De Angelis e altri corrispondenti di Carlo Zucchi. Reggio Emilia.

Ballesteros Beretta, Antonio. 1942. “D. Juan Bautista Muñoz: La Historia del Nuevo Mundo". Revista de Indias, 10, pp. 589-660.

Ballesteros Gaibrois, Manuel. 1960. 'Nueva Noticia sobre Palenque en un manuscrito del Siglo XVIII', Cuadernos del Instituto de Historia, Serie Antropológica 11.

Bas Martín, N. 2002. El cosmógrafo e historiador Juan Bautista Muñoz, 1745-1799. Valencia: Universitat de València.

Becú, Teodoro y José Torre Revello, 1941. La Colección de Documentos de Pedro de Angelis y el Diario de Diego de Alvear. Buenos Aires: Jacobo Peuser.

Berthoud, Henry, 1822. "Prólogo" a Antonio del Río, Description of the Ruins of an Ancient City discovered near Palenque, in the Kingdom of Guatemala, in Spanish America. Translated from the original manuscript report of Captain Antonio del Río: followed by Teatro Crítico Americano; or a critical investigation and research into The History of the Americans, by Doctor Paul Felix Cabrera of the city of New Guatemala. London: Henry Berthoud. 
Bourguet, Marie-Noëlle. 2010. "A Portable World: The Notebooks of European Travellers (Eighteenth to Nineteenth Centuries)", Intellectual History Review, 20: 3, pp. 377-400.

Cañizares-Esguerra, Jorge. 2002. How to write the history of the New World: histories, epistemologies, and identities in the eighteenth-century Atlantic world. Stanford: Stanford University Press.

Capel, Horacio, J. Sánchez y O. Moncada. 1988. De Palas a Minerva. La formación científica y la estructura institucional de los ingenieros militares en el siglo XVIII. Barcelona: Serbal/CSIC.

Carrasco Canals, Carlos. 1975. La burocracia en la España del siglo XIX. Madrid: Instituto de Estudios de Administración Local.

Castañeda Paganini, Ricardo. 1946. Las ruinas de Palenque. Su descubrimiento y primeras exploraciones en el Siglo XVIII. Guatemala: Ministerio de Educación Pública.

Crespo, Horacio, 2008. "El erudito coleccionista y los orígenes del americanismo", en: Altamirano, Carlos (director). Historia de los intelectuales en América Latina. 1. La ciudad letrada de la conquista al modernismo (Jorge Myers, editor del volumen), Buenos Aires: Katz. pp. 290-311.

Di Stéfano, Roberto. 2004. El púlpito y la plaza: clero, sociedad y política de la monarquía católica a la república rosista. Buenos Aires: Siglo Veintiuno.

Dupaix, Guillermo. 1834. Antiquités mexicaines. Relation des trois expéditions du Capitaine Dupaix ordonnées en 1805, 1806 et 1807, pour la recherche des antiquités du pays, notamment celles de Mitla et de Palenque; accompagnée des dessins de Castañeda, membre des trois expéditions et dessinateur du musée de Mexico et d'une carte du pays exploré, suivie d'un parallèle de ces monuments avec celles de l'Égypte, de l'Indostan et du reste de l'Ancien Monde par M. Alexandre Lenoir, d'une dissertation sur l'origine de l'ancienne population des deux Amériques et sur les diverses antiquités de ce continent par M. Warden, avec un discours préliminaire par $M$. Charles Farcy et des notes explicatives, et autres documents para MM. Baradere, de St. Priest, et plusieurs voyageurs qui ont parcouru l'Amérique. Paris: Bureau des Antiquités Mexicaines, Jules Didot l'ainé. 
Fauvet-Berthelot, Marie-France, Leonardo López Luján y Susana Guimarães. 2007. "Six personnages en quête d'objets. Histoire de la collection archéologique de la Real Expedicion Anticuaria en NouvelleEspagne", GRADHIVA, 6, pp. 105-126.

García, Susana e I. Podgorny, e.p. "La "Casa de los Pilotos", las escorias de la Patagonia y el naturalista de la barca inglesa", En: Rosaura Ruiz, Miguel Ángel Puig-Samper y Graciela Zamudio (eds.) A 150 años de la publicación de el Origen de las especies, Universidad Nacional Autónoma de México y Consejo Superior de Investigaciones Científicas-España.

García Sáiz, Ma. Concepción. 1994. 'Antonio del Río y Guilermo Dupaix. El reconocimiento de una deuda histórica', Anales del Museo de América, 2, pp. 99-119.

Gelman, Jorge. 1997. Un funcionario en busca del Estado: Pedro Andrés García y la cuestión agraria bonaerense, 1810 -1822. Buenos Aires: Universidad de Quilmes.

Kingsborough, Edward King, Viscount. 1830-48. Antiquities of Mexico: comprising fac-similes of ancient Mexican paintings and hieroglyphics, preserved in the royal libraries of Paris, Berlin and Dresden, in the Imperial library of Vienna, in the Vatican library; in the Borgian museum at Rome; in the library of the Institute at Bologna; and in the Bodleian library at Oxford. Together with the Monuments of New Spain, by M. Dupaix: with their respective scales of measurement and accompanying descriptions. The whole illustrated by many valuable inedited manuscripts, by Augustine Aglio. London.

Myers, Jorge. 1995. Orden y virtud: el discurso republicano en el régimen rosista. Buenos Aires: Universidad de Quilmes.

Podgorny, Irina. 2007 a. "The reliability of the Ruins", Journal of Spanish Cultural Studies, 8 (2), pp. 213 - 233.

2007 b. “De ángeles, gigantes y megaterios. Saber, dinero y honor en el intercambio de fósiles de las Provincias del Plata en la primera mitad del Siglo XIX", en Salvatore Ricardo (ed.), Los lugares del saber. Contextos locales y redes transnacionales en la formación del conocimiento moderno. Rosario: Beatriz Viterbo. 125-57. 
2008. "Antigüedades portátiles: transportes, ruinas y comunicaciones en la arqueología del siglo XIX". História, Ciências, Saúde -Manguinhos. 15 (3), pp. 577-95.

2011 a. "Silent and alone". How the ruins of an ancient city found close to Palenque were taught to talk the language of archaeology, en Ludomir Lozny (ed.). Comparative Archaeologies. A Sociological View of the Science of the Past. Spreinger: Nueva York. Pp - 527 - 553.

Podgorny, I. Mercaderes del Pasado: Teodoro Vilardebó, Pedro de Angelis y el comercio de huesos y documentos en el Río de la Plata, 1830-1850, Circumscribere: International Journal for the History of Science, 9, feb. 2011. Available at: http://revistas.pucsp.br/index.php/circumhc/article/ view/5272. Date accessed: 16 Jun. 2011.

Podgorny, Irina y Maria Margaret Lopes. 2008. El desierto en una vitrina. Museos e historia Natural en la Argentina, 1810-1890, Mexico: Limusa.

Sabor, Josefa. 1995. Pedro de Angelis y los orígenes de la bibliografía argentina: ensayo bio-bibliográfico. Biblioteca "Dimensión argentina". Buenos Aires: Solar.

Scherzer, Karl, 1856. "Über die handschriftlichen Werke des Padre Francisco Ximenez in der Universitäts-Bibliothek zu Guatemala", Kaiserl. Akademie der Wissenschaften in Wien. Sitzungsberichte der Kaiserlichen Akademie der Wissenschaften,Philosophisch-Historische Classe. 19, pp. 166-86.

Scherzer, Karl, y Francisco Ximénez. 1857. Las historias del origen de los Indios de esta provincia de Guatemala, traducidas de la lengua quiché al castellano para mas comodidad de los ministros del S. Evangelio. Londres: Trübner.

Wehrheim, Monika, 2004. "Ein Text im Spiegel seiner Verortungen: Das Popol Vuh", en Sabine Hofmann y Monika Wehrheim (eds.), Lateinamerika. Ort und Ordnungen des Wissens, Festschrift für Birgit Scharlau. Tübingen: Narr, pp. 123-142. 


\section{Abrindo as gavetas: Emília Snethlage (1868-1929) e as coleções ornitológicas do Museu Goeldi e do Museu Nacional do Rio de Janeiro em 1922.}

Miriam Junghans ${ }^{1}$

Em 1922 a ornitóloga alemã Emília Snethlage (1868-1929) transferiu-se, do Museu Goeldi², em Belém do Pará - do qual fora diretora -, para o Museu Nacional do Rio de Janeiro. Em dezembro desse ano o Museu Nacional recebeu uma coleção de mais de mil espécimes zoológicos, principalmente aves, oferecida pelo museu paraense (Brasil, 1922). Aparentemente tratava-se de uma transferência usual entre instituições científicas, mas não há notícia de uma contrapartida, de espécimes equivalente em número ou valor científico, do Museu Nacional para o Museu Goeldi, como era de praxe entre esse tipo de instituições.

Os estudos sociais da ciência têm apontado, a partir dos anos 1990, para as possibilidades oferecidas pela análise de práticas como o trabalho de campo e o colecionismo, que permitem apreender novos aspectos da história das instituições científicas e dos processos envolvidos na institucionalização das ciências. Tal mudança epistemológica teve início com os estudos que se dedicaram à ciência feita em determinadas localidades e instituições, abandonando a premissa aceita inicialmente, da universalidade da ciência, diante da qual práticas localizadas espacialmente adquiriam, forçosamente, um estatuto inferior. Essa nova orientação pode ser exemplificada pela proposição de Steven Shapin, citada por Margaret Lopes, segundo a o qual conhecimento científico é

1 Doutoranda do Programa de Pós-graduação em História das Ciências e da Saúde Casa de Oswaldo Cruz/Fiocruz. E-mail: miriamjungagmail.com

2 Denominada, em 1894, Museu Paraense de História Natural e Etnografia, a instituição teve o nome alterado, em 1900, para Museu Goeldi e, em 1931, para Museu Paraense Emilio Goeldi. 
produzido em "sítios específicos e carrega de modo discernível as marcas desses locais de produção" (citado por Lopes, 2001, p.882). Além de Lopes outros autores, como Dorinda Outram (1997), Lorelai Kury (2001) e Robert Kohler (2002) ofereceram análises ligadas aos lugares de produção do conhecimento científico. Dentre esses lugares se destacam os museus de história natural, que se consolidaram institucionalmente e cresceram significativamente em número em todo mundo e também no Brasil na segunda metade do século XIX.

Nos museus de história natural as coleções de espécimes ocupam um lugar central: interligam as viagens de pesquisa e coleta, os estudos de classificação dos espécimes, dando-lhes materialidade, e a partir delas são organizadas as exposições e os catálogos. Essas coleções são, portanto, o coração dos museus, e através de seu estudo é possível examinar aspectos da trajetória dos cientistas, das redes nas quais esses profissionais estavam inseridos, das práticas de campo e de gabinete, e das próprias histórias institucionais.

Tendo a transferência de espécimes zoológicos do Museu Goeldi para o Museu Nacional, em 1922, como ponto de partida, a proposta é compreender quais - e de que forma - diferenças institucionais estavam envolvidas nesse movimento, e como essas diferenças institucionais podem ser percebidas na produção científica de Emília Snethlage. Para tanto é necessário conhecer algo da trajetória científica da nossa personagem principal.

\section{Emília Snethlage}

A ornitologia sempre teve um estatuto diferenciado entre as coleções de espécimes de história natural. A beleza e ubiqüidade dos seus representantes, aliada a uma certa facilidade de preparação e conservação dos exemplares, quando comparada à das outras classes de vertebrados, acabou levando à organização de coleções extensas, que permitem pesquisas detalhadas a partir das variações dos espécimes. Esse seria um fator essencial para a história natural, principalmente após a entrada em cena das concepções darwinistas. A riqueza da ornis brasileira sempre foi um fator de atração para os especialistas em aves. Entre os estrangeiros que desenvolveram pesquisas em nosso país estava a ornitóloga alemã Emília Snethlage, que chegou a Belém do Pará em 1905 e trabalhou no Brasil até falecer, durante uma viagem de estudos e coleta, em Porto Velho, em 1929. 
No final do século XIX e nos primeiros anos do XX, as universidades alemãs, pressionadas por movimentos pelos direitos femininos, começaram a aceitar, oficialmente, a matrícula de mulheres em seus cursos. Foi o caso de Snethlage, nascida ao norte de Berlim, em 1868, filha de um pastor luterano. Durante dez anos ela havia trabalhado como preceptora na Inglaterra, Irlanda e na própria Alemanha. Em 1899 inscreveu-se, com mais de trinta anos, na Universidade de Berlim, para estudar história natural. Como era comum na Europa então, passou por diversas universidades, como Jena e Freiburg am Breisgau, onde doutorou-se, summa cum laude, em 1904. Passou então a trabalhar no Museu de História Natural de Berlim, como assistente de zoologia, sendo chefiada pelo ornitólogo alemão Anton Reichenow (1847-1941). ${ }^{3}$ Seu contato com Reichenow - que estava integrado às redes que interligavam os profissionais da ornitologia alemã e era editor de dois periódicos científicos da área ${ }^{4}$ - fortaleceria as ligações profissionais estabelecidas por Snethlage a partir da sua passagem pelas universidades e seria importante em vários sentidos. Foi por intermédio de Reichenow que a cientista soube que estava aberto o cargo para um profissional de zoologia em um museu da América do Sul, em Belém do Pará.

\section{O Museu Goeldi}

Em 1866 havia sido fundado em Belém do Pará, por uma entidade particular, mas que contava com o apoio de membros do governo, um museu de história natural. Em 1894 a instituição, que tivera até então uma existência apagada e atribulada, é reativada pelo governador do estado, o positivista Lauro Sodré (1858-1944). Para dirigir o museu com orientação científica é contratado o zoólogo suiço Emilio Goeldi (1859-1917). ${ }^{5}$ O Pará vivia então um período de pujança econômica, seu porto era passagem obrigatória para todo movimento comercial e de transporte da Amazônia, região que vivia o auge do extrativismo da borracha, de grande demanda e preços crescentes no mercado mundial. Essa situação econômica favorável, que começara durante o Império, intensifica-se durante os primeiros anos da República, em virtude da alta da cotação da borracha no mercado

3 Nomes de importância na ornitologia européia do início do século XX iniciaram suas carreiras como assistentes de zoologia no Museu de História Natural de Berlim, como Carl Hellmayr (1878-1944) e Erwin Stresemann (1889-1972; Haffer, 1997).

4 Os periódicos editados por Reichenow eram o Journal für Ornithologie e o Ornithologische Monatsberichte, nos quais Snethlage publicou diversos artigos.

5 Para a biografia de Goeldi ver Sanjad, 2009. 
internacional, da abertura de novas frentes extrativistas e do aumento do orçamento proporcionado pelo crescimento da receita proveniente dos impostos sobre a exportação, antes drenados pelo governo central, e que a reforma tributária de 1891 redirecionara para os estados (Sanjad, 2005). A cidade passou por profundas reformas urbanas e atraiu grandes levas de imigrantes estrangeiros, além de brasileiros provenientes do nordeste e do interior do Pará e, por volta de 1900, contava com aproximadamente 100.000 habitantes. A ciência era parte importante dos ideais republicanos e o novo regime de governo estava empenhado em tornar evidentes as diferenças entre o seu projeto e os feitos do Império, passando a investir na reorganização do museu de história natural.

Emílio Goeldi havia se formado em Jena em 1884 e logo depois viera para o Brasil, atendendo a convite de Ladislau Neto (1838-1894), diretor do Museu Nacional do Rio de Janeiro, instituição na qual trabalhou durante cinco anos. Ao transferir-se para Belém do Pará, em 1894, deu início a profunda reestruturação que consolidou o Museu Paraense e o inseriu nas redes de produção científica nacionais e internacionais, além de ter formulado pela primeira vez no país, segundo Nelson Sanjad, um "projeto científico claro e coerente para a Amazônia" (2006, p.455). Dividido em quatro seções, zoologia, botânica, geologia e etnografia, o museu teria como objetivos "o estudo, o desenvolvimento e a vulgarização da História Natural e Etnologia do Estado do Pará e da Amazônia em particular e do Brasil, da América do Sul e do continente americano em geral" (Regulamento, 1894, p.22). A instituição idealizada e posta em funcionamento por Goeldi era orientada por um projeto que visava a sistematização do conhecimento científico sobre a Amazônia, com ênfase na zoologia e na botânica. O museu funcionaria, portanto, como um centro especializado de produção de conhecimento científico. Para atingir seus objetivos Goeldi, recorrendo ao seu círculo de relações acadêmicas nos museus e universidades da Europa Central, contratou cientistas estrangeiros para trabalharem em Belém e passou a editar, a partir de 1894, o Boletim do Museu Paraense de História Natural e Etnografia, que circulava entre museus e outras instituições científicas nacionais e estrangeiras.

Emília Snethlage havia sido contratada para trabalhar no museu como assistente de zoologia, seção que sempre recebera uma atenção especial por parte de Goeldi, tanto em termos institucionais quanto administrativos. Dentro da zoologia, era a ornitologia que recebia as maiores atenções do diretor do Museu, pois se tratava de área da sua predileção. Chegando a Belém do Pará em agosto de 1905, aos 37 anos, Snethlage começou imediatamente seus estudos sobre a avifauna da região 
amazônica, dando início a uma carreira profícua, durante a qual deixou uma contribuição expressiva para a ornitologia. A obra que a tornou mais conhecida entre os especialistas, o Catálogo das aves amazônicas, de 1914, reuniu o material disponível sobre as coleções ornitológicas do Museu Paraense e de outros museus, e os trabalhos taxonômicos, biológicos e biogeográficos feitos até 1912 pela própria pesquisadora. Nesta obra, considerada por especialistas de fundamental importância para a ornitologia brasileira, são relacionadas 1.117 espécies de aves amazônicas. Suas descrições e análises técnicas serviram de base para os estudos ornitológicos dos setenta anos seguintes (Cunha, 1989, p.91). Quando Emílio Goeldi retornou a sua Suiça natal em 1907, deixou como diretor do Museu o botânico Jacques Huber, e Snethlage passou a diretora da seção de zoologia. O inesperado falecimento de Huber, em 1914, fez com Snethlage passasse a diretora interina da instituição, tornando-se uma das primeiras mulheres, na América Latina, a exercer a direção de uma instituição científica (Cunha, 1989). Alguns meses depois de Snethlage ter assumido a direção do museu, teve início a Primeira Guerra Mundial e, com ela, acirraram-se as dificuldades pelas quais já vinha passando a instituição. À crise financeira do estado do Pará, ocasionada principalmente pelo fim do fluxo financeiro proveniente da extração da borracha, somou-se à crise política, com o alinhamento do Brasil com a política externa norte-americana que acabou levando, em outubro de 1917, ao estado de guerra com a Alemanha. Ter uma alemã como diretora de uma instituição nacional tornou-se insustentável e, em 1917 o governador do estado, Lauro Sodré, demite-a deste cargo permitindo, porém, que se mantenha na chefia da seção de zoologia. Em março de 1918, com o acirramento das hostilidades, o governo do estado intervém novamente na administração do museu, afastando Snethlage completamente da instituição (Cunha, 1989). Com o fim da guerra é reempossada na chefia da seção de zoologia em junho de 1919, e na direção do museu no mês seguinte, permanecendo no cargo até 1921. Quando Snethlage voltou à direção do museu em 1919, a situação social e econômica da Amazônia se alterara profundamente. Com o final do ciclo extrativista da borracha o Pará entrou em um período de depressão econômica que se estendeu até 1930 e que atingiu duramente a instituição. As questões econômicas passaram a ser prioritárias para o governo paraense e 0 apoio ao museu, tanto político quanto financeiro, diminuiu consideravelmente. $\bigcirc$ gradativo afastamento dos funcionários estrangeiros, sem que fossem substituídos, por falta de recursos, acabou minando um dos alicerces sobre os quais se sustentava o museu, a produção científica. O maior patrimônio científico com que o Museu Goeldi ainda podia contar estava nas coleções de espécimes botânicos e zoológicos da Amazônia. 
Em 1921 aparecem artigos anônimos em jornais paraenses, denunciando irregularidades na administração da instituição. Um artigo publicado no Estado do Pará, em 19 de abril, acusa a diretora de permitir o desvio de alimentos destinados aos animais e reparti-los entre os funcionários mais necessitados. Outra denúncia dizia que as residências dos funcionários solteiros eram visitadas por "mulheres de vida duvidosa, sem o menor respeito à direção e às famílias também lá residentes" (Cunha, 1989, p.93-94). Emília Snethlage está isolada. A crise institucional afastara do Museu os demais cientistas estrangeiros. Ela, como mulher sozinha, cientista, estrangeira não é mais aceita pela sociedade local. Exonerada das suas funções pelo governador Emíliano de Souza Castro, ela permanece na chefia da seção de zoologia. Em 1922 transfere-se, como naturalista viajante, para o Museu Nacional do Rio de Janeiro, a convite do paraense Bruno Lobo (1884-1945), então diretor desta instituição (Cunha, 1989).

\section{O Museu Nacional do Rio de Janeiro}

O Museu Nacional do Rio de Janeiro foi fundado como Museu Real do Rio de Janeiro em 1818. Antes dele um entreposto comercial, a 'Casa dos Pássaros', arrecadava, preparava e remetia espécimes de história natural para Lisboa desde o século XVIII. De acordo com Lopes, desde sua fundação a instituição teve um caráter de museu metropolitano, enciclopédico e universal, que se mantém até os dias de hoje (1997, p.324). A instituição centralizava o recebimento das coleções de espécimes enviadas pelos naturalistas brasileiros e estrangeiros que percorriam o território do Brasil. No entendimento da mesma autora, em meados do século XIX - quando ocorre o fortalecimento político do Império brasileiro, através da consolidação da economia agrária e escravocrata -, as ciências naturais não conseguiram se implantar como um projeto unificado. Embora fosse favorecida por benesses imperiais, a emergente comunidade de naturalistas estava dividida entre diversos interesses e diferentes ênfases científicas (Lopes, 1997, p.325). Nos anos 1870 iniciaram-se no Museu Nacional os estudos de novas áreas do conhecimento, que estavam em fase de constituição, como etnologia, antropologia (antropologia física) e paleontologia. Nessa época, o Museu consolidou-se como órgão consultivo do Estado, especialmente para questões de mineração e de agricultura, além de ter suas atividades científicas, concentradas na química e na geologia, fortalecidas (Lopes, 1997, p.325). 
No processo de institucionalização das ciências naturais em curso no final do século XIX, naturalistas como Hermann von Ihering (18501930) e Goeldi foram funcionários do Museu Nacional, ao contrário do que acontecia com seus antecedentes, que estavam principalmente a serviço de instituições de seus países de origem. Esses cientistas estrangeiros, formados em universidades européias e especializados em determinados ramos da história natural, como a zoologia, logo entraram em atrito com o direcionamento mais generalista que regia o Museu do Rio de Janeiro. Goeldi e Ihering, por exemplo, se afastaram da instituição no final da década de 1890 por discordarem, entre outras coisas, da pouca ênfase dada à zoologia, em detrimento da antropologia.

Nesse momento, o Museu Nacional já possuía coleções extensas, amealhadas durante os muitos anos nos quais servira de locus centralizador das coleções de história natural no Brasil. No entanto, a diversidade de interesses sempre cambiantes que o Museu Nacional abrigava, sua orientação universal e voltada para a educação do público, acabou dando origem a coleções que não apresentavam a mesma especialização encontrada no museu de Belém.

O zoólogo Alípio de Miranda Ribeiro (1874-1939), em artigo publicado em 1928, no Boletim do Museu Nacional, traça um panorama das diversas coleções ornitológicas existentes na instituição em 1897. Segundo ele, as coleções dividiam-se em uma coleção para exposição e visitação pública, que compreendia espécies do mundo inteiro e uma coleção seriada, para o estudo dos especialistas. Essa última dividia-se em várias subcoleções provenientes de empreendimentos como a Expedição Científica do Ceará (1862), e de coletores individuais. Miranda Ribeiro ressaltava que o material havia sido trabalhado e retrabalhado várias vezes, de acordo com a parca bibliografia de que dispunham os funcionários do Museu, algumas vezes com a ajuda de especialistas estrangeiros, como o ornitólogo alemão conde Hans von Berlepsch (1850-1915). Segundo ele, o objetivo do artigo que apresentava era demonstrar "o esforço que necessitávamos dispender para realizar alguma coisa de proveitoso no estudo do material (...), para constituir um núcleo de coleções capazes de nos libertar de qualquer tutela e nos tornarmos cientificamente independentes". E continua: "em geral, e de um modo lamentável, as peles antigas não tinham procedência; 'Brasil' era tudo quanto se afirmava antigamente nos estudos realizados" (Miranda Ribeiro, 1928, p.20). Em termos numéricos, segundo os dados fornecidos pela seção de zoologia à Repartição de Estatística do Governo e citados por Margaret Lopes, a coleção ornitológica do Museu Nacional compunha-se, em 1915, de 4.862 exemplares. O caráter universal do museu também podia 
ser detectado também nessas coleções: "ao lado das aves brasileiras, estavam as de outros países da América do Sul, Europa, Ásia, África e Austrália. Não faltavam (...) os esquisitos pingüins da Patagônia, o avestruz africano, o ápterix da Nova Zelândia ou as aves-do-paraíso da Nova Guiné" (Lopes, 1997, p.232).

Um reforço considerável aportou nas coleções do Museu Nacional depois dos trabalhos da Comissão Rondon (1907-1915), da qual participaram cientistas como Miranda Ribeiro. No entanto, as coleções ornitológicas da Comissão foram pouco trabalhadas pelos pesquisadores. Miranda Ribeiro publicou um único trabalho, em 1919, juntamente com Euclides da Costa Soares, relacionando 28 espécies de papagaios coletadas e -enfatizando a relevância desse material para a instituição, já que a maioria dos exemplares que o Museu possuía em seu acervo não tinha procedência- (Sá, Sá e Lima, 2008, p.798).

Em 1922, quando Emília Snethlage chegou ao Rio de Janeiro a situação já deveria estar um pouco melhor, em virtude dos esforços de cientistas como Miranda Ribeiro, mas ainda assim as coleções de aves do Museu Nacional eram, diante da grande especialização das coleções do museu paraense, bastante incompletas, além de não estarem identificadas corretamente.

\section{Abrindo as gavetas}

O Museu Nacional do Rio de Janeiro e o Museu Goeldi, como vimos, guardavam diferenças marcantes, diretamente relacionadas às suas histórias institucionais. A principal delas, no que diz respeito ao trabalho de Snethlage, era a inexistência de um projeto específico e articulado entre todos os setores do Museu Nacional, para a produção de conhecimento científico. Um segundo aspecto, não menos importante, era a ausência de coleções ornitológicas extensas e totalmente organizadas dentro de critérios científicos, como eram as de Belém. A ornitologia do Museu Goeldi podia contar com uma excelente coleção de peles de pássaro, em grande número (para escrever o catálogo, publicado em 1914, ela manuseara mais de 10.000 peles), na qual a avifauna da região amazônica estava muito bem representada e, além disso, contava com literatura que tinha sido mantida, na medida do possível, atualizada, enquanto que a literatura técnica existente no Museu Nacional era deficiente, se comparada com a do museu nortista. Em diversas obras, publicadas durante sua permanência no Rio de Janeiro, Snethlage irá se queixar da falta de material disponível para a comparação de espécimes 
e da ausência de literatura adequada, o que, segundo ela, dificultaria sobremaneira seu trabalho. Diante do que encontrou nas coleções ornitológicas do Museu Nacional do Rio de Janeiro Emília Snethlage viu a necessidade de solicitar a transferência das peles da instituição do norte, para poder dar continuidade ao trabalho científico que vinha desenvolvendo, agora dentro de outros parâmetros institucionais e em outro âmbito geográfico. As condições institucionais do Museu Goeldi e as condições econômicas do Pará devem ter pesado nessa decisão.

Em ofício datado de 31 de dezembro de 1922 o médico paraense Bruno Lobo, diretor do Museu Nacional entre 1915 e 1923, dirige-se ao diretor da Seção de Zoologia da instituição, o professor Hermillo Bourguy Macedo de Mendonça. "Tenho a satisfação", diz o diretor, "de remeter-vos nesta data a belíssima coleção de peles de aves e mamíferos oferecida a este Instituto pelo Museu Goeldi de Belém e trazida pela Dra. Emília Snethlage". Acompanha o ofício uma relação de vinte páginas, contendo as espécies e o número de exemplares de 1.146 peles, das quais 106 de mamíferos (macacos, tamanduás, felinos e roedores, entre outros) e 1.040 de aves 6 .

Com relação à produção científica de Emília Snethlage, as peles de aves que trouxe consigo de Belém do Pará parecem ter representado o acervo mínimo necessário para dar continuidade às suas pesquisas dentro dos padrões nos quais estava acostumada a trabalhar. Pois as peles que trouxe estavam preparadas, classificadas e identificadas dentro de padrões científicos e formavam uma amostra numericamente significativa. Em relação ao número de exemplares então existentes no Museu Nacional, mesmo se levados em consideração os acréscimos originados das explorações da Comissão Rondon, as mais de mil peles trazidas de Belém, identificadas e classificadas, formavam um contingente expressivo e valioso.

A outra face da moeda é que, a partir da década de 1920 o Museu Goeldi viveu um período de ostracismo, abandonado pelo Poder Público e duramente atingido pela depressão econômica. Essa situação se alterou apenas nos anos 1950, quando foi considerado um centro de conhecimento científico sobre a Amazônia, absorvido pela União e vinculado, em 1955, ao então Conselho Nacional de Pesquisas - CNPq. Durante esses trinta anos, as peles trazidas por Emília Snethlage, que poderiam ter se deteriorado no Pará, estiveram nas mãos dos cientistas que faziam suas pesquisas na capital brasileira.

6 As espécies de aves trazidas do Pará poderiam ser comparadas com as já existentes no Museu Nacional, porém esse estudo ultrapassa o escopo do presente artigo. 


\section{Considerações Finais}

A transferência de Emília Snethlage de Belém para o Rio de Janeiro em 1922 confrontou duas realidades institucionais distintas: a grande especialização do Museu Goeldi, expressa através da amplitude e representatividade das suas coleções da avifauna amazônica e o caráter 'metropolitano' e diversificado, enciclopédico, fortemente voltado para a educação, do Museu Nacional, características que também podiam ser detectadas nas coleções ornitológicas da instituição. $O$ universalismo dos museus fundados no início do século XIX se contrapõe à especialização dos museus locais, característica dos museus fundados (ou reativados, como foi o caso do Museu Goeldi) a partir dos anos 1890, como ressalta Lopes (1997, p.324-325). Além disso, é notável o papel desempenhado pela personalidade dos diretores dos museus que, pela sua formação e interesses acabavam conformando as instituições nas quais atuavam (Lopes, 1997, p.326), o que incluía a especificidade que adquiriam as coleções. Para o Museu Nacional serve de exemplo a atuação de Ladislau Neto, com seu grande interesse pela antropologia física, que acabou se tornando uma das mais importantes áreas de atividade da instituição, enquanto que no Museu Goeldi a predileção de Goeldi pela ornitologia foi um dos fatores que influenciou na formação de uma coleção de aves extensa e representativa.

Na produção científica de Emília Snethlage como naturalista viajante do Museu Nacional é possível reconhecer certa continuidade com os trabalhos realizados no Pará, mas também mudanças importantes. A área geográfica estudada ampliou-se, ela passou a percorrer todo o território nacional em busca de exemplares e planejava uma obra de síntese da avifauna brasileira, nos moldes do catálogo publicado pelo Museu Goeldi em 1914, que não teve tempo de publicar. Como em Belém, continuou a se interessar por questões de biogeografia, mas ampliou o alcance das suas considerações, buscando compreender a distribuição das aves em todo o território nacional. ${ }^{7}$ Continuou a publicar em periódicos científicos estrangeiros e no periódico da instituição em que trabalhava, agora o Boletim do Museu Nacional. Certamente os espécimes que levou consigo para o Museu Nacional tiveram um papel importante nas pesquisas que desenvolveu a partir de 1922. E, apesar das diferenças, foi a instituição que a acolheu que possibilitou a continuidade do seu trabalho.

7 Sobre esse assunto ver Lutz, 1957. 


\section{Bibliografia}

BRASIL. Museu Nacional do Rio de Janeiro. Seção de Memória e Arquivo do Museu Nacional/UFRJ. Fundo Museu Nacional. Zoologia. Caixa 6. Ofícios recebidos (1922-1925). Ofício de Bruno Lobo para Bourguy de Mendonça. 31 de dezembro de 1922.

CUNHA, Oswaldo Rodrigues da. Maria Elizabeth Emilia Snethlage. In: Talento e atitude: estudos biográficos do Museu Goeldi, I. Belém: Museu Paraense Emílio Goeldi, p. 83-102. 1989.

HAFFER, Jürgen (com contribuições de Ernst Mayr). Ornithologen-Briefe des 20. Jahrhunderts. Ökologie der Vögel, Ludwigsburg, v. 19. 1997.

JUNGHANS, Miriam. Avis rara: a trajetória da naturalista alemã Emilia Snethlage (1868-1929) no Brasil. Dissertação (Mestrado em História das Ciências) - Programa de Pós-graduação em História das Ciências e da Saúde, Casa de Oswaldo Cruz, Fundação Oswaldo Cruz, Rio de Janeiro. 2009

KOHLER, Robert E. Place and practice in field biology. History of Science, v.40, n.129, p.189-210. 2002.

KURY, Lorelai B. Viajantes naturalistas no Brasil oitocentista: experiência, relato e imagem. In: História, Ciências, Saúde - Manguinhos, Rio de Janeiro, v.8, supl., p.863-880. 2001.

LOPES, Maria Margaret. Viajando pelo campo e pelas coleções: aspectos de uma controvérsia paleontológica. História, Ciências, Saúde - Manguinhos, Rio de Janeiro, v.8, supl., p.881-897. 2001.

LOPES, Maria Margaret. O Brasil descobre a pesquisa científica: os museus e as ciências naturais no século XIX. São Paulo: Hucitec. 1997.

Lutz, Bertha. Emilie Snethlage (1868-1929). In: Relatório anual do Museu Nacional, pelo diretor José C.M. Carvalho. Rio de Janeiro: Museu Nacional, p.39-43. 1957.

MIRANDA RIBEIRO, Alípio de. Notas ornithologicas (VI-a). Boletim do Museu Nacional, Rio de Janeiro, v.IV, n.3. 1928. 
OUTRAM, Dorinda. New spaces in natural history. In: Jardine, N.; Secord, J.A. e Spary, E.C. (Ed.). Cultures of natural history. Cambridge: Cambridge University Press, p.249-265. 1997.

REGULAMENTO do Museu Paraense. Boletim do Museu Paraense de História Natural e Etnografia. Belém, v.1, n.1, p.22-27. 1894.

SA, Dominichi Miranda de; SA, Magali Romero e LIMA, Nísia Trindade. Telégrafos e inventário do território no Brasil: as atividades científicas da Comissão Rondon (1907-1915). História, Ciências, Saúde - Manguinhos, Rio de Janeiro, v.15, n.3, p.779-810. 2008.

SANJAD, Nelson. Emílio Goeldi (1859-1917): a ventura de um naturalista entre a Europa e o Brasil. Rio de Janeiro: EMC. 2009.

SANJAD, Nelson. Emílio Goeldi (1859-1917) e a institucionalização das ciências naturais na Amazônia. Revista Brasileira de Inovação, v.5, n.2, p.455- 477, jul.-dez. 2006.

SANJAD, Nelson. A coruja de Minerva: o Museu Paraense entre o Império e a República, 1866-1907. Tese (Doutorado em História da Ciência) - Rio de Janeiro, Casa de Oswaldo Cruz, Fiocruz. [Publicada como A coruja de Minerva: o Museu Paraense entre o Império e a República (1866-1907). Brasília: Instituto Brasileiro de Museus; Belém: Museu Paraense Emílio Goeldi; Rio de Janeiro: Fundação Oswaldo Cruz. 2010.] 2005. 


\section{6.}

\section{Museos provinciales y redes de intercambio en la Argentina}

Susana V. García ${ }^{1}$

\section{Museos provinciales y redes de intercambio en la Argentina}

En 1929, el norteamericano Laurence V. Coleman tras una gira de ocho meses por Sudamérica patrocinada por la American Association of Museums, publicó un inventario y una breve descripción de los principales museos de los países visitados. El viaje de Coleman se inscribía en una larga tradición de viajes para estudiar museos y otras instituciones científicas (Podgorny, 2009), pero también apuntaba, publicar una lista de museos para posibles intercambios. En ella, la Argentina figuraba con 29 museos estatales - nacionales, provinciales, municipales o universitarios- y uno privado sostenido por la Sociedad Rural Argentina (Coleman, 1929). Si bien la lista no era completa, daba cuenta de las instituciones más activas, conocidas por sus publicaciones, trabajos o la importancia de sus colecciones. En la Capital Federal se concentraban la mitad de ellos; el resto se ubicaba en nueve de las capitales provinciales y en las ciudades de Luján y Rosario. Los museos provinciales comprendían instituciones dedicadas a las bellas artes o, en menor medida, a la historia. Otros acervos -lejos de especializarse- incluyeron objetos de ciencias naturales, piezas arqueológicas, etnográficas, históricas y productos industriales, enfatizando en el carácter "regional" de sus colecciones. Varios de ellos estaban al servicio de las escuelas y dependieron inicialmente de los consejos escolares provinciales. Los museos denominados "regionales" e histórico-coloniales se expandirían a partir

1 CONICET - Museo de La Plata, Facultad de Ciencias Naturales y Museo-UNLP (Argentina). E-mail:garcia_su@yahoo.com.ar 
de la década de 1930 en distintas poblaciones del país. En este trabajo se busca examinar algunos aspectos generales de la historia de esos museos, su participación en los circuitos de difusión y de intercambio científico y las prácticas de coleccionismo local en relación con las propuestas educativas, culturales y científicas de la época.

\section{La expansión de museos y la promoción de lo "regional"}

Al iniciarse el siglo XX el panorama sobre los museos provinciales no era muy alentador. En su calidad de naturalista viajero del Ministerio de Agricultura de la Nación, Eduardo Holmberg (hijo) había tenido la oportunidad de visitar los museos de Paraná, Corrientes y Córdoba, donde el panorama de abandono se repetía en las tres instituciones surgidas a fines del siglo XIX de las alianzas circunstanciales entre los coleccionistas y los gobernadores de turno (Podgorny y Lopes, 2008). En estos casos, la constitución de museos estuvo ligada al pasaje de una colección privada al dominio del estado provincial y el nombramiento del coleccionista como director del mismo. Como señala Podgorny, el optimismo de supervivencia de los estudiosos de la historia natural en la Argentina, los había llevado a pensar en la pronta posibilidad de la existencia de un museo por cada capital provincial, aunque rápidamente ese optimismo se desvanecía al igual que los apoyos y recursos al cambiar los funcionarios de turno. En 1902, Holmberg cuestionaba la existencia de estos museos y proponía trasformarlos en otros específicamente regionales, para su aplicación a las actividades productivas locales (Holmberg, 1902). Este diagnóstico retomaba un tópico insinuado años atrás por algunos naturalistas, docentes y funcionarios escolares, quienes ya habían pregonado la necesidad de reemplazar el estudio de una supuesta naturaleza transnacional por el examen de los especímenes del país y del entorno de sus habitantes. Iniciativas tales como los llamados "museos escolares" se dirigieron inicialmente hacia la promoción del estudio de la naturaleza local y los recursos productivos con los que contaba el país, promoviendo, al mismo tiempo, las prácticas de coleccionismo entre alumnos y docentes (García, 2007; 2010). Más allá de la declaración de principios, la formación de museos en las escuelas tropezaría con problemas vinculados a la catalogación, conservación y uso de los objetos recolectados. Una de estas soluciones fue la creación de una red de museos escolares y un museo central, desde donde se enviarían instrucciones para organizar las colecciones, 
dirigir la recolección de especímenes en cada región y su posterior clasificación y redistribución entre las escuelas. En la transición del siglo XIX al XX, las iniciativas al respecto fueron de corta vida, pero esa idea seguiría apareciendo como una propuesta novedosa durante las siguientes décadas.

Para 1910, los materiales del Museo provincial de Entre Ríos se había incorporado a la Escuela Normal de Paraná y los del de Corrientes a una escuela primaria. Al año siguiente se decretaba el traspaso a una escuela de los objetos de historia natural del Museo Politécnico de Córdoba, donde se mantendrían, en cambio, los materiales históricos y de bellas artes (Agüero, 2009). En los siguientes años se propondrían varios proyectos para la reorganización de esa institución, dando lugar en 1919 a la creación de tres museos: de Bellas Artes, Histórico-Colonial y de Ciencias Naturales. Este último tardó varios años en organizarse y sufrió sucesivas reestructuraciones. Este proceso de división de los acervos de los museos provinciales para dar origen a instituciones más especializadas se repetirá posteriormente en otros museos surgidos a partir de la década de 1910. En estos años, nuevamente se observa un impulso por la creación de museos en las capitales provinciales y un énfasis en el carácter regional que debían tener los mismos.

En 1911 la Dirección General de Escuelas de la Provincia de Mendoza resolvió crear el Museo General Regional, denominado en 1914 "Museo Educacional", momento en que se instala en un edificio construido en 1910 para un jardín de infantes, donde permaneció cerca de cuatro décadas. Su primer director hasta 1923 fue el profesor y naturalista chileno Carlos Samuel Reed, quien desde su llegada a la provincia en 1908 promovió la creación de un museo y las prácticas de formar colecciones de historia natural. Aunque inicialmente fue una institución dedicada al servicio escolar, también se realizaron expediciones arqueológicas y se reunieron colecciones de la fauna y flora de la provincia a partir del trabajo de su director y colaboradores. Reed confeccionó folletos y dio conferencias sobre preparación de insectos y cómo formar museos escolares. Asimismo, dio a conocer las colecciones faunísticas y antropológicas del Museo a través de catálogos y artículos en diarios mendocinos y en el Boletín de Educación provincial. La sección botánica estuvo a cargo del profesor Renato Sanzin, quien herborizó en los alrededores de la ciudad y en la cordillera y remitió al Instituto Darwinion de Buenos Aires parte de las colecciones reunidas para su determinación (Hicken 1923). El envío de ejemplares para su clasificación a los centros científicos de Buenos Aires y La 
Plata fue una práctica común entre coleccionistas y aficionados de varios museos del interior y promovida desde los centros académicos metropolitanos.

En otras provincias, las autoridades educativas apoyaron la creación de museos, especialmente pensados como auxiliares del sistema educativo. En 1914, la Inspección General de Escuelas de Santa Fe creó el Museo Escolar de Ciencias Naturales "Florentino Ameghino" con el objeto de ofrecer materiales didácticos y un espacio para el dictado de las clases de ciencias. A fines de 1919, el Consejo Superior de Educación de Corrientes comisionaba al profesor Valentin Aguilar para que visitara los museos de Buenos Aires y La Plata para procurar colecciones y un método de organización para la institución que se proyectaba (Aguilar, 1928). Al año siguiente se fundó el Museo Regional de la Provincia, dirigido por ese profesor y sobre, base de las colecciones y muebles del antiguo museo provincial, sobrevivientes en una escuela aunque sin catálogos ni identificaciones. Este proceso de conformar un nuevo gesto fundacional apelando al reciclaje de los vestigios de viejas creaciones se repetiría en otros museos. En el caso de la capital entrerriana, una asociación de estudiantes del Colegio Nacional y la Escuela Normal creó un Museo Popular en 1917. En 1924, uno de sus socios fundadores, Antonio Serrano, para entonces docente, aficionado a la arqueología y vocal del Consejo de Educación provincial, propuso a esta entidad crear el Museo Escolar Central y la donación de los materiales del emprendimiento museístico juvenil (Badano, 1947). Al igual que en otros casos, el gestor de la donación asumiría la dirección de la nueva institución. Para los naturalistas y arqueólogos de las provincias, el sistema escolar fue un punto de apoyo para la conformación de lugares de trabajo, posibilidades empleo o un público interesado en sus actividades y obsesiones. Como en Mendoza, los museos de Corrientes y Paraná (Imagen I), se instalaban en los subsuelos de los grandes edificios escolares construidos en la época del Centenario. Además, las vinculaciones con el sistema educativo les permitieron ampliar las redes de colaboradores y recolectores de materiales en zonas alejadas. 


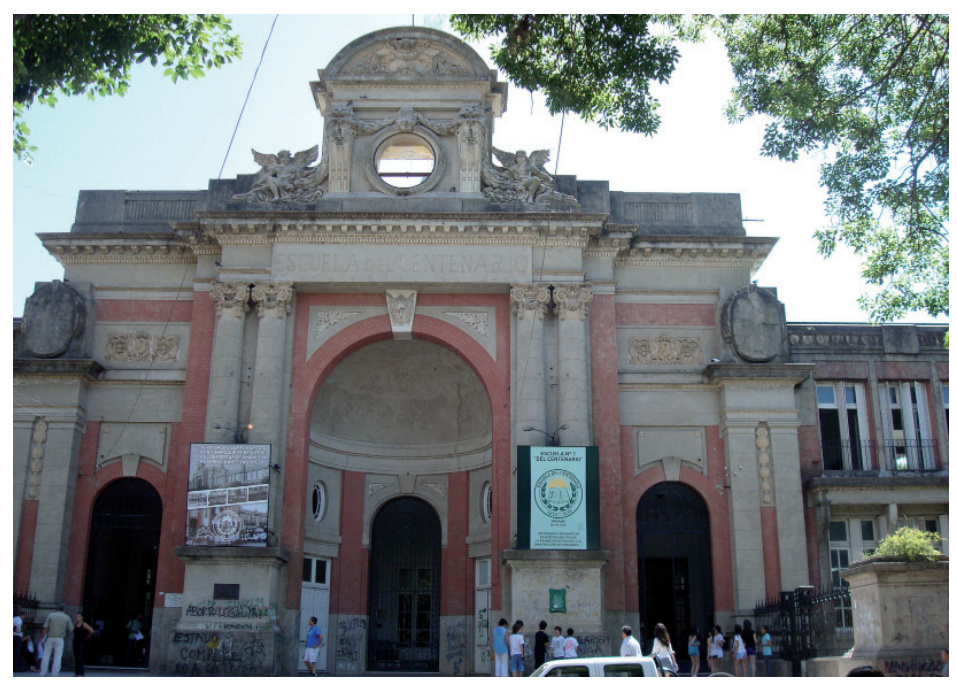

Imagen I: Escuela del Centenario, donde funcionó el Museo de Paraná entre 1924 y 1999, ocupando varios salones del subsuelo.

En 1916, en el marco de los festejos del centenario de la Independencia realizados en el norte del país, se inauguraran otros museos, como el Museo de Historia Natural de Tucumán, cuya creación había sido decretada años antes sin efectivizarse. Poco después este museo fue incorporado a la Universidad de Tucumán, prestando servicios a la enseñanza universitaria y funcionando como un centro regional de investigaciones científicas, pero también abierto al público. Paralelamente en Salta, la sociedad provincial de fomento "Unión Salteña" logró que el gobierno local decretase en junio de 1915 la creación de un museo dedicado a exponer los productos y riquezas del suelo de la provincia, un proyecto que venía fomentando uno de sus miembros: el naturalista danés Cristian Nelson, quien asumiría su dirección por más de treinta años (Piccirilli et al., 1953). También en Santiago del Estero, en 1916 se creaba el Museo Arcaico Provincial, a partir de la donación a la provincia de la colección particular del intendente Alejandro Gancedo (h), un miembro de la elite local, aficionado a la arqueología y conectado a los especialistas de Buenos Aires y La Plata. El gesto político de creación de un museo, amparado en el prestigio que nuevamente cobraban estas instituciones como un elemento de las ciudades modernas, en este caso no sería suficiente para darle vida a una institución o evitar los avatares por los atravesaría. 
La emergencia de estos museos en la década de 1910, sería celebrado desde las páginas de la revista de la Sociedad Argentina de Ciencias Naturales, creada en 1911. Durante la primera guerra mundial se acentuaría la importancia de los temas locales de las ciencias, periodo en el cual los congresos internacionales suspenderían sus reuniones, aunque se generarían encuentros de corte americano y nacional. En 1916, esta asociación organizó su primera reunión nacional en Tucumán, donde se haría énfasis en los contenidos argentinos de la enseñanza, la creación de parques nacionales y se aplaudiría la formación de colecciones y museos regionales (García y Podgorny, 2000). Entre ellos, el director del Museo Nacional de Historia Natural de Buenos Aires, Angel Gallardo, alentaba la creación de estos centros provinciales y la expansión de núcleos de estudiosos de la naturaleza por el interior del país, como el comienzo de un nuevo período de "autonomía científica", que habría de caracterizarse por la "división del trabajo y cooperación colectiva" (Gallardo, 1918-9: 10). Para el director del Museo de Buenos Aires, los museos regionales no debían competir sino armonizar con las actividades de los grandes museos de investigación, reuniendo observaciones in situ y constituyendo un espacio de articulación entre los objetos reunidos y las características propias de la zona: "lo que se ve fuera del museo explica y complementa aquello que se ha clasificado en sus estanterías" (Gallardo, 1915). También aconsejaba que no fueran solo lugares de exhibición o acumulación de objetos sino además centros de estudio de los materiales estrictamente locales, sin tratar de emular las ambiciones globales y las grandes colecciones de los museos metropolitanos.

En la misma época, escritores como Leopoldo Lugones (1913), oriundo de Córdoba, o Ricardo Rojas (1915), nacido en Tucumán y criado en Santiago del Estero, apoyaron la idea de los museos provinciales como instituciones que podían estimular el renacimiento de las industrias locales, en la medida que exhibieran objetos y productos antiguos de la zona. Entre ello, recomendaban la exposición y vulgarización de motivos indígenas y otros tradicionales en la decoración de tejidos, cueros, alfarería y platería, entre otras artes aplicadas que podrían constituirse en representaciones de la naturaleza local y dar una entrada económica para las mujeres rurales. En la década de 1920, esto se combinaría con las exposiciones escolares, las de artes y tejidos y la difusión de motivos indígenas como rasgos representativos de lo autóctono americano y local. Un movimiento apoyado por la Liga Patriótica Argentina y sectores de derecha. 
Las actividades de algunos de estos museos en las provincias incluyeron la organización de muestras oficiales para la presentación de "la alta potencialidad productiva y las grandes riquezas propias de su suelo" en algunas exposiciones nacionales e internacionales. El Museo de Salta, por ejemplo, se organizó como una agencia oficial de propaganda sobre la Provincia y de asesoramiento sobre la potencialidad económica de los recursos del suelo provincial. En otros casos, desempeñaron un papel en la promoción de ciertas localidades como sitios de singular importancia científica o histórica, contribuyendo a ampliar el conocimiento de la distribución de especies animales o vegetales 0 de yacimientos paleontológicos. A través de las colecciones reunidas y los trabajos publicados por los directores y colaboradores se tendió a resaltar las particularidades de la flora, la fauna, los recursos mineros, el paisaje, los sitios de interés histórico o los restos arqueológicos hallados en el territorio provincial y zonas vecinas como parte de lo "autóctono y pintoresco". Con ejemplo de esto último, se puede mencionar los trabajos de los hermanos Emilio y Duncan Wagner, hijos de un diplomático francés, en torno al "descubrimiento" de una "civilización chaco-santiagueña". En 1923, el Consejo de Educación de Santiago del Estero le concede a Emilio Wagner un sueldo de maestro para clasificar las colecciones de Gancedo y dirigir el Museo Arcaico, sumándose posteriormente su hermano como vicedirector. Como menciona Ana T. Martínez, poco después el Museo atravesó diversos avatares, proyectos frustrados y clausura hasta que en 1927, nuevos hallazgos arqueológicos, notas periodísticas y el apoyo de una asociación cultural generaron la reabertura del Museo y subsidios para expediciones. En esos años, se establecieron estrechas vinculaciones entre esta institución y las escuelas locales, a través de visitas al Museo, conferencias sobre arqueología santiagueña y la organización de talleres de alfarería y tejidos, donde se reprodujeron motivos decorativos de piezas arqueológicas, que se volverían motivos emblemáticos de Santiago del Estero. Esto sería celebrado en los periódicos locales como un emprendimiento económico importante y una contribución a la formación de un "arte esencialmente nacional" (Martínez et al., 2003). Los materiales arqueológicos trabajados por los hermanos Wagner alcanzaron una gran difusión en el país y entre especialistas extranjeros, incorporándose como parte de la representación de la provincia. Aunque en el ámbito científico nacional sus interpretaciones y la entidad cultural propuesta fueron muy cuestionadas en la década de 1930, estas sobrevivieron en el universo escolar y en los círculos culturales locales (Martínez et al. 2003; Podgorny, 2004; Gorelik, 2001). 
Cierta revalorización de lo "autóctono" y de los productos e industrias locales fueron elementos recurrentes en las declaraciones oficiales y los discursos de legitimación de los museos provinciales y regionales que se fueron organizando en los siguientes años. A pesar de los objetivos institucionales y las declaraciones oficiales sobre el carácter "regional" de las colecciones, esto no excluyó la existencia de un conjunto heterogéneo de materiales de otros puntos del país o del extranjero, en algunos casos como parte de un sistema de referencias o comparación, pero en su mayor parte como resultado de donaciones, canjes o lo reunido por sus directores en sus viajes. Especialmente en los momentos iniciales, la necesidad de llenar las salas hacia que se aceptaran especímenes de procedencia diversa. También se recibieron piezas muy heterogéneas cedidas por los vecinos y miembros de la sociedad local, aun cuando esos objetos trascendían los objetivos del museo. No obstante, su aceptación podía ayudar a generar nuevas donaciones y a legitimar el museo como un producto colectivo de la sociedad local. Esto último, además, se reforzaba con la publicación de las listas de los donantes. Paulatinamente, con expediciones y el trabajo de recolección de los directores, naturalistas adscriptos, taxidermista y otros asistentes de los museos, sumado al tendido de redes de colaboradores locales, se irían conformando conjuntos cada vez mayores de ejemplares de la fauna, la flora y/o restos arqueológicos. Así, en la década de 1930, los museos educacionales de Paraná y Mendoza se transformarían en museos provinciales de ciencias naturales y antropología, al igual que el de Santa Fe en la siguiente década. Los museos provinciales también intercambiaron objetos y publicaciones entre ellos y con los museos nacionales e instituciones científicas de Buenos Aires y La Plata, por lo que también tendrían materiales de distintos puntos del país.

\section{Redes de recolección local e intercambio nacional}

Los directores de los museos en las provincias, al igual que los "regionales" que se fomentaron en los territorios nacionales y a nivel de los municipios desde mediados de la década de 1930, formaron parte de redes de trabajo jerárquicas, distribuyendo instrucciones y fomentando las prácticas de recolección y envío de ejemplares entre las poblaciones y las escuelas de la región. En la mayoría de los casos, estos coleccionistas del interior del país participaron de amplias redes de intercambio regional y nacional, conformado un eslabón intermedio entre las instituciones nacionales y los ámbitos más locales. De hecho, muchos de ellos mantenían correspondencia, enviaban ejemplares e intercambian 
información o publicaciones con los que se distinguían en el escenario científico nacional e internacional, desempeñando el papel de coordinadores regionales de objetos, información, personas y otros recursos. El control de los objetos dignos de ser coleccionados implicó indicaciones sobre procedimientos, la circulación instrucciones así como una cierta popularización sobre la importancia científica de esos materiales.

Las redes de recolección de muestras de la naturaleza y el pasado local se presentaban como una tarea colectiva modelada por instrucciones circulantes a través de la estructura jerárquica de la administración burocrática, especialmente por medio del sistema escolar y también recurriendo al aparato policial ${ }^{2}$. Para ello se recurría a una forma burocrática muy instalada y utilizada desde la época colonial, como eran las "circulares": formularios, instrucciones o notas de pedido que se distribuían de forma descendiente por la jerarquía burocrática del aparato estatal. Esto, por ejemplo, se puso en práctica en el Museo Regional de Corrientes. En 1921, el director de esta institución solicitó al Ministro de Gobierno para que por su intermedio se mandaran instrucciones de recabar objetos para el Museo a los departamentos de Policía de la capital y las comisarías de campaña. A través de los funcionarios policiales se consiguieron algunas armas y otras piezas que remitían a batallas históricas. Más cantidad de objetos se reunieron a través del sistema escolar: maestros y escuelas remitieron colecciones mineralógicas y piezas arqueológicas e históricas, participando además en el proyecto de conformar un herbario regional. Entre 1922 y 1925 más de 30 escuelas, principalmente rurales, enviaron muestras de plantas, llegándose a formar una colección de 300 especies clasificadas por los especialistas de Buenos Aires y La Plata (Aguilar, 1928). Por su parte, el Museo Escolar Central de Entre Ríos recibió donaciones del personal de cuarenta escuelas de distintos puntos de la provincia entre 1926 y 1927. Asimismo, se obtuvieron monedas antiguas, objetos etnográficos y animales frescos, entre otros materiales donados por estudiantes secundarios, vecinos de Paraná y de otras localidades cercanas. En 1926, por ejemplo, más de 240 personas remitieron objetos al Museo (Serrano, 1927), mostrando la difusión alcanzada por la institución así como la popularización de las prácticas de coleccionismo. Cabe recordar, que la

2 Este recurso fue utilizado por varias instituciones, como por ejemplo, el Museo Etnográfico de la Facultad de Filosofía y Letras de Buenos Aires para el tendido de redes de recolección de piezas entre funcionarios del gobierno y comisarios del noreste del país en la década de 1910 (Pegoraro 2003). Asimismo, la Junta de Historia y Numismática de Misiones recurrió a maestros y policías para reunir objetos del territorio misionero para el Museo Regional organizado en la década de 1940 (Jaquet, 1999). 
base de este establecimiento, así como su desarrollo posterior estuvo ligada a algunas sociedades de aficionados, estudiantes y promotores de las ciencias naturales (Badano, 1947). Sin embargo, el entusiasmo por estas prácticas y el Museo, no alcanzó para que se concretaran las promesas de edificio propio realizadas por algunos intendentes de turno y otros funcionarios.

Como en Paraná, otros museos publicaron cartillas para los coleccionistas aficionados, claves de identificación de la flora local, indicaciones sencillas sobre tratamiento y conservación de pequeños animales, formación de museos escolares y material didáctico, ofreciendo además clases de taxidermia. Los animales de la fauna local preparados en estos cursos, servirían además para ofrecer en canje con otras instituciones. En varios casos se reproducirian las cartillas e instrucciones confeccionadas por los naturalistas del Museo de Buenos Aires y la Sociedad Ornitológica del Plata, fundada en 1916, y publicadas por el Consejo Nacional de Educación y los boletines de educación provinciales.

Al iniciarse la década de 1920, las exposiciones de trabajos prácticos y manualidades de escuelas de las provincias y los territorios nacionales cobraron mucho auge y mostraron el papel que la escuela podía desempeñar en el fomento de nuevas industrias y el aprovechamiento de las riquezas naturales del país. Angel Gallardo, por entonces presidente del Consejo Nacional de Educación, consideró que podía ampliarse: "la misión de la escuela argentina haciendo servir esta vasta organización, esparcida por todos los ámbitos del territorio, como colaboradora en la tarea del reconocimiento científico de las producciones naturales de nuestro suelo a fin de completar el inventario aún imperfecto de nuestra flora, de nuestra fauna y de nuestra gea." (Gallardo, 1921: 69).

Aunque se reconocía las limitaciones y falta de conocimientos técnicos de los coleccionistas "escolares" frente a los especialistas y naturalistas viajeros, los maestros y alumnos presentaban la ventaja del número, del saber local y el "estar alli" durante todo el año, algo importante especialmente para las observaciones sobre florecimiento y fructificación de ciertas plantas así como distribución y abundancia de diversas especies. Así, mientras "el especialista coleccionará mejor ciertas formas raras, el coleccionista escolar recogerá ante todo lo más conspicuo y frecuente y sus observaciones resultarán valiosísimas para dar idea de las plantas más abundantes y que mejor caracterizan la fisonomía de cada localidad. "(Gallardo, 1921: 70). De este modo, los coleccionistas escolares podían ayudar a los grandes institutos científicos en los estudios biogeográficos y a trazar las áreas de dispersión de las diversas especies. 
En particular, Gallardo propuso comenzar con la formación de herbarios regionales. La botánica aparecía como una "ciencia amable" con varias ventajas para la iniciación científica. La recolección de plantas parecía estar al alcance de todos, no requería instrumentos costosos o una preparación especial como las observaciones geológicas ni el empleo de armas ni técnicas de conservación para reunir animales, aparte que esto último podía generar cierta repugnancia o temor en los niños, o "estimular los instintos de crueldad que la escuela procura combatir". En ese sentido, Gallardo, era consciente de las contradicciones que podían generar en los niños las prácticas de recolección: "es cierto que el propósito científico justifica la muerte de unos pocos animales, tanto como las necesidades alimenticias, pero de todas maneras puede crear conflictos de conciencia en el niño la contradicción que para él resulta entre el consejo de respetar los nidos y las aves, por ejemplo, y luego la indicación de cazarlas y coleccionar sus huevos." (Gallardo, 1921: 70-71).

Cabe recordar que en esos años, se estaban difundiendo los programas escolares denominados "Naturaleza", que promovían el estudio y la observación de la naturaleza viva, junto al "amor y respeto" por los animales y plantas, en el marco de un movimiento de protección de la fauna y flora. A pesar de ello, paralelamente se popularizaron instrucciones para que los niños recolectaran insectos, huevos, nidos y otros animales pequeños. Por su parte, los divulgadores de la taxidermia y formación de herbarios aclaraban que estas prácticas, lejos de fomentar hábitos de destrucción de animales o plantas, inculcaban en los estudiantes el amor al estudio de las ciencias naturales, despertando vocaciones por el conocimiento del país y sus fuentes de riqueza. En la década de 1930 se produce una gran popularización de las técnicas y nociones básicas del arte de "conservar animales muertos para que tengan apariencia de vida". Así por ejemplo, en 1934 el curso de taxidermia organizado por el Museo Escolar Sarmiento de Buenos Aires, contó con 345 inscriptos, en su mayoría docentes, y se prepararon más de tres mil ejemplares. Clases de taxidermia y de preparadores también se dictaron en algunos museos provinciales como en Paraná y Santa Fe (Imagen II). 


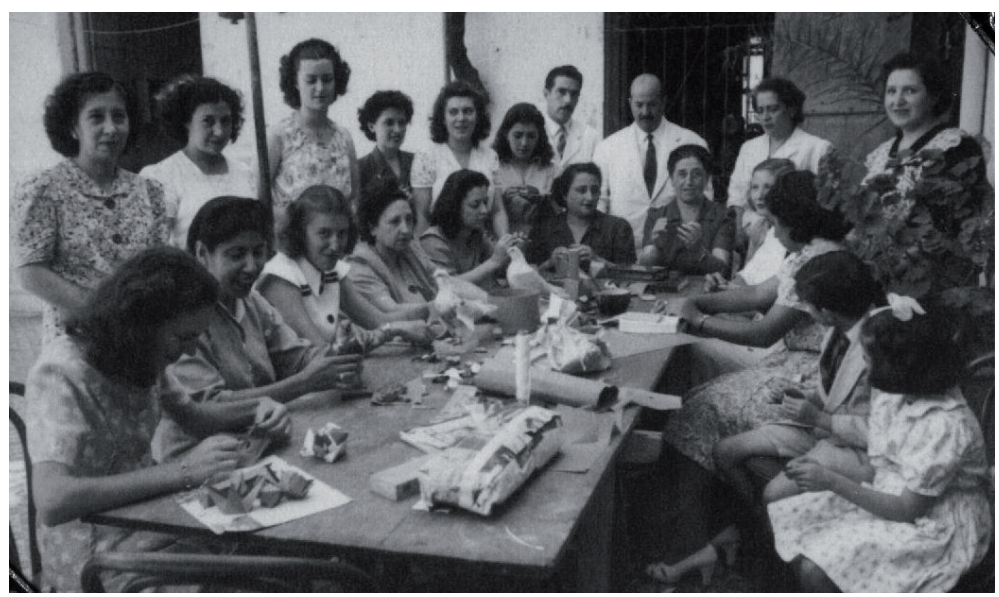

Imagen II: Curso de taxidermia del Museo de Ciencias Naturales "Florentino Ameghino" de Santa Fe. Año 1946.

Muchos maestros y profesores normales participando en la organización de museos en las escuelas y posteriormente en la formación de museos regionales en el interior del país, impulsados desde el Consejo Nacional de Educación durante la década de 1930 y la siguiente (García, 2010), al igual que desde las autoridades educativas y algunos coleccionistas de la Provincia de Buenos Aires (cf. Pupio, 2005). Fue frecuente que una vez creados estos museos se iniciara una campaña de presentación y se entablara comunicación con otras entidades similares del país. Entre ello, se solicitaría a los museos nacionales de Buenos Aires y La Plata reglamentos, fotografías, catálogos y otras referencias que les ayudaran a pensar en la mejor organización de la institución. También pedirian asesoramiento o personal para preparar o montar especimenes, así como publicaciones y colecciones. En varios casos, se observa que cada nueva gestión, desconociendo lo actuado por sus predecesores, insistiría en lo mismo. Los archivos del Museo de La Plata, en cambio, guardaban un registro de lo ya enviado y la colaboración prestada. Las cartas y notas de pedidos archivadas en esta institución, permite observar muchos puntos en común en el desenvolvimiento de esos museos.

Frecuentemente el reconocimiento de objetos o el tratamiento específico de algunas piezas escapaba a las posibilidades y los conocimientos del personal de los museos regionales o de las escuelas. En esos casos se recurría a los especialistas de los institutos científicos de Buenos Aires y La Plata. Los científicos de estas instituciones podía 
acceder así a piezas de cierta importancia científica, pero muchas veces se encontraría con objetos carentes de todo interés como los supuestos fósiles enviados a La Plata por el Museo Provincial de Ciencias Naturales de Córdoba en 1945, que resultaron ser restos de caballos y mulas contemporáneos. En otros casos, los jefes de los departamentos científicos del Museo de La Plata, trataron de dirigir las tareas de recolección de materiales, remitiendo indicaciones sobre los ejemplares a reunir y cómo conservarlos y enviarlos a La Plata. En el caso de especies zoológicas, aconsejaban a las escuelas y museos locales que trataran de enviar dos o tres ejemplares del mismo organismo, así el Museo de La Plata los clasificaría y los sometería a los procedimientos adecuados de conservación, reservándose en compensación aquellos ejemplares de interés y devolviendo los ejemplares duplicados, acondicionados para su exhibición y con su nombre científico. De esta forma, los grandes museos retendrían los ejemplares "raros", las piezas únicas o los lugares de interés para las investigaciones de los científicos, enviando a cambio publicaciones, láminas, calcos u objetos duplicados. En varios casos, parecía que ambas partes se beneficiaban con el intercambio, cuyo significado excedía el de los valores canjeados, para inscribirse en el dominio de lo simbólico, donde podían definirse personajes, instituciones, formas de sociabilidad y estrategias de interacción (cf. Achim, 2010). Las respuestas, los canjes o la colaboración con los grandes museos, otros institutos de investigación y especialistas reconocidos, se mencionaban en las memorias de estos museos regionales o provinciales y ayudaban a legitimar estas instituciones como interlocutores o colaboradores de una empresa científica mayor y a revalidar las actividades de sus promotores.

Los museos de distintas partes del país como parte del mecanismo de reciprocidad enviaban diversos objetos e informaciones sobre hallazgos de restos arqueológicos y piezas fósiles, o también ponía a disposición ciertos recursos para las exploraciones de los museos nacionales. Al mismo tiempo, la posibilidad de obtener fondos, apoyos logísticos u otros recursos para algún estudio especial o trabajo de campo también llevó a que los institutos nacionales interactuaran con las locales. La inscripción en estos circuitos de intercambio y colaboración emerge entonces, como un factor importante en el reconocimiento de estos museos locales o regionales en el contexto nacional. Precisamente, aquello que parece darles legitimidad es su inserción en una red de canje de materiales e información más allá de los ámbitos locales. Cabe señalar que la circulación de objetos y datos no fue unidireccional sino que involucró diferentes mecanismos de 
reciprocidad e intercambio, así como relaciones de asesoramiento y protección hacia algunos corresponsales y museos de diferentes partes del país, aunque también se generaron casos de competencia y conflicto por ciertas colecciones.

En este trabajo apenas se han mencionado algunos aspectos generales a varios museos que se formaron en el interior del país y las vinculaciones con el sistema educativo, base de sustentación de varias de estas iniciativas. Los organizadores de estos museos y colecciones esperaban que esos materiales enseñaran sobre la naturaleza e historia regional, legitimando tanto un sistema de creencias como las prácticas museológicas de estos coleccionistas y estudiosos locales. En ese sentido, el museo sería presentado como un acto de metonimia para una determinada área, como un microcosmos donde estudiantes, estudiosos y turistas podían conocer los especimenes naturales, la historia y las industrias que se podían encontrar en la región. Sin embargo, el análisis de la materialidad de las exhibiciones, de su tan cuestionada estética o el examen de las declaraciones oficiales y de los informes de los directores de estos museos o sus publicistas no conduce directamente a los múltiples modos de ver e interpretar de los visitantes. En ese sentido, el énfasis en las capacidades y misiones a cumplir por estas instituciones no necesariamente habla de la efectividad de los museos para crear hábitos cívicos o imponer significados. Por el contrario, la insistencia en estos discursos pueden más bien remitir a la debilidad de las mismas instituciones y a la necesidad de apelar a dicha retórica para conseguir los apoyos políticos y presupuestos gubernamentales (Podgorny, 2005). Sin duda, permanece como tarea futura para la historiografía, la posibilidad de reconstruir las experiencias de los distintos públicos y el funcionamiento real de estos museos, más alla de sus momentos fundacionales y de los deseos de sus promotores, pero donde es factible observar el rumbo errático de las instituciones estatales de la Argentina.

\section{Reconocimientos}

Los materiales analizados pertenecen al Archivo Histórico y la Biblioteca del Museo de La Plata, a la Biblioteca de la Facultad de Ciencias de la Educación y Humanidades de La Plata y la Biblioteca del Maestro. Agradezco al personal de los Museos de Ciencias Naturales de Santa Fe y de Paraná, por la atención durante mi visita, y a Irina Podgorny por la lectura del trabajo. Este trabajo forma parte de los proyectos de investigación PICT 32111 y PIP 0116. 


\section{Bibliografía}

Achim, M. (2010) "Setenta pájaros africanos por antigüedades mexicanas: canjes de objetos y la formación del Museo Nacional de México (1825-1867)", L'Ordinaire Latino-américain, n²10, pp. 13-32.

Agüero, A. C. (2009): El espacio del arte. Una microhistoria del Museo Politécnico de Córdoba entre 1911 y 1916. Córdoba: Universidad Nacional de Córdoba.

Aguilar, Valentín (1928): El Museo Regional de la Provincia de Corrientes. De 1920 a 1927, Corrientes: Imprenta del Estado.

Badano, Víctor (1947) "Museo de Entre Ríos. Su Origen y desarrollo (19171947)", Memorias del Museo de Entre Ríos, n²7.

Coleman, Laurence (1929): Directory of museums in South America. Washington: The American Association of Museums.

Gallardo, A. (1915): "Museos Regionales", Revista de la Universidad Nacional de Córdoba, II, 6, pp. 395-399

(1918-19): "Los estudios biológicos en la República Argentina". Primera Reunión nacional de la Sociedad Argentina de Ciencias Naturales, Tucumán, 1916. Buenos Aires: Coni, pp: 1-26.

(1921): "Formación de colecciones de productos naturales. Proyecto", El Monitor de la Educación Común, tomo 77, no 578, Sección oficial, pp. 69-71.

García, S. (2007): "Museos escolares, colecciones y la enseñanza elemental de las ciencias naturales en la Argentina de fines del siglo XIX", História, Ciências, Saúde - Manguinhos, vol. 14, nº 1.

(2010): "Museos y materiales de enseñanza en la Argentina, 1890-1940", en: Castilla, A. (comp.): El museo en escena. Poíticas culturales y museos en América Latina, Buenos Aires: Paidós, pp. 91-109.

García, S. y Podgorny, I. (2000) "El sabio tiene una patria. La primera Guerra mundial y la comunidad científica argentina", Ciencia Hoy, vol. $10, n^{\circ} 55$, pp. 24-34. 
Gorelik, A. (2001): "Mapas de identidad. La imaginación territorial en el ensayo de interpretación nacional: de Ezequiel Martínez Estrada a Bernardo Canal Feijóo", Primas, vol. 5, pp. 283-311.

Hicken, C. (1923) Evolución de las ciencias en la República Argentina. VII Estudios Botánicos. Buenos Aires: Sociedad Científica Argentina.

Holmberg, E. A. (1902): "Museos Provinciales y Museos Regionales", Anales de la Sociedad Científica Argentina, pp. 271-274.

Jaquet, H. (1999): Los combates por la invención de Misiones. Un estudio de la participación de los historiadores en la construcción de una identidad para la Provincia de Misiones, Argentina, 1940-1950. Tesis de Maestría, Universidad Nacional de Misiones.

Lugones, L. (1913) "El Museo de Córdoba", La Nación, 15/7/1913.

Martínez, A. T.; Taboada, C. y Auat, L. A. (2003) Los hermanos Wagner: entre ciencia, mito y poesía. Arqueología, campo arqueológico nacional y construcción de identidad en Santiago del Estero, Santiago del Estero: Ediciones Universidad Católica de Santiago del Estero.

Piccirilli, R.; Romay, F. y Gianello, L. (1953) Diccionario histórico argentino, Buenos Aires: Ediciones históricas argentinas.

Pegoraro, A. (2003): "Estrategia de formación de colecciones del Museo Etnográfico durante el período 1904-1917. Funcionarios de Gobierno en la recolección de piezas", en: Lorenzano, C. (ed.), Historias de la Ciencia Argentina I, Buenos Aires: EDUNTREF, pp. 17-28.

Podgorny, I. (2004): "Tocar para creer": La Arqueología en la Argentina, 1910-1940", Anales del Museo de América, №. 12, pp. 147-182

(2005): "La mirada que pasa: museos, educación pública y visualización de la evidencia científica, História, Ciências, Saúde-Manguinhos, v. 12 (suplemento),pp.: 231-264.

(2009): El sendero del tiempo y de las causas accidentales. Los espacios de la prehistoria en la Argentina, 1850-1910. Rosario: Prehistoria.

Podgorny, I. y Lopes, M. M (2008): El desierto en una vitrina. Museos e historia natural en la Argentina. México: Limusa. 
Pupio, Alejandra (2005) "Coleccionistas de objetos históricos, arqueológicas y de ciencias naturales en museos municipales en la provincia de Buenos Aires en la década de 1940", História, Ciências, Saúde-Manguinhos, v. 12 (suplemento), pp.: 205-229.

Rojas, R. (1915): La Universidad de Tucumán. Tres conferencias, Buenos Aires: Librería argentina de Enrique García.

Serrano, A. (1927): Memoria Anual correspondiente a 1926 del Museo Escolar Central de la Provincia y Nómina de Contribuyentes. Paraná. 
7.

\section{Colecciones de cráneos, fotografías y manuscritos en el desarrollo de la antropología física y de la etnografía lingüística en la Argentina a fines del siglo XIX.}

Máximo Farro ${ }^{1}$

\section{"Commercium craniorum"}

Si se toma en consideración la dimensión práctica del trabajo científico se puede señalar que una característica distintiva de la antropología física del siglo XIX fue la necesidad de grandes colecciones de cráneos como condición sine qua non para el trabajo en el gabinete (Dias, 1989). Este último estaba determinado por la necesidad de proceder a hacer observaciones múltiples y variadas sobre vastos conjuntos: solo el montaje de grandes series hacía posible la comparación y el estudio sistemático en el marco de un proceso que suponía que el conocimiento de cada forma de cráneo estuviera subordinada a la de todas las otras formas vecinas. Esta necesidad de grandes colecciones implicó la organización de un esquema de trabajo basado en la separación entre aquellos que recolectan datos en espacios abiertos como el "campo", y los que los compilan e interpretan en espacios cerrados como gabinetes, laboratorios y museos. Para ello los estudiosos europeos y norteamericanos desarrollaron redes de corresponsales alrededor del mundo para la obtención de cráneos representativos de los grupos indígenas de las distintas regiones del globo. A lo largo del siglo XIX y en especial a partir de la década de 1840 se generó así un activo "commercium craniorum"

1 Archivo Histórico del Museo de La Plata, Paseo del Bosque S/N, La Plata. Contacto: mfarro@fcnym. unlp.edu.ar, maximofarro@gmail.com. Este trabajo fue elaborado en el marco del proyecto PIP 0116, dirigido por Irina Podgorny. 
(Cf. Luyendijk-Elshout, 1997) a escala global del que participaron numerosos viajeros y corresponsales que enviaban a los estudiosos de las metrópolis cráneos obtenidos en espacios como los hospitales cercanos a los puertos, las morgues, los cementerios y sobre todo en los campos de batalla. Ejemplos tempranos de este tipo de colaboradores en el Río de la Plata fueron el médico Thomas Hutchinson y el coronel Francisco Borges quienes actuaron como corresponsales del estudioso británico Joseph Barnard Davis que integró los cráneos que le enviaron en su obra Thesaurus Craniorum (1867 y 1875). Borges, que se desempeñaba como Comandante en jefe de las fronteras Norte y Oeste de Buenos Aires y Sud de Santa Fé le envío a Davis, con quien estaba emparentado, ${ }^{2}$ cráneos de indígenas pertenecientes a las tribus de Catriel, Calfucurá y Pincén que había obtenido como producto de los numerosos combates con los indígenas que tuvieron lugar por esos años a lo largo de la línea de frontera a su cargo. Durante esos años uno de los coleccionistas más activos en la obtención de series de cráneos de indígenas de la Pampa, la Patagonia y los valles Calchaquíes fue Francisco Pascasio Moreno (1852-1919). Para ello utilizó su red de relaciones familiares basada en vínculos comerciales y de pertenencia étnica consiguiendo apoyos que se materializaron en el envío de ejemplares por parte de corresponsales, la provisión de recursos económicos, la logística para el desarrollo de expediciones, y la cooperación de los indígenas aliados al gobierno nacional para la obtención de cráneos y esqueletos (Farro, 2009). Moreno actuó como corresponsal de los principales estudiosos europeos, fundamentalmente franceses y alemanes mediante el envío de cráneos y datos que serían integrados a discusiones y esquemas explicativos que variaron de acuerdo a las distintas tradiciones de investigación de cada país. En el caso de Francia, Paul Broca nombró a Moreno como socio corresponsal de la Sociedad de Antropología parisina estimulándolo para que recolectara la mayor cantidad posible de cráneos de la Patagonia con el objeto de que pudieran ser estudiadas in situ utilizando los instrumentos y los protocolos diseñados para ello por el mismo Broca (Podgorny, 2006). Esta necesidad de grandes series para la realización de estudios de antropología física es un aspecto por lo general pasado por alto en los trabajos que consideran la formación de colecciones exclusivamente a partir del papel punitivo desempeñado por el Estado argentino en el dominio del territorio y el sometimiento y exterminio de los grupos indígenas. En efecto, las prácticas de registro y medición con instrumentos sobre vastos con-

2 Borges había contraído matrimonio en 1871 con Frances Anne "Fanny" Haslam y Arnett (1842-1935), hija de Edward Young Haslam (1808-1878) y Jane Arnett; la hermana del suegro de Borges, Elizabeth Haslam (1792-?), era la esposa de Joseph Barnard Davis. Cf. Hadis 2006. 
juntos estaban animadas por la búsqueda de precisión y constituían el paso previo indispensable para el cálculo de distintos índices que una vez compilados hacían posible la comparación entre las series óseas depositadas en repositorios y gabinetes diseminados por el mundo. Así, transformadas en tablas de cifras precisas producto de la aplicación de instrumentos y normas estandarizadas las colecciones de cráneos se constituían en lo que Daston y Galison (2007) han denominado "working objects", pudiendo ser movilizadas trascendiendo el contexto local donde se encontraban depositadas haciendo posible en consecuencia el estudio y la discusión en el ámbito internacional. Con esos datos que circulaban en forma de tablas se definieron "tipos" raciales obtenidos mediante la operación intelectual de abstraer determinados rasgos que lo definían en contraposición a otros. En la determinación de esos tipos y en la clasificación posterior de los mismos, la idea de "Nación" y el concepto de "nacionalidad" asociados a las prácticas de control social por parte del Estado, no desempeñaba papel alguno.

\section{Las colecciones de fotografías y su uso en las clasificaciones raciales}

En el transcurso de la última década nuevos estudios referidos a la fotografía antropológica han centrando la atención en los atributos físicos de las imágenes integrando al análisis la dimensión material. De ese modo han recuperado los contextos de producción, intercambio y consumo de las colecciones de imágenes destacando sus usos sociales a partir de considerarlas como objetos que circulan por redes de intercambio ligadas a las prácticas de colección, archivo y exhibición (Edwards, 2001, Edwards y Hart 2004). Desde este punto de vista, se puede afirmar que en la antropología física del último tercio del siglo XIX la fotografía ingresó en el repertorio de las prácticas de laboratorio como una técnica auxiliar a la toma de mediciones sobre colecciones y sobre individuos, y como complemento a la observación de los rasgos fisonómicos a partir de imágenes tomadas de frente y de perfil siguiendo protocolos estandarizados (Dias, 1994). En ese sentido era de utilidad para el registro de los llamados "caracteres físicos descriptivos" que eran criterios distintivos para la clasificación de las razas humanas basados en la observación directa de rasgos fisonómicos y corporales sobre individuos vivos. En ambos casos, las colecciones de fotografías desempeñaron un papel secundario siendo entendidas como complemento de las series de cráneos y esqueletos, y fueron utilizadas para agregar evidencia en el proceso de establecimiento de filiaciones y relaciones generales entre grupos raciales 
a partir de la determinación de "tipos" (Edwards, 2001). Esto hizo posible tanto el desarrollo de estudios comparativos en el gabinete como el diseño de exhibiciones que dieran cuenta de los mismos. Un ejemplo de esto lo constituyen los álbumes que el príncipe Roland Bonaparte armó con retratos de frente y de perfil y con fotografías de cuerpo entero de distintos grupos indígenas tomados en el transcurso de exposiciones realizadas entre 1883 y 1884 en Londres, París, Amsterdam y Berlín. Copias de estos álbumes fueron donadas por Bonaparte a los estudiosos y a las instituciones dedicadas a la antropología alrededor del mundo, siendo el director del Museo de La Plata, Francisco P. Moreno uno de los tempranos receptores, hacia 1884. Poco después Moreno contrató al fotógrafo Samuel Boote (1844-1921) para que realizara retratos de frente y de perfil de los indígenas de las tribus de Inacayal y Foyel que habían sido tomados prisioneros por parte del Gobierno nacional (Vignati, 1942). Esos retratos son muy similares en su composición a los realizados por Bonaparte y fueron montados sobre placas de cartón con inscripciones referidas a la probable adscripción étnica a la manera de los álbumes donados por aquel. Posteriormente los retratos fotográficos de tehuelches y araucanos fueron colocados la sala de exhibición de la Sección Antropológica del Museo junto a quince retratos al óleo realizados a partir de esas copias por el pintor italiano Luis de Servy. ${ }^{3}$ En relación con esto último nos interesa destacar un dato a menudo soslayado: Moreno había visitado durante una estadía en Europa entre 1880 y 1881 los más importantes museos y exhibiciones de carácter antropológico y estaba al tanto de los últimos avances en lo referido a modos de organización y exhibición de las colecciones. En efecto, gran parte de las exhibiciones que visitó se caracterizaban por contener grandes series de cráneos y de esqueletos acompañadas por bustos de indígenas realizados en yeso, cera y bronce, moldes de cráneos, mascarillas faciales, óleos, acuarelas, daguerrotipos y fotografías que ilustraban los tipos raciales de todo el mundo. Siguiendo el ejemplo de estas instituciones Moreno agregó a la exhibición de colecciones de cráneos y esqueletos en la sección antropológica del Museo de La Plata, una serie de fotografías, acuarelas y dibujos de tipos indígenas de la América meridional, en especial de los grupos de los territorios de Bolivia, Perú, Chile y la Argentina. Posteriormente, estas colecciones de fotografías fueron utilizadas por el primer encargado de la sección, Herman F.C. ten Kate (1858-1931) quien por su formación práctica en los laboratorios de antropología de Francia y Alemania estaba al corriente de

3 Boleta por trabajos de pintura de Luis de Servy, 4 de abril de 1887, en Archivo General de la Nación, Legado Moreno, Legajo I, № 3096. 
este uso tipológico de las imágenes y participaba también activamente en las redes de intercambio de materiales actuando en ocasiones como corresponsal de los antropólogos de la comunidad internacional. ${ }^{4}$ En este esquema de reciprocidad las copias fotográficas, en tanto soporte material de datos en bruto, funcionaban como un vehículo de comunicación entre los estudiosos y los distintos círculos de individuos dedicados a la antropología quienes las coleccionaban para formar acervos que permitían posteriormente la realización de estudios raciales comparativos a escala global. Durante sus años en La Plata, ten Kate aumentó estas colecciones con nuevas fotografías de individuos representativos de los grupos Araucanos, Tehuelches, Guayaquíes, Calchaquíes y Chiriguanos. Para ten Kate estas series de fotografías del Museo agregaban evidencia visual a una de las ideas que sostuvo con firmeza a lo largo de los años referida a las relaciones de filiación de los grupos indígenas del continente americano. En efecto, al igual que Rudolf Virchow ten Kate sostenía la idea de la pluralidad de tipos raciales en América, más que la existencia de un tipo universal, común y autóctono, de "indígena americano" como lo sostenía Daniel Brinton (Brinton, 1891, ten Kate 1892). Para completar su posición, a la diversidad de tipos estimados a partir de mediciones y cálculos de distintos índices ten Kate agregó la identificación visual de caracteres "mongoloides" en los grupos americanos, lo que implicaba colocarlos en la clasificación racial bajo el rótulo de las llamadas "razas amarillas" junto con los malayos, los polinésicos y con las poblaciones mongólicas de Asia. Las colecciones de imágenes permitían apreciar las similitudes somáticas que daban cuenta de la fisonomía general de los grupos americanos y mongoloides a partir de la comparación del desarrollo y las proporciones generales del cuerpo, el tipo de piel, la forma de la nariz y de los ojos, los tipos de cabello y el grado de prognatismo. Como corolario, nos interesa remarcar nuevamente aquí la idea de que las colecciones de fotografías -como las de máscaras, bustos, moldes, pinturas y dibujos- funcionaban como complemento de las series de cráneos y de esqueletos y de las mediciones que se registraban sobre estas. En ese sentido, las colecciones de fotografías pueden ser entendidas como una pieza más un "dispositivo de observación" producto de la búsqueda de un nuevo lenguaje numérico y visual para la antropología del siglo XIX siendo utilizada por los estudiosos como vehículos para ilustrar en el ámbito de las exhibiciones las ideas referidas a los distintos esquemas de clasificación racial (Dias, 1998).

4 Acerca de los trabajos de fotografía antropológica que el sucesor de ten Kate, Robert LehmannNitsche, realizó junto a Carlos Bruch para el Museo de La Plata hacia comienzos del siglo XX véase la tesis doctoral de Alejandro Martínez. 


\section{Las lenguas indígenas americanas como objeto de colección}

Los estudios sobre las lenguas indígenas americanas fueron circunscriptos dentro del campo de las "ciencias históricas" conformando una corriente dedicada al establecimiento de una "etnografía lingüística" que tuvo su auge sobre todo en la última década del siglo XIX con las obras de Daniel Brinton en los Estados Unidos y de Lucien Adam en Francia (Dias y Rupp-Eienreich 2000). Una parte importante del trabajo consistió así en la recolección y revisión de datos para hacer descripciones de las estructuras gramaticales y clasificaciones de las lenguas por familias, en detrimento de la reflexión teórica (Auroux, 2000). En ese contexto, Samuel Alexander Lafone Quevedo (1835-1920) desarrollará estudios lingüísticos basados en la publicación de ediciones críticas de manuscritos y "obras raras" referidas a aquellas lenguas indígenas de la América meridional de las que existían abundantes testimonios en el territorio argentino. Residente en la provincia de Catamarca y nombrado por Moreno en 1888 como encargado honorario de la Sección de Lenguas Americanas del Museo de La Plata, Lafone Quevedo realizó así un trabajo de compilación de fuentes manuscritas en los archivos locales y registró vocabularios a partir de informantes indígenas que habitaban en la región, con el objeto de confeccionar un Vocabulario o "Thesaurus" Catamarcano referido a la lengua Cacana de los antiguos Diaguitas. También relevó información en las bibliotecas y colecciones de manuscritos del general Bartolomé Mitre (1821-1906) referidos fundamentalmente a las lenguas y dialectos indígenas del Chaco. Con ese material comenzó a bosquejar un esquema de clasificación de las lenguas indígenas basándose en un rasgo gramatical específico que estaba asociado a una forma particular de aglutinación que para él era propia del continente americano, como son las partículas pronominales y sus formas de articulación tanto con los verbos como con los nombres (Lafone Quevedo, 1893). La recolección de evidencia para fundamentar este esquema clasificatorio implicó un riguroso proceso de extracción, registro y organización de los datos a partir de un corpus o colección de manuscritos con transcripciones y de vocabularios impresos con el objeto de convertirlos en series útiles para el trabajo de comparación de las formas de colocación de las partículas pronominales entre las distintas lenguas y dialectos. Con la ayuda de un escribiente Lafone Quevedo organizó así una colección con transcripciones de vocabularios formada por cuadernillos donde se ordenaban alfabéticamente las entradas, asentando en una columna los vocablos en idioma indígena 
y en una columna contigua sus equivalentes en castellano. En relación con esto nos interesa destacar aquí una observación que realizara en 1875 el estudioso norteamericano William Dwight Withney (1827-1894) que se refiere precisamente a esta dimensión material del lenguaje y su relación con las prácticas asociadas al armado de colecciones para los estudios de clasificación y comparación. Mediante su transcripción a un sustrato de papel -afirmaba Withney-, las lenguas podían transformarse en un objeto pasible de ser almacenado, clasificado y estudiado comparativamente a la manera de los especimenes que componen las colecciones de historia natural. ${ }^{5}$ La colección de vocabularios y manuscritos armada por Lafone Quevedo estaba compuesta por una serie de cuadernillos preparados y editados sistemáticamente con rótulos y siglas específicas, de manera tal que fueran no solo fácilmente transportables y almacenables sino para que facilitaran el trabajo de transcripción y comparación posterior entre las raíces de las distintas lenguas, pudiendo colocarse un cuadernillo junto a otro y cotejar las posibles similitudes y diferencias. Para aumentar estas colecciones con nuevos datos Lafone Quevedo publicó unas instrucciones para la recolección de vocabularios referidos a las lenguas indígenas (Lafone Quevedo, 1892) urdiendo en pocos años una red de colaboradores en el campo formada mayormente por misioneros de distintas ordenes religiosas que residian en las provincias de Salta, Catamarca, Jujuy, Corrientes y el territorio del Chaco y las regiones fronterizas con Bolivia. También estableció relaciones con el comerciante y explorador italiano Guido Boggiani (1862-1902) quien residía en la región del Chaco paraguayo. Estos corresponsales le enviaban a Catamarca información sobre las lenguas indígenas en formas de vocabularios, listas de las partículas pronominales en uso y, en el caso de los misioneros de las distintas ordenes religiosas, transcripciones de documentos de sus archivos. Lafone también les solicitó información acerca de la ubicación y dispersión geográfica que en ese momento tenían los distintos grupos hablantes para poder cotejarlos con los datos que había relevado en las obras producidas desde el siglo XVI y que tenía registrados en su colección de vocabularios y manuscritos. De ese modo, articuló con sus corresponsales un esquema de trabajo para el intercambio de datos que remite a la forma de "etnografía epistolar" definida por

5 "Une agglomération de sons venant à former un mot est presque autant une entité objective qu'un polype ou qu'un fossile. On peut la déposer sur une feuille de papier, comme une plante dans un herbier, pour l'examiner à loisir", Withney, 1875: 256. Sobre la analogía entre el manejo de colecciones de historia natural y de colecciones de documentos en el Río de la Plata en relación con el problema de la definición de los límites del país en el siglo XIX, véase Podgorny $2010 \mathrm{~b}$. 
George W. Stocking (1995) para la antropología del siglo XIX, donde los estudiosos dependían de la información de primera mano que podían recolectar especialmente aquellos colaboradores que residían próximos a los grupos indígenas. Lafone Quevedo erigió así una suerte de nodo en una red por donde circulaban datos lingüísticos en forma de manuscritos, cartas y publicaciones, red que articulaba los espacios de su estudio y biblioteca en Catamarca -donde residió de manera permanente hasta 1898-, con los emplazamientos institucionales en Buenos Aires y La Plata, con las regiones donde estaban radicados sus corresponsales y con los estudiosos de las lenguas indígenas americanas residentes en el extranjero, como en el caso de Lucien Adam. Con la información así recolectada y sistematizada en colecciones, pudo desarrollar sus trabajos de etnografía lingüística cuyo fin era el establecimiento de una "geografía histórica" de las lenguas indígenas de la región del Chaco, y cuyo límite cronológico era el período que abarcaba desde mediados del siglo XVI hasta fines del siglo XIX inclusive (Lafone Quevedo, 1899).

\section{Observaciones finales}

Numerosos trabajos han consolidado la idea que sostiene que la antropología en la Argentina de fines del siglo XIX habría desempeñado un papel instrumental tanto en el proceso de dominio territorial por parte del Estado argentino como en la "construcción simbólica de la nacionalidad". Los temas abordados en este trabajo nos dan una visión más matizada del papel desempeñado por la antropología en ese período abriendo nuevos interrogantes y líneas de indagación a partir del análisis de lo que constituyó la cultura material y de las prácticas asociadas a ella, en los campos de la antropología física y de la "etnografía lingüística" de fines del siglo XIX. Entre ellos podemos señalar la escala internacional del trabajo científico (Cf. discusión en Podgorny 2010 a) en los estudios comparativos que implicaba el establecimiento de relaciones entre actores que habitaban mundos sociales diversos. Los intercambios de colecciones de cráneos que realizara Moreno con los estudiosos europeos muestra precisamente la división de tareas que se dio en el marco de la organización del trabajo científico a lo largo del siglo XIX señalando la manera en que los cráneos y datos que aquel enviara -y no sus ideas antropológicas sobre la antigüedad del hombre en América del Sur, como habitualmente se señala-, fueron integrados en las discusiones europeas sobre los tipos raciales del continente americano. Esto se puede apreciar también en los trabajos de clasificación 
que realizó ten Kate utilizando como complemento las colecciones fotográficas del Museo de La Plata, donde identificó una serie de caracteres raciales definidos como "mongoloides" que agregaron evidencia a sus ideas referidas a las relaciones de filiación entre los grupos indígenas del continente americano con las "razas amarillas" del Asia oriental y del Pacífico. De ese modo tanto las colecciones de cráneos como las de fotografías antropológicas sirvieron como insumo para la definición de "tipos" raciales obtenidos mediante la operación intelectual de abstraer determinados rasgos que lo definían en contraposición a otros. En la determinación de esos tipos y en la clasificación posterior de los mismos, la idea de "Nación" asociada a la consolidación del aparato estatal no desempeñaba papel alguno. Por otro lado, el proceso de montaje de colecciones de cráneos y de recolección de datos lingüísticos ejemplificados con los casos de Moreno y Lafone Quevedo respectivamente, demuestran el peso que hacia fines del siglo XIX tenían aun las relaciones interpersonales y las redes de familiares estructuradas en torno al comercio y la pertenencia étnica, vínculos estos que distan de las relaciones de carácter impersonal que caracterizan a la estructura burocrática del Estado. Por último y en sintonía con otros trabajos referidos a los casos de la aqueología prehistórica y la paleontología (Cf. Podgorny 2010 a) nos interesa remarcar las implicancias que se derivan de un enfoque histórico que tome en consideración las prácticas desarrolladas en espacios específicos a partir de colecciones de objetos como las series de cráneos, fotografías y manuscritos, señalando la centralidad de procesos asociados a la construcción de datos, la circulación, las relaciones interpersonales, la movilidad y el intercambio. En ese sentido, los patrones de circulación de estas "cosas-en-movimiento" (Appadurai, 1986; Secord, 2004) permiten iluminar algunas zonas aun poco exploradas en las historias de la antropología física y la etnografía lingüística en la Argentina. 


\section{Bibliografía}

-Appadurai, Arjun (ed.) 1986 The Social Life of Things: Commodities in Cultural Perspective. Cambridge: Cambridge University Press.

-Auroux, Sylvain 2000 "Introduction. Émergence et domination de la grammaire comparée", en Auroux, Sylvain (dir) Histoire des idées linguistiques. L'hégémonie du comparatisme, tomo III. Belgique: Pierre Mardaga éditeur, p. 9-22.

-Brinton, Daniel G. 1891 The American Race. A Linguistic Classification and Ethnographic Description of the Native Tribes of North and South America. New York: N.D.C. Hodges.

-Daston, Lorraine y Galison, Peter 2007 Objectivity. Brooklyn, New York: Zone Books.

-Dias, Nélia "Séries de crânes et armée de squelettes: les collections anthropologiques en France dans la seconde moitié du XIX siècle", Bulletin de la Société d'Anthropologie de Paris, n.s., tomo 1, no 3-4 (1989): 203-230.

-Dias, Nélia "Photographier et mesurer: les portaits anthropologiques", Romantisme, Vol. 24, № 84 (1994): 37-49.

-Dias, Nélia 1998 "The visibility of difference: nineteenth-century French anthropological collections", en: Macdonald, Sharon (ed.) The Politics of Display. Museums, Science, Culture. London and New York: Routledge, pp. 36-52.

-Dias, Nélia y Rupp-Eisenreich, Britta "Linguistique et anthropologie physique", en Auroux, Sylvain (dir) 2000 Histoire des idées linguistiques. L'hégémonie du comparatisme, tomo III. Belgique: Pierre Mardaga éditeur, p. 279-294.

-Edwards, Elizabeth 2001 Raw Histories. Photographs, Anthropology and Museums. Oxford: Berg Publishers.

-Edwards, Elizabeth y Hart, Janice (eds) 2004 Photographs, Objects, Histories. On the Materiality of Images. London: Routledge. 
-Farro, Máximo 2009 La formación del Museo de La Plata. Coleccionistas, comerciantes, estudiosos y naturalistas viajeros a fines del siglo XIX. Rosario: Prohistoria ediciones.

-Hadis, Martin 2006 Literatos y Excéntricos. Los ancestros ingleses de Jorge Luis Borges. Buenos Aires: Editorial Sudamericana.

-Lafone Quevedo, Samuel A. "Instrucciones del Museo de La Plata para los colectores de vocabularios indígenas", Revista del Museo de La Plata, tomo III (1892): 401-416.

-Lafone Quevedo, Samuel A. "La Raza Americana de Brinton. Estudio Crítico", Boletín del Instituto Geográfico Argentino, tomo XIV (1893): 505-528.

-Lafone Quevedo, Samuel A. "Progresos de la Etnología en el Río de la Plata durante el año 1898", Boletín del Instituto Geográfico Argentino, tomo XX (1899): 1-64.

-Luyendijk-Elshout, Antoine M. "Opening Adress: the Magic of the Skull. 'Commercium craniorum' in the Nineteenth Century", International Journal of Osteoarchaeology, Vol. 7 (1997): 571-574.

-Martínez, Alejandro Imágenes fotográficas sobre pueblos indígenas. Un enfoque antropológico. (tesis doctoral inédita).

-Podgorny, Irina "La derrota del genio. Cráneos y cerebros en la filogenia argentina", Saber y Tiempo, Vol. 20 (2006): 63-106.

-Podgorny, Irina 2010 a El sendero del tiempo y de las causas accidentales. Los espacios de la prehistoria en la Argentina, 1850-1910. Rosario: Prohistoria.

-Podgorny Irina "Fronteras de papel: archivos, colecciones antropológicas y la cuestión de límites en las naciones americanas", 2010 b (manuscrito).

-Secord, James "Knowledge in Transit", Isis, Vol. 95, № 4 (2004): 654672.

-Stocking, George W. 1995 After Tylor. British Social Anthropology, 18881951, Madison, Wisconsin, The University of Wisconsin Press. 
-Ten Kate, Herman F.C. 1892 "Sur la question de la pluralité et de la parenté des races en Amérique", Compte-rendu du huitième Congrès International des Americanistes, Paris 1890. París: Ernest Leroux, pp. 288-294.

-Vignati, Milcíades Alejo "Iconografía aborigen I. Los caciques Sayweke, Inacayal y Foyel, y sus allegados", Revista del Museo de La Plata, Nueva Serie, Antropología II, № X (1942): 13-48.

- Whitney, William D. 1875 La vie du langage. Paris: Germere Baillière. 


\title{
Coleção Temática de Plantas Medicinais um espaço de interlocução com a sociedade
}

\author{
Yara Lucia de Oliveira Britto ${ }^{1}$
}

O desejo de organizar e classificar objetos e seres acha-se fortemente relacionado ao desenvolvimento do ser humano, sendo que o reino vegetal não escapou a esse anseio do Homem. Assim a reunião de espécies vegetais em coleções ex-situ ${ }^{2}$ está na a base da origem dos cerca de 1846 jardins botânicos distribuídos em 148 países em diferentes continentes. Sendo mantidas por nestas Instituições, mais de quatro milhões de plantas, distribuídas em coleções vivas, em cujos acervos existem representantes de mais de 80.000 espécies de habito e habitat diferenciados. ${ }^{3}$

Os jardins botânicos e arboretos ${ }^{4}$ são definidos por Donelly e Feldman (s.l., s.d., mimeo) como museus vivos de coleções de plantas, apresentam uma diversidade tipológica de acordo com diferentes características como a vinculação a instâncias governamentais, privadas ou a temática de suas coleções segundo (HEYWOOD, 1990, p.6).

Estas instituições sofreram modificações ao longo do tempo, num processo de desenvolvimento histórico e científico, refletem o contexto sócio-político de cada período, acompanhando as diferentes épocas e finalidades da sua criação. Assim o estudo científico das plantas desenvolve-se em função dos objetivos da sua missão e metas propostas pela

1 Instituto de Pesquisas Jardim Botânico do Rio de Janeiro.

E-mail: ybritto@jbrj.gov.br

2 Por "coleção ex-situ" se entende uma coleção de recursos fitogenéticos com diferentes propósitos mantida fora de seu habitat.

3 Destaca-se que $60 \%$ de todas as espécies de plantas e animais estão concentradas em apenas 1,4\% da superfície terrestre, sendo as florestas tropicais as mais ricas em biodiversidade (NORMAS ..., 2004, p. 34).

4 Coleção ex-situ de espécies vivas de porte arbóreo. 
produção de conhecimento vigente, como evidenciado após a análise das missões de jardins botânicos como: Adelaide Botanical Garden - Austrália, Royal Botanic Gardens - Kew, Missouri Botanical Garden USA, Royal Botanical Gardens- Ontário-Canadá e Jardim Botânico do Rio de Janeiro - Brasil.

Ora divergindo ou convergindo, os jardins botânicos contemplam em suas complexas e diversas missões além da conservação, metas como: incremento do conhecimento, compreensão e interpretação do reino das plantas, descobrir e compartilhar conhecimento, promover e divulgar ensino e pesquisa. Todas apontam para uma inequívoca alusão do seu papel de interlocução e diálogo com a sociedade, objetivando despertar a consciência e a alteração de comportamento frente às questões ambientais, devendo estes se destacar como centros de difusão científica e tecnológica sobre a conservação da biodiversidade.

"Os jardins botânicos tem uma oportunidade, mais do que isto uma obrigação que é aberta apenas para eles de construir uma ponte das preocupações da biologia sistemática tradicional e o retorno das necessidades da agricultura, floresta e a exploração das medicinais com finalidade de conservação da diversidade biológica. A comunidade científica precisa reconhecer que um jardim botânico não é uma academia de luxo ou um espaço para nostalgia. É responsabilidade dos jardins a conservação e o movimento da conservação é o seu papel estratégico" (HEYWOOD, 1990, p.214).

Dentre as coleções vivas gerenciadas por estes jardins, merecem destaque as coleções temáticas ${ }^{5}$ que podem propiciar uma maior interação com o público na medida em que apresentam um universo mais reduzido de espécies vegetais agrupadas segundo um determinado conceito ou por alguma similaridade, sendo, portanto, passível de ser trabalhado de múltiplas perspectivas e interpretações com potencial para ampliar produção de sentido pelo público.

5 Coleções categorizadas com propósitos educativos, pesquisas, interesses etnobotânicos, demonstração de habitat, interesse econômico ou um grupo de plantas (LEADLAY, ETELKA; GREENE, JANE.1999, p.34) 
A coleção de plantas medicinais ${ }^{6}$ vista como uma coleção temática apresenta ainda uma característica que potencializa a interação com o público: o princípio que norteia seu agrupamento constitui uma significação passivel de apropriação pelo senso comum, ou seja, a característica medicinal atribuída pela ciência às plantas constitui também uma atribuição da tradição popular no seu uso cotidiano. Na realidade, a medicina oficial incorpora novas plantas no seu arsenal terapêutico em função da comprovação científica dos saberes culturais, e ainda muitas vezes, mesmo sem esta prova, oficializa o que é consagrado e consolidado pelo uso tradicional. Este procedimento é uma via de mão dupla: valida o conhecimento recebido de uma comunidade e o devolve de modo ampliado disponibilizando-o para um maior número de usuários.

Outro aspecto relevante desta coleção vem a ser a possibilidade de reagrupamento das plantas em função de atributos específicos como o uso por grupos tradicionais, a maneira como os "remédios" são propinados pelos diferentes grupos sociais ou em função da alimentação, da apropriação cultural, dentre outros. Esta coleção destaca-se também pela possibilidade de serem trabalhadas temáticas transversais como a questão da ética, repartição de benefícios, da preservação para obtenção de novos medicamentos, modelos para síntese de medicamentos, descobertas de novas moléculas ou um enfoque sobre os saberes populares.

Contudo, de uma maneira geral as coleções temáticas nos jardins botânicos não foram ainda exploradas em sua potencialidade, com a agregação de novos valores e conceitos provenientes dos olhares de outros saberes.

\section{Virando do avesso}

A natureza e a multiplicidade das questões que envolvem o tema plantas medicinais induzem a busca por novos parceiros que possam agregar novos olhares e, sobretudo, quebrar o isolamento no trabalho institucional.

Um novo contexto possibilitou estabelecer uma parceria públicoprivada objetivando repensar a Coleção de Plantas Medicinais do Instituto de Pesquisas Jardim Botânico do Rio de Janeiro. Desta forma,

6 Esta coleção acha-se representada na quase totalidade dos jardins botânicos e em muitos se constitui na base da sua origem. 
estavam dadas as condições para o desenvolvimento de uma nova proposta conceitual que contemplasse não só aspectos biológicos, mas, sobretudo, aspectos comunicacionais, transformando a coleção num espaço de convivência, garantindo uma maior interlocução e interação com o público visitante.

O aporte financeiro possibilitou a elaboração de um novo projeto que contemplasse a reestruturação do espaço físico, melhoria da infraestrutura, de condições biológicas e novo layout para os diferentes suportes, escolhidos de modo a incrementar e ampliar a comunicação com o usuário.

\section{Montando o quebra-cabeça}

Esta coleção tem como diferencial o estabelecimento de uma linha conceitual que norteia as ações desenvolvidas. Para tal foi elaborado um mapa mental tendo como base o mapa utilizado por Maryke Honig (2005.p.14), que explora a relação das plantas em nossas vidas apontando, desta forma o fio condutor desta proposta. Para o estabelecimento da linha norteadora do conceito a ser desenvolvido, buscou-se encontrar uma palavra que fosse capaz de dar conta da complexidade e abrangência das questões que estão relacionadas com plantas medicinais.
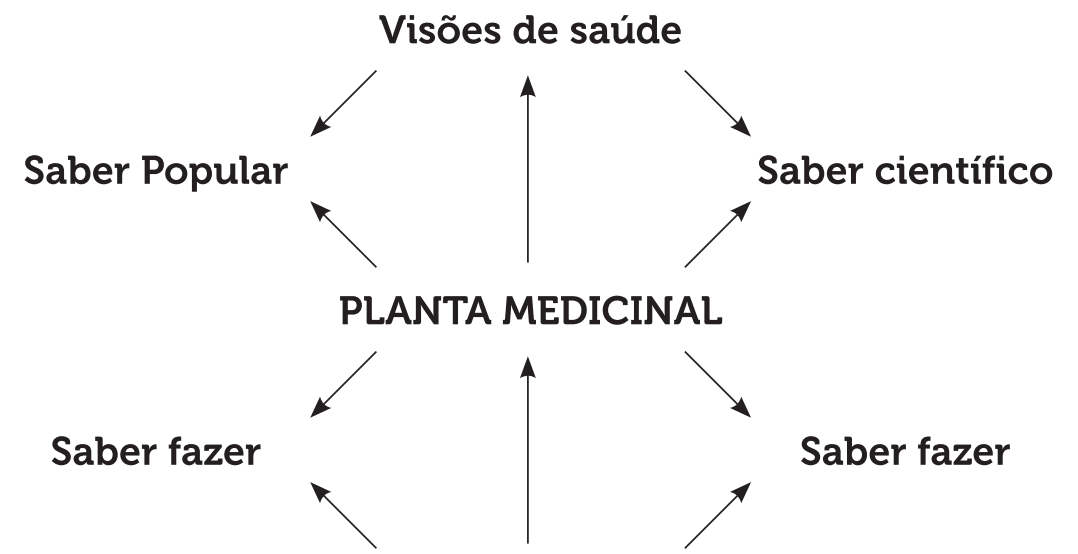

\section{Cultura}

Figura 1: Mapa mental simplificado 
Diversidade foi a palavra encontrada, e aqui entendida no sentido biológico (diversidade de famílias, gêneros, espécies, habitat, habito, distribuição geográfica, compostos químicos entre outros) e cultural na forma de usos, crenças, lendas e mitos, como mencionado por Diegues e Arruda (2001, p.15):

A diversidade biológica, no entanto, não é simplesmente um conceito pertencente ao mundo natural. É também uma construção cultural e social. As espécies são objetos de conhecimento, domesticação e uso, fonte de inspiração para mitos e rituais das sociedades tradicionais e, finalmente mercadoria nas sociedades modernas.

A proposta do projeto orientou-se por abranger a complexidade das plantas medicinais, que envolve não apenas o mundo natural, a diversidade biológica como a sociedade que desde os primórdios trava relações identitárias com a natureza e constrói a diversidade cultural como afirma Diegues e Arruda (2001, p.15)

A criação de um Conselho Curador interdisciplinar foi um diferencial neste processo, pois permitiu o dialogo a participação efetiva nas diferentes etapas da implantação da proposta.

A análise das missões e metas dos jardins botânicos mencionados aponta para a inequívoca alusão do seu papel de interlocução com papel de interlocução e diálogo com a sociedade, objetivando despertar a consciência e a alteração do comportamento frente às questões ambientais, servindo em última instância a sociedade. Neste sentido foi possivel fazer um paralelo com o "Centro de Ciência" termo caracterizado por Elis $(2002$, p.19) relacionando os objetivos que direcionam:

Aumentar o interesse das pessoas pela ciência refor-
çando seu entendimento de modo a construir uma
cidadania mais informada e capaz de tomar melho-
res decisóes; transmitir informações cientíicas,
explicar que a ciência e a tecnologia são atividades
e explicar como estas afetam as vidas das pessoas;
apresentar os fenômenos científicos e objetos de
natureza rara.

Foi possível encontrar pontos de convergência entre Centros de ciência e jardins botânicos e tratar a coleção com uma abordagem expositiva embasada nos objetivos descritos por Elis (2002 p.19), amplificar os objetivos institucionais e dar respostas as questões da coleção 
e inserir aspectos das novas políticas públicas para Plantas Medicinais, incorporada nos dias atuais nos sistemas oficiais de saúde através da fitoterapia.

\section{Por trás dos portões}

O totem de abertura representa o côncavo e o convexo o yin e o yang, a complementaridade dos saberes contido no título da exposição "Plantas Medicinais: olhares e saberes diversos" tem a forma de uma elipse dividida no seu eixo longitudinal e ligeiramente deslocada, De um lado o texto de abertura sintetiza a abordagem da exposição do outro o visitante é saudado por um poema do Wally Salomão, reforçando a questão que se manifesta de inicio, a existência de duas fontes de saber, da ciência e da cultura dispostas lado a lado.

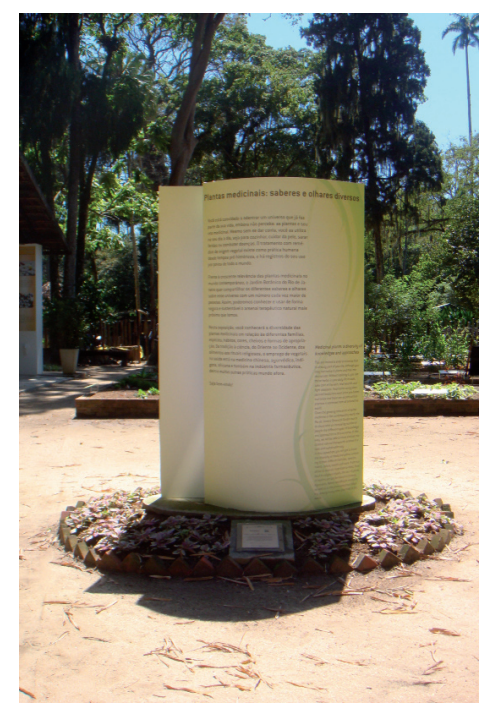

Foto 1: Totem de abertura

O percurso inicial coloca o visitante no centro do seu cotidiano com o tema "Saúde \& Cotidiano" que contempla o conceito de saúde adotado pela OMS entendido como o bem estar físico e espiritual. 
Os canteiros são dotados de títulos e placas textuais informando ao visitante, numa uma linguagem de fácil compreensão o tema tratado. Este espaço é constituído por três canteiros: "Lavar a alma" que aborda aspectos culturais do uso das plantas para promover a saúde do espírito, "Saúde \& Beleza" trata das plantas usadas no corpo como forma de bem estar e estética e o "Tempero da Vida" aborda o uso cotidiano das plantas para realçar sabores e que desempenham papel auxiliar nas funções do corpo humano.

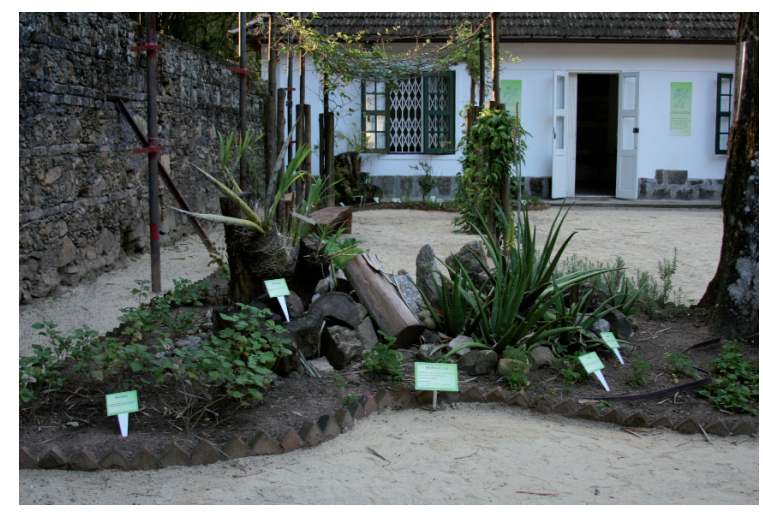

Foto 2: Espaço Saúde \& Cotidiano

A temática do segundo espaço formado por quatro canteiros trata do binômio Ciência e Cultura: no canteiro na "Boca dos Povos" evidencia-se as diferentes nomenclaturas que incorporam e refletem valores de cada grupo cultural. Os exemplares são identificados por placas que contem o nome popular, científico, indígena e yoruba dispostos lado a lado. No canteiro "Lendas e Mitos" as placas textuais contemplam fragmentos de lendas ou trechos literários usados para explicar um fenômeno biológico ou retratar um costume de uma época.

No espaço denominado "Tradição" foram dispostas as plantas cujo atributo consiste no uso consagrado pela população. Ao seu lado o canteiro "Ciência e Novas Descobertas" as plantas possuem diferentes níveis de estudo científicos, bem como já com solicitação de novas patentes. 


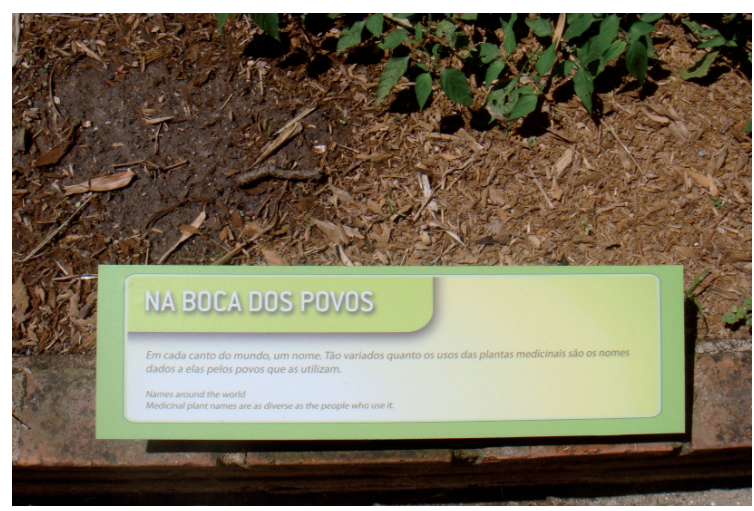

Foto 3: sub-tema Ciência \& Novas Descobertas exemplo de placa informativa

Adotou-se como critério de ordenamento de outros vinte canteiros a classificação taxonométrica, ou seja, o agrupamento das espécies segundo a sua aplicação nos sistemas do corpo humano, recorrendo à literatura especializada e publicações de dados da Etnobotânica. As placas de identificação das espécies deste conjunto cotem os seguintes itens: nome popular, científico, parte usada, sistemas do corpo onde atuam, indicação de uso popular, científico e restrição de uso. Embora consciente da imprecisão do nome popular sua escolha para iniciar a placa deve-se ao fato deste, ser de maior domínio, portanto mais próximo da vivência do cotidiano. Recorreu-se ao uso de dois pictogramas: uma garrafada ${ }^{8}$ e o microscópio foi um recurso usado para ressaltar as diferentes indicações terapêuticas ou apontar o referendo da ciência à informação popular. Os dois níveis de saber estão dispostos lado a lado sem hierarquização de valores.

Foi criada uma nova área denominada "Zona de Troca" que aborda a aproximação do oriente e ocidente e a descoberta do Novo Continente propiciando a influência mútua entre povos e o agir terapêutico.

Por fim, num espaço coberto de aproximadamente de $120 \mathrm{~m}^{2}$ foram usando uma sequência de amplos painéis "Saberes e Olhares diversos" que abordam aspectos das diferentes medicinas tradicionais e complementares.

8 Preparação popular que utiliza vinho ou cachaça para fazer "remédio" a partir de fragmentos de vegetais. 


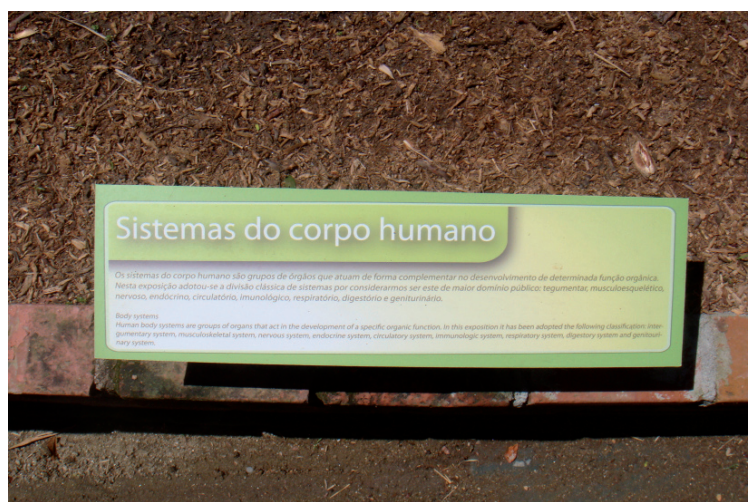

Foto 4 - Placa de introdução do tema corpo humano

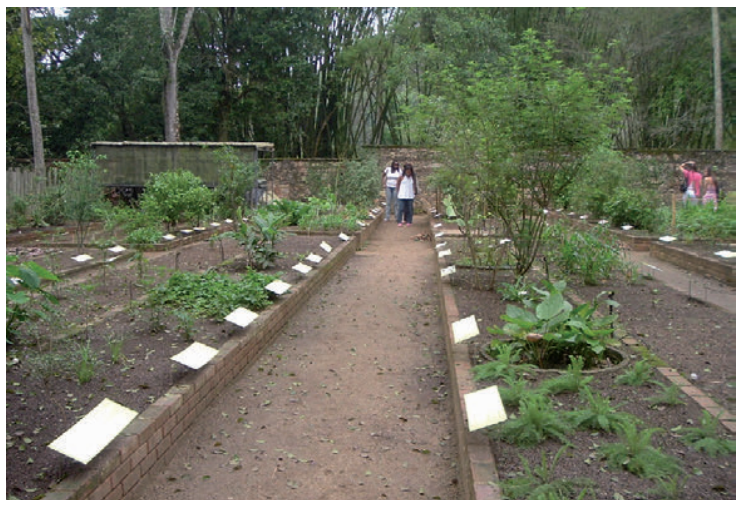

Foto 5 - visão de canteiro do Sistema do Corpo Humano

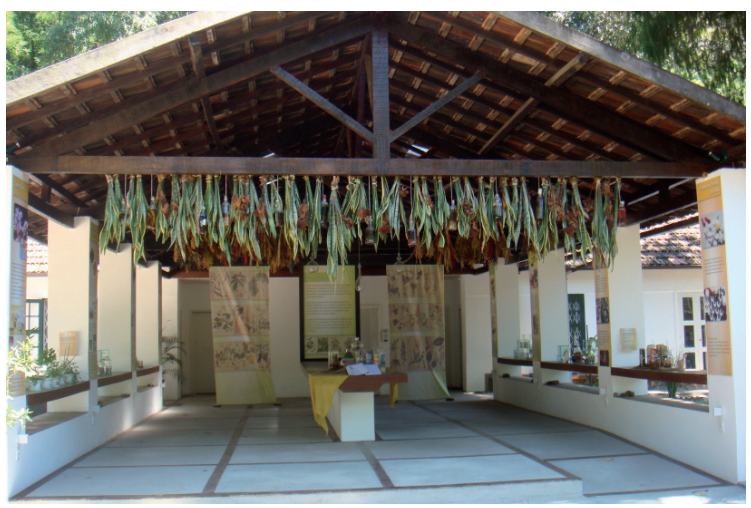

Foto 6 - Espaço expositivo saberes e Olhares Diversos 


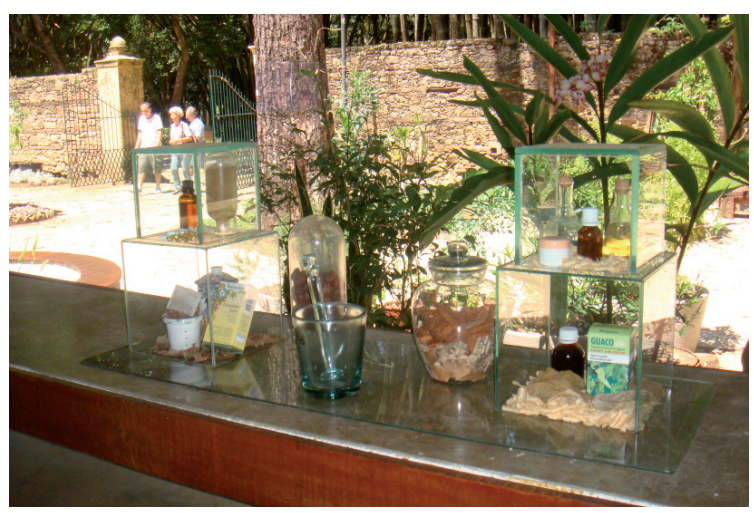

Foto 7 - Matéria prima e preparações

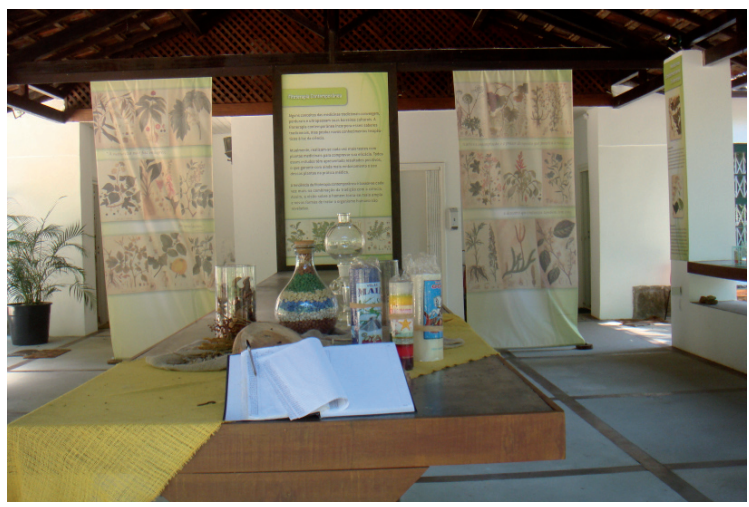

Foto 8

Do lado opostos num outro conjunto "Saber fazer" foram abordados as preparações extemporâneas ${ }^{9}$ e as diferentes preparações farmacêuticas. No último painel o visitante é convidado a refletir sobre a questão preservar para que?

Ainda neste espaço objetos relacionados aos painéis complementam a exposição.

Esta proposta privilegiou a linguagem visual e textual sem negligenciar a precisão do conteúdo. A abordagem usada permite o uso da coleção como espaço de aula, de aprendizado, de significados, reencontro de lembranças e emoções.

9 Preparações caseiras para consumo rápido. 


\section{Referencias bibliográficas}

DONELLY, Gerard T.; FELDMAN, William R. Como definir uma política de coleção de plantas. [s.l.]: [s.n.], [s.d.]. 4 p. Documento apresentado para o Comitê de Coleções de Plantas AABGA.

NORMAS internacionais de conservação para jardins botânicos. 2. ed. Rio de Janeiro, Rede Brasileira de Jardins Botânicos, 2004. 109 p.

DIEGUES, Antonio Carlos; ARRUDA, Rinaldo, S. V. Saberes tradicionais e biodiversidade no Brasil. Brasília: Ministério do Meio Ambiente, 2001. (Biodiversidade; 4).

ELLIS, David W. Diferentes abordagens para organização e funcionamento de centros de ciência. In: SEMINÁRIO INTERNACIONAL DE IMPLANTAÇÃO DE CENTROS E MUSEUS DE CIÊNCIA,1,2002. Rio de Janeiro: UFRJ, 2002. p.19 a 25.

HEYWOOD, V. H. Estratégia dos jardins botânicos para a conservação. Rio de Janeiro: Jardim Botânico do Rio de Janeiro, 1990.

HONIG, Maryke. Como dar vida ao seu jardim!: Interpretação ambiental em jardins botânicos. Tradução Maria Teresa Bernardes. Rio de Janeiro: RBJB, JBRJ, BGCI, 2005.92 p. il.

LEADLAY, Etelka; GREENE, Jane (Ed.). Manual técnico Darwin para jardins botânicos. Rio de Janeiro: Instituto de Pesquisas Jardim Botânico do Rio de Janeiro, 1999. $154 \mathrm{p}$. 
9.

\section{"Transacciones, intercambios y circulación de objetos en el Museo Histórico y Colonial de la provincia de Buenos Aires (Argentina) durante la década de 1920 y 1930". ${ }^{*}$}

Dra. María Elida Blasco ${ }^{2}$

Hace ya varios años la historiografía viene señalando la amplitud y complejidad del dispositivo de circulación de objetos como aspecto constitutivo y central del proceso de apertura y funcionamiento de los museos orientados a la Historia Natural, la Antropología, la Etnografía y la Arqueología, una movilidad cimentada en antiguas experiencias moldeadas por las prácticas de los coleccionistas del siglo XIX (Farro, 2009; Lopes, 1997; Pegoraro, 2009; Podgorny y Lopes, 2008; Podgorny, 2000 y 2010; Pupio, 2005). Retomando esta perspectiva, las páginas que siguen exploran las prácticas sobre las cuales se sustentó esta circulación en un museo argentino especializado en el campo de la historia: se trata del Museo Histórico y Colonial de la Provincia de Buenos Aires instalado en la ciudad de Luján ${ }^{3}$. Según el decreto fundacional dictado el 31 de diciembre de 1917 por el Interventor Provincial, la intención era constituir un museo que evocara "la tradición hispana y colonial de la nación y la provincia", para lo cual se solicitó la restauración de la planta edilicia del antiguo Cabildo de Luján para que funcionara como sede. El

1 Este artículo forma parte de mi investigación doctoral sobre el Museo Histórico y Colonial de la Provincia de Buenos Aires. La tesis fue dirigida por la Dra. Irina Podgorny y defendida en marzo del año 2010 en la Facultad de Filosofía y Letras de la Universidad de Buenos Aires.

2 Neuquén $13067^{\circ}$ B (CP 1405) Ciudad Autónoma de Buenos Aires, Argentina. E-mail: eliblasco@yahoo.com.ar

3 En 1962, en homenaje al historiador y publicista que lo organizó y lo dirigió desde 1923, fue bautizado como Complejo Museográfico "Enrique Udaondo", nombre con que se lo conoce en la actualidad. 
museo abrió sus puertas el 12 de octubre de 1923 - seis años después de emitido el decreto- bajo la dirección del historiador y publicista Enrique Udaondo (Blasco, 2010).

Al momento de su inauguración contaba con un cuerpo principal constituido por "el Cabildo" restaurado y un segundo cuerpo anexo cuya fachada era la denominada Casa del Virrey, la antigua casa de la Real Renta de Tabacos en tiempos de la Colonia que en 1806 había sido habitada por el Virrey Marqués de Sobremonte. Esos edificios albergaban seis salas de exhibición: en la planta alta la Sala del Cabildo contigua al despacho del director, el archivo institucional y la biblioteca. En la planta baja, la Sala de Rosas, la de "las Invasiones y los prisioneros", la Sala Colonial y la Sala de la Independencia. En la "Casa del Virrey" mientras tanto, se alojaba la Sala Dr. Muñiz ya que el sabio la había ocupado entre 1830 y 1845 . A estas habitaciones se agregaban en la planta baja dos patios descubiertos adornados con árboles añejos, enredaderas, cañones, vasijas y tallas "jesuíticas".

La gran cantidad de objetos donados en los meses previos a su apertura permitieron armar la Sala de Rosas y la del Dr. Muñiz, pero también vinieron a romper con el criterio colonial: la primera guardaba piezas de mediados del siglo XIX y la segunda de los años siguientes, el período de la Organización Nacional, la Guerra del Paraguay y la llamada "época contemporánea". Estos mismos criterios de acrecentamiento de colecciones y formación de nuevos espacios expositivos continuaron en años posteriores e hicieron que el "museo colonial" inaugurara salas de muy variada índole: en 1924 por ejemplo, se incorporaba la "Luján" reuniendo "recuerdos locales"; en 1925, la Sección de Transportes con "vehículos históricos y antiguos"; otra reunía las colecciones del fallecido Clemente Onelli, del General José María Paz y del Gaucho. En 1926 se formó la Sala del Indio, en 1928 el lugar que reconstruía el cuarto de trabajo del escritor Ricardo Güiraldes y así sucesivamente.

El objetivo general de este trabajo es dar cuenta del entramado de prácticas y relaciones sociales puestas en funcionamiento a través de los objetos que ingresaban al museo y permitían la formación de nuevos espacios de exhibición. Mediante documentación inédita conservada en el archivo institucional y el archivo particular del director, en primer lugar, nos referimos a las transacciones e intercambios entre coleccionistas, proveedores informales, historiadores, amigos, allegados y casas comerciales. Finalmente, a la circulación de objetos entre instituciones y la competencias de los directores por "atesorar" o "trasladar" piezas en beneficio de "su" institución. 


\section{Transacciones e intercambios.}

Los circuitos de circulación de objetos comenzaron a accionarse cuando el Gobernador de la Provincia de Buenos Aires comunicó a Udaondo su decisión de nombrarlo al frente del museo. El decreto de designación llevaba fecha del 2 de junio de 1923 y con el aval en su poder, el flamante director acudió a casas de antigüedades y librerías para realizar las primeras adquisiciones ${ }^{4}$. Pero además pidió colaboración a sus allegados vinculados a las reparticiones públicas. De esta manera, un día después de su nombramiento recibía una de las primeras colecciones cedidas por el Director General de Arsenales de Guerra: unos cuantos fusiles, granadas y metrallas que aseveraba, era antiguas ${ }^{5}$. El 10 de agosto de 1923 también su amigo Manuel Obarrio le escribía consiguiendo proyectiles: "Te estoy preparando unas cuantas cosas para tu museo. Ya pedí el permiso correspondiente para mandarte la bala de Barragán". Desde 1911 y hasta 1925 el Fuerte Barragán funcionó como Escuela de Aeronavegación y Aviación de la Armada y en sus inmediaciones se habían construido pistas de aterrizajes y hangares que obligaron a hacer excavaciones y modificaciones en los terrenos. No es de extrañar que Obarrio utilizara sus contactos con la fuerza para recolectar piezas para un museo ya favorecido por el Director de Arsenales de Guerra. Mientras tanto, Jacinto Gramajo intentaba otras gestiones. El 19 de septiembre se lamentaba por no poder aportar datos sobre un reloj solar: "imagino lo que podrá interesarle el conseguirlo para el museo" comentaba antes de darle detalles sobre "unos Capiteles de la portada del templo de los Jesuitas en Apóstoles-Misiones"6.

Además, para propiciar la participación popular y sumar colaboradores en los meses previos a la inauguración, Udaondo invitó a los vecinos de Luján a entregar todo aquello que consideraran de mérito artístico o histórico, y tras el pedido las inmediaciones del museo quedaron abarrotadas de curiosidades ${ }^{7}$. Algunas de ellas eran apetecidas

4 Decreto de designación, Registro Oficial de la Provincia de Buenos Aires, enero-junio 1923, Impresiones Oficiales, La Plata, 1926, pp. 594. Boletas a su nombre y correspondencia privada, $\mathrm{f}$. 22-24, caja 91, Fondo Udaondo Archivo de la Academia Nacional de la Historia (en adelante FU. AANH)

5 Carta del Ministerio de Guerra al director del Museo de Luján, 3/6/1923, caja 47, f. 3, FU. AANH.

6 Acta de donaciones, Sala Invasiones Inglesas, f. 15, Archivo del Complejo Museográfico "Enrique Udaondo" (en adelante ACMEU); Carta de Gramajo a Udaondo, Caja 47, f. 4, FU. AANH.

7 Solicitud publicada en La Época, 9 de octubre de 1923. No nos ocuparemos aquí de las donaciones particulares pero podemos afirmar que ellas constituyeron el mecanismo principal de acopio de piezas y acrecentamiento de colecciones. Al respecto ver Blasco, 2010. 
por coleccionistas aficionados e incluso luego de la inauguración del Museo fueron "obsequiadas" por el director para que volvieran a circular por manos privadas 8 .

Otro mecanismo de acopio de piezas fue la compra a casas comerciales. Con este objetivo el 10 de julio de 1924 Muzio Scacciati ofrecía a Udaondo mercadería que saldría a remate:

"Para el día 15 del corriente la firma Guerrico y Villanueva rematará el saldo de las existencia de mi casa de antigüedades pues piña (...) el día 29 pienso dejar libre el local y trasladarme a Europa. Hai piesas (sic) que da lástima verdaderamente abandonarlas por cualquier oferta y que vayan a pasar a manos a lo mejor de personas que tampoco saben apreciarlas. Así que a pesar de no tener ya de mi parte ninguna pretensión de precio, ni las que estén sumamente relacionadas con mi propio costo, pues estoy dispuesto a perder todo lo que sea necesario, me gustaría poner lo mejor en manos y lugares adonde puedan ser debidamente apreciadas" ${ }^{9}$

El comerciante no lo estaba invitando al remate sino que le ofrecía la posibilidad de obtener las piezas con seguridad y sin invertir grandes sumas de dinero:

"El echo (sic) es poder trabar con usted particularmente alguna pieza buena para el museo, sin que nadie sepa en cuanto se a (sic) vendido, unicamente que sea separado del remate para el museo, satisface mi amor propio y lo prefiero aún a un precio mayor que pudiera resultar en remate y me parece que Ud también debería preferirlo. Por qué no se toma la molestia de hacerme una visita? Le harán negocios aun que usted no quiera porque la ocasión no se repite".

El director adquirió gran variedad de objetos pagados de su propio peculio, por ejemplo "un bastón del Virrey Sobremonte" comprado en

8 Ello sucedió con una "talla del apóstol", una "hermosa cabeza de terracota de la imagen de la Santísima Virgen de los Dolores", un "retrato del general Lavalle" y un "antiguo pergamino" que Udaondo remitió al coleccionista Pedro Núñez Acuña en 1925. Correspondencia privada, caja 47, f. 5 y 12, FU. AANH. Carta de Acuña, 9/6/1925, documentación sin foliar, ACMEU.

9 Caja 47, f. 16, FU. AANH. 
el remate de la casa Naón y Cia en junio de $1929^{10}$. Antes de la compra había recibido el informe de autenticidad emitido por su anterior propietario, el hijo de Estanislao S. Zeballos, quien custodiaba la biblioteca de su padre pero comenzaba a desprenderse de otros objetos que podían resultar más redituables. Recordemos que Zeballos padre había muerto en 1923 dejando un fructífero legado en las vitrinas de los museos argentinos: había colaborado en la formación de las colecciones de cráneos indígenas del Museo Público y del Museo de la Plata (Podgorny, 2010; Farro, 2009) y entregado variedad de restos humanos al Museo Histórico Nacional (Carman, 2010). Pero su hijo optaba por transformar la herencia restante (por ejemplo, el bastón de Sobremonte) en algo más provechoso. En el documento enviado a Udaondo certificando la autenticidad, declaraba que "la pieza histórica" había sido obsequiada a su padre por Julio A. Roca adjuntada a una carta sobre el origen del bastón. Pero este documento "debe de hallarse entre los papeles del archivo de mi señor padre", mencionaba; y prometía enviárselo ni bien lo encontrara ${ }^{11}$. El aspecto biográfico del bastón era esencial para determinar su valor ya que la verificación sobre la antigua pertenencia al virrey era vital su transformación en "reliquia".

Pero las prácticas comerciales trabadas a partir de los objetos no siempre se sustentaban en la relación directa entre casas comerciantes y compradores: una abigarrada red de intermediarios, pequeños comerciantes, proveedores informales y despachantes de aduana daban entidad e integraban el mercado de circulación de piezas. Conviene destacar los aportes al museo realizados por Carlos H. Roberts, quien el 17 de octubre de 1928 le contaba a Udaondo los tesoros obtenidos durante su último viaje:

\begin{abstract}
"seguí con mi chifladura de coleccionar recuerdos de las invasiones inglesas. Entre otras cosas traté de conseguir un retrato de Beresford y en esto tuve muy buena suerte pués, aunque me dio mucho trabajo hallé nada menos que cuatro, los que me permito enviarle para el Museo de Luján. Ninguno de éstos he visto en Buenos Ayres, y los que hay en el Museo Histórico son grabados de ningún valor" ${ }^{12}$.
\end{abstract}

10 Boleta a nombre de Udaondo emitida por la casa comercial, actas de donaciones de la Sala Invasiones Inglesas, f. 24, ACMEU

11 Carta de Zeballos a Udaondo, 1/6/1929, f. 25, Actas de donaciones Sala Invasiones Inglesas, ACMEU.

12 Acta de donación de Carlos H. Roberts, f. 223-224, ACMEU. 
A continuación le mencionaba las "cuatro veces" que Beresford "se hizo retratar" y que coincidía con las evidencias conseguidas: según Roberts, la primera vez había sido en 1805 y él acababa de comprar los tres retratos existentes en todo Londres: "uno para usted, uno que le daré al Museo Histórico y uno para mí". La segunda vez había sido en 1814 y había "conseguido dos" de ellos; la tercera (de la cual no describía fecha precisa) le enviaba una copia fotográfica. Finalmente, del último retrato que según él era de 1850, cuando Beresford era "ya muy viejo", había conseguido un único ejemplar "que es el que le mando para que su colección sea completa" finalizaba.

Como vemos las redes locales de circulación de objetos se imbricaban a su vez en el mercado internacional de compra y venta de mercancías; y en la Argentina esa circulación adoptaba convencionalismos y características particulares. El 19 de octubre de 1925 una persona cuyo nombre desconocemos le comunicaba a Udaondo que había conseguido

\begin{abstract}
"una rebaja sobre el precio de un peinetón que se vende en $\$ 1.350$. Es un peinetón muy fino de carey, clarito y muy liviano. La madre de la dueña, una señora muy anciana y distinguida lo llevó en el tiempo de la Independencia y ésta lo llevó en la época de Rosas. Me gustaría que lo viera Ud si no le es muy molesto pasar por mi casa"13.
\end{abstract}

Parece tratarse de un proveedor que gestionaba la obtención de objetos a bajo costo y rastreaba el paradero de las piezas de manera informal, un trabajo similar al que realizaba también Alberto Quiroga: el 29 de marzo de 1928, este le comentaba a Udaondo que

\footnotetext{
"He recibido la medalla y foja de servicios del Coronel de Vergara, de lo que hice entrega a su dueña la Sra. de Vergara. Con respecto a la cama que dicen, fue del General Pueyrredón, he tomado los datos respectivos a fin de que se haga la gestión pertinente. La cama es de un Sr. Cabral, pero está en poder del Teniente Coronel Alberto Linch, cuyo domicilio es Paraguay 2917. El Tte. Linch Pueyrredón, de quien le hablé días pasados, me manifiesta cree fácil que se consiga dicha cama para el Museo de Luján"14.
}

13 Subrayado en el original; caja 47, f. 57, FU. AANH.

14 Carta de Alberto Quiroga a Udaondo, 29/3/1928, f. 90, ibídem. 
Los proveedores informales recolectaban información sobre piezas de interés, rastreaban el paradero, establecían contactos con los propietarios y eventualmente ofrecían dinero a cambio cuando los poseedores rehuían su entrega. Pero el testimonio también advierte el control que las familias ejercían sobre los objetos y por lo tanto también sobre el relato histórico que se producía sobre ellos mediado por la gestión de los comerciantes.

Efectivamente los objetos se acopiaban, cambiaban de manos, se donaban o se compraban apelando a viejas prácticas instituidas por los coleccionistas del siglo XIX. Por otro lado, y respecto al intercambio de piezas por dinero entre numismáticos y coleccionistas, recordemos que eran prácticas aceptadas que Udaondo ahora reactualizaba para enriquecer "su" museo. Detengámonos en un ejemplo significativo. En 1930 Udaondo donó a la institución que dirigía un ejemplar de Arte, vocabulario y tesoro de la lengua guaraní escrito por Ruiz de Monya en 163915. El libro había pertenecido primero a la colección de Andrés Lamas y luego a la de Julio Migoya García quien hacia fines de la década de 1890 actuaba como proveedor e intermediario para la formación de las primeras colecciones del Museo Histórico Nacional. Pero eso no lo inhabilitaba para poner a la venta sus antigüedades: según el relato elevado al director de esa institución, la crisis económica lo había obligado a vender parte de su colección histórica a otros coleccionistas y algunos fósiles "al museo de Burmeister"; pero mantenía aún el resto de sus pertenencias y al no animarse a vendérselas al director del Museo Histórico, le preguntaba por algún coleccionista que quisiera adquirirlos (Carman, 2010). Hacia 1920 Migoya había pasado a colaborar con Udaondo vendiéndole varios libros, entre ellos Arte, vocabulario y tesoro de la lengua guaraní que el director compró para donarlo al museo público que dirigía. La crisis económica de 1890 había quedado atrás pero las prácticas del proveedor-coleccionista-comerciante seguían vigentes. Las diferencias entre el accionar de Migoya y Udaondo eran evidentes. Pero la comparación no parece viable: tal vez las prácticas del primero hubiesen sido otras de haber tenido la posibilidad de dirigir un museo, conseguir un sueldo estatal y un espacio para exhibir sus propias colecciones. Aún así, personajes como estos continuaban colaborando - mediante transacciones comerciales trabadas entre particulares- con el engrandecimiento de las colecciones de los museos públicos.

15 Acta de donaciones de E. Udaondo fechada el 7/1/1930, f. 126, ACMEU 


\section{La circulación de objetos entre las instituciones}

Las instituciones vinculadas a la producción de la historia y al resguardo y exhibición de todo tipo de colecciones también participaron del proceso de circulación de información y de piezas consideradas "relevantes". Pocos días después de la inauguración del Museo de Luján, el director pidió colaboración al Museo de La Plata para "fomentar la obra cultural y patriótica": el 23 de octubre de 1923 solicitaba ceder en depósito los objetos duplicados o "que no encuadren dentro de la especialidad" del museo. Pero además, formalizando gestiones previas trabadas con particulares, especificaba algunas de las piezas que podrían ser cedidas: entre ellas una imagen de San José tallada en piedra en las Misiones Jesuíticas, algunos bustos en yeso "de personalidades argentinas" y telas antiguas con motivos religiosos. El pedido fue concedido y el 16 de diciembre Udaondo solicitaba al secretario del Museo de la Plata que tal lo acordado hiciera entrega al portador de la nota, la talla en piedra, una pila, un arco de hierro y "unos pequeños cañoncitos"16.

Sin embargo, la formalización del pedido de piezas se realizaba luego de haberlo gestionado de manera informal ante las personas que hacían de nexo entre ambas instituciones, por ejemplo Victoria Aguirre Anchorena o los hermanos Benjamín y Gustavo Muñiz Barreto. El 15 de diciembre de 1925 por ejemplo, Udaondo informaba al director Luis María Torre que por intermedio de la primera había recibido el ofrecimiento de "dos imágenes de piedra de las misiones jesuíticas" que se hallaban en La Plata y en gesto de agradecimiento por la cesión que consideraba asegurada, hacía mención a los lazos de reciprocidad futura que uniría a los dos directores ${ }^{17}$. En efecto, es altamente probable que las dos imágenes de piedra de las misiones que se ofrecían ahora, correspondieran a la misma colección de objetos solicitados por Udaondo en 1923 alertado por la misma Victoria Aguirre de que estaban en La Plata. También la familia Muñiz Barreto actuaba como nexo comunicante: mientras Benjamín colaboraba asiduamente con el museo dirigido por Torres, Gustavo lo hacía con Udaondo utilizando los talleres de taxidermia, los trabajadores y la experiencia acumulada en La Plata para embalsamar

16 Carta de Udaondo a Torre, 23/10/1923 y 30/1/ 1924; carpetas de correspondencia año 1923, Archivo del Instituto del Museo de la Plata (en adelante AMLP), c. $n^{\circ} 36$, s/f. Nota de Udaondo al Secretario del Museo, 16/12/1923.

17 Correspondencia interna y externa (s/t), 1920-1926, c. n²2, f. 188; AMLP. 
alguno de los "caballos criollos" que en 1927 donaría a Luján ${ }^{18}$ y que luego Udaondo expondría en la sala del gaucho y en el sector dedicado al "rancho criollo". También Victoria Aguirre y Muñiz Barreto aportaban colecciones al Museo Etnográfico de Buenos Aires; y mientras el director del Museo de la Plata enviaba piezas a Luján, también lo hacía el director del Etnográfico quien en 1925 enriqueció el Museo Colonial e Histórico donando una colección de diez piezas pulidas (Pegoraro, 2009).

Pero el ámbito donde coleccionistas e historiadores exhibían, manipulaban y ponían en circulación objetos, libros y documentos codiciados era la Junta de Historia y Numismática Americana. En julio de 1924 por ejemplo, uno de sus miembros agradecía a Udaondo la donación de un fusil y un mes después se disculpaba por no haberle enviado "ni los papeles, ni las cartas, ni el medallón" prometido. Y otro de ello agradecía el envío de una reproducción fotográfica de su antepasado y dos postales del Museo de Luján ${ }^{19}$. Los obsequios eran retribuidos con otros bienes que en algunas ocasiones eran objeto de crítica por parte de otras instituciones. Una imputación de este tipo pareció surgir en 1926 cuando las autoridades del Museo Histórico Nacional del Uruguay reclamaron a José Juan Biedma "por una colección de proyectiles del sitio de esa ciudad enviada al Museo de Luján con olvido de los Museos Uruguayos"20. Además de miembro de la Junta y amigo de Udaondo, Biedma era un gran coleccionista y ex director del Archivo General de la Nación, por lo tanto proveía al director de Luján de toda clase de cosas que revistieran carácter de "históricas". En este caso, Biedma contaba a su amigo que los autores del reclamo estaban "furiosos". Pero además le preguntaba: "¿de donde sacan eso? ¿Cuándo le he hecho yo tan precioso regalo? ¿Acaso una bomba es susceptible de transformarse en colección de proyectiles? Así suelen escribir historia". Biedma rechazaba la acusación pero revelaba que efectivamente una bomba del sitio de Montevideo había sido enviada al Museo de Luján donde probablemente habría pasado a engrosar una "colección" de proyectiles no "uruguayos" sino "argentinos".

Pero conviene detenerse en un episodio singular inherente a la cultura de la transacción, pero ilustrativo también del control de los empleados y funcionarios públicos sobre los objetos que debían resguardar. El 18 de marzo de 1927 Vicente Livacich escribía a Udaondo

18 Telegrama de Benjamín Muñiz Barreto a Torres, 25/1/1927; carta de Gustavo Muñiz Barreto al secretario del Museo de La Plata, 1/7/ 1927; Cartas interior, 1926-1927, AMLP

19 Carta de Amadeo a Udaondo, Caja 38, f. 35 y 36, FU. AANH. Tarjeta de Marcó del Pont a Udaondo, ACMEU.

20 Subrayado en el original. Carta de Biedma a Udaondo, 15/8/ 1926; caja 38, f. 59, FU. AANH. 
anunciándole la entrega del "histórico chambergo" que había usado Bartolomé Mitre y que "le fue entregado a mi hermano Serafín Livacich en el año 1901 cuando era secretario y bibliotecario de ese personaje"21. También le enviaba libros y manuscritos pertenecientes a su fallecido hermano. Según el acta de donación del 22 de marzo, las piezas enviadas eran más que valiosas ya que incluian gran cantidad de libros de Mitre, impresos, documentos, manuscritos autografiados y fotografías. Cada objeto había sido inventariado por Udaondo pero muchos aparecían marcados con una cruz y al final del acta, se aclaraba:

"Los libros marcados así: X, fueron reclamados y devueltos al Museo Mitre, pues fueron sustraídos de esa biblioteca y Museo".

Habían sido sustraídos por el bibliotecario Serafín. A su muerte había llegado a manos de su hermano Vicente y este ahora los donaba al Museo. Pero las estrechas vinculaciones entre Udaondo y los historiadores que frecuentaban el Museo Mitre, forzaron para que los objetos volvieran a su antiguo lugar de procedencia.

\section{Conclusión: "la epidemia histórica".}

Los chistes de la prensa reflejan con fidelidad la popularidad de las transacciones que incluían la compra, la venta y el intercambio de objetos para formar las colecciones del Museo Histórico y Colonial de la Provincia de Buenos Aires. El 25 de septiembre de 1929, por ejemplo, La Razón publicaba una historieta en donde el personaje Julián de Monte Pío - un porteño avivado y tramposo con pinta de comerciante- primero pedía y luego robaba un viejo animal "destinado para el Museo Histórico de Luján". Y el 4 de junio de 1930 otro irónico cronista ahora de El Diario definía el fervor de los "filántropos donantes" como una verdadera "epidemia histórica" que convendría frenar a fin de no convertir el museo en una "sucursal de El Rastro" madrileño o directamente obligar al gobierno a entregar "enormes latifundios" para albergarlo. Quizá la presencia de estos temas en la prensa esté mostrando - de una manera más sutil que la que ofrecen los documentos pero igual de aleccionadora- que el estudio de los museos históricos y sus colecciones no pueden desvincularse de las redes de circulación de objetos.

21 Carta de Vicente Livacich a Udaondo fechada en 1927, Actas de donaciones Sala Prisioneros, ACMEU. 
Pero también advierte sobre la necesidad de revisar el concepto de "objeto histórico" ya que parece tratarse de una construcción posterior realizada por los historiadores y los directores de museos. Y quizás lo más importante, demuestra que incluso algunos cronistas de la época ironizaban sobre ello: quien en 1930 alertaba sobre la "epidemia histórica" mencionaba también la costumbre argentina de desprenderse de los trastos "históricos" que estorbaban en los hogares patricios y se amontonaban en los desvanes de los caserones coloniales...Podría pensarse que el entrecomillado de la palabra nos pertenece; pero no: expresa la mirada de un cronista hábil en el manejo de la elegancia y la ironía. 


\section{Bibliografía}

- Blasco, María Elida, Un museo para la colonia. El Museo Histórico y Colonial de Luján (1918-1930), Prohistoria, 2010, (en prensa)

- Carman, Carolina, "Redes sociales, Estado y Colecciones en la fundación del Museo Histórico Nacional (1889-1897)", Tesis de Licenciatura en Historia, Facultad de Filosofía y Letras de la Universidad de Buenos Aires, 2010 (inédita).

- Farro, Máximo, La formación del Museo de La Plata. Coleccionistas, comerciantes, estudiosos y naturalistas viajeros a fines del siglo XIX, Rosario, Prohistoria, 2009.

- Lopes, Margaret, O Brasil descobre a pesquisa científica. Os Museus e as ciências naturais no século XIX, São Paulo, Hucitec, 1997.

- Pegoraro, Andrea, "Las colecciones del Museo Etnográfico de la Universidad de Buenos Aires: un episodio en la historia del americanismo en la Argentina, 1890-1927", Tesis de Doctorado, Facultad de Filosofía y Letras de la Universidad de Buenos Aires, 2009 (inédita)

- Podgorny, Irina, El argentino despertar de las faunas y de las gentes prehistóricas. Coleccionistas, museos y estudiosos en la Argentina entre 1880 y 1910, Bs. As., Eudeba/Libros del Rojas, 2000.

El sendero del tiempo y de las causas accidentales. Los espacios de la antigüedad del hombre en el Plata, 1850-1910, Rosario, Prohistoria, 2010

- Podgorny, Irina y Lopes, Margaret, El desierto en una vitrina. Museos e historia natural en la Argentina, 1810-1890, México, Limusa, 2008.

- Pupio, Alejandra, "Coleccionistas de objetos históricos, arqueológicos y de ciencias naturales en museos municipales de la provincia de Buenos Aires en la década de 1950" en História, Ciências, Saúde -Manguinhos, v. 12 (suplemento), 2005, pp. 205-229. 
10.

\section{Museus disciplinares e museus temáticos a busca por novos caminhos}

Luisa Maria Gomes de Mattos Rocha ${ }^{1}$

A musealização de um campo disciplinar do conhecimento envolve os processos de formação de coleção, de pesquisa, de exposição e de uma rede científica de intercâmbio, que subsidiam o discurso museológico e atuam sob o prisma de permanência e transmissão. Esses mesmos processos ocorrem na musealização de um campo temático, ainda que cada um guarde especificidades próprias decorrentes das relações forjadas historicamente entre ciência, estado e sociedade.

Mesmo incorrendo no risco de ter como parte do objeto de estudo fatos contemporâneos, propomos analisar o processo de formação e a matriz conceitual de dois projetos museológicos concebidos em diferentes momentos no Jardim Botânico do Rio de Janeiro: o Museu Botânico, proposto em 1890, e o Museu do Meio Ambiente, projetado em 2008.

Apesar dos diferentes contextos históricos paradigmáticos, a reflexão sobre as matrizes desses museus possibilitará identificar como a sua construção serviu para a institucionalização tanto das ciências no país a partir de um modelo civilizatório europeu quanto da dimensão social do mundo de vida, onde os temas se apresentam na forma de situaçõesproblemas imbricadas em questões de cunho cognitivo, expressivo e moral. Em ambos os casos, a valorização da idéia de uma nação que tem sua identidade constituída pela diversidade natural surge como pano de fundo, mas que se diferencia em particular no tratamento das questões socioculturais, inicialmente consideradas como algo a ser apa-

1 Museu do Meio Ambiente / JBRJ.

E-mail: luisa@jbrj.gov.br 
gado e posteriormente como algo a ser assumido e trabalhado sob a forma representacional e argumentativa.

Nesta reflexão não se trata de buscar modelos ou linhas evolutivas de tipologias de museu, mas de compreendê-los nas suas características singulares e no "lugar" institucional que ocupam a partir de algumas de suas dimensões museológicas como a coleção, a pesquisa, a exposição e o público.

\section{O Projeto do Museu Botânico de 1890}

"Estudo da Botânica e em particular da flora brazileira" (BRASIL, 1890, p.1408)

Em 23 de junho de 1890, o então diretor do Jardim Botânico do Rio de Janeiro, João Barbosa Rodrigues, apresentou por decreto uma nova estrutura regimental para a instituição que refletia o momento histórico e político da consolidação das ciências no país, com a delimitação das fronteiras e aplicações de cada área do conhecimento e suas especializações.

Consubstanciado na missão de estudar a Botânica, Barbosa Rodrigues buscava definir o Jardim como um espaço especializado da Ciência Botânica e, para tal, além de apoiar-se no processo de investigação, criou o Museu Botânico, que passaria a abrigar às coleções científicas e as exposições, essas voltadas a vulgarização do conhecimento científico.

Num primeiro momento, o processo de musealização desta especialidade da ciência ancorava-se na formação de coleções para um público especialista que buscava exemplares para pesquisa e estudo comparativo. No enfoque da permanência, o Museu Botânico teria a função de abrigar um herbário a ser formado das "plantas cultivadas no parque" e um da "flora geral", além de uma coleção amostras de "madeiras de lei e todos os productos vegetaes". Todos devidamente descritos, identificados e classificados como exigiam os parâmetros científicos.

Num segundo momento, o Museu Botânico se direcionou para a apresentação não exaustiva das coleções, contemplando o caráter educativo e didático necessário ao processo de transmissão do saber para o público "amador". 
Uma parte do caminho para galgar um "lugar" no "mundo civilizado"2 já havia sido percorrida, com a formação de coleções botânicas, que representassem a riqueza da flora do Brasil, e a promoção da "instrução pública" baseada em estimular o espírito científico a partir da observação, estudo e comparação. $O$ incremento de relações sociais e acadêmicas com instituições nacionais e internacionais, e a própria criação do Museu Botânico constituíam parte do processo de adaptação e consolidação de um "lugar" epistêmico, institucional e social para a Ciência Botânica.

Ao implantar uma determinada visão de ciência, educação e público no museu, Barbosa Rodrigues assume algumas posições no panorama das discussões nacionais. Defendendo a instrução pública como instância pedagógica e formadora, através do arranjo sistemático das coleções e sua classificação científica, o então diretor almeja que o público ilustrado - qualificado como botânicos, estudantes e amadores interessados em estudar, descrever e comparar a flora nacional - aprenda a "ordem da natureza". Nesta visão, o Museu não apenas instruía, mas apresentava a própria "civilização", com vistas a sua finalidade educadora: a promoção do "processo civilizatório".

Assim, o Museu representava um determinado "lugar" social e epistêmico, o dos cientistas e sua ciência, uma vez que é nestes locais que a comunidade científica negocia práticas, decisões e métodos. Nessa linha, as premissas de neutralidade dos procedimentos descritivos da natureza e seu ordenamento segundo critérios lógicos de classificação traziam no bojo de seu processo de musealização a exclusão da representação de outros "lugares sociais" com suas demandas e práticas socioculturais.

Os critérios da ciência ao mesmo tempo em que certificavam a qualidade das coleções, definiam a informação disponibilizada e requalificavam o seu público como interessados no estudo da ciência. 0 "perfeito" alinhamento garantia a apresentação da "verdadeira" estrutura da ciência consolidando e institucionalizando os domínios disciplinares e apagando, se não esmaecendo, a diversidade sociocultural.

A matriz do Museu Botânico pode ser definida como uma abordagem sistemática tanto na representação quanto na organização museológica, na medida em que a museografia evidencia a estrutura da Ciência Botânica e os seus procedimentos taxonômicos na classificação da flora para ser apropriada simbolicamente pelo público. O processo de

2 Como esclarece Neves e Heizer (2004, p.14), "ser civilizado" significava espelhar-se no modelo e nas necessidades dos grande centros, em particular França e Inglaterra. 
musealização termina por dissolver a fronteira entre ciência e natureza pela subordinação da "natureza à ordem sistemática da ciência" (GOMES, 2006, p.108). Configura-se um lugar social, epistêmico e institucional para celebrar uma determinada visão e prática científica, legitimar e profissionalizar o estilo de vida de um segmento da sociedade e projetar no devir a sua musealidade.

Defendendo o levantamento da nossa diversidade vegetal pelos cientistas brasileiros, a epígrafe de Barbosa Rodrigues é um alerta para a necessidade de ancorar institucionalmente a Ciência Botânica, legitimando "a emergência e desdobramento de famílias de questões"3 que possibilitam a agregação paradigmática dos saberes com base nas relações produtivas do fluxo de pesquisa das comunidades e instituições e suas redes de formação e transmissão. Na visão de Gonzalez de Gomez (2003, p.73), as instituições de pesquisa e educação tendem a refletir esta estrutura cognitiva e epistêmica de produção, organizadas e representadas de acordo com áreas e subáreas do conhecimento.

$\mathrm{Na}$ nossa perspectiva, os museus, como "expressões institucionais"4 das ciências com capacidade de congregar os processos de pesquisa, formação e transmissão, têm o potencial de cumprir uma agenda ampla de consolidação de alguns princípios e saberes paradigmáticos. Não resta dúvida que o projeto do Museu Botânico de 1890 vem em busca dessa potencialidade de musealização de uma área disciplinar especializada de conhecimento.

\title{
O projeto do Museu do Meio Ambiente de 2008
}

\begin{abstract}
"sensibilizar a sociedade para a importância da conservação da biodiversidade e da promoção de formas sustentáveis de relação entre a humanidade e o meio ambiente." (ROCHA et al, 2007)
\end{abstract}

Em 18 de novembro de 2008, o presidente do Instituto de Pesquisas Jardim Botânico do Rio de Janeiro5, o ambientalista Liszt Vieira, criou

3 Gonzalez de Gomez (2003, p.73) analisa os três principais eixos de integração e avaliação dos conhecimentos, no Brasil e na América latina: o eixo paradigmático, o eixo corporativo e o eixo territorial.

4 Lopes (1997, p.12)

5 Em 1998, o Jardim Botânico do Rio de Janeiro transformou-se em Instituto de Pesquisas Jardim Botânico do Rio de Janeiro e em 2001, passou a ser uma autarquia federal ligada ao Ministério do Meio Ambiente. 
por decreto regimental o Museu do Meio Ambiente com a atribuição de planejar, promover, coordenar e avaliar a execução das atividades museológicas e museográficas relacionadas às questões ambientais. De um modo similar, o eixo estruturante deste museu também reflete um momento histórico e político de consolidação de agendas nacionais e internacionais, mas agora sobre uma temática transversal que permeia as relações científicas, tecnológicas, produtivas, sociais e culturais.

Ao contrário de institucionalizar estruturas paradigmáticas ou delimitar fronteiras do conhecimento, o Museu do Meio Ambiente se volta para um domínio mais amplo de produção de conhecimento, estruturado a partir de um conjunto de temáticas relacionadas à preservação da vida no planeta ancoradas em "dimensões significativas da vida e do ser social, junto à rede complexa de agentes, relações, atividades, meios e recursos que intervêm em sua realização" (GONZALEZ DE GOMEZ, 2003, p.73).

Ao direcionar a sua missão para a sociedade e propor a discussão de formas sustentáveis de relação entre a humanidade e o meio ambiente, o recém criado Museu desloca os processos comunicacionais museológicos, ancorados anteriormente no mundo objetivo da ciência, para um mundo social comum, no qual todos os envolvidos podem se tornar participantes, ao menos representacional e argumentativamente, defendendo e criticando as visões e posições apresentadas.

O objetivo do Museu de se constituir em um fórum permanente de discussão das questões ambientais define alguns alinhamentos conceituais de sua matriz. No âmbito educacional, o Museu se direciona para os processos de aprendizagem pautados nas ações de formação científica, social e cultural, a partir de propostas críticas, criativas e investigativas que associem a reflexão do mundo ao questionamento e a sua transformação.

No âmbito epistêmico, a perspectiva ambiental reconfigura o enfoque interdisciplinar, não mais pautado pela delimitação de um objeto de estudo, mas pela complexidade de articulações de novas estruturas conceituais que dêem conta de "problemas" que se mostram transversais a ciência, ao estado e a sociedade.

Por isso mesmo, a complexidade e transversalidade da temática do museu demanda ampliar o campo de discussão contemplando aspectos cognitivos, estéticos e morais, em função do caráter plural da formação nos espaços comunicacionais, onde controvérsias e negociações culturais ocorrem entre os diversos públicos. 
No âmbito comunicacional, exibir espacialmente as relações e articulações a respeito de um "problema ambiental" demanda uma nova cartografia de saberes, que a despeito de ter ações impulsionadas pelos princípios paradigmáticos e corporativos, ancora-se em um princípio territorial $^{6}$. Como afirma Gonzalez de Gomez (2003, p.73), nesse tecido semântico-territorial a ciência e a tecnologia têm seus princípios reformulados conforme "famílias de problemas".

Com uma matriz direcionada para a interação social, os espaços comunicativos das exposições tornam-se os articuladores das diferentes visões e "jogos de linguagem" ${ }^{\prime 7}$ acerca das questões emergentes na esfera ambiental, de forma que a compreensão e o conhecimento estejam coordenados socialmente e condicionados e mediados pela experiência histórica. Um "lugar" social de compartilhamento de saberes e práticas socioculturais, historicamente determinadas, reformula a organização e apresentação da informação, agora referenciada situacionalmente, articulando os diferentes atores, discursos e ações evidenciando o contexto, o tempo e o lugar de onde se originaram.

Na nossa perspectiva, o processo de musealização da temática meio ambiente ancora-se na articulação de fluxos de comunicativos gerados a partir de suportes institucionais configurados pelos programas museológicos de caráter educativo, expositivo, acervo e divulgação científica, que objetivam o adensamento da reflexão sobre as questões ambientais. A formação de redes colaborativas de intercâmbio de informação adquire maior relevância e pertinência frente às dinâmicas e provisórias atualizações do conhecimento sobre o Meio Ambiente.

A formação de coleções científicas sobre a biodiversidade brasileira encontra no Instituto de Pesquisa Jardim Botânico o seu "lugar" institucional. Enquanto, os suportes e linguagens audiovisuais, característicos do mundo contemporâneo, encontram no Museu do Meio Ambiente o seu tempo e lugar, espaço para permanência e transmissão por diversas formas, meios e processos.

A dissociação entre os critérios que classificam e organizam o conhecimento desses dois espaços institucionais espelha a separação entre coleção e exposição, iniciada com as teorias sintéticas da ciência, e aqui revivida, na sua radicalidade, com a organização e representação do conhecimento institucional. Contudo, não podemos esquecer que

6 Território: local onde se produz as relações sociais e simbólicas (AUGÉ, 2006, p.107)

7 Wittgenstein (1979, §23, p.18). 
os museus tendem também a refletir na sua organização as concepções de "ciência" e de "natureza" vigentes nas diferentes épocas, em particular, aquelas que assumem o papel hegemônico entre as comunidades. Assim, a emergência e urgência da temática ambiental têm reconfigurado às agendas políticas, científicas, sociais e culturais, pautando tanto as discussões quanto as ações de pesquisa, cada vez mais colaborativas e interdisciplinares.

Ao propor a implantação de um Museu do Meio Ambiente, o Instituto de Pesquisas Jardim Botânico sinaliza, de forma semelhante a 1890, para a importância de assegurar um "lugar" institucional para a temática ambiental, motivo pelo qual propõe a sua musealização. Se em 1890, o botânico Barbosa Rodrigues propõe um Museu Botânico, em 2007, o presidente da instituição, que têm sua vida pautada pelo compromisso com o meio ambiente, cria um Museu do Meio Ambiente. Ambas as ações apontam para a influência das características biográficas de seus dirigentes nos rumos da instituição.

Entretanto, o lugar institucional escolhido - o Museu do Meio Ambiente - não se definiu mais por estruturas cognitivas e epistêmicas, mas por feixes relacionais associados a um tema, que aposta na configuração de um "lugar" social pautado na pluralidade de concepções de mundo e formas de vida como princípio de adensamento de fluxos de comunicação entre ciência, estado e sociedade, estimulado pela participação pública na discussão ambiental.

Defendendo a importância da conservação da biodiversidade e sustentabilidade da relação humanidade e meio ambiente, a epígrafe aponta para a necessidade de transformação de conceitos, valores e procedimentos que embasem uma nova concepção de mundo. Apesar de distantes neste novo caminho a percorrer, a dimensão pragmática permite redefinir as práticas de comunicação museológicas na direção de pressupostos compartilhados a partir dos quais podemos tematizar o mundo e confrontar os nossos valores e normas a luz das expressões culturais do outro. 


\section{Referências bibliográficas}

AUGÉ, MARC. Sobre modernidade: do mundo tecnológico de hoje ao desafio essencial do amanhã. In: MORAES, Denis de (Org). Sociedade mediatizada. Rio de Janeiro: Mauad, 2006. p. 99-118.

BRASIL. Decreto 23 de junho de 1890. Reorganiza o Jardim Botânico. Lex: Decretos do Governo Provisório da República dos Estados Unidos do Brazil, Rio de Janeiro, Imprensa Nacional, 1896.

GOMES, Helder. Missão Botânica - Transnatural: [Catalogo da Exposição]. Coimbra: Universidade de Coimbra, 2006.

GONZALEZ DE GOMEZ, Maria Nélida. As relações entre ciência, Estado e sociedade: um domínio de visibilidade para as questões da informação. Ciência da Informação. Brasília: v.32, n.1, p.60 - 77, 2003.

HEIZER, A. L.; NEVES, M. S. A Ordem é o Progresso. O Brasil de 1870 a 1910. São Paulo: ATUAL Editora, 2004.

LOPES, Maria Margareth. O Brasil descobre a pesquisa cientifica: os museus e as ciências naturais no século XIX. São Paulo: Huitec, 1997, 369 p., p.297.

ROCHA, L. M. G. M.; MACHADO, Carmen; HEIZER, Alda; PADUA, Jose Augusto. Relatório para implantação do Museu do Meio Ambiente. 2007

WITTGENSTEIN, Ludwig. Investigações filosóficas. São Paulo: Abril Cultural, 1979. $222 \mathrm{p}$. 


\section{1.}

\section{Formación de museos y colecciones a fines del siglo XIX en las provincias argentinas de Entre Ríos y Corrientes}

María Núñez Camelino ${ }^{1}$

En este trabajo se pretende examinar el proceso de surgimiento los museos de las provincias argentinas de Entre Ríos y Corrientes y las prácticas asociadas a la conformación de sus colecciones, a fines del siglo XIX.

Este proceso presenta ciertas similitudes. En ambos casos, el surgimiento de estos museos se relaciones con la figura de Pedro Scalabrini, quien a partir del establecimiento de ciertas relaciones sociales con diferentes instituciones de orden nacional y sus gestiones con los diferentes gobiernos de las provincias mencionadas, logrará concretar la creación de ambos museos a través de la donación de sus colecciones personales de objetos de historia natural y posicionándose en ambos casos como director de las dos instituciones.

Una vez logrado el apoyo institucional y político para la creación de estos museos, Scalabrini iniciaba los mecanismos tendientes al incremento de las colecciones. Por una parte, se pueden mencionar sus propias excursiones para la recolección de nuevos materiales, por otro, se recurría a otras estrategias: la publicación de los inventarios de las colecciones en los medios locales (periódicos, diarios y revistas), se anunciaba la donación de nuevos objetos o una nueva colección por parte de algún particular y se establecían redes de comunicación con instituciones escolares del interior de las provincias con el fin de que éstas recolectaran material para los museos de las capitales provinciales.

1 Instituto de Historia- Facultad de Humanidades- Universidad Nacional del Nordeste- Argentina E-mail: mariacncayahoo.com 


\section{Algunos datos biográficos sobre Pedro Scalabrini}

Nacido en Italia en 1848, Scalabrini llegó a la Argentina a los veinte años luego de ser expatriado por razones políticas. En el país tuvo destacada actuación docente, fundó en Buenos Aires la escuela particular Florencio Varela, en Paraná el Colegio Sud América, fue docente del Colegio Paraná en 1868 y formó parte del plantel inicial de docentes de la Escuela Normal de Paraná en 1872, centro de difusión del positivismo comtiano (Bosch, 1993: 212; Martínez Paz, 2001; Petriella y Miatello, 1976). Además allí enseñó historia general, historia natural y castellano (Petriella y Miatello, 1976).

Scalabrini tuvo siempre destacada y activa participación pública: en Paraná fue varias veces presidente de la Sociedad Italiana, reorganizó el Museo Escolar Sarmiento con colecciones de su propiedad, fundó la Asociación Nacional del Profesorado y presidió un Consejo Escolar, entre otras participaciones en instituciones científicas, pedagógicas y literarias. Falleció en Buenos Aires en 1916 (Petriella y Miatello, 1976).

En Corrientes, colaboró con la Revista "La Escuela Positiva" y mantuvo relaciones con uno de los representantes y referentes de esta corriente filosófica es J. Alfredo Ferreira, quien desempeñó diferentes cargos durante las administraciones de Valentín Virasoro y Juan Esteban Martínez (Gabardini, 1995).

\section{El contexto de surgimiento de los museos de Entre Ríos y Corrientes}

Scalabrini consideraba en sus escritos que los museos constituían símbolos del progreso humano y del avance de la ciencia:

"... la fundacion de un museo es considerada en todas partes como el resultado de una elevada cultura intelectual colectiva y como un factor importante de nuevos y rapidos progresos en el conocimiento de los seres, base fundamental y esencial de la ciencia moderna..." (Scalabrini, 1897: 1316)

Mantegari opina que, principalmente desde la segunda mitad del siglo XIX, los museos pasan a constituir instituciones a la vez educativas y de investigación, con una creciente dependencia financiera del Estado y de las políticas gubernamentales. En particular, en el caso de 
los museos de ciencias, ya no se trata de la mera acumulación de objetos, si no de su selección y ordenamiento de acuerdo con una visión científica del mundo, todo ello acompañado de un carácter instructivo que se traducía en la publicación de guías y catálogos (Mantegari, 2000).

Sin embargo, esa situación descripta por Mantegari y aquellos objetivos propuestos por Scalabrini en general no fueron alcanzados. Eduardo A. Holmberg, en un recorrido realizado por varios museos provinciales y regionales del país, deja ver su visión crítica sobre el estado de los mismos, el amontonamiento de las piezas, el descuido edilicio (especialmente cita los casos de los museos de Entre Ríos y Corrientes, los cuales presentan esta situación a pesar de la buena voluntad de las personas a cargo), pero principalmente critica la política que subyace en la creación de estos museos.

"Fundados los museos mas por la necesidad de tener iniciativas y hacer algo muy importante, que por las otras razones, los gobernantes hallaron en su obra un título digno de honrosa mención, como que a nadie puede decirsele, usted ha hecho mal en darnos un museo. Pero ahora, en vista de los resultados obtenidos, yo pregunto, $Y$ ¿qué provecho se ha sacado? ¿Qué ha aprendido el pueblo? iNada! Porque se ha principiado por falsear el carácter que debió dárseles. Sin otros modelos que los museos de Europa; el lujoso de La Plata o el de Buenos Aires, han querido hacer otro tanto, fundando Museos de Historia Natural sistemática, cuando debieron hacerse museos de aplicación" (Holmberg, 1902: 272,273)

De alguna manera, a partir de su actuación docente, su vinculación con entidades científicas e instituciones y personajes políticos, Scalabrini propondrá la creación de los museos de Entre Ríos y de Corrientes, contando para ello con sus propias colecciones como colecciones iniciales y asegurándose siempre el cargo de director de estas instituciones.

Ambrosetti, quien fue su colaborador en el Museo de Entre Ríos, destacó su espíritu altruista como rasgo fundamental de su personalidad, al resaltar la donación de sus colecciones para concretar la creación de los museos de Paraná y de Corrientes (Ambrosetti, 1916: 228). 


\section{El caso de Entre Ríos}

De acuerdo con el relato de Ambrosetti, en una conferencia dictada en diciembre de 1883 en el Instituto Geográfico Argentino sobre la geología del Paraná, Scalabrini propuso crear un museo en Paraná que reemplazara a aquel que había sido fundado en época de Urquiza y que había desaparecido². Para concretar esta idea, ponía a disposición de la nueva institución sus propias colecciones ${ }^{3}$. Contando con el apoyo del gobernador de la provincia de Entre Ríos, el general Racedo, finalmente se firmó su decreto de fundación el 14 de febrero de 1884 (Ambrosetti, 1916: 229)4. En enero de 1886, en su informe dirigido al Ministro de Hacienda y Gobierno Sabá Z. Hernández, Scalabrini solicitaba las designaciones de Toribio Ortiz como jefe de la sección Paleontología y $\mathrm{J}$. Bautista Ambrosetti en la de Zoología (Archivo de Paraná, Carta al Ministro Hernández, 18 de enero de 1886) $)^{5}$. En cuanto a la colección inicial, el gobernador Racedo fue quien, en su discurso del 1으 de mayo de 1886, dio cuenta de las secciones y los objetos respectivos a las mismas:

2 En 1854, el gobierno de la Confederación Argentina radicado en Paraná, había creado un Museo Nacional cuyo director designado fue Alfredo Marbais Du Graty (belga de origen). De la misma manera, en 1852, el gobernador de Corrientes Juan Pujol, le había encargado a Aimé Bonpland un gabinete de historia natural (Podgorny y Lopez, 2008).

3 En la conferencia presentada ante la Sección del Paraná del Instituto Geográfico Argentino, dada el 6 de enero de 1884, Scalabrini describía los restos fósiles recolectados por su persona, muchos de los cuales habían sido estudiados por Ameghino, entre éstos se encontraban roedores, paquidermos, rumiantes, carnívoros y desdentados como gliptodontes, megaterios y otros (Boletín del Instituto Geográfico Argentino, 1884, Tomo V).

4 Ambrosetti relata que "un hecho singular apresuró este acontecimiento. El doctor Desiderio Crespo había descubierto unos restos fósiles de Toxodonte en el arroyo Antoñico, próximo a la ciudad de Paraná. Comunicado el hallazgo al gobernador Racedo, éste dispuso presenciar su extracción, e invitando al profesor Scalabrini, se trasladó con su ministro, doctor Miguel Laurencena y una comitiva de personas, al lugar mencionado" (Ambrosetti, 1916: 230). Con este motivo, Scalabrini publicó un artículo en el diario El Constitucional, elogiando la actitud del gobernador y manifestando su esperanza en el desarrollo de las ciencias naturales en Entre Ríos. Días después se firmó el decreto de creación del museo (Ambrosetti, op. cit.: 230).

5 En la obra biográfica de Cáceres Freyre, se puede consultar el decreto del 28 de abril de 1886 que designa a los colaboradores de Scalabrini: Juan Bautista Ambrosetti como Director de la Sección Zoológica, Toribio Ortiz de la Sección Paleontológica, ambos con una dotación de m\$n 60 mensuales. Además se los designa naturalistas viajeros y se destinan m\$n 25 mensuales para las excursiones científicas (Cáceres Freyre, 1967: 26). 


\begin{tabular}{|c|c|c|}
\hline & Secciones & \\
\hline & Mineralógica & 1500 \\
\hline & Botánica fósil & 200 \\
\hline & Zoófitos fósiles y vivientes & 150 \\
\hline & Insectos vivientes & 4000 \\
\hline & Crustáceos fósiles y vivientes & 140 \\
\hline$\stackrel{\varrho}{\gtrless}$ & Moluscos & 1500 \\
\hline$\frac{a}{\frac{0}{2}}$ & Peces & 1300 \\
\hline & Reptiles & 508 \\
\hline & Aves vivientes & 16 \\
\hline & Mamíferos fósiles y vivientes & 1100 \\
\hline & Antropología & 300 \\
\hline & Numismática & 130 \\
\hline & Teratología & 10 \\
\hline & Total de objetos & 10854 \\
\hline
\end{tabular}

En un primer momento, el museo ocupó algunos salones de la propia casa de Scalabrini hasta que se trasladó a un local propio en 1888, permitiendo esto la ampliación de sus colecciones (Ambrosetti, 1916) ${ }^{6}$.

En ese mismo año, publicó un trabajo sobre el positivismo y con ello renunció a la dirección del museo. Como consecuencia de su renuncia, el museo entró en un estado de vida "anémica" según la opinión de Ambrosetti y se perderá como institución. Holmberg también reflejará la decadencia del museo una vez que figuras como la de Scalabrini y Ambrosetti se hayan alejado de la institución:

"El museo hace una impresión desastrosa, tiene olor de olvido y aspecto de vizcachera. Hay vidrios rotos y han sido reemplazados con papeles de diarios viejos que muestran sus grandes títulos, asomándose por entre los marcos de las ventanas sucias de tierra y de moscas. En una de las salas, la principal, hay un

6 En el informe anual correspondiente al año 1885, presentado el 18 de enero de 1886 se informa sobre el aumento considerable de las colecciones del museo, destacándose el aporte de las colecciones del señor Juan Bautista Ambrosetti, entre las restantes donaciones de otros particulares (Scalabrini, Informe al Ministro de Gobierno, 18/01/1886,AGER). 
avestruz que recibe siempre cortésmente inclinado, como que encima le ha caído todo un pedazo de papel y tela del cieloraso, que ahí estará hasta que el avestruz concluya de caerse ó hasta que alguien se lleve el museo" (Holmberg, 1902: 272)

Probablemente su relación con Ferreira haya contribuido a su alejamiento del museo de Paraná y su designación como fundador y director del nuevo museo en Corrientes.

\section{El Museo de Corrientes}

El 24 de mayo de 1894 los periódicos locales anunciaban la llegada de Scalabrini a la ciudad de Corrientes. Mientras el periódico opositor, El Litoral, sólo dedicaba unas líneas al anuncio, La Libertad repasaba sus antecedentes, destacando especialmente su labor como docente de la filosofía positiva y como fundador del museo de Entre Ríos y resaltando su actividad paleontológica (La Libertad y El Litoral, 24/05/1894, AGPC).

En el número de 1896 de la Escuela Positiva, se publica la resolución del Consejo Superior de Educación por la cual se crea el Museo de Corrientes, además de transcribirse el acta de inauguración que tuvo lugar el día 25 de diciembre de 1894, acto que contó con la asistencia del gobernador Valentín Virasoro y de Alfredo Ferreira. En la mencionada resolución se fundamentaba la creación de esta institución en la necesidad "del progreso científico e industrial de la Pcia."7.

La designación de Scalabrini no dejó de ser aprovechada para generar controversias entre los opositores al gobierno de Virasoro, despertando críticas acerca de las condiciones en que se instalaba el nuevo museo.

"Ya tenemos museo, se han dicho los triunfadores sobre la barbarie, y propusieron al gobierno la adquisición en donacion del que se ha instalado en local especial en esta capital. Como sola condicion se proponía al donante, un señor Scalabrini, como director con un sueldo mensual de 300\$ - que forma una partida anual de 3.600 nacionales.

7 Con el decreto de fundación se designaba como director a Scalabrini se le otorgaban $30 \$ m n$ mensuales, además de presupuesto para un auxiliar, excursiones publicaciones, conservación, un portero y la compra de armarios y mostradores. (Gabardini, 1995: 130). 
Este señor Scalabrinies además profesor en la escuela normal del Paraná, adonde actualmente reside para el cumplimiento de sus deberes de maestro.

No comprendemos un empleado en estas condiciones, y mas que todo no alcanzamos la gratitud en la donacion, alrededor de lo cual se ha hecho tanto ruido de bombo.

Pero tenemos museo, y este hecho nos eleva en condiciones de adelanto para el exterior aunque el erario público se resienta y los bolsillos del profesor Scalabrini se vuelvan repletos.

Vamos adelante." (El Litoral, 14/10/1894, AGPC).

La respuesta del gobierno se hizo pública a través del periódico que apoyaba su gestión, La Libertad, con una nota que llevaba el título de "Calumniadores".

Entre otros términos, se expresaba:

"Parece mentira que en su indigna propaganda llegue el periódico ese a calumniar a un hombre de alta talla moral e intelectual.

... Pensar que el señor Scalabrini, siendo director del museo de esta provincia, ejerce tambien el cargo de profesor de la E. Normal del Paraná, sería considerar mas que vil a un hombre verdaderamente honorable; y pensar que hoy se halla ejerciendo ese cargo en la mencionada escuela, es no tener otra inspiración que la del mal..." (La Libertad, 18/10/1894, AGPC).

Finalmente, el museo fue fundado originalmente con 5725 objetos, fruto de la donación de Scalabrini. Muy poco tiempo después ya contaba con $8859^{8}$.

8 El 23 de diciembre se anunciaba la inauguración del museo y se adelantaba el programa de actividades que se realizaría en esa ocasión, lo que incluía palabras por parte del gobernador Virasoro, un espectáculo musical a cargo de Eneas Verardini y de Italo Mazzanti que incluía la Variaciones del Carnaval de Venecia de Paganini. El 25 de diciembre se produjo la inauguración con gran asistencia de público. (La Libertad, 23 y 27/12/1894, AGPC). 
Ambrosetti cita la concepción de Scalabrini acerca de la importancia del museo:

"La organización actual del establecimiento responde a su triple objeto de escuela popular, exposición permanente y auxiliar didáctico.

En el día ya no se discute la utilidad teórica y práctica de esta institución, considerada indispensable, como es la iglesia, el hospital, la escuela, la biblioteca y el banco" (Ambrosetti, 1916: 236).

\section{Estrategias de conformación y acrecentamiento de las colecciones}

En ambos museos, Scalabrini adoptó una política de difusión de los trabajos y actividades realizadas; en el caso de Entre Ríos, a través de las cartas al gobernador Racedo, que consistían básicamente, en la enumeración y descripción de las colecciones depositadas en el mismo. Muchas de esas colecciones habían sido donadas por el mismo gobernador?.

Los inventarios consultados de los años 1886 se encargan de mencionar quiénes son los donadores de algunas de las colecciones ${ }^{10}$. Algunos de los donadores son colaboradores habituales del museo y donan tipos especiales de materiales y colecciones, entre éstos podemos mencionar a Tomás Mazzanti, Leopoldo Echeverría ${ }^{11}$.

Podgorny explica cómo entre fines del siglo XIX y los inicios del siglo $X X$, se da un proceso de asociación entre dos espacios: el del laboratorio

9 En el Tomo XXII de los Anales de la Sociedad Científica Argentina se publican algunas de estas cartas: en la carta del 31 de agosto de 1886, expone sus observaciones sobre los moluscos fósiles que integraban la colección donada por el gobernador en marzo del mismo año (ASCA, 1886: 173-176). En septiembre continúa con la enumeración de la colección de los radiarios fósiles (Ib.: 176-179). En octubre, se dedica a los vegetales fósiles y vivientes (Ib.: 224-230).

10 En la memoria de 18/01/1886 dirigida al ministro Hernández, Scalabrini menciona las donaciones ya recibidas de Ambrosetti y destaca la protección que ha recibido el museo por parte del gobernador Racedo (Scalabrini, Carta dirigida al Ministro Hernández, 18/01/1886, AGER).

11 En su inventario del 30 de noviembre de 1886 dirigido al director, Ambrosetti destaca dos colaboradores: "Entre ellos debo hacer mención al Sr. Dn. Leopoldo Echevarría a quien se le deben las importantes colecciones del territorio de Misiones.

No debo pasar por alto la generosa donacion del Sr. Dn. Jose Sors (hijo) que ha donado su colección al Museo y sigue siempre coleccionando para él". Además mencionaba la colaboración de naturalistas reconocidos como Berg, Holmberg y Lynch Arribálzaga en la clasificación de las colecciones. (Ambrosetti, Informe al Director Scalabrini, 30/11/1886, AGER). 
del experimento y el campo. Cuando comienza a cuestionarse la evidencia, es decir las colecciones, comienza un proceso de "normalización" de la excavación, especialmente en la arqueología de principios del siglo XX (Podgorny, 2009).

Para la época en que Scalabrini se encuentra en el Museo de Entre Ríos, consideraba de importancia las salidas al campo en busca de materiales que ayudaran a la formación de las colecciones de los museos.

Según relata Ambrosetti, solía decir:

"Créame, joven naturalista, me repetía con tono jovial, que nuestra tarea de vizcachas inteligentes, al pie de las barrancas, tiene tanta o más importancia que la descripción sistemática de las piezas.

Tomemos a pecho nuestra misión y tratemos de hacer todo lo posible antes que se pierda el yacimiento por cualquier causa, dada la movilidad del río o lo inseguro de las barrancas.'

$Y$ con estas ideas fundamentales, durante una larga temporada, se trabajó con ahinco, sin otra mira que el de aumentar las colecciones." (Ambrosetti, 1916: 229)

Ambrosetti y Ortiz durante su etapa como colaboradores del museo realizaron también excursiones entre 1886 y 1889 (Ambrosetti, 1893:7) ${ }^{12}$

Como estrategia para aumentar las colecciones del museo, se acostumbraba publicar en los periódicos locales los nombres de los donadores y así se estimulaba el interés por la institución. Además, especialmente en el caso de Corrientes, se establecían contactos con las escuelas del interior de la provincia las que contribuyeron enviando objetos didácticos elaborados por sus discípulos. De esta manera, la colección general del Museo de Corrientes aumentó a un total de 13.011 piezas (Ambrosetti, 1916).

Tal como lo hiciera en Paraná con las cartas al gobernador Racedo, Scalabrini publicó en la Revista de la Escuela Positiva, diferentes "Cartas científicas", cuyo objetivo era la descripción de las colecciones del Museo de Corrientes ${ }^{13}$.

12 Algunas de estas excursiones fueron mencionadas y descriptas por Ambrosetti en su publicación "Sobre una colección de alfarerías minuanes" (Ambrosetti, 1893b)

13 En números sucesivos, Scalabrini se va dedicando a publicar el inventario de las diferentes colecciones del museo organizadas por secciones y anuncia otras actividades de las que el museo 
La estrategia utilizada por Scalabrini formaba parte de una tendencia según la cual era importante para cualquier museo fomentar el aumento de sus colecciones. Este incremento de las colecciones y la acumulación de piezas constituyeron una de las particularidades de los museos del siglo XIX.

\section{Consideraciones finales}

Este trabajo intentó demostrar cuáles fueron los mecanismos utilizados para el surgimiento de dos museos provinciales en la Argentina de fines del siglo XIX: los museos de Entre Ríos y Corrientes.

Por un lado, una persona, Pedro Scalabrini, quien ya desarrollaba una actividad institucional como profesor en la Escuela Normal de Paraná, pero que además era un reconocido naturalista, emplea las mismas estrategias para alcanzar el apoyo político necesario para lograr la creación de los dos museos ya mencionados y asegurarse el cargo de director de los mismos a través de la donación de sus colecciones particulares.

Una vez establecidos estos museos, se planteaba la necesidad de aumentar las colecciones ya existentes mediante diferentes estrategias:

Por un lado, el trabajo de campo. Con las excursiones y viajes de recolección de material (hemos mencionado los de Scalabrini, Ambrosetti y Ortiz), se incorporaban nuevos materiales.

Por otro, se estimulaba la donación de colecciones u objetos por parte de particulares a través de los informes e inventarios elevados a los funcionarios provinciales correspondientes y a través de las publicaciones en distintos periódicos y revistas locales. Se acostumbraba hacer particular mención de los donantes, y se podría pensar que ésta fue una estrategia exitosa dada la repetitiva colaboración de algunos donantes como Tomás Mazzanti, Leopoldo Echeverría o José Sors que aparecen varias veces mencionados.

Finalmente, si bien las estrategias de aumento de las colecciones fueron positivas (cada nuevo informe expresa el aumento numérico de los objetos que forman parte del museo), a partir de las críticas expresadas por Holmberg, puede observarse que una vez abandonado el museo por la figura de su creador, su estado y sus actividades decaen y entran en lo que Ambrosetti describió como "vida anémica", y en definitiva, no contribuyeron a la supervivencia de los museos como instituciones. 


\section{Bibliografía}

Ambrosetti, Juan Bautista. 1893. El Museo de Entre Ríos. Datos sobre su fundación y desarrollo. Boletín del Instituto Geográfico Argentino. Tomo XIV. 131- 140.

1893b. Sobre una colección de alfarerías minuanes recogidas en la provincia de Entre Ríos. Boletín del Instituto Geográfico Argentino. Tomo XIV. 242-268.

1916. Prof. Pedro Scalabrini. Fundador y director de los Museos provinciales de Entre Ríos y Corrientes. Imprenta Coni. Buenos Aires.

Bosch, Beatriz. 1993. Irradiación del normalismo paranaense. Investigaciones y Ensayos. № 43. Enero- diciembre. Academia Nacional de la Historia. 209-235.

Cáceres Freyre, Julián. 1967. Juan B. Ambrosetti. Ediciones Culturales Argentinas. Dirección General de Difusión Cultural. Subsecretaría de Cultura. Subsecretaría de Cultura. Secretaría de Estado de Cultura y Educación. Buenos Aires. 149 pp.

Gabardini, Malvina Antonietta de. 1994. El movimiento positivista en la provincia de Corrientes: una revisión de la bibliografía sobre el tema. Revista Irice. $N^{\circ} 8$. abr. Instituto Rosario de Investigaciones en Ciencias de la Educación. Universidad Nacional de Rosario. CONICET. Rosario. P. 154- 168.

1995. Revista La Escuela Positiva: Corrientes 18951899: introducción e indices. Ediciones Culturales y Educativas del Chaco. Resistencia. $161 \mathrm{p}$.

Mantegari, Cristina. 2000. Museos y Ciencias: Algunas cuestiones historiográficas. En: Monserrat, Marcelo (comp.) La ciencia en la Argentina entre siglos. Textos, contextos e instituciones. Manantial. Buenos Aires. 297- 308.

Martínez Paz, Fernando. 2001. Enseñanza primaria, secundaria y universitaria (1862-1914). En: Academia Nacional de la Historia. Nueva Historia de la Nación Argentina. T. 6. Planeta. Buenos Aires. 277- 307.

Petriella, Dionisio y Sosa Miatello, Sara. 1976. Diccionario biográfico ítaloargentino. Asociación Dante Alighieri. Buenos Aires. 771 p. 
Podgorny, Irina y Lopes, Margaret. 2008. El desierto en una vitrina. Museos e historia natural en la Argentina, 1810-1890. Limusa. México. $279 \mathrm{pp}$.

Podgorny, Irina. 2009. El sendero del tiempo y de las causas accidentales. Coleccionistas y trabajo de campo en la constitución de la arqueología en el Plata (1870-1910). Prohistoria. Rosario. En prensa.

Scalabrini, Pedro. 1884. Conferencia del 6 de enero. Sección Entre Ríos del Instituto Geográfico Argentino. Boletín del Instituto Geográfico Argentino. Tomo V. 15-19.

1886. Museo Provincial de Entre Ríos (Cartas del profesor Scalabrini). En: Anales de la Sociedad Científica Argentina. Tomo XXII. Segundo Semestre.

1897. Nuevas cartas científicas. En: Revista de la Escuela Positiva. № 25 al 32 .

1898. Nueva cartas científicas. En: Revista de la Escuela

Positiva. № 3

\section{Fuentes consultadas}

El Litoral y La Libertad. Archivo General de la Provincia de Corrientes (AGPC).

Inventarios del Museo de Entre Ríos. Archivo General de Entre Ríos (AGER). 
12.

\section{A coleção do Museu de Astronomia e Ciências Afins}

Marcio Ferreira Rangel

No período dos Estados Modernos, a constituição de coleções históricas e artísticas nacionais, que compõem um patrimônio nacional, apresenta-se como uma prática característica destes governos que através de determinados agentes, recrutados entre intelectuais e com base em instrumentos jurídicos específicos, delimitam um conjunto de bens no espaço público (Fonseca, 1997, p.11). De acordo com a autora, o universo dos patrimônios históricos e artísticos nacionais se caracteriza pela heterogeneidade dos bens que o integram, sendo esta heterogeneidade marcada pela concepção de patrimônio e cultura adotada pelos agentes formadores.

$O$ ato de colecionar realça os modos como os diversos fatos e experiências são selecionados, reunidos, retirados de suas ocorrências temporais originais, e como eles recebem valor duradouro em um novo arranjo. Coletar, pelo menos no ocidente, onde geralmente se pensa no tempo como linear e irreversível, pressupõe resgatar fenômenos da decadência ou perda histórica inevitáveis. A coleção teoricamente contém o que merece ser guardado, lembrado e entesourado. Para Huyssen (1997, p. 123), no mundo moderno os museus são instituições pragmáticas que colecionam, salvam e preservam aquilo que foi lançado aos "estragos" da modernização.

Os objetos museológicos podem ser compreendidos como objetos no museu e na "organicidade" das coleções, onde foram desprendidos de suas funções originais. A nova relação com o presente se faz com associações estreitas com o seu semelhante, isto é, o objeto que compõe a mesma coleção insere-se na categoria complementar ao quebrar sua mera existência na cadeia produtiva econômica e ao dotar-se de uma aura no espaço museológico. 
A falta de uma concepção clara do que possui valor histórico, artístico e científico, do que pode ser considerado patrimônio, também deve ser visto como um elemento determinante na heterogeneidade de algumas coleções. Este aspecto chama a atenção para o fato de que estes bens pertencem, enquanto signos, à sistemas de linguagens distintas: à arquitetura, às artes plásticas, à musica, à etnografia, à arqueologia e à ciência. Cada um desses sistemas tem, por sua vez, suas especificidades e seu modo próprio de funcionamento enquanto código. Alem disso, esses bens cumprem funções diferenciadas na vida econômica e social. É nesta perspectiva que proponho a análise das coleções do Museu de Astronomia e Ciências Afins.

\section{A criação do Museu}

Ao pesquisar a construção e a formação das coleções museológicas do Museu de Astronomia e Ciências Afins - MAST, além de aprofundar o conhecimento sobre o processo de criação do Museu e a trajetória de seu acervo, estou simultaneamente analisando os personagens, grupos e instituições que as formaram. Há princípios atrás da organização destas coleções que podem reproduzir valores, ideologias e modelar narrativas.

Com a intenção de propor ações preservacionistas no campo das ciências, em 1982 um grupo de pesquisadores do CNPq inicia, no âmbito do Observatório Nacional $(\mathrm{ON})$, o Projeto Memória da Astronomia e Ciências Afins no Brasil (PMAC). Ao apresentar a proposta de criação do Museu, indicam que esta iniciativa tem por objetivo "dotar o país de uma instituição nos moldes dos museus de ciência há muito existentes no exterior: Palais de la Découverte, de Paris; Science Museum, de Londres; o complexo museológico do Smithsonian Institution; os museus de ciência da Índia, reunidos sob o National Council of Science Museums e o Singapore Science Center ${ }^{1 "}$. Neste mesmo ano, com a colaboração da Superintendência de Museus do Estado do Rio de Janeiro, o Arquivo Nacional, o Programa de Engenharia Metalúrgica da COPPE/UFRJ e o Núcleo de História da Ciência e da Tecnologia, do Departamento de História da Universidade de São Paulo, o grupo (PMAC) realizou as seguintes atividades: exposição comemorativa do Centenário da Passagem de Vênus (1882-1982) e a Mesa Redonda Preservação da Cultura Científica

1 Projeto Memória da Astronomia e Ciências Afins no Brasil. Museu de Ciência: proposta de criação. Rio de Janeiro, ago. 1983. Cópia (Arquivo MAST). 
Nacional ${ }^{2}$. Esta mesa tinha por objetivo discutir os caminhos a serem adotados na preservação do patrimônio científico nacional, tendo neste momento como foco o patrimônio sobre a guarda do Observatório Nacional.

No ano seguinte, em 1983, um grupo de intelectuais preocupados com a preservação "dos marcos históricos que testemunham a vocação criadora da inteligência brasileira nos domínios da ciência", solicita o tombamento "do sítio onde se acha localizado o Observatório Nacional, Rio de Janeiro, assim como de todo o acervo histórico daquela tradicional instituição de pesquisa, que inclui documentos, instrumentos e um conjunto de edificações datado do início do século"3. Entre eles destacamos: Carlos Drummond de Andrade, Oscar Niemeyer, Franklin de Oliveira, Nelson Werneck Sodré, Roberto Marinho, Mário Novelo, Mário Schenberg, Josué Monteiro, Plínio Doyle, Antônio Houaiss, Francisco de Assis Barbosa, Austragésilo de Athayde, Afrânio Coutinho, Lyra Tavares, Orígenes Lessa, Cyro dos Anjos, Carlos Chagas, Shozo Motoyama, Luis Pinguelli Rosa, Fernanda de Camargo A. Moro e Crodowaldo Pavan.

Como resultado desta articulação, a então Secretaria do Patrimônio Histórico e Artístico Nacional, em 1984, determinou o tombamento dos prédios e do acervo científico do Observatório Nacional e sugeriu a criação do museu. Em 1985 ocorre o tombamento provisório e é criado o Museu de Astronomia Ciências Afins.

Somente no dia 14 de agosto de 1986 ocorre o tombamento definitivo do Museu (processo 1009-T-79) e sua inscrição nos Livros de Tombo Arqueológico, Etnográfico e Paisagístico (inscrição 095) e Histórico (inscrição 509), com a seguinte descrição:

"Situado em área com cerca de $40.000 \mathrm{~m}^{2}$, delimitada conforme poligonal descrita e constante do processo, bem como o acervo arrolado no anexo III do mesmo processo. Encontra-se hoje em São Cristovão,

2 Participaram desta mesa: Carlos Chagas Filho (Instituto de Biofísica da UFRJ); Crodowaldo Pavan (Presidente SBPC); Fernanda de C. Almeida Moro (Superintendência de Museus da FUNARJ); George Cerqueira Leite Zarur (Programa de Museus e Coleções Científicas do CNPq); Lício da Silva (Departamento de Astrofísica do Observatório Nacional); Mário Schenberg (Instituto de Física da USP); Maurício Mattos Peixoto (Presidente da Academia Brasileira de Ciências); José Leite Lopes (Físico Centro Brasileiro de Pesquisas Físicas - CBPF); Luiz Muniz Barreto (Diretor do Observatório Nacional); Ronaldo R. de Freitas Mourão (Projeto Memória do Observatório Nacional); Shozo Motoyama (Núcleo de História da Ciência e da Tecnologia da USP) e Simão Mathias (Instituto de Química da USP).

3 Projeto Memória da Astronomia e Ciências Afins no Brasil. Museu de Ciência: proposta de criação. Rio de Janeiro, ago. 1983. Cópia (Arquivo MAST). 
tendo funcionado no alto do Morro do Castelo, em edificação do colégio que fora dos jesuítas. Diversos acréscimos foram sendo realizados a fim de atender à modernização das pesquisas científicas. A partir da década de 1980, com a construção de um novo observatório na Serra da Mantiqueira, sul de Minas, foi mantido em São Cristovão apenas alguns programas, como o serviço de hora e o atendimento às áreas de ensino. O edifício principal, que abriga a administração foi projetado pelo arquiteto Mário de Souza inspirado no prédio central do observatório de Paris. As demais edificações, sejam as cúpulas para observação, as novas instalações para o serviço de hora ou a antiga residência do diretor foram posteriores dos astrônomos, são construções feitas sem nenhuma preocupação estética. Apresenta uma coleção de objetos científicos como lunetas e telescópios de grande valor para a história cientifica do Brasil. A densa arborização que encobre parte considerável do campus tem grande valor paisagístico ${ }^{4 "}$.

Deve-se ressaltar que os bens que vieram a fazer parte do acervo perderam o seu valor estético, de uso, decorativo e econômico e passaram a apresentar, valor histórico, valor de documento. Segundo K. Pomian (1984, p. 53), qualquer conjunto de objetos naturais ou artificiais, mantidos temporária ou definitivamente fora do circuito das atividades econômicas, sujeitos a uma proteção especial num local fechado preparado para esse fim, e expostos ao olhar público, pode fazer parte de uma coleção. Para Jean Baudrillard (1993, p. 94), o objeto puro, privado de função ou abstraído de seu uso, toma um estatuto estritamente subjetivo: torna-se objeto de coleção. Cessa de ser tapete, mesa, bússola, teodolito, luneta ou sextante para se tornar objeto. $O$ ato de colecionar realça os modos como os diversos fatos e experiências são selecionados, reunidos, retirados de suas lógicas temporais originais, e como eles recebem um valor duradouro num novo arranjo (Rangel, 2000, p. 78). A criação e a trajetória do Museu de Astronomia e Ciências Afins está relacionada ao desejo/discurso de preservação de "um patrimônio" em risco. Neste sentido o processo de criação do MAST é o resultado direto do medo da perda.

4 Arquivo Noronha Santos. Livros de Tombo.Capiturado em 02 de maio. Disponível on-line na fonte: http://www.iphan.gov.br/ans/inicial.htm 


\title{
Entre Teodolitos, Lunetas e Sextantes ${ }^{5}$.
}

$\mathrm{Na}$ análise do acervo científico, apresento como recorte a coleção de instrumentos oriunda do antigo Observatório Nacional, composta por 1051 objetos distribuídos nas seguintes categorias: Astronomia; Cálculo e Desenho; Eletricidade e Magnetismo; Geodésia e Topografia; Geofísica e Oceanografia; Medição do Tempo; Meteorologia; Metrologia; Navegação; Óptica; Química; Termologia e Acessórios de Astronomia e Geodésia.

Termômetros, cronômetros, barômetros, sismógrafos, teodolitos, espectroscópios, lunetas e altazimutes apresentam-se como testemunhos materiais da cultura e memória cientifica nacional e de práticas cientificas desenvolvidas no Brasil.

É possível perceber na Mesa Redonda de 1982, que a existência deste acervo influenciou no modelo de instituição museológica adotada. Ao analisar a concepção de museologia e museu, presente no momento de criação da instituição, é possível verificar que as propostas transitavam entre um centro de ciência, modelo adotado na década de 80 do século XX, por diversas instituições ${ }^{6}$ e um modelo clássico de museu que tivesse como eixo norteador de sua estruturação o acervo. $\mathrm{O}$ documento enfatizava que

\begin{abstract}
"longe de caracterizar-se como depósito de peças antigas, expostas estaticamente, o Museu deve buscar sempre arrojadas soluções estéticas e pedagógicas de modo a motivar o público visitante, estimulando-o intelectualmente para participar ativamente nas demonstrações dos fenômenos naturais básicos e dos encadeamentos do pensamento científico ${ }^{7 "}$.
\end{abstract}

5 TEODOLITOS: Instrumento utilizado para medir ângulos horizontais e verticais; LUNETAS: Instrumento utilizado em observações celestes; SEXTANTE: Instrumento utilizado para medir distâncias angulares. Empregado na navegação astronômica para medir a altura de um corpo celeste. Pode ser utilizado em terra com o auxílio de um horizonte artificial.

6 Na década de 80 podemos citar a criação das seguintes instituições: Museu Dinâmico de Campinas; Espaço Ciência Viva no Rio de Janeiro; Estação Ciência de São Paulo; Estação Ciência da Paraíba entre outros.

7 Projeto Memória da Astronomia e Ciências Afins no Brasil. Museu de Ciência: proposta de criação. Rio de Janeiro, ago. 1983. Cópia (Arquivo MAST). 
Neste trecho podemos verificar a ênfase dada aos museus que adotavam os aspectos "interativos" em suas exposições e a critica as instituições museológicas denominadas tradicionais na sua forma de comunicação. A proposta de museu efetivada optou por uma instituição de caráter híbrido, ou seja, adotou uma linguagem expositiva de centro de ciência e o acervo ficou localizado em uma reserva técnica visitável. Tal medida evidenciou a dificuldade da instituição em trabalhar com este conjunto de instrumentos que esteve diretamente relacionado com os argumentos de criação do Museu. No decorrer dos anos, em diferentes momentos de crise institucional, o acervo de instrumentos científicos ${ }^{8}$ foi um dos elementos argumentativos de defesa da instituição.

\section{Considerações finais}

No processo de construção do patrimônio científico (Choay, 2001, p. 11), deve-se compreender o vasto conjunto de bens materiais e simbólicos produzidos ou utilizados ao longo do trajeto da produção e difusão do conhecimento. Consideramos os objetos que formam esta coleção, indícios ou pistas materiais (Ginzburg, 1989, p. 143) de pesquisas pregressas, uma espécie de biografia institucional, como um livro que contivesse a síntese do museu. Além de patrimônio científico, as coleções são suportes de memória, pois nos remetem a procedimentos, práticas científicas e conceitos de nosso passado remoto e recente. Apesar de possuir este forte laço com o nosso passado, as coleções científicas possuem um laço de igual intensidade com o futuro, quando consideramos as possíveis reestruturações conceituais que podem ocasionar.

O acervo museológico do MAST constitui o testemunho do conhecimento gerado pela pesquisa pregressa. No mundo contemporâneo, além das coleções científicas se colocarem como fonte crucial de informação para diferentes campos do saber, elas também se transformaram em herança cultural, em testemunho da rica história do descobrimento e da expansão da sociedade brasileira em seu território. Por maior valor intrínseco que possuam os objetos de uma coleção, estes só passam a adquirir status e expressão de herança cultural, depois de estudados e tornados acessiveis à coletividade. Foi com este olhar que estruturei este artigo, considerando estas coleções patrimônio científico, testemunho da consolidação da ciência e tecnologia no Brasil.

8 Junto com o acervo de instrumentos científicos, o acervo histórico do arquivo do MAST também era apontado com uma das razões para a permanência da instituição. 
Considerando as coleções do MAST testemunhos materiais de práticas científicas de diferentes períodos, vejo como estratégico a pesquisa de sua formação. Desta poderemos gerar informações que alimentarão outras ações estratégicas do Museu, tais como: o Thesaurus de Acervos Científicos em língua Portuguesa - projeto elaborado pela Coordenação de Museologia do MAST em parceria com o Museu de Ciência da Universidade de Lisboa (MCUL), que tem como objetivo desenvolver um tesauro terminológico para acervos de objetos científicos que possa constituir um instrumento de trabalho e de recuperação da informação, facilitando a comunicação entre os museus de ciência e técnica da esfera lusófona, especialmente Brasil e Portugal; a Política de Aquisição e Descarte de acervos: documento que norteia todo o processo de formação das coleções científicas do museu e a Reformulação da Exposição Permanente do Museu: projeto que apresenta a reformulação de todo o circuito expositivo do museu, tendo como um de seus princípios norteadores o acervo.

Não podemos ainda esquecer o papel que o Museu pode ocupar no âmbito do Ministério de Ciência e Tecnologia, como instituto orientador de políticas públicas de preservação para área de C\&T. Em suma, o que busquei apontar neste artigo foi à relevância do acervo do MAST como fonte de investigação para a museologia e para a historia das ciências. 


\section{Referências}

ARQUIVO MAST. Projeto Memória da Astronomia e Ciências Afins no Brasil. Museu de Ciência: proposta de criação. Rio de Janeiro, ago. 1983. Cópia

BAUDRILLARD, Jean. O sistema dos objetos. São Paulo: Perspectiva, 2002.

BENJAMIN, Walter. Passagens. Trad. de Irene Aron. Belo Horizonte: Editora da UFMG, 2006.

CHOAY, Françoise. A alegoria do patrimônio. São Paulo: Editora Unesp, 2001.

FONSECA, Maria Cecília Londres. O patrimônio em processo: trajetória da política federal de preservação no Brasil. $2^{\underline{a}}$ edição, Rio de Janeiro: Editora UFRJ; MINC- IPHAN, 2005.

GINZBURG, Carlo. Mitos, Emblemas, Sinais: morfologia da história. São Paulo: Companhia das Letras, 1989.

HYUSSEN, Andreas. Memórias do modernismo. Rio de Janeiro, UFRJ, 1997.

POMIAN, K. Coleção. In: ENCICLOPÉDIA Einaudi. Lisboa: Imprensa Nacional/Casa da Moeda, 1984. v. 1. p. 51-86.

RANGEL, Marcio Ferreira. A Formação do Acervo do Museu Histórico da Cidade do Rio de Janeiro: caos e memória. Dissertação de mestrado apresentada ao Programa de Pós-Graduação em Memória Social e Documento / Universidade Federal do Estado do Rio de Janeiro UNIRIO. Rio de Janeiro, 2000.

\section{Referências eletrônicas:}

Museu de Astronomia e Ciências Afins: http://www.mast.br/nav_h03. htm

Instituto do Patrimônio Histórico e Artístico Nacional: http://www.iphan. gov.br/ans/inicial.htm 


\title{
13.
}

\section{Centro de Documentação Digital em História da Ciência (cdhc)}

\author{
Adailton Ferreira dos Santos
}

A política nacional de desenvolvimento e incentivo à educação e à ciência tem valorizado, cada vez mais, os espaços científico-culturais, como, por exemplo, a criação de centros de documentação digital em história das ciências, através de suas agências de fomentos em todo o país.

Esses espaços são vistos, pelos órgãos de fomento, como locais de preservação da memória das ciências, de informação e também são ambientes que promovem atividades de divulgação científica que valorizam a interatividade, como locais de pesquisa e de formação de acervos temáticos de estudos no país².

No contexto dessa política, estamos desenvolvendo o Projeto Centro de Documentação Digital em História da Ciência na Universidade do Estado da Bahia (UNEB), instituição de ensino superior multi campi, formada por 24 campi, distribuídos, estrategicamente, em 24 municípios, ou seja, em todas as regiões da Bahia.

Em consonância com este modelo de Instituição de Ensino Superior multi campi, o Centro de Documentação Digital em História da Ciência pretende ser um espaço de pesquisa virtual (em rede via internet integrado a todos os campi e departamentos da universidade) e também presencial para a realização de pesquisas, preservação e recuperação de documentos.

1 Universidade do Estado da Bahia - UNEB. E-mail: aferro@gi.com.br

2 Os órgãos de fomentos têm apoiado a criação destes espaços no país. Vide CNPq/ SECIS/MCT/ FAPESB, $n \cong 064 / 2009$, p.1. 
O Projeto deste modo vem corroborar com o propósito da Universidade do Estado da Bahia que "tem entre seus objetivos, a difusão da educação superior na região, atendendo a necessidade de desenvolvimento integrado do Estado e as legítimas demandas das comunidades, com vista ao crescimento científico, técnico, cultural e tecnológico da Bahia"3.

As primeiras ideias de criação deste Centro de Documentação Digital em História da Ciência (CDHC) surgiram ao longo dos nossos estudos de doutorado no campo da História das Ciências, voltado para as ciências na Bahia ${ }^{4}$, e com a localização de documentos inéditos e de acervos do período imperial, em instituições de pesquisa no Brasil e no exterior.

Os Centros de Documentação em História da Ciência são instituições que reúnem tipos característicos de acervos sobre as ciências com finalidades específicas de preservação documental, de informação e de pesquisa ${ }^{5}$.

Com a definição de seu universo, de seu recorte temático e em consonância com seus objetivos o projeto prioriza a formação de arquivos temáticos, na área de sua especialização, notadamente no campo da história das ciências naturais, do período Brasil Imperial, século XIX, sobretudo da Bahia.

Nesse período, com a mudança de D. João VI e da Corte Portuguesa para essas terras, em 1808, e a adoção de medidas no campo político, econômico e social deram novos rumos para as ciências modernas no país. Entre essas medidas, destacamos a suspensão das barreiras legais, que impediam o desenvolvimento do território, ao abrir os portos à navegação estrangeiras e a revogação da lei que proibia a imprensa, criando condições para o desenvolvimento das ciências no Brasil ${ }^{6}$

Conforme Ferraz, nesse contexto "surgem as ciências modernas com a "implantação e difusão de espaços científicos" como a Biblioteca

3 A UNEB reafirma esse compromisso apoiando as várias iniciativas que surgem na instituição por ocasião da comemoração de seus 25 anos de existência em UNEB Prestação de Conta Exercício, Bahia, 2008. p.13

4 Estudamos atualmente as Teses Doutorais da Faculdade de Medicina da Bahia, do período imperial.

5 Tessitore, 2003, p.14

6 Ver explicações desse período em nosso estudo. Santos, A. F. Escola Tropicalista Baiana: Registro de uma Nova Ciência na Gazeta Médica da Bahia (1866-1889), 2008, pp. 19 e 40. 
Imperial, o Museu Real, o Horto Real e outras instituições na Capital do Império e também nas Províncias.

Notadamente, na Província da Bahia, em 18 de fevereiro deste mesmo ano, no campo das ciências naturais, cria-se a Escola de Cirurgia da Bahia7, no Hospital Real Militar8". Embora, antes desse período, em vários momentos, os pedidos da Câmara da Bahia, dos Jesuítas e de corporações, para criar instituições científicas nessa terra foram negados pela Coroa em Portugal, com "propósito de impedir o estabelecimento de instituições que pudessem rivalizar com as existentes na Metrópole"9 e, assim, "manter a dependência da colônia"10.

Na sequência, com a complexidade do cenário político e econômico o Brasil, torna-se a capital do Reino Unido de Portugal-Brasil-Algarves, em 1815, e, no campo das ciências, surgem as primeiras reformas, entre elas, a transformação da Escola de Cirurgia em Colégio de Anatomia e Cirurgia da Bahia ${ }^{11}$. Assim, implantam-se o Plano de Estudos das Ciências Médicas e criam-se disciplinas como anatomia, patologia, fisiologia, laboratórios, salas de operações e a botica. Contratam-se professores e formam-se Cirurgiões para todo o país. Em seguida, são criadas as disciplinas de química, em 181712, com instruções para atender as necessidades da agricultura, do comércio e da indústria, e de obstetrícia, em $1818^{13}$ para melhoria da saúde da população. Embora necessárias essas mudanças não são suficientes.

Com as mudanças e transformações em todos os setores, 'cresce o comércio e os trabalhadores da zona rural se transferem para a capital da Província"14, por outro lado, "aumentam-se os casos de doenças e epidemias. Essa situação leva à morte milhares de trabalhadores e escravos que são a força da economia. É ínfimo o número de médicos e de hospitais'15.

7 É criada com a Carta Régia de 18 de fevereiro, de 1808.

8 No antigo prédio do extinto Colégio dos Jesuítas, no terreiro de Jesus, em Salvador.

9 Alfonso-Goldfarb e Ferraz, 2002, p.4

10 Azevedo, 1971, p.532.

11 A Carta Régia de 29 de dezembro também ampliou e transferiu a Escola para o Hospital da Santa Casa da Misericórdia.

$12 \mathrm{Na}$ Carta Régia, de 28 de janeiro de 1817, exige-se que o aluno de qualquer curso tenha conhecimento desta ciência.

13 Ainda esta Carta Régia, de 18 de fevereiro de 1818, autorizou a contratação de novos professores.

14 Ver a descrição sobre a sociedade baiana, no século XIX em obra de MATTOSO, 1992, p. 435.

15 Pronunciamento do professor e médico da Faculdade de Medicina da Bahia, Amaral, "Conferência na Sessão do Instituto Bahiano de História da Medicina em 1948", in Arquivo do Instituto Baiano de 
De todo modo, a Escola de Anatomia e Cirurgia da Bahia convive com dificuldades de várias ordens como a falta de material para o ensino médico e de equipamentos, além das condições precárias da saúde pública.

A partir da terceira década do século XIX, são feitas novas mudanças com a reforma das ciências médicas, em 1832. A Escola de Anatomia e Cirurgia é transformada em Faculdade de Medicina da Bahia ${ }^{16}$. Entre as modificações, criam-se os cursos de Farmácia, Obstétrica e de Medicina ${ }^{17}$.

Nesse cenário, na segunda metade do século, surge a chamada 'Escola Tropicalista Baiana'18, em 1866, formada por médicos independentes, que realizavam pesquisas originais sobre as doenças tropicais ${ }^{19}$ e divulgavam no periódico Gazeta Médica da Bahia ${ }^{20}$.

A abordagem desse período do século XIX, feita, aqui, de modo breve, teve o propósito de apresentar um panorama que aponta para as fontes documentais e representativas para a história das ciências naturais, na Província da Bahia. Conforme Fonseca o historiador, notadamente aquele que investiga a história das saúdes no país, depara-se com um conjunto de fontes bastante amplas e diversificadas. E é justamente desta convergência de diferentes testemunhos que viabilizamos a investigação histórica. Esta diversidade de registros e testemunhos caracteriza o repertório de fontes potencialmente relevantes para a história das ciências.

Esse conjunto de fontes são documentos. "É documento o livro, o artigo de revista, o periódico, o prontuário médico, a carta, a legislação, os objetos utilizados, etc. Entretanto, para que os documentos cumpram sua função social, científica e histórica é necessário que estejam preservados, organizados e acessíveis" 21 .

Medicina, Vol. I, p. 42.

16 Conforme a Carta Régia de 1832 que também, criou o título de doutor no Brasil, expedido pelas Faculdades, ao aluno que defendesse uma tese na conclusão o curso superior.

17 Ibd., p. 3.

18 Santos, op. cit.,p.71.

19 Esta denominação é dada posteriormente, na época chamavam-se de doenças regionais.

20 A Gazeta Médica da Bahia é fundada em 10 de julho, de 1866, em Salvador, pela Escola Tropicalista Baiana e tornou-se um importante meio de divulgação dos estudos sobre doenças tropicais.

21 Ver Belloto, 2004, p. 24. 
O projeto, Centro de Documentação Digital em História da Ciência $(\mathrm{CHC})$, se alinha a discussão proposta por Belloto e, por seu modo, toma com base a "concepção de unidades de informação virtuais para a preservação da memória (das ciências naturais na Bahia), onde os documentos eletrônicos exercem função primordial, pois estas fontes documentais (imagéticas) ampliam a percepção da realidade científica tradicionalmente exposta nos documentos" 22 .

Deste modo, as informações serão organizadas num banco de dados, em acervos temáticos e disponibilizadas em meio virtual, e também em forma digital, microformas e microfichas, no campus I, da Universidade do Estado da Bahia (UNEB), na cidade de Salvador, Bahia.

As experiências no exterior e também no Brasil com espaços como Centros de Documentação Digitais em História da Ciência têm sido vistas como uma importante contribuição para o conhecimento da ciência, da tecnologia e da inovação produzidas em uma região e constituem iniciativas fundamentais para a informação e o desenvolvimento local e nacional. Esses espaços têm recebido apoios dos governos, universidades, institutos de pesquisa e órgãos de fomentos. Nesse contexto, a pesquisa e divulgação da ciência e da tecnologia se colocam como importantes campos de ação, contribuindo para a melhoria de qualidade da educação23.

Os Centros de Documentação em História das Ciências, no Brasil, ainda são relativamente poucos e têm ainda pequena capacidade para promover a pesquisas e a divulgação científica em grande escala. Enquanto que em países desenvolvidos os centros de documentação são organismos de grande contribuição de pesquisas ${ }^{24}$.

Embora recentes, temos, no país, centros e grupos de pesquisa de história das ciências, bem sucedidos, que desenvolvem pesquisas no Brasil e no exterior. Um desses Centros de História da Ciência é o Centro Simão Mathias de História da Ciência (CESIMA), na Pontifícia Universidade de São Paulo (PUC), São Paulo, criado em 1994. Esta entidade possui um acervo com milhares de títulos, além de importantes pesquisadores e publicações de livros, periódico e programa de pós-graduação com doutorado, mestrado e especialização de história da ciência ${ }^{25}$.

22 Ver maiores explicações em Tessitore, 2003, p. 9.

23 CNPq/SECIS/MCT, op.cit., p.2.

24 Ibid.

25 Informações disponíveis em no site <http://www.pucsp.br/pos/cesima/>, acesso em 13 de junho 2010. 
Os grupos de pesquisa, por seu modo, estão na maior parte, ligados a instituições de ensino superior e/ou a programas de pós-graduação e representam a diversidade de áreas que dialogam com a história das ciências. Eles realizam pesquisas, no país e no exterior, possuem acervos, publicações de livros individuais e em parcerias, têm periódicos e desenvolve formação de pessoal.

Na região sul-sudeste estes grupos estão alocados em instituições como a Universidade de São Paulo (USP), São Paulo, da Universidade Estadual de Campinas (UNICAMP), Campinas-SP, da Universidade Federal do ABC (UFABC), Santo André-SP, da Universidade Federal do Rio de Janeiro (UFRJ), da Casa Osvaldo Cruz (FIOCRUZ) e do Museu de Astronomia e Ciências Afins (MAST), situados no Rio de Janeiro, além da Universidade Federal do Paraná, (UFPR), Curitiba.

E na região norte-nordeste, estes grupos são poucos e fazem parte de projetos na Universidade Federal de Pernambuco (UFPE), em Recife e na Universidade Federal da Bahia (UFBA), no município de Salvador.

Outra importante entidade e que representa a institucionalização da área no país, é a Sociedade Brasileira de História da Ciência (SBHC), fundada em 1983, com sede no Rio de Janeiro. Esta entidade reúne pesquisadores importantes de instituições de toda parte do Brasil, possui periódico e promove a cada dois anos o Seminário Nacional de História da Ciência e da Tecnologia para discussão e debates de temas da área. A SBHC destacou-se no apoio ao desenvolvimento de pesquisa na área e na contribuição para a formação de pesquisadores ${ }^{26}$.

Contudo a área de história das ciências apresenta distribuição muito desigual pelo território nacional; a maioria está na região sul-sudeste do país, a desigualdade de instituições nesse campo do saber entre as regiões. Assim a iniciativa de criação desse Centro em História da Ciência, na Universidade do Estado da Bahia, será uma contribuição importante para a região norte-nordeste do país.

Igualmente importante para o desenvolvimento dessa área do conhecimento, nessa região, é o incentivo e investimento governamental, através de agências de fomentos e apoio à formação de pessoal, de grupos de pesquisa e de centros de documentação.

Assim, o objetivo geral deste projeto é a criação do Centro de Documentação Digital em História da Ciência (CDHC), na Universidade do Estado da Bahia, para preservação de documentos sobre as ciências

26 Informações disponíveis em no site < http://www.sbhc.org.br/ >, acesso em 13 de junho 2010. 
naturais do século XIX, da Província da Bahia; informação e pesquisa virtual e presencial.

Em decorrências desses propósitos são objetivos específicos: a) reunir em acervos temáticos coleções de documentos, periódicos, livros, manuscrito, legislações, cartas e imagens, em formas digitais; b) divulgar o acervo para instituições de pesquisas e à sociedade.

Como um centro de documentação em história da ciência tem por objetivo a preservação da memória, a informação e a pesquisa histórica, a natureza de seu acervo será heterogênea. Nesse sentido, esse tipo de instituição reúne vários tipos de acervos ${ }^{27}$.

Porquanto, um centro de documentação, apesar de ser um organismo único e peculiar, pode reunir diversos tipos de documentos em seu acervo, sejam eles arquivísticos, bibliográficos ou musicológicos. A forma como esses documentos são reunidos e disponibilizados é que possibilita aos centros cumprirem suas funções de preservação documental, informação e apoio à pesquisa. ${ }^{28}$

A metodologia adotada para o desenvolvimento desse projeto privilegia as abordagens que contemplam as discussões de pesquisadores da área sobre ciência e sociedade. Por outro lado, é fundamental o conhecimento das técnicas de implementação de centros de documentação digital em história da ciência e memória ${ }^{29}$.

Também é necessário uma revisão bibliográfica referente ao assunto, na qual vários aspectos serão contemplados, dando-se ênfase ao panorama histórico, cultural e institucional.

Assim estabelecemos, inicialmente, algumas etapas de construção e especificamos quais as atividades regulares a serem executadas de acordo com as metas a serem alcançadas.

Nesse sentido, elegemos como prioridades a localização e identificação de documentos, do século XIX, para formação de um dos acervos temáticos sobre as ciências médicas na Bahia. Com esse intuito, realizamos pesquisas em instituições no Brasil como o Arquivo Público do Estado da Bahia e a Biblioteca da Faculdade de Medicina, na Universidade Federal da Bahia, em Salvador, no Centro Simão Mathias em História da Ciência (CESIMA) e nas Bibliotecas das Faculdades de Medicina e Saúde

27 Tessitore, op. cit., p. 18

28 Ibid., p.15.

29 Ibid., p.20. 
Pública da Universidade de São Paulo (USP), em São Paulo, na Biblioteca de Saúde Pública da Universidade Federal do Rio de Janeiro (UFRJ) e na Biblioteca Nacional no Rio de Janeiro, no Rio de Janeiro. No exterior pesquisamos na Biblioteca da Torre do Tombo e na Biblioteca da Faculdade de Medicina da Universidade de Coimbra, em Portugal.

Emseguida selecionamose adquirimosnessas instituições documentos sobre as ciências médicas da Bahia, tais como Cartas Régias de 1808 a 1854, Correspondências e Decretos dos Governadores da Província, Legislações sobre as Reformas das Ciências Naturais, Manuscritos, Instruções sobre o Ensino Superior, Memoriais da Faculdade de Medicina da Bahia, Planos de Ensino da Faculdade, Prontuários Médicos, Modelos de Aulas dos Lentes, Relatórios de Viagens de Comissões Científicas à Europa, Atas de Reuniões da Congregação da Faculdade, Livros, Artigos sobre as Doenças Tropicais, publicados pela Escola Tropicalista na Gazeta Médica da Bahia, Teses Doutorais dos Médicos da Faculdade de Medicina e Manuscritos, além de outros documentos raros.

Na sequência, iniciaremos o trabalho de caracterização dessa documentação para compor cada acervos temáticos e passaremos para a etapa seguinte, isto é, a digitalização, uma vez que a maior parte dos documentos encontra-se em microfichas, filmes e/ou fotografias.

Embora o centro se encontre em processo de estabelecimento já é possível, mesmo de forma precária, a realização de consultas à parte desse acervo documental. Estamos utilizando esse material para nossa pesquisa de doutorado ${ }^{30} \mathrm{em}$ história da ciência.

A instalação desse espaço, organização dos acervos temáticos e funcionamento, em rede virtual de informação, possibilitará o desenvolvimento de pesquisas em história das ciências naturais em todos os 24 campi da UNEB.

Um Centro de Documentação de História da Ciência tem grande importância, nesse contexto de desenvolvimento da ciência, tecnologia e inovação para pesquisa e melhoria no ensino. No caso da Universidade do Estado da Bahia, instituição multi campi, este empreendimento beneficiará toda a região baiana. A comunidade acadêmica nos diversos municípios, pesquisadores, professores, alunos e interessados nesse campo do saber, terão acesso aos acervos e, por outro lado, poderão gerir melhor o tempo e poupar recursos financeiros com viagens $\mathrm{e}$

30 Particularmente as Tese Doutorais da Faculdade de Médica, da segunda metade do século XIX. 
hospedagens para realização de pesquisas em bibliotecas e arquivos públicos.

Entendemos que a Universidade do Estado da Bahia (UNEB) ao apoiar este projeto contribui para promover o acesso à informação e também cria condições para a produção do conhecimento e exerce sua responsabilidade social ao valorizar a memória institucional e coletiva como diz Bellotto ${ }^{31}$.

Por conseguinte, o trabalho para o estabelecimento do Centro de Documentação em História da Ciência (CDHC), tem sido possível devido ao apoio de instituições de pesquisas como o Centro Simão Mathias em História da Ciência (CESIMA), as Bibliotecas das Faculdades de Medicina e Saúde Pública da USP, a Universidade Federal do Rio de Janeiro (UFRJ), a Biblioteca Nacional no Rio de Janeiro, a Biblioteca da Torre do Tombo e a Universidade de Coimbra, em Portugal que têm possibilitado o acesso aos seus acervos e a CAPES e Universidade do Estado da Bahia com o financiamento dos estudos. A todos nossos agradecimentos.

31 Bellotto, op. cit., p. 51. 


\section{Referências bibliográficas}

ALFONSO-GOLDFARB, A. M. \& C. A. Maia, orgs. História da ciência: o mapa do conhecimento. Rio de Janeiro/São Paulo, Expressão e Cultura/ Edusp, 1995.

AMARAL, H. de. "Arquivo do Instituto Baiano de Medicina", Salvador, BA, Vol. I, 1948.

AZEVEDO, Fernando de. Org., As Ciências no Brasil. São Paulo, Melhoramento, 1953.

FERRAZ, H. Márcia \& A. M. Alfonso-Goldfarb. Raizes históricas da difícil equação institucional da ciência no Brasil. Revista São Paulo em Perspectiva, SP, 3, (2002): 3-14.

As Ciências em Portugal e no Brasil (1772 - 1822): o texto conflituoso da química. São Paulo, EDUC/FAPESB, 1997.

ANDRADE, Ana Célia Navarro. "Microfilmagem de Documentos em Arquivos Permanentes". (apostila), São Paulo, 1995.

BELLOTTO, Heloísa Liberalli. Arquivos Permanentes: Tratamento Documental. 2. ed. rev. e aum. Rio de Janeiro: FGV, 2004.

; CAMARGO, Ana Maria de Almeida. Dicionário de Terminologia Arquivistica. São Paulo: AAB-SP/SEC, 1996.

BECK, Ingrid. Manual de Conservação de Documentos. Rio de Janeiro: Arquivo Nacional, 1995.

Carta Régia de 18 de fevereiro, de 1808. Colleção de Leis do Brasil Império, 1808.

Carta Régia de 29 de dezembro, de 1815. Colleção de Leis do Brasil Império, 1815.

Carta Régia, de 28 de janeiro de 1817. Colleção de Leis do Brasil Império, 18178.

Carta Régia, de 18 de fevereiro de 1818, Colleção de Leis do Brasil Império, 1818. 
Carta Régia de 03 de outubro de 1832 Colleção de Leis do Brasil Império, 1832.

CORTEZ, Maria Tereza. Centro de Documentação: Implantação com Microcomputador. 2. ed. revista e ampliada. São Paulo: s.p.c., 1987.

CNPq/SECIS/MCT/Fundações Estaduais de Amparo à Pesquisa, Brasília: "Edital, no 064," 2009.

FONSECA, M. R. "Fontes para a História das Ciências da Saúde no Brasil (1808-1930)". Revista de Manguinhos, Rio de Janeiro, (2002): 275-88, vol. 9.

FLORES, Jorge. "How to build an interactive science center". Palestra proferida no Seminário Internacional sobre Implantação de Centros e Museus de Ciências. Rio de Janeiro: UFRJ, ago. 1999, 3 p. xerox.

FRIEDMAN, A. J. "Planning an academic center to develop staff and conduct research for science centers and museums". Palestra proferida no Seminário Internacional sobre Implantação de Centros e Museus de Ciências. Rio de Janeiro: UFRJ, ago. 1999, 10 p.

GASPAR, Alberto. Museus e Centros de Ciências: conceituação e proposta de um referencial teórico. São Paulo: Universidade de São Paulo, 1993. 173 p. (Tese de doutorado)

GANGUILHER, Georges. Ideologia e Racionalidade nas ciências da vida, Lisboa, Edições 70, 1977.

Gazeta Médica da Bahia, 10 de julho, Salvador, BA, 1866

LE GOFF, Jacques. História e Memória. Campinas, SP: Editora da UNICAMP, 1994.

MANGUEL, Alberto. Lendo Imagens: uma história de amor e ódio. São Paulo: Companhia das Letras, 2001.

MATTOSO, K. Q. Bahia Século XIX, Uma Província no Império. Rio de Janeiro, Nova Fronteira, 1992.

SANTOS, A. F. "Escola Tropicalista Baiana: Registro de uma nova ciência na Gazeta Médica da Bahia (1866-1889)". Dissertação de Mestrado, Programa de Pós-Graduação em História da Ciência, PUCSP, 2008, p. 42. 
SILVA, Zélia Lopes da. Arquivos, Patrimônio e Memória: trajetórias e perspectivas. São Paulo: UNESP, 1999.

TESSITORE, Viviane. Como Implantar Centros de Documentação. São Paulo: Arquivo do Estado, Imprensa Oficial do Estado de São Paulo, 2003.

UNEB, Relatório de Prestação de Conta Exercício, Salvador, Bahia, 2008. 


\title{
14.
}

\section{Orquidofilia com ciência: colecionismo e divulgação na revista Orquídea}

\author{
Valéria Mara Silva \\ Bernardo Jefferson de Oliveira
}

fenômeno social do colecionismo nos remete a uma série de circunstâncias históricas dadas por diferentes povos, sua geografia e hábitos culturais. Uma imensa gama de artefatos pode compor uma coleção, sendo esta uma instituição universalmente difundida e assentada na oposição entre o visível e o invisível. A dimensão ordenadora do colecionismo opera de tal maneira que os objetos perdem sua utilidade e sob nova disposição são "expostos ao olhar". Isso implica em cuidados dos mais diversos - confecção de álbuns, fotos, vitrines - além disso, revela um movimento duplo: ao privilegiar determinados objetos, os homens são de certa maneira moldados por eles, uma vez que os objetos impõem comportamentos aos colecionadores. ${ }^{3}$

A análise que nos propomos a fazer se dedica a um tipo de colecionismo, a orquidofilia. O ideário, as práticas e projetos ligados a essa atividade serão conduzidos a partir da revista Orquídea (1938-1974), uma publicação elaborada por amadores e principal instrumento de comunicação das sociedades orquidófilas que começaram a proliferar no Brasil a partir de fins da década de 1930.

Embora o cultivo de flores para fins ornamentais não possa ser datado, é possível contextualizado por meio das relações entre ciência, contatos intercontinentais, mercado e colecionadores. Colecionar e

1 Doutoranda do Programa de Pós-graduação em História, UFMG.

Email: valeriamara@gmail.com.

2 Professor UFMG - Programas de Pós-graduação em História e Educação. Email: beafae.ufmg.br

3 POMIAN, K. Coleção. Enciclopédia Einaudi. Memória/História.Lisboa: Imprensa Casa da Moeda, Volume I, 1982, p.51-86. 
cultivar plantas envolve uma diversidade de elementos que vão de questões sócio-econômicas às afetivo-espirituais. Nessa relação é essencial apreender que, se na natureza as espécies vegetais visam "estabelecer um equilíbrio biológico pela relação mútua das diversidades específicas", para os humanos seu valor envolve a criação de conjuntos harmoniosos e que avocam a atenção. ${ }^{4}$

A circulação de espécies de orquídeas pelo mundo se conecta com as viagens de naturalistas, coletores e colecionadores particulares. De acordo com Pabst, entre o século XVI e a publicação do Sistema Naturae de Lineu as espécies conhecidas passaram de um total de 13 para 62 . 0 lugar ocupado pelas orquídeas brasileiras nesse processo foi gradativo. O fato de existirem coletores no país, a partir do século XIX, não denotava a descrição e estudo imediato das coleções. Diversos profissionais estrangeiros que estiveram no país não tinham interesse específico pelas orquidáceas. ${ }^{5}$

Pode-se dizer que os primeiros especialistas de orquídeas nativas surgiram no Brasil nesse mesmo período. De início os estudos eram avulsos e os botânicos dedicados a família Orchidaceae estrangeiros lotados em instituições nacionais. Entre os brasileiros que realizaram pesquisas sistemáticas estavam Barbosa Rodrigues e F.C. Hoehne. ${ }^{6}$ É possível conjecturar que a demanda por flores ornamentais estava ligada também a profissionais como paisagistas e horticultores que chegaram ao país para a construção de praças publicas. Os serviços de jardinagem eram propagandeados na imprensa local e os profissionais que se fixaram no país, caso de Jean Binot e Charles Pinel, especializaram-se na produção de orquídeas. ${ }^{7}$

Esses dois movimentos, de conhecimento acerca das orquidáceas nos meios científicos e o interesse do público, se conectavam freqüentemente. $O$ mercado em torno das flores adquiriu características cosmopolitas sendo possível, por exemplo, solicitar gratuitamente catálogos de empresas horticultoras européias como a inglesa Sanders (St.

4 HOEHNE, F.C. As orquidáceas do Brasil, seu valor e sábio aproveitamento. Orquídea, junho, 1940, p. 159-160.

5 PABST, G.F.J. \& DUNGS, F. Orchidaceae Brasiliensis. Vol 2. Brüche - Verlag Schmersow, 32 Hildesheim, Germany, 1977, p. 14-15.

6 PABST, G.F.J. \& DUNGS, F. Orchidaceae Brasiliensis. Vol 2. Brüche - Verlag Schmersow, 32 Hildesheim, Germany, 1977. (Edição Bilingue)

7 DOURADO, G. O.M. Belle Époque dos Jardins. Da França ao Brasil do século XIX e início do XX. Tese (Doutorado), Programa de Pós-graduação em Teoria e História da Arquitetura e do Urbanismo, Escola de Engenharia de São Carlos da Universidade de São Paulo, 2008, p.83-122. 
Albans8) e Ltd. e a francesa Vacherot-Lecoufle. Uma breve análise das propagandas veiculadas na Orquídea notamos a ênfase dada a novidade que representavam os híbridos e os seedlings para a orquidofilia no início do século XX.

Essa nova fase, marcada pela ciência laboratorial, deve-se á criação da reprodução assimbiótica pelo fisiologista norte americano Lewis Knudson. Os novos mecanismos de germinação desenvolvidos proporcionaram que as coleções não fossem apenas de espécies naturais coletadas em várias partes do mundo - especialmente países tropicais - mas, que convivessem com exemplares produzidos em laboratório resultantes de cruzamentos híbridos. ${ }^{9}$

Nesse contexto a ideia de fundar uma sociedade de amadores começou a tomar forma. No primeiro número da Rodriguesia (1935), periódico oficial do Jardim Botânico do Rio de Janeiro, o médico Luys de Mendonça apresentou resumidamente os objetivos de uma agremiação ao diretor Campos Porto e argumentou que aquela idéia só "vingaria" com o patrocínio de um "nome de projeção cultural", por isso recorrer à instituição. ${ }^{10}$

A disposição de Campos Porto em acolher a iniciativa de uma sociedade orquidófila se adequava ao perfil da Rodriguesia, considerada um instrumento de "vulgarização". ${ }^{11} \mathrm{O}$ diretor se dispunha, inclusive a divulgar os trabalhos da sociedade enquanto ela não tivesse uma revista própria. A relação de proximidade com o meio científico era um dos atributos mais propagandeados pelos membros da sociedade. Conforme verificamos nos estatutos de sociedades congêneres de outros países esse

8 A Sanders (St.Albans) e Ltd. era a empresa responsável pelos registros de híbridos obtidos em qualquer país. Nos anos de 1901, 1915, 1921, 1946 e 1960 o proprietário Frederick K.Sander publicou listas de híbridos conhecidos. O primeiro híbrido registrado é do ano de 1856 e foi obtido por cruzamento de sementes. Em 1960, ano em que foi lançada Lista Completa da Sanders Orchid Hybrids, a Royal Horticultural Society assumiu o cargo dos registros. Ver: REINIKKA, M; ROMERO, G.A. A History of the Orchid. S.l, Timber Press, Inc., 1995, p.83.

9 FAGUNDES, A.B. Germinação assimbiótica das sementes de orquídeas, Orquídea, março, 1939, p.8590. As orquídeas germinam através de uma relação simbiótica que mantêm com um fungo do gênero Rhizoctonia. O processo assimbiótico de germinação consiste em um "método laboratorial onde sementes germinavam em frascos estéreis contendo agar balanceado com nutrientes químicos, carboidratos e um sistema tampão com ph ácido, sem a presença do fungo simbiótico". Disponível em www.mombu.com. Acessado em 30/05/2008.

10 RODRIGUESIA. Noticiário e atividades várias. Inverno, 1935, p. 91-93.

11 De acordo com Bediaga nos primeiros anos a Rodriguesia era subordinada ao Instituto de Biologia Vegetal, Jardim Botânico e Estação Biológica de Itatiaia. BEDIAGA, B. Os primeiros anos da Rodriguesia - 1935-1938: Em busca de uma nova comunicação científica. Rodriguesia, 56 (87): 2005, p. 01. 
traço não era comum. Ademais, há que se considerar que esforços coletivos de amadores variam ao longo do tempo, principalmente aqueles ligados a atividades de campo, caso da botânica. ${ }^{12}$

O objetivo de Luys de Mendonça foi efetivado em dia 11 de agosto de 1937. Um grupo reunido no Teatro Municipal da cidade de Niterói/RJ fundou a Sociedade Fluminense de Orquídeas. Nos anos subseqüentes houve um boom de criação de sociedades orquidófilas por todo o país e o presidente da sociedade, Luys de Mendonça, passou a editar uma revista de nome Orquídea (1938-1974), destinada a "vulgarizar" ${ }^{13}$ os conhecimentos sobre a vida das orquidáceas, especialmente as brasileiras. A expansão das atividades culminou com a modificação do nome da agremiação, em 1948, para Sociedade Brasileira de Orquidófilos $(\mathrm{SBO})^{14}$. Entre a fundação e os anos seguintes o número de sócios cresceu de forma contínua. O maior número de agremiados se encontrava no Rio de Janeiro, seguidos por São Paulo, Minas Gerais, Espírito Santo, Santa Catarina e Rio Grande do Sul. Na relação de sócios honorários faziam parte os botânicos Alberto Sampaio, Curt Brade, Campos Porto e F.C.Hoehne e Julian Acuña. ${ }^{15}$

No interior do grupo existiam debates acerca do papel da ciência e do mercado na formação do colecionador. Uma das temáticas era a difusão dos híbridos que, para alguns imprimiu uma mudança na educação dos gostos. Os olhares se voltaram para plantas obtidas em laboratório em detrimento das espécies naturais. $O$ aspecto desbravador inerente ao amador, a disposição para a caçada/colheita corria, portanto o risco de ser abandonada futuramente

Atualmente estamos acostumados a ver quase que somente híbridos e assim nunca observamos uma espécie como deveria ser observada. As flores simples, como as gentes simples, devem ser vistas tais quais se apresentam e não devemos exigir delas o que não podem dar. Coletores de planta de todos os tempos ficavam extasiados diante do que viam

12 Recorremos ao regulamento das sociedades européias, em especial a francesa, pois essa era tomada como modelo por outras associações. Société des Orchidofiles Français. Règlement. L'orchidophile, mai, 1891, p.129-132

13 De acordo com Moema Vergara "do século XIX até os anos de 1930, os cientistas e literatos utilizavam regularmente vulgarização". Gradativamente o termo foi caindo em desuso, substituído por divulgação científica. VERGARA, M. de R. Contexto e conceitos: História da Ciência e "vulgarização científica" no Brasil do século XIX. Interciência, v..33, n. 5, p.324-329, mai.2008.

14 Diário Oficial da União, 11 de outubro de 1948, p.53, seção 1.

15 Relação dos sócios da Sociedade Fluminense de Orchideas, Orquídea, setembro, 1939, p.05. 
nas matas e estas orquidáceas que hoje são olhadas com pouco caso, merecem deles, páginas de verdadeiro entusiasmo. Há certas qualidades padrões que podem ser usadas, para determinar a extensão em que o auxílio visual é de valor na apreciação do que se olha. É preciso mais do que ver; é preciso observar. $^{16}$

Outra ideia que circulava era a de que as restrições com os híbridos foram geradas pelo pensamento de grupos ou correntes que cultuavam apenas plantas brasileiras ${ }^{17}$.

O interesse pelas orquidáceas mobilizou igualmente os meios legislativos quando uma lei foi sancionada, pelo então presidente Getúlio Vargas, com a finalidade de regular o comércio das espécies nativas. O texto apresentado na Câmara Federal trazia como justificativa um artigo de autoria de Otto Prazeres publicado no Jornal do Brasil (27 de setembro, 1935). Referindo-se aos ciclos de econômicos do país o autor denominava as orquídeas de "ouros de todas as cores", referia-se às espécies utilizadas com êxito nas hibridações; fornecia estatísticas das espécies encontradas em todas as regiões; reportava-se a importância dos orquidários oficiais e, por fim, alentava para a possibilidade das espécies nativas constarem de forma legal na balança comercial brasileira: "preciso se torna proibir a exportação e difundir no país, de forma nítida, o valor das orquídeas que se prestam, como poucas outras flores, ao comércio floral, não só pela beleza que tem, como pela duração em que nenhuma outra flor consegue superá-las". ${ }^{18}$

Considero a SBO e a Orquídea como indissociáveis, embora a revista não se submetesse juridicamente à sociedade. Formalmente ela pertencia a Luys de Mendonça, que como presidente da agremiação privilegiou sua história. Além disso, existiu um esforço em noticiar todo o movimento orquidófilo brasileiro, do qual o médico era uma espécie de mentor.

A estrutura da revista obedecia à seguinte ordem: na primeira parte os "trabalhos técnicos originais", na segunda "trabalhos de vulgarização, porém, dentro de absoluto rigor científico", na terceira "notas, informações bibliográficas e resumos de revistas". Como já foi dito a orquidofilia

16 GROTA, A. S. Saber ver. Boletim da SBO. Julho, vol.1, n.6, 1958, p. 98-99.

17 WARAS, E. Orquídeas brasileiras no estrangeiro. Orquídea, mar-abr, 1964, p. 96.

18 Sobre a exportação das nossas Orchideas. Orquídea, setembro, 1938, p. 25-27. 
não era pensada como diletantismo, mas na vizinhança da ciência. Os artigos de profissionais apareciam na primeira parte da revista e dos amadores na segunda. As escolhas dos assuntos, dos autores, das imagens eram dos amadores. Sendo assim, cabe indagar se essa divulgação teria algo de específico, se os amadores reinventavam a sua maneira o ato de divulgar a ciência. ${ }^{19}$

A Orquídea permite ver processos pelos quais o conhecimento é reconstituído dentro da cultura. Tanto o amador quanto o profissional erigem discursos nos quais tem a tarefa de disseminar a ciência das orquídeas para o grande público. No entanto, é visível que as práticas dos orquidófilos se constroem no interior de um discurso, o que exige $o$ domínio de uma linguagem própria.

A intenção de estabelecer um vínculo entre amador e profissional partia de algo dado como natural; o periódico como o elo articulador de anseios e projetos. De acordo com Hoehne, a sociedade era formada por amadores, mas "instituída por pensamento científico". 20 Entretanto, ao mesmo tempo em que a aproximação entre amadores e profissionais era valorizada, vários artigos indicam a tensão entre eles. O botânico do Museu Nacional, Alberto Sampaio considerava, por exemplo, que alguns problemas só seriam dominados por especialistas, como no caso de caracteres associados geneticamente nos cruzamentos naturais. Quanto à sistemática se preocupava em não disseminá-la de maneira fragmentada:

deve-se evitar sempre a "meia ciência", tanto mais no caso de sistemática de orquídeas em que se deve ficar apto a reconhecer qualquer gênero, cultivado ou não; apanhada técnica e conhecida bem a organografia, a norma para identificar um gênero é a mesma para qualquer outro ${ }^{21}$

Consideramos que o perfil da maior parte dos artigos visava guiar o iniciante para um grau mais apurado dos conhecimentos sobre as orquidáceas. A percepção de um conjunto de condições favoráveis (luz, ar, calor, umidade) ao cultivo de determinadas espécies se tornavam inteligíveis aos leigos, expondo medidas pragmáticas e recorrendo ao teor

19 Palavras a propósito (editorial), Orquídea, setembro, 1938, p.04.

20 HOEHNE, F. C. Amigos da Flora Brasílica. Orquídea, vol.2, n.1, setembro, 1939, p.05

21 SAMPAIO, A. J. de. Orquídea, vol.1, n.4, junho, 1939, p. 142. SAMPAIO, A. J. de. Iniciação em sistemática de Orquídeas III. Orquídea, vol.2, n.2, dezembro, 1939, p.54. 
afetivo da arte de cultivar, que como diziam "dependia da observação, paciência e amor às orquídeas". Mas também havia a preocupação em fornecer subsídios técnicos próprios de uma especialização. Exemplo disso é o artigo onde a cultura assimbiótica é objeto de discussão, tema que exigia um esclarecimento mínimo de processos reprodutivos, com o sugestivo título "Do jogo do azar para o campo da ciência. Como se faz a cultura assimbiótica". ${ }^{22}$

Ao analisarmos o tipo de divulgação realizado na Orquídea torna-se necessário não uniformizar esses dois momentos - o do profissional e do amador - mas pensar que tipo de mensagem resulta dele. Perceber que nesse intento existe uma pedagogia e que, embora, os grupos possam falar em meios exclusivos de comunicação, o fato de compartilharem um espaço torna-se um problema. Poderíamos, portanto, falar de uma divulgação híbrida, baseada nessa tensão oscilante entre amador e profissional que se configura nas páginas do periódico.

O que dizer, então, dos escritos dos profissionais? A estratégia de trazer cientistas renomados para publicar tem uma dupla função. Vejamos o caso do botânico F.C.Hoehne. O cientista confere autoridade à publicação e também dá ao grupo uma característica estrutural; o de que eles agem e se orientam por fundamentos racionais. Nesse processo o grupo traz para junto de si valores dos cientistas, e, portanto, todo um ideário próprio da ciência. Em alguns artigos - escritos em forma de pequenos cursos - os profissionais deixavam breves recados para os amadores. Alertavam para procedimentos mínimos em uma atividade de campo: produzir imagens das espécies encontradas, descrever o habitat, dentre outros. Sendo assim, os profissionais introduziam sutilmente mecanismos de "decodificação visual" pertencentes ao seu métier.

22 SILVA, W. Do jogo do azar para o campo positivo da ciência. Como se faz a cultura assimbiótica? Orquídea, vol.11, n.5, maio-junho, 1949, p.174. 


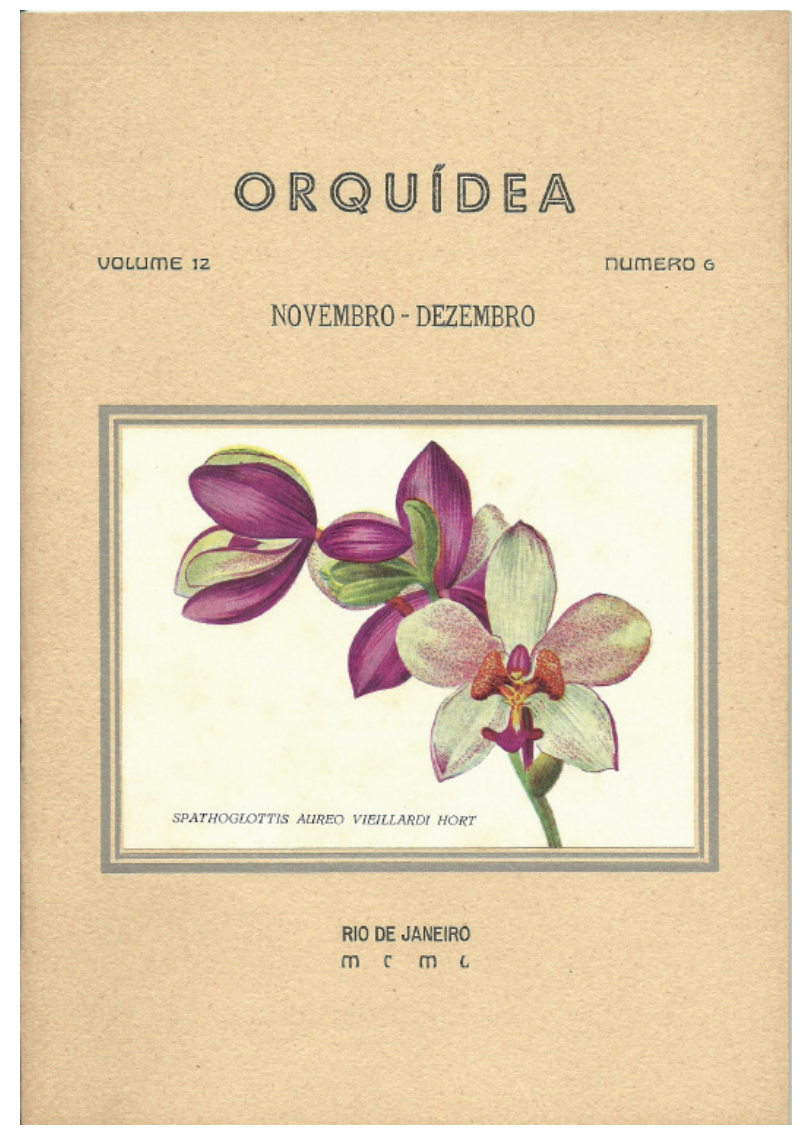

Orquídea, vol.12, n.06, nov-dez, 1950.

Direitos cedidos gentilmente pela atual diretoria da OrquidaRIO

(www.orquidario.org)

As páginas da Orquídea eram recheadas de belas fotos e ilustrações das mais variadas espécies. Esse recurso nos leva para além dos aspectos gráficos, visto que, a ilustração botânica - e posteriormente a fotografia - são uma condição para a prática botânica, ou seja, são constitutivas do fazer científico analisado. Faziam parte da diretoria da $\mathrm{SBO}$ um fotógrafo e um desenhista. Além do trabalho desses membros as ilustrações vinham de afiliados de todo país. Em um dos cursos de sistemática ministrados pelo botânico Alberto Sampaio a importância do desenho era salientava, pois as "orchideas dão em geral más preparações secas, quando preparadas em líquido consevador, suas flores perdem as cores". Segundo o autor, o desenho era a "melhor forma de 
análise e registro de caracteres morfológicos" e, por isso, convidada os orquidófilos iniciados a fazerem croquis de cada planta colhida para a confecção de um fichário iconográfico. ${ }^{23}$

Cada dado recolhido e documentado em uma atividade de campo engendra as vias de uma narração e sua produção. Como constatamos na Orquídea, agrega orquidófilos e cientistas, ou seja, a capacidade de narrar própria do profissional por vezes se combina a de outros atores que contribuem com fragmentos, por vezes esquecidos. ${ }^{24}$

É interessante notar que o histórico da orquidologia por parte dos botânicos é escasso. Isso se deve em parte aos tipos de documentos que os botânicos consideram relevante de serem preservados. As exsicatas $^{25}$ de um herbário talvez sejam mais dignas de preservação. Relatórios de excursões, cadernos de campo, por vezes são abandonados, pois todas essas informações podem ser lidas nos exemplares do herbário, já que uma exsicata não é propriedade de um único botânico, mas passa por outros profissionais que acrescentam informações, fazem revisão da espécie. O botânico lê o histórico de sua ciência por outros documentos. ${ }^{26}$

Alguns orquidófilos transitavam entre as esferas públicas e reivindicavam apoio para sua atividade. O Serviço de Informação Agrícola, por exemplo, financiou a publicação da Orquídea por alguns anos e disponibilizou um funcionário para o Conselho Técnico da agremiação (no biênio 1950-1951 o agrônomo Verlande Duarte Silveira ocupava esse cargo $)^{27}$. Outra solicitação era a instalação de orquidários públicos, cuja função, tinha por propósito irradiar conhecimentos botânicos para a comunidade. Mas o ganho advindo da organização de orquidários conferia igualmente status ao botânico, pois como destacou Hoehne a constituição desses espaços fazia "subir grandemente a nossa cotação como intelectuais na opinião estrangeira". ${ }^{28}$

23 SAMPAIO, A.J.de. Iniciação em Systemática de Orchideas. Orquidea, junho, 1939, p.156-158.

$24 \bigcirc$ estado do Espírito Santo é o que tem maior número de ilustrações feitas por um amador. STENGERS, I. A invenção das ciências modernas. São Paulo: Editora 34, 2002, p.169-171.

25 Exemplar dessecado de uma planta qualquer, conservado em herbários. Dicionário Aurélio, CD-ROM.

26 Ver PACHECO, C.de A. Jardim Botânico do Rio de Janeiro: memória e arquivo. In: MARTINS, R.A.; MARTINS, L.A.P.; SILVA, C.C.; FERREIRA, J.M.H. (Eds.). Filosofia e história da ciência no Cone Sul: 3o Encontro. Campinas: AFHIC, 2004, p.110-114.

27 Sociedade Brasileira de Orquidófilos. Orquídea, mar-abr, 1939, p. 72-73.

28 HOEHNE, F. C. O Brasil e as Orchidaceas. Orquídea, vol.1, n.1, Niterói, 1938, p.11. 
Portanto, acompanhar o histórico de orquidólogos e orquidófilos requer atenção a essas intersecções. Os amadores utilizavam sua proximidade com a poder público para requerer os orquidários e conseqüentemente suas habilidades político-estratégicas influenciavam nos materiais disponíveis para as atividades científicas. Além disso, muitos exemplares provenientes de "caçadas de orquídeas"- como os orquidófilos designavam suas atividades de campo - promovidas pelas sociedades, eram enviados para as instituições.

De acordo com os membros da SBO, o cumprimento de requisitos próprios de uma atividade campo diferenciava os verdadeiros orquidófilos dos colhedores de orquídeas para fins comerciais, que procediam tiradas contínuas e desorganizadas. Contudo, não deixa de causar impacto uma lista de orquídeas colhidas no ano de $1940 \mathrm{em}$ municípios no Rio de Janeiro, contabilizando 7989 touceiras de diversas espécies. A divulgação da colheita em um artigo já mostrava nas primeiras linhas que aqueles homens se atrelavam a um ideal cientifico, pois todo o material seria entregue ao Horto Botânico de Niterói. ${ }^{29}$

Tais planos de cooperação com instituições públicas se mantiveram ao longo dos anos. Em março de 1958 a sociedade promoveu uma campanha de plantas em prol do Jardim Botânico do Rio de Janeiro. A iniciativa foi publicada no recém criado Boletim da $S B O$ onde pudemos verificar a continuidade das relações com o diretor Campos Porto, sempre presente nas reuniões do período. ${ }^{30}$

Ainda no intuito de perceber o mecanismo de construção da divulgação, outras formas de atuação noticiadas no periódico devem ser observadas. Afora os artigos que são o principal meio de análise, ainda constam: excursões, palestras e exposições. Nessas duas últimas circunstâncias o público de forma geral se mistura ao dos orquidófilos iniciados, surge então, um convite à percepção da territorialidade nacional e ao entendimento da botânica como uma espécie de "ciência nacional". Por isso, os atores aqui envolvidos consideram a constituição das coleções, sejam elas privadas ou públicas, uma conduta territorial que corresponde a inferir a natureza, representada pelas orquídeas, como herança. Essa herança dos homens só seria percebida devidamente pela intensificação das atividades de divulgação.

29 O papel das Sociedades de Orquidófilos (editorial). Orquídea, vol.12, n.2, mar - abr, 1950, p. 43. SANTOS LIMA, J. Op cit, p. 65-66.

30 Boletim da SBO. Vol. 1, números 1-6, 1958. 
O comportamento do colecionador extrapola as fronteiras da sua própria coleção, especialmente se eles se associam. $\bigcirc$ grupo ao qual nos dedicamos orientou por décadas um pensamento colecionista voltado para uma botânica de matizes nacionais. A especificidade da Orquídea reside em fazer circular a idéia de colecionismo e conseqüentemente de todo o conflito inerente a constituição das coleções. Cabe ainda dizer que para os membros da SBO as práticas orquidófilas deviam se converter em um processo mais amplo de conservação das matas e criação de parques nacionais. Diversos números da Orquídea traziam o mote "todo bom brasileiro e verdadeiro orquidófilo, deve lutar com todas as suas forças para impedir a devastação criminosa e sistemática das nossas reservas florestais".

A prática da divulgação científica acerca das orquidáceas afirmava, portanto que as contingências históricas não imprimem suas marcas somente nos homens, mas também nas plantas. A história das orquídeas confirmava isso: de portadoras de $a^{2}{ }^{31}$ a objetos de desejo.

31 As orquídeas foram consideradas parasitas durante muito tempo. Nas palavras de Hoehne: "Tudo que escapa da regra sempre impressionou ao homem. Já mostramos também como as nossas belas Orchidaceas, por vegetarem em troncos secos ou ainda sobre as rochas abruptas, foram, durante séculos consideradas portadoras de azar, e todos sabem quão difícil se tornou vencermos na campanha que encetamos, pela imprensa e pela palavra, contra tão absurdo conceito". Palestra proferida por F.C. Hoehne aos Amigos da Flora Brasílica como parte das atividades de divulgação do Instituto de Botânica/SP. HOEHNE, F.C. Da sensibilidade e motilidade dos vegetais. São Paulo: Secretária da Agricultura, Indústria e Comércio, 1945. (Separata do Relatório Anual do Instituto de Botânica referente a 1944) 


\section{Referências bibliográficas}

BEDIAGA, B. Os primeiros anos da Rodriguesia - 1935-1938: Em busca de uma nova comunicação científica. Rodriguesia, 56 (87): 2005, p.1-12.

BEINART, W; MIDLETON, K. Transferências de plantas em uma perspectiva histórica: o estado da discussão. Topoi, v. 10, n. 19, jul.-dez. 2009, p. 160-180.

Boletim da SBO. Vol. 1, números 1-6, 1958.

Como registrar um híbrido? Boletim da SBO, fevereiro, 1958, vol.1, n. 1.

Diário Oficial da União, 11 de outubro de 1948, p.53, seção 1.

DOURADO, G. O.M. Belle Époque dos Jardins. Da França ao Brasil do século XIX e início do XX. Tese (Doutorado), Programa de Pós-graduação em Teoria e História da Arquitetura e do Urbanismo, Escola de Engenharia de São Carlos da Universidade de São Paulo, 2008.

FAGUNDES, A.B. Germinação assimbiótica das sementes de orquídeas, Orquídea, março, 1939, p.85-90.

GROTA, A. S. Saber ver. Boletim da SBO. Julho, vol.1, n.6, 1958.

HOEHNE, F. C. O Brasil e as Orchidaceas. Orquídea, vol.1, n.1, Niterói, 1938.

HOEHNE, F. C. Amigos da Flora Brasílica. Orquídea, vol.2, n.1, setembro, 1939.

HOEHNE, F.C. As orquidáceas do Brasil, seu valor e sábio aproveitamento. Orquidea, junho, 1940.

HOEHNE, F.C. Da sensibilidade e motilidade dos vegetais. São Paulo: Secretária da Agricultura, Indústria e Comércio, 1945. (Separata do Relatório Anual do Instituto de Botânica referente a 1944)

HOEHNE, F.C, KUHLMANN, M, HANDRO, O. O Jardim Botânico de São Paulo. São Paulo: Secretaria da Agricultura, Indústria e Comércio de São Paulo, Departamento de Botânica, 1941. 
HOEHNE, F.C. Da sensibilidade e motilidade dos vegetais. São Paulo: Secretária da Agricultura, Indústria e Comércio, 1945. (Separata do Relatório Anual do Instituto de Botânica referente a 1944)

KUKLIC, H; KOHLER, R. The History of Science Society, Osíris, 2nd séries, 1996, 11, p. 01-14.

LARANJA, J. Orchideas de semente. Orquídea, dezembro, 1938.

PABST, G.F.J. \& DUNGS, F. Orchidaceae Brasiliensis. Vol 2. Brüche - Verlag Schmersow, 32 Hildesheim, Germany, 1977. (Edição Bilingue)

PACHECO, C.de A. Jardim Botânico do Rio de Janeiro: memória e arquivo. In: MARTINS, R.A.; MARTINS, L.A.P.; SILVA, C.C.; FERREIRA, J.M.H. (Eds.). Filosofia e história da ciência no Cone Sul: 3ํㅡㄹ Entro. Campinas: AFHIC, 2004, p.110-114.

Palavras a propósito (editorial), Orquídea, setembro, 1938.

PEREIRA, R. M.A. Ilustração Botânica. Belo Horizonte: PROEX/UFMG, 2008. (Cadernos de Ilustração Científica 2)

POMIAN, K. Coleção. Enciclopédia Einaudi. Memória/História.Lisboa: Imprensa Casa da Moeda, Volume I, 1982, p.51-86.

REINIKKA, M; ROMERO, G.A. A History of the Orchid. S.l, Timber Press, Inc., 1995.

Relação dos sócios da Sociedade Fluminense de Orchideas, Orquídea, setembro, 1939.

RODRIGUESIA. Noticiário e atividades várias. Inverno, 1935.

SÁ, D.M. de. A Ciência como profissão: médicos, bacharéis e cientistas no Brasil (1995-1935). Rio de Janeiro: Editora Fiocruz, 2006.

SAMPAIO, A.J.de. Iniciação em Systemática de Orchideas. Orquídea, junho, 1939

SAMPAIO, A. J. de. Iniciação em Systemática de Orquídeas III. Orquídea, vol.2, n.2, dezembro, 1939. 
SILVA, W. Do jogo do azar para o campo positivo da ciência. Como se faz a cultura assimbiótica? Orquídea, vol.11, n.5, maio-junho, 1949.

Sobre a exportação das nossas Orchideas. Orquídea, setembro, 1938.

Sociedade Brasileira de Orquidófilos. Orquídea, mar-abr, 1939.

Société des Orchidofiles Français. Règlement. L'orchidophile, mai, 1891, p.129-132.

STENGERS, I. A invenção das ciências modernas. São Paulo: Editora 34, 2002.

VERGARA, M. de R. Contexto e conceitos: História da Ciência e "vulgarização científica" no Brasil do século XIX. Interciência, maio 2008, vol.33, no 5 , p. 324-330.

WARAS, E. Orquídeas brasileiras no estrangeiro. Orquídea, mar-abr, 1964, p. 91-98. 
15.

\title{
A Química no Melhoramento da Produção Agrícola e sua Divulgação na Revista Agrícola
}

\author{
Bruno Capilé ${ }^{1}$ \\ Nadja Paraense dos Santos ${ }^{2}$
}

O desenvolvimento de inovações tecnológicas e científicas, no século XIX, fomentou o surgimento de áreas especificamente voltadas para a agricultura. Como, por exemplo, as disciplinas de fisiologia vegetal e parasitologia entomológica, que forneceram conhecimentos sobre a vida vegetal e os males que lhes afligiam. Porém, o despontar da agricultura somente foi reivindicado com o reconhecimento da importância dos nutrientes do solo no desenvolvimento vegetal, que pode ser demonstrado com a aplicação da química agrícola em técnicas de restituição de solo.

Esses conhecimentos não tinham o alcance necessário para promover mudanças nas concepções de manejo do solo em grande parte do território brasileiro, possivelmente limitado pela ideologia agro-industrial vigente, um paradigma de estagnação cultural, científica, industrial, e principalmente, agrícola. É nesse mesmo momento histórico que os métodos utilizados na produção agrícola começam a entrar em grande conflito com as conseqüências econômicas e ambientais. Com o devido reconhecimento desses, e outros problemas, o governo imperial toma a iniciativa de criar entidades voltadas para o melhoramento da agricultura além do Ministério da Agricultura, do Comércio, e das Obras Públicas, e os Institutos Agrícolas na década de 1860 (CAPILÉ, 2010).

\footnotetext{
1 Mestre em História das Ciências e das Técnicas e Epistemologia (HCTE/ UFRJ) e bolsista PCI do Museu de Astronomia e Ciências Afins (MAST/MCT)

2 Pesquisadora e Professora do HCTE/UFRJ
} 
Dentre os institutos criados ${ }^{3}$, destaca-se a entidade situada na Corte, o Imperial Instituto Fluminense de Agricultura (IIFA), criado a partir do Decreto n 2607 de 30 de Junho de 1860, "para animar e desenvolver a agricultura". O IIFA tomava para si os conhecimentos técnicos e científicos úteis à lavoura, e desenvolvia meios para aplicá-los nas atividades da Fazenda Normal, do Laboratório Químico e principalmente através da publicação dos artigos de seu periódico, a Revista Agrícola (18691891)4. A partir dos artigos sobre química agrícola é possível analisar se a revista contemplou sua proposta de vulgarização do conhecimento científico e técnico necessário para um leitor leigo compreender, e aplicar na agricultura.

\title{
Entre derrubadas e queimadas... $O$ enfraquecimento das terras
}

\begin{abstract}
O que tem sido na verdade até hoje a agricultura no Brasil? Uma profissão aparentemente ingrata e mal definida (...). Nós a temos visto marchar às tontas entre o acaso e o empirismo, trazendo por divisa um tríplice aniquilamento - a devastação de matas, a calcinação do solo, o enfraquecimento das terras (NETTO, 1870, p. 5).
\end{abstract}

O aniquilamento citado por Ladislau de Souza Mello Netto (18381894), último redator da Revista, foi a culminância de anos de estratégias irresponsáveis de manejo do solo. Existe a possibilidade desse modo de utilizar a terra ser interpretado como uma política de ocupação territorial de um Brasil que ainda está para ser descoberto. Ou seja, tal política de uso extensivo do solo teria uma importância para reivindicar a posse da terra para o império brasileiro. De qualquer forma, a falta de conhecimento de técnicas e ferramentas básicas da lavoura dos trabalhadores rurais ocasionou um grande desgaste do solo da lavoura brasileira, resultante das constantes queimadas e derrubadas ${ }^{5}$. Esse comportamento era

3 Os institutos agrícolas surgiram após a viagem do Imperador Dom Pedro II ao Nordeste que iniciou em 01 de outubro de 1859 partindo do Rio de Janeiro, e termina em 11 de fevereiro de 1860, passando pelas províncias da Bahia, Pernambuco, Paraíba, Alagoas, Sergipe e, na volta, pelo Espírito Santo.

4 A Revista Agrícola foi toda digitalizada da Seção de Obras Raras da Biblioteca do Jardim Botânico do Rio de Janeiro, e está disponibilizada no site http://raiifa.4shared.com. A pesquisa resultou também em uma dissertação de mestrado (CAPILÉ, 2010).

5 Para mais informação sobre a história da degradação ambiental no Brasil, ver PÁDUA (2004). 
criticado na época, em relatório do Ministério da Agricultura ${ }^{6}$ de 1863, o ministro Domiciano Ribeiro escreve convenientemente que "o lavrador entre nós é um nômade, que hoje cria e destrói aqui, para amanhã criar e destruir acolá", e ressalta que enquanto não soubermos aproveitar o solo "nem a propriedade terá 'fixidade', nem o país verdadeira civilização" (BRASIL, 1864, p. 4).

Através desse discurso inicial, podemos observar que existe um paradoxo de ocupação do solo. De um lado temos a ocupação irresponsável do solo que se assemelha às atividades exploratórias do Brasil colonial, o que garante um domínio extenso do território. Essa índole acaba por gerar lacunas de desenvolvimento ao longo dessa ocupação, pois à medida que novas fazendas eram estabelecidas, as antigas já não se prontificavam como pólos de produção agrícola eficientes. O que acaba por limitar os meios de transporte para o escoamento dos produtos pela distância. Do outro lado, temos uma iniciativa de ocupação que visa regenerar o solo que permite a permanência da atividade agrícola virtualmente por tempo indeterminado. Desse modo, os meios de transporte, e o desenvolvimento decorrente, poderiam acompanhar em um ritmo firme e constante, sem gerar as citadas lacunas.

Justus Von Liebig (1803-1873), em artigo transcrito na Revista Agrícola, afirmava que a nação que deixava o solo empobrecer gradualmente ao longo dos anos sem administrar meios de impedir, iria falecer por inanição ou buscar novos terrenos férteis (LIEBIG, 1875). Para isso eram necessários meios técnicos que possibilitassem a regeneração dos nutrientes do solo desgastado. Veremos adiante como a técnica se desenvolveu e como a Revista Agrícola difundiu esses conhecimentos em seus artigos.

\section{Novas ideias e paradigmas: a ascensão da química agrícola}

No século XIX a química agrícola encontra terreno e se desenvolve plenamente como uma ciência própria. Para contextualizar o trabalho, resumiremos a história em três momentos apenas: a unificação da química inorgânica com a química orgânica e as obras de Humphry Davy (1778-1829) e Liebig. Ambos os autores não estiveram sozinhos, algumas pesquisas anteriores ajudaram na evolução do pensamento e

6 Relatório do Ministério da Agricultura (1864). 
desenvolvimento de técnicas, como as de Joseph Priestley (1733-1804), Joseph Black (1728-1799) e de Carl Scheele (1742-1786) que no auge do Iluminismo realizaram pesquisas para a determinação da composição do ar atmosférico, assim como dos elementos que constituem as plantas.

O trabalho de Davy culmina com a publicação de Elements of Agriculture Chemistry In a Course of Lectures (1813) como resultado dos esforços do governo britânico e das sociedades científicas para buscar soluções para melhores lavouras. Embora tenha sido contratado para resolver problemas de cunho técnico, Davy elaborou uma teoria para explicar a nutrição vegetal a partir do húmus, considerado por ele como a única substância assimilável pela planta ${ }^{7}$, relegando os elementos minerais a função de estimular a matéria orgânica contida no húmus. Isso encorajou a importação de guano ${ }^{8}$ do Chile e Peru pela Inglaterra, assim como uma corrida em pesquisas e investimentos em fertilizantes por toda a Europa, com especial destaque para Inglaterra, França e Alemanha (BENSAUDE-VINCENT \& STENGERS, 1996).

Mesmo que Davy tenha desenvolvido técnicas que foram comercialmente úteis à lavoura, algumas limitações permaneciam no domínio da química enquanto ciência. Uma de suas principais barreiras epistemológicas, que persistiu até o início do século XIX, era a separação completa entre as áreas da química orgânica e inorgânica, a qual aparentemente não possuía relação direta. A desmistificação teve início com os trabalhos de Friedrich Wöhler (1800-1882) que conseguiu sintetizar um composto orgânico (amônia) a partir de um composto inorgânico (cianato de amônia), e ganhou peso e reconhecimento com os trabalhos de Adolf Kolbe (1818-1884) e Marcelin Berthelot (1827-1907) que também sintetizaram compostos orgânicos através de compostos inorgânicos (RIVAL, 1997).

Somente a partir dessa primeira mudança de paradigma foi possível o desenvolvimento de uma revolução agrícola. E, com os trabalhos de

7 A teoria do húmus, originalmente proposta por Albrecht Daniel Thaer (1752-1828), considera que as plantas são sustentadas por água e húmus absorvidos pelas raízes em desenvolvimento. Apesar da teoria da fixação de carbono por meio da fotossíntese já ter sido desenvolvida, a teoria húmica permaneceu presente até os trabalhos de Nicolas Theodore de Saussure (1767-1845) e Hermann Johann Philipp Sprengel (1834-1906). Saussure realizou experimentos com o crescimento de plantas em areia regadas pela chuva, que continha os sais necessários. Sprengel seguiu o método de Liebig e concluiu que o valor de húmus residia nos minerais que o compõe, principalmente o carbono (mais de 60\%) (BROCK, 1997).

8 O guano se trata de um adubo rico em fosfato e nitrogênio, proveniente de excrementos de aves, morcegos, ou fabricado com resíduos de peixes. 
Liebig $^{9}$ o foco da agricultura torna-se primordialmente o solo, ou seja, o cuidado do solo permite que a planta tenha condições de se cuidar. Liebig é considerado como o principal escritor sobre química agrícola devido à abrangência mundial de sua obra principal, Tratado de Química aplicado à Agricultura, (1840) que foi rapidamente traduzida para o francês, inglês, russo, polonês, alemão, dinamarquês e sueco. A teorização de Liebig baseava-se na Lei do Mínimo e na Teoria Mineral da Nutrição Vegetal. A Lei do Mínimo foi enunciada por Liebig em 1840 e afirmava que 0 crescimento vegetal não pode ser maior que a proporção adequada dos nutrientes essenciais presentes no solo. A Teoria Mineral da Nutrição Vegetal (1862) consistia na absorção mineral pelas raízes das plantas, e na incorporação do carbono do ar atmosférico (BROCK, 1997).

Interessante notar que esses conhecimentos estão presentes nos artigos da Revista Agrícola, como por exemplo, a descrição do momento de controvérsia sobre a importância do nitrogênio encontrada em dois grupos de pesquisadores denominados de Azotistas e de Mineralistas. Os Azotistas atribuíam ao nitrogênio a função principal da nutrição vegetal, sendo o solo um apoio e os minerais, estimuladores. Em contrapartida, para os Mineralistas, seguidores de Liebig, o nitrogênio tinha um papel secundário enquanto que o solo era o principal alimentador (MOREIRA, 1880). Anos depois esse momento histórico é narrado em outro artigo da Revista de uma forma diferente.

Liebig, em 1842, declarava que o azoto acha-se sempre em quantidade suficiente no solo, e que a cultura não o pode esgotar; que a fertilidade de um terreno depende unicamente dos elementos minerais, em caso algum dos azotados. Boussingault combateu estas ideias; estabeleceu o papel preponderante do azoto que, na sua opinião, deve servir para dar a medida da atividade dos estrumes. M. M. Lawes e Gilbert apoiaram essa opinião em experiências diretas, e, após numerosas controvérsias, Liebig, em 1860 abandonou suas ideias demasiado absolutas (REVISTA AGRÍCOLA, 1889, p. 51).

9 Liebig foi bastante influenciado pelo químico Jean-Baptiste Boussingault (1802-1887) que executou trabalhos sobre o teor de nitrogênio em diferentes plantas e a afirmava que o valor de um fertilizante é proporcional ao seu teor de nitrogênio. Curiosamente, Boussingault influenciou a escola de pensamento dos Azotistas, que era antagônica a de Liebig (BROCK, 1997). 


\section{Um novo começo, uma nova revista}

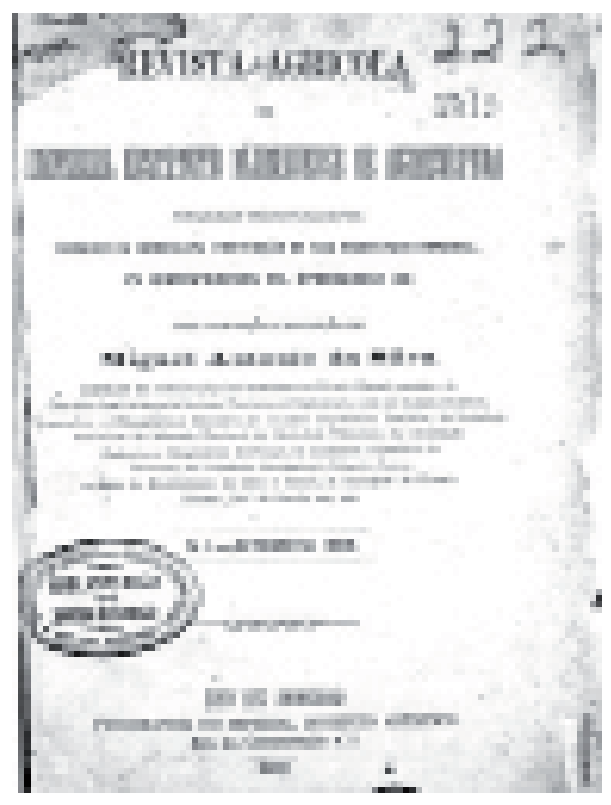

Figura 1- primeira Capa (1869)

A Revista Agrícola surge entre os debates científicos sobre o aparecimento de pragas que atacavam a cana e o café, o empobrecimento do solo e a necessidade de fertilizantes; assim como entre os debates políticos sobre a necessidade de mão-de-obra e a consequente qualificação da mesma para o trabalho na lavoura, e a prioridade na modernização do campo com máquinas agrícolas e transportes ferroviários. A química era apenas uma das vertentes desse periódico que durou 22 anos publicando 90 números com uma média de 55 páginas.

A Revista passou por três momentos históricos que foram profundamente influenciados pelos respectivos redatores. A primeira fase (1869-1879), tendo como redator Miguel Antonio da Silva (1832-1879), marcou-se pela preocupação com a divulgação do conhecimento técnico-científico sobre química agrícola com a predominância de artigos sobre análises do caldo de diferentes variedades de cana-de-açúcar e da descrição de alguns instrumentos voltados para o cultivo da cana, como: um aparelho que condensa o caldo em uma substância concreta e um sacarímetro polarizador de Mitscherlich. 
A segunda fase (1879-1887), da redação de Nicolau Joaquim Moreira (1824-1894), manteve o âmbito de divulgação científica, dessa vez incluindo os conhecimentos de química em que ele mesmo preparara em suas aulas no Museu Nacional, além de aumentar o número de artigos traduzidos e adaptados. A última fase (1887-1891) de Ladislau Netto, diretor do Museu Nacional, manteve a crescente divulgação de conhecimentos científicos. Mas, o padrão observado nessa fase foi a diminuição drástica da publicação de artigos sobre química agrícola. Dentre as diferentes redações da Revista podemos observar que os dois primeiros redatores se concentraram na divulgação de conhecimentos sobre química. De um modo geral, existe uma progressiva especialização da linguagem utilizada. Martins (1995) aponta que ao longo dos anos houve uma redução de sócios fazendeiros, ocorrendo uma "saída maciça". Em contrapartida, ocorreu o aumento do número de intelectuais. Talvez essa especialização possa ser explicada por essa inversão, mas o que importa é que a integração dos saberes científicos nos textos da Revista Agrícola reflete o crescente processo de profissionalização da ciência no país.

\section{A química agrícola na Revista}

A principal divulgação técnico-científica da Revista Agrícola foram as análises químicas de solos e vegetais. As informações químicas sobre o solo e as cinzas vegetais forneciam conhecimentos de que modo os lavradores iriam recompensar o terreno de acordo com a necessidade vegetal. Interpretado à luz dos conceitos de Liebig, os diversos tipos de solos deveriam ser restituídos com estrumes específicos, de modo a otimizar o uso desses. Nos artigos cuja autoria se pode identificar como sendo dos químicos responsáveis ${ }^{10}$ pelo Laboratório Químico do IIFA, destacam-se as análises que enfatizavam a produção açucareira, em períodos distintos, como decorrência das pragas que afetaram a produção (Bahia, 1866 e Pernambuco, 1882). O IIFA que já vinha exercendo pesquisas de campo e de análises químicas, através das comissões e do Laboratório, acumulou grande quantidade de dados que foram divulgados pela Revista Agrícola.

10 Em 1868 inicia as análises químicas no Laboratório Químico do IIFA por Alois Krauss, as mesmas foram publicadas no primeiro número da Revista Agrícola em setembro de 1869. Krauss foi substituído em 1873 por Daniel Henninger após reforma do Laboratório. O último químico a atuar no IIFA, Otto Linger, permaneceu no cargo de 1880 a 1889. As análises realizadas no Laboratório Químico eram provenientes de ordens do Ministério da Agricultura ou de iniciativa do IIFA. Na Revista Agrícola pode-se contabilizar 17 artigos de autoria dos químicos do IIFA. 
Além da restituição do solo através de fertilizantes, havia uma crescente compreensão das propriedades da cana como a relação da proporção de sílica e a resistência às moendas. As análises do caldo e do açúcar extraído visavam fornecer dados para o produtor adequar seu produto frente à demanda do mercado, oferecendo maiores concentrações do caldo e gerando açúcares mais puros e em maior quantidade (KRAUSS, 1869). Podemos observar isso em um artigo sobre fabricação de açúcar, extraído de um periódico inglês, que descreve as diferentes concepções que existiam sobre o açúcar e o caldo, que era considerado como uma substância feita apenas de água e açúcar. O autor relata que o caldo possui diversas substâncias minerais (potassa, soda, cal, óxido de ferro, sílica, etc.), albumina e dois tipos de açúcar, o cristalizável (glicose) e o incristalizável (frutose), que está relacionado com a acidificação do caldo. Nesse artigo explicava os meios de quantificar os diferentes tipos de açúcar através de exame óptico com o sacarômetro e análises químicas com um reativo formado por uma solução de óxido de cobre numa solução concentrada de soda cáustica (ICERY, 1870).

Entre os anos de 1884 e 1887, publicou-se 13 artigos (num total de 70 páginas) sobre as diversas análises químicas realizadas pelo Laboratório do IIFA. Exemplificaremos algumas análises apenas para ilustrar a diversidade da atividade do Laboratório, como: cinzas de Jaqueira, Araucária, Pau-Ferro, Pau de Jangadeira, Jabuticabeira, trigo, cevada, aveia, etc.; semente de algodoeiro, terra em que se cultivaram diferentes tipos de cana, tipos de águas, frutos, etc. Nessas análises informavam a presença e quantidade de diferentes substâncias químicas, como: água; sílica; ácidos carbônico, sulfúrico, fosfórico; fosfato de ferro; óxidos de cálcio, de magnésio, de alumínio, de ferro; etc. O processo de obter as cinzas para realizar as análises foi assim descrito:

Para obter este resultado, começa-se por secar convenientemente as plantas, submetendo-as a uma temperatura de $110^{\circ} \mathrm{C}$ pouco mais ou menos; operase depois a combustão em um pequeno forno, ordinariamente cilíndrico, aquecendo em um grau de calor assaz elevado para fazer desaparecer todo o carbono, obtém-se então as cinzas que representam as substâncias minerais extraídas do solo. (...) Estas cinzas, cuja composição e quantidade variam para cada espécie de planta, são então tratadas pela água que dissolve alguns dos sais e deixa outros no estado insolúvel; a análise química aplicada à estas duas partes (...) indica as substâncias que faziam parte das cinzas (REVISTA AGRÍCOLA, 1871, p. 11) 
A restituição do solo se inicia com o conhecimento do próprio solo, através da caracterização da proporção de argila, areia e calcário, quantidade de umidade, e análise química posterior, "por meio da água forte (ácido nítrico), ou de ácido clorídrico. Se forem calcáreos, se dissolverão com efervescência nestes ácidos" (SILVA, 1869, p. 28). Porém a restituição propriamente dita não se apresentava como um consenso nos diferentes artigos, alguns articulavam o uso exclusivo de fertilizantes químicos; enquanto que outros achavam melhor o uso equilibrado de diferentes adubos, fazendo ressurgir teorias húmicas como a de Davy. Quando a fertilidade consistia no húmus, "a riqueza orgânica do solo é fundamentalmente assegurada", mas se usarmos de forma desmesurada os adubos químicos em uma terra pobre em húmus, teríamos "uma colheita abundante, mas seria isso de algum modo, o último e supremo esforço da terra" (LECOUTEUX, 1875, p. 127).

A Revista não era desprovida de fins didáticos, os artigos técnicos eram complementados por artigos de divulgação de conhecimentos científicos, como os artigos mais descritivos de Miguel da Silva, e as preleções de química de Nicolau Moreira sobre hidrogênio (1881), oxigênio (1881), potassa (1882), cálcio (1882), azoto (1882), soda (1883), entre outros. Dessa forma o leitor poderia aplicar tais conhecimentos científicos e técnicos de química nas diferentes aplicações abordadas pelo periódico.

\section{Conclusões}

De um modo geral, a divulgação dos artigos da Revista Agrícola indicava que os redatores enfatizavam a desmistificação do paradigma de fertilidade vitalícia dos solos, através de artigos de regeneração do mesmo pelo uso da mecânica agrícola, de fertilizantes e de análises químicas e plantas, visando a melhor maneira de restitui-lo. Dessa forma, incentivava também a queda do mito da produtividade abundante, pois os imensos latifúndios de café e cana não podiam se manter sem as ideias de regeneração, e sem o uso de técnicas de melhoramento de espécies, como a fecundação artificial. As diferentes redações da Revista não se preocupavam com a construção de uma imagem de ciência desinteressada, seu interesse principal residia na divulgação das técnicas. A divulgação científica na Revista Agrícola tinha um viés utilitarista dos conceitos difundidos, que, indiretamente, eram voltados para complementar as informações indispensáveis no uso das técnicas agrícolas. 
Através dos dois principais focos da Revista, a restituição do solo e a melhora da produção açucareira, se pode inferir os interesses que moldavam a publicação desses conhecimentos. O primeiro reflete uma política que incentivava a permanência na terra, privilegiando diferentes grupos como os pequenos proprietários e os latifundiários. De qualquer forma, esse tipo de divulgação permitia que os meios de transporte, como as estradas de ferro, escoassem os produtos agrários com mais eficiência. O segundo ponto, a melhora da produção açucareira, pode ser considerado como a manutenção das relações de poder dos grandes produtores de açúcar no Rio de Janeiro e no Nordeste. O que se complementava com as comissões científicas formadas para investigar a ocorrência de pragas nesses locais.

De qualquer forma, vimos que a Revista Agrícola se prontificou como um periódico técnico-científico que estava atualizado com os conhecimentos de sua época. Sua missão era divulgar, buscando explicar de forma didática os métodos a serem utilizados na lavoura brasileira. A química agrícola participou de um movimento de crescente cientifização da produção agro-industrial. $O$ que proporcionou uma alavanca para modificações administrativas como a criação de instituições de ensino e pesquisa voltadas para esses conhecimentos, inviabilizando a continuação do uso de mão de obra escrava na lavoura. Porém, a divulgação de artigos que propiciavam a permanência de latifundiários de cana e café, e o particular carinho que o Imperador Dom Pedro II teve com o IIFA, sujeitaram o Instituto a um crescente abandono após a Proclamação da República. Culminando também com o fim do periódico em 1891. 


\section{Bibliografia}

BENSAUDE-VINCENT, Bernadette; STENGERS, Isabelle. A History of Chemistry. Harvard University Press, 1996.

BRASIL. Relatório apresentado à Assembléia Geral Legislativa na Segunda Sessão da Décima Segunda Legislatura pelo Ministro e Secretário de Estado dos Negócios da Agricultura, Commercio, e Obras Públicas Domiciano Leite Ribeiro. Rio de Janeiro: Typographia Paula Brito, 1864.

BROCK, William. Justus von Liebig: The Chemical Gatekeeper. Cambridge University Press, 1997.

CAPILÉ, Bruno. A Mais Santa das Causas: a Revista Agrícola do Imperial Instituto Fluminense de Agricultura (1869-1891). Dissertação de Mestrado em História das Ciências das Técnicas e Epistemologia do Instituto de Química da Universidade Federal do Rio de Janeiro (HCTE/UFRJ), Rio de Janeiro 2010.

ICERY, Edmond. Fabricação do açúcar. Investigação sobre o caldo da cana e das modificações por que passa durante o fabrico do açúcar na ilha Maurícia. RAIIFA, v. 1, n. 2, p. 6-30, 1870.

KRAUSS, Alois. Cultura da Canna de Assucar: Analyses das Cinzas do Caldo de Canna de Assucar de Differentes Qualidades. RAIIFA, v. 1, n. 1, p. 10-14, 1869.

LECOUTEUX, E. O Humus, os Estrumes Vegetais e os Adubos Chimicos. RAIIFA, v. 6, n. 3, p. 126-131, 1875.

LIEBIG, Justus Von. A Agricultura e a História. RAIIFA, v. 6, n. 2, p. 67-80, 1875.

MARTINS, Maria Fernanda Vieira. O Imperial Instituto Fluminense de Agricultura: Elites, política e reforma agrícola (1860-1897). Dissertação de Mestrado em História do Curso de Pós-Graduação em História da Universidade Federal Fluminense, Niterói, 1995.

MOREIRA, Nicolau Joaquim. Prefacio. In: ZALUAR, A.E. Elementos de Chimica e Physica Agricolas. RAIIFA. v. 15, n. 1, p. 3-4, 1884. 
NETTO, Ladislau de Sousa Mello. Investigações sobre a cultura e a moléstia da cana-de-açúcar. RAIIFA, v. 2, n. 3, p. 3-7, 1870.

PÁDUA, José Augusto. Um Sopro de Destruição: Pensamento Político e Crítica Ambiental no Brasil Escravista (1786-1888). Rio de Janeiro: Jorge Zahar Editora, 2004.

REVISTA AGRÍCOLA. Chimica Agricola: Influência do Solo sobre a Vegetação. RAIIFA, v. 2, n. 6, p. 10-26, 1871.

Associações a que é remetida a Revista Agrícola. RAIIFA, v. 19, n. 2, p. 101-120, 1888.

Nutrição das Plantas. RAIIFA. v. 20, n. 3, p. 41-53, 1889.

RIVAL, Michel. Os Grandes Experimentos Científicos. Rio de Janeiro: Jorge Zahar Editora, 1997.

SILVA, Miguel Antonio da. Do Solo Agrícola. RAIIFA, v. 1, n .1, p. 25-41, 1869 


\title{
Estrangeiros na criação da Escola Agrícola da Bahia (1863-1877)
}

\author{
Nilton de Almeida Araújo ${ }^{1}$
}

\begin{abstract}
O Imperial Instituto Baiano de Agricultura (IIBA), associação de classe integrada por grande proprietários, negociantes e ex-traficantes de escravos, foi criado em 1859 por remanescentes da Sociedade de Agricultura, Comércio e Indústria da Província da Bahia (1832-1836), e pelo governo imperial. Criadas em diferentes contextos, ambas associações tinham como leitmotiv a difusão de conhecimentos agronômicos para restauração e expansão da agricultura baiana. Ambas tinham na criação de uma escola agrícola a principal estratégia para viabilizar a regeneração científica da produção rural. Ambas tinham como membros e diretores elementos com um perfil social e geográfico bastante similar, a partir do Recôncavo Baiano, região produtora de açúcar (ARAÚJO, 2010).

A Escola Agrícola da Bahia (EAB), fundada em São Francisco do Conde, no coração do Recôncavo da Bahia, foi pioneira na diplomação de engenheiros agrônomos no Brasil. Os diretores do IIBA se empenharam em trazer professores europeus para instalar e fazer funcionar aquela escola. A presença européia no corpo docente da EAB costuma ser um dos principais aspectos destacados na bibliografia acerca da instituição (TOURINHO, 1982; CAPDEVILLE, 1991; DOMINGUES, 1995; BAIARDI, 2001; OLIVER, 2005). A proposta deste texto é dar contornos mais nítidos à participação dos estrangeiros no estabelecimento da escola do Imperial Instituto.

primeiro vice-presidente do IIBA, Francisco Golçaves Martins (1807-1872), então barão de São Lourenço, foi um dos primeiros a buscar
\end{abstract}

1 Universidade Federal do Vale do São Francisco - (Prof. Adjunto de História do Brasil - Colegiado de Ciências Sociais).

E-mail: nilton.almeida@univasf.edu.br, nilton.almeida@pq.cnpq.br 
e levar ao conhecimento da Diretoria do IIBA, entre março e julho de 1861, informações obtidas em Paris acerca do engajamento de professores franceses para a criação da Escola de Agricultura.

Um dos primeiros movimentos do IIBA para a composição de seu corpo docente foi a contratação de professores da Escola Agrícola de Grignon, na França, mas não houve êxito nestas negociações (IIBA, Livro de Pareceres, 22/06/1861). As obras de construção da Escola e montagem dos laboratórios duraram de 1863 a 1876. Para dirigir os trabalhos, o primeiro contratado pelo IIBA foi o naturalista francês Louis Jacques Brunet.

Os eixos fundamentais do currículo proposto por Brunet eram a Matemática, a Química, a Engenharia, a Meteorologia e a História Natural conforme podemos identificar abaixo:

$$
\begin{aligned}
& \text { 1. - ano. Matemática. Aritmética. } \\
& \text { 2. ano. Geometria. } \\
& \text { 3. ano. Álgebra. } \\
& \text { 4. ano. Geometria analítica. } \\
& \text { 1. ano. Química elementar. } \\
& \text { 2. ano. Análise química. } \\
& \text { 3.- ano. Química agrícola. } \\
& \text { 4. - ano. Química industrial. }
\end{aligned}
$$

Meteorologia

1. ${ }^{\circ}$ ano. Construções rurais.

2. ano. Drenagem e irrigação.

3. ano. Mecânica rural.

4. ${ }^{\circ}$ ano. Descrição das máquinas e instrumentos agrícolas e suas aplicações.

1. ${ }^{\circ}$ ano. Elementos de história natural.

2. ano. Fisiologia e Física Vegetal.

3. - ano. História das plantas usuais e das plantas cultivadas já introduzidas no Brasil ou que poderiam ser introduzidas.

4. ${ }^{\circ}$ ano. Sericicultura, apicultura, cochonicultura e piscicultura.

(ROSADO, SILVA, 1973: 313) 
Este corpo de disciplinas previa a existência de dez professores, com cada dia letivo composto de três lições de duas horas cada de 3 professores diferentes durante toda a duração (ROSADO, ibidem)

Em 1872, a organização da escola da escola foi dividida em três sessões para acelerar os trabalhos, a cargo de Louis Jacques Brunet e os naturalistas Luis Moreau e Frederico Maurício Draenert. Mas quem foram estes europeus que deram as primeiras coordenadas para a escola da Bahia? E como foram eles engajados na Escola Agrícola?

Brunet nasceu em Moulins (França), em 1811, e antes de mudar para o Brasil fora professor de História Natural e Música de Bazas (1835). Chegando a Pernambuco em 1850, tornou-se professor do Ginásio Pernambucano em 1855, tendo sido exonerado em dezembro de 1863, para trabalhar nas obras de construção da Escola em São Francisco do Conde (ROSADO, SILVA, 1973: 23, 42, 305).

Antes de trabalhar para o IIBA, Brunet foi um dos naturalistas viajantes que municiou as coleções de rochas e minerais do Museu Nacional, destacando-se uma viagem à Amazônia entre junho de 1860 e final de 1861, tendo remetido inúmeras vezes produtos naturais do Pará (LOPES, 1997: 98-99 e 113). Brunet também mantinha conexões com instituições européias como a Société d'Aclimatation de Paris, que em 1874 conferiu ao naturalista uma medalha².

O catálogo da Biblioteca de Brunet enfatiza tanto uma ligação com as atividades científicas brasileiras como: Relatório acerca dos Jardins Botânicos de J. Monteiro Caminhoá (1874); várias edições dos Archivos do Museu Nacional do Rio de Janeiro, desde o primeiro número (1876); os Estudos sobre a quarta exposição nacional de 1875, de José Saldanha da Gama; diversos livros da Associação Brasileira de Aclimação (inclusive os Estatutos); Contribuição ao estudo da Geologia do Brasil de Orville Derby (1882), e em especial o Catálogo da Biblioteca da Escola Agrícola de São Bento das Lages (1875) composto por Frederico Draenert (ROSADO, SILVA, 1973: 46-56).

2 "Grisard Jules, agente geral da Sociedade, escreveu-lhe a 27/10/1874: 'M. Geoffroy Saint-Hilaire informa-me que a medalha que vos foi conferida pela Sociedade de Aclimatação não vos é ainda... Venho de informar-me sobre o assunto na Embaixada do Brasil; foi-me respondido que a medalha tinha sido enviada e que poderíeis reclama-la no Ministério dos Negócios Exteriores no Rio - Janeiro (sic). Saberia com prazer, Senhor, que obtivestes a entrega de vossa recompensa. Aceitai, Senhor, a certeza de minha consideração mais distinta". (ROSADO, SILVA, 1973: 310-311). 
Entre os 186 livros mapeados por ROSADO e SILVA, destacam-se os de idioma francês como Histoire Naturelle des Poissons ou Ichthyologie genérale de Auguste Duméril, Societé D'Apiculture de La Gironde (1875), La Colonie Suisse de Nova Friburgo et la Société Philantropique Suisse de Rio de Janeiro (1877), Cataloque raisonné du Museé des écoles (1885), Dictionnaire Pittoresque D'Histoire Naturelle et des Phenomènes de la Nature (1835, 5 vol.) ou Rapport présenté au non du Conseil D'Administration (1872) de Geoffroy Saint-Hilaire.

O catálogo das obras pertencentes a Brunet também revela um homem conectado com a política imperial. Há muitas «Falas» de presidentes das províncias às Assembléias Legislativas Provinciais, especialmente de autoria de Antonio Coelho de Sá e Albuquerque, presidente da província da Bahia como Francisco Gonçalves Martins. Martins presidiu a Bahia em duas oportunidades, de 1848 a 1852 e de 1868 a 1871. Albuquerque governou a Bahia entre 1862 e 1863.

Encontramos a primeira menção a Sá e Albuquerque na 23a Sessão da Diretoria do IIBA, em 05/06/1863, realizada no Palácio do Governo. Como os Presidentes da Província da Bahia eram automaticamente presidentes do Imperial Instituto, Sá e Albuquerque tratou com os demais diretores da realização de uma exposição agrícola, do intercâmbio de amostras, a periodicidade das sessões e, principalmente, da fundação definitiva da Escola. Na sessão seguinte de 21/06/1863 a criação da Escola foi pauta única do encontro, nomeando-se comissões encarregadas de elaborar as bases para a criação da Escola e sua Fazenda modelo.

Antônio Coelho de Sá e Albuquerque, segundo ROSADO e SILVA, foi o responsável pela indicação de Brunet para a construção de uma Escola de Agricultura que animava os debates das sessões do IIBA (ROSADO, SILVA, 1973: 305). Até a chegada de Brunet, em janeiro de 1864, o engenheiro Dionísio Gonçalves Martins, secretário-geral do IIBA, filho do Barão de S. Lourenço, tinha dirigido as primeiras obras.

O naturalista antes de assumir o cargo já tomava providências como negociações para a contratação de sete agricultores práticos que viriam do sul da França para as lides agrícolas, conforme as atas da 25 a Sessão da Diretoria do IIBA (01/09/1863). O apoio de Sá e Albuquerque, contudo, não durou, por conta da rotatividade dos presidentes de província. Aliás, esta rotatividade foi motivo de queixas da diretoria do IIBA e ainda na década de 1860 foi implementada a obrigatoriedade da residência na província para se exercer a presidência efetiva do Instituto, ficando o presidente da província na condição de presidente honorário. 
Designado para adquirir na Europa equipamentos, livros e espécimes para a escola, teve como substituto provisório Luís Blande Moreau (Atas do IIBA, 13/04/1871).

As cadeiras da escola começaram a ser estabelecidas. Também em março de 1871 foram nomeados examinadores dos programas apresentados para os Cursos de Botânica, Agricultura e Zoologia, Zootecnia e Veterinária, Trabalhos Práticos, Química, Física e Mineralogia elaborados por Brunet, Draenert e Moreau. O processo de revisão e aprovação dos programas elaborados pelos europeus indica a relevância que os agentes locais desempenharam na escolha e definição das atividades e modelos científicos a serem desempenhados.

O grupo revisor era composto por membros da Faculdade de Medicina da Bahia, Luiz Alves dos Santos, Virgílio Climaco Damásio, José Francisco da Silva Lima, e Antonio Mariano Bomfim (Atas do IIBA, 03/03/1871). Sobre o primeiro não localizamos informações, mas Virgílio Clímaco Damásio foi o proclamador da República na Bahia e seu primeiro (e efêmero) governador (SAMPAIO, 1998: 28). José Francisco da Silva Lima (1826-1910) foi um dos principais membros da «Escola Tropicalista Baiana» junto a John L. Paterson (1820-82), e Otto Wucherer (182073), desenvolvendo trabalhos sobre beribéri, ancilostomíase, filariose e ainhum (doenças associadas ao clima tropical) (EDLER, 2002). Antonio Mariano Bonfim também foi diplomado pela Faculdade de Medicina da Bahia, tornando-se seu professor além de ter sido um dos signatários do derradeiro decreto de criação da EAB em 1875.

Os programas constantes no Livro de Pareceres com as atas da diretoria do IIBA são as únicas fontes primárias onde localizamos maiores informações sobre a atuação de Moreau. Em nenhuma documentação compulsada consta a sua naturalidade ou formação. No "Parecer do Sr. Dr. Antonio Mariano do Bonfim sobre o programa do curso de Cultura e Agrologia", seu autor julga que o programa continha os principais pontos de tal curso, "revela somente acrescentar que na enunciação de tais pontos um ou outro descuido passou, que o Professor ilustrado corrigirá sem dúvida na exibição das lições". Não há, porém, informações sobre sua procedência, mas o detalhamento do programa, dividido em quatro anos e quarenta lições por ano.

No primeiro semestre do primeiro ano, de acordo com Moreau, correspondia ao Estudo do Solo, Elementos de Agrologia, Estudos do Subsolo, Semeamento dos terrenos, Rotearias, Cercas Rurais e Estudos dos Estrumes. No segundo semestre, continuação do Estudo dos Estrumes, Colheitas, Conservação dos produtos. No segundo ano, ao 
primeiro semestre corresponderia o estudo da Semeadura, Doenças das Plantas, Preparação do Terreno, Tratamento das Plantas e Instrumentos de cultura. No segundo semestre os tópicos eram Cultura geral das plantas, Cultura especial, Culturas das plantas sacariferas e Cultura das Plantas leguminosas.

Para o terceiro ano Cultura das plantas raízes e das plantas de forragem, no primeiro semestre, e Cultura das Plantas Oleaginosas, Tinturosas, Narcóticas e Têxteis. O último ano teria no primeiro semestre a Cultura dos vegetais arborescentes próprios dos países quentes e, para o último semestre, "desenvolverão os alunos uma tese agrícola, que serão obrigados a defender para obter o título de Engenheiro-Agrônomo. Esta tese compreenderá um plano de cultura para uma propriedade, cujas condições topográficas ser-lhes-ão apresentadas".

O "Parecer do Sr. Dr. Virgílio Clímado Damásio, sobre o programa de Física e Química apresentado pelo Sr. Maurício Draenert" tem maior riqueza de detalhes.

Frederico Maurício Draenert nasceu em Weimar aos 3 de Dezembro de 1838 e faleceu em 09 de setembro de 1903․ Formado na Alemanha em Weimar e Hamburgo, trabalhou na Escola de Instrução Superior para meninas, em Bützoro (Mecklemburg) e posteriormente em Hamburgo, em uma Escola de Instrução Secundária para meninos e o Ginásio Realista do Dr. H. Shleider, ensinando principalmente física e química. (BOLSEAGRIBA, 1903; IIBA. Livro de Pareceres, 12/04/1871).

Tendo analisado os certificados apresentados por Draenert, Damásio declarou que "é em resumo meu parecer: 1ํ que o candidato tem ensinado com louvor Física e Química em Colégios da douta Alemanha; $2^{\circ}$ que será incontestavelmente vantajoso que o ensine entre nós".

O primeiro contato de Draenert com o mundo do IIBA foi na sua contratação pelo Barão de Paraguaçu, Salvador Muniz Barreto de Aragão (membro do IIBA), quando este era Cônsul Geral do Brasil, em Hamburgo (1855), para instruir e educar os filhos de um abastado senhor de engenho em Iguape, Província da Bahia, funções que também desempenharia na casa de outro membro do IIBA, o Tenente-Coronel Francisco Antonio da Rocha Pita e Argollo, Barão de Passé, genro do Visconde de S. Lourenço.

3 "FREDERICO DRAENERT". BOLSEAGRIBA, Salvador-BA, vol. 2, n. 3, p.239-241, set., 1903.

4 No engenho S. Paulo, propriedade do mesmo Barão, estudou a moléstia da cana de açúcar. Descobriu então a primeira bacteriose, conhecida no reino vegetal (1868), descoberta publicada no 
Os Cursos de Física, Química e Mineralogia submetidos por Draenert estruturava-se da seguinte forma:

Primeiro ano de estudos

Primeiro semestre: Física e Meteorologia

Segundo semestre: Química geral

Primeira parte metalóides e ácidos

Segundo ano de estudos

Primeiro semestre: Química geral;

Segunda parte: metais, bases e sais.

Segundo semestre: Orictognosia e Geognosia.

Terceiro ano de estudos

Primeiro semestre: Química orgânica

Segundo semestre: Química agrícola e análise

Quarto ano de estudos

Primeiro semestre: Química industrial e Análise

Segundo semestre: Tese.

(Livro de Pareceres, 12/04/1871).

Em 1872, ocorre uma nova organização na direção dos trabalhos em S. Bento das Lages, dividindo-se o trabalho entre os três profissionais europeus em três seções. O contexto desta redefinição pelo IIBA é marcado pelo encerramento da direção interina das obras por Brunet, "visto estarem estas terminadas mandou se dar disto conhecimento ao interessado". Avaliando o estado da propriedade e a necessidade da montagem definitiva dos laboratórios e campos de cultura do estabelecimento, a Diretoria do IIBA resolveu pela reorganização do trabalho em S. Bento das Lages:

a divisão do trabalho em três seções fica sob a administração e direção do Sr. Brunet, que tem tido a seu cargo até o presente toda a administração das obras do Imperial Instituto. Cada seção é independente das outras, devendo o respectivo chefe dar mensalmente ao administrador Geral, conta do que fez durante esse tempo em um relatório circunstanciado acompanhado dos documentos comprobativos da despesa efetuada, ou paga por ele. (Atas do IIBA, 04/03/1872 - Grifo nosso). 
Em termos de atividades, à primeira seção confiada a Brunet concernia a preparação e montagem do museu, armação e classificação da livraria, cuidado das aves, porcos e veados pertencentes ao IIBA. Também lhe cabiam a inspeção e conservação dos edifícios terminados.

A $2^{2}$ seção apontava para a realização de atividades de prestação de serviço e pesquisa, além do ensino, na medida em que lhe cabiam a montagem e preparação dos laboratórios de Física e Química, conservação dos instrumentos dos mesmos, bem como análise das terras e estrumes, "todas as vezes que forem exigidas, e esclarecimentos sobre as matérias relativas aos mesmos assuntos, quando a Diretoria assim o exigir".

Quanto à terceira seção, confiada a Moreau, concernia "o tratamento dos quadrúpedes, das sementeiras plantadas ultimamente com as sementes vindas da Europa, preparação do terreno para os tabuleiros de cultura, destinados às experiências da escola, conservação das estradas, cercados" e às terras de S. Bento das Lages, em geral.

Num primeiro momento, pode-se pensar que Brunet tem neste momento que partilhar poder dentro do processo de organização da escola. Mas teria sido este encaminhamento do IIBA uma solução de compromisso com Brunet? Afinal ele não é mais o único diretor, status que doravante foi obrigado a partilhar, mas segue como administrador "geral".

De acordo com ROSADO e SILVA, a divisão de funções realizada pela diretoria do IIBA ocorreu movida também por conta de um conflito interno aos profissionais engajados. Após a volta de Brunet da Europa, Moreau integrava um conjunto de forças adversárias que tramou pela sua dispensa do cargo de diretor. Brunet, de acordo com estes autores, recorre desta decisão em carta datada de 6/4/1872, ao Visconde de Sergimirim, Antonio da Costa Pinto, então Presidente do IIBA:

Houve por bem ao Sr. Dionísio Martins destituir-me como diretor interino, isto a pedido do Sr. Moreau que lhe declarou não querer mais servir sob minhas ordens, porque eu tinha criticado o abandono no qual ele deixou a propriedade durante minha ausência e também porque eu havia usado de autoridade fazendo uma tentativa além disso infrutuosa para fazer meter no cural (sic) da cidade de São Francisco os bois de seu amigo o Dr. Ulisses, que após haver destruído inteiramente as sementes de cana que o governo do Rio nos havia confiado e igualmente as 
plantações do jardim que eu mantinha às minhas custas, continuavam a persistir no jardim apesar de minhas reclamações diárias.

Em seguida a esse pedido do Sr. Moreau a seu amigo Dionísio, a ata da sessão de 4 de abril foi sorrateiramente preparada entre eles, e o Sr. Dionísio, aproveitando-se do pedido que eu fazia à Direção de dois adjuntos, um o Sr. Drolnert (sic) para montar e conservar os objetos dos gabinetes de Física e Química, o outro o Sr. Peres para montar e preparar os objetos do gabinete de história natural, o sr. Dionísio encontrou tão habilmente o meio de iludir a Direção, dividindo o trabalho em três seções, independentes, que ela deixou passar sem duvidar em nada do que se tramava contra mim, a ata da sessão de 4 de abril, cuja redação de resto não foi conhecida senão no dia seguinte.

Além do que há de ofensivo para mim na destituição como diretor interino que não penso haver merecido, sobretudo no momento em venho de desenvolver os maiores esforços e sacrifícios para realizar na Europa o melhor possivel a missão com que aprouve a $V$. Excelência honrar-me; por outro lado afirmo, foi feito para cada seção um orçamento de despesas onde a parte feita para os animais fica inteiramente à disposição do Sr. Moreau; (...)

Em primeiro lugar, não posso deixar passar minha destituição sem protesto perante $V$. Excelência (rasgado) à justiça da qual me confio.

Em segundo lugar, devo dizer-lhe que não posso aceitar frente a frente com o Sr. Moreau, a sujeição humilhante que me foi imposta.

(BRUNET apud ROSADO, SILVA, 1973: 309)

Dionísio Gonçalves Martins foi designado para o cargo de secretário efetivo do IIBA em 1870. Moreau, por outro lado, foi o substituto de Brunet quando de sua viagem à Europa.

Só é possível especular se a origem das diferenças entre Brunet e Dionísio esteve na substituição deste pelo francês na condução das obras da escola. O que podemos localizar é que Brunet levou, a principio, a melhor sobre Moreau, pois este foi dispensado em junho do 
mesmo ano, por diferença de um voto, sendo demitido apesar do apoio de Dionísio Gonçalves Martins ${ }^{5}$. O triunfo de Brunet durou poucos anos. No fim de 1875 o médico Arthur Cezar Rios foi nomeado Diretor da Escola (Atas do IIBA, 30/11/1875).

Brunet não foi totalmente dispensado. Estava ainda nos quadros da Escola como professor de ciências naturais. Contudo, suas seguidas licenças para tratamento de saúde na Europa culminaram no afastamento definitivo ${ }^{6}$. Assim, ao fim e ao cabo, no momento de funcionamento da escola, havia apenas um cientista europeu: Frederico Maurício Draenert. No decorrer de sua primeira fase, a Escola de São Bento das Lages teve que contar fundamentalmente com um corpo docente brasileiro. Draenert foi lente da cadeira de Física, Química e Mineralogia desde um semestre experimental iniciado em julho de 1876, passando pelo início oficial das aulas em 1877 até 1887, quando sai da Escola Agrícola da Bahia. Dos dezesseis professores da Escola em sua primeira fase (1877-1904), Draenert foi o único estrangeiro (EAB. Livros de atas da Congregação. 1876-1883, 1883-1895).

Assim, por um lado, tanto as decisões da diretoria do IIBA, quanto a avaliação dos programas propostos pelos profissionais europeus por um corpo de pareceristas locados na Bahia, como o domínio de brasileiros no corpo docente da EAB, indicam a relevância dos agentes locais na institucionalização da agronomia no caso em foco. Por outro lado, pode-se localizar que as escolhas e a organização dos conteúdos programáticos se ampararam e adaptaram não só em modelos institucionais externos, mas na atuação direta de profissionais estrangeiros. $O$ decisivo na mediação das dimensões brasileira e européia foi a existência prévia de vínculos sociais e científicos, pois tratou-se de profissionais europeus que já tinham laços com membros da diretoria do Imperial Instituto da Bahia.

5 "Por proposta do Sr. Pinto Novaes, foi demitido das funções que exercia em S. Bento das Lages, o Sr. Luis Moreau, passando o Sr. Brunet a exercer as funções que outrora exercia de Diretor exclusivo do estabelecimento. Votaram a favor da proposta os Srs. Pinto Novaes, Geremoabo e Barros Reis, e contra os Srs. Barão de S. Thiago e Dionísio Gonçalves Martins" (Atas do IIBA, 06/06/1872).

6 "Leu-se uma carta do L. J. Brunet pedindo prorrogação da licença, e foi deliberado pela Direção que se escrevesse ao referido Senhor dispensando-o do cargo de lente de História Natural, Botânica, Zoologia, etc., não só por estar perfeitamente substituído pelo Dr. João Ladislau de Cerqueira Bião, como por ter o referido Sr. transgredido o regulamento pedindo nova licença, depois de vencida a primeira" (Atas do IIBA, 21/11/1876) 


\section{Iconografia}

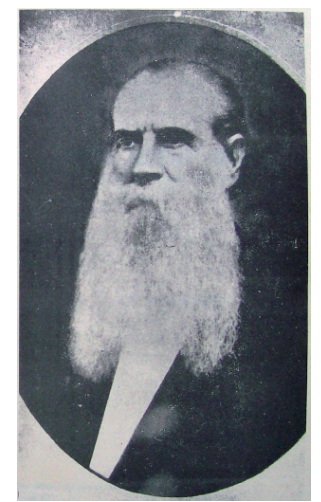

1. Luis Jacques Brunet

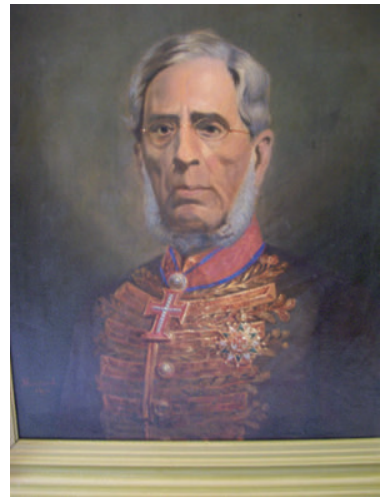

2. Francisco Gonçalves Martins

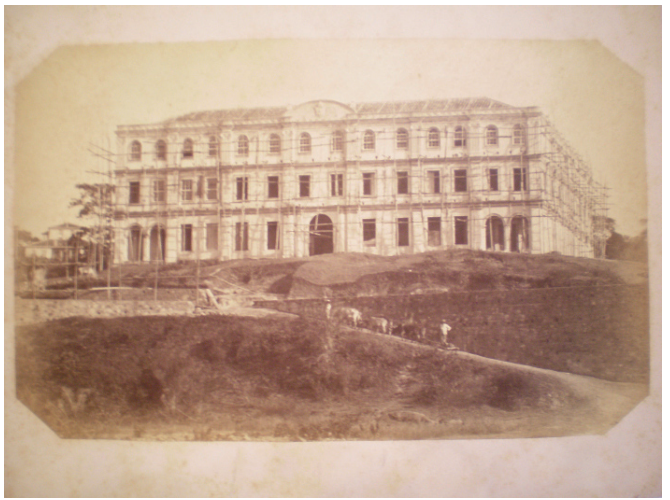

3. Obras da Escola Agrícola em 1872, sob direção de Brunet. 


\section{Referências}

ARAÚJO, Nilton de Almeida. Pioneirismo e Hegemonia: a construção da agronomia como campo científico (1832-1911). Niterói, RJ: [s.n.], 2010.

BAIARDI, Amilcar. "O Papel do Imperial Instituto de Agricultura na Formação da Comunidade de Ciências Agrárias da Bahia, 1859-1930". In Seminário Nacional de História da Ciência e Tecnologia (7:: 1999: São Paulo) VII Reunião de Intercâmbios para a História e a Epistemologia das Ciências Químicas e Biológicas. Anais/José Luiz Goldfarb \& Márcia H. M. Ferraz (orgs.). São Paulo: EDUSP: EDUNESP: Imprensa Oficial do Estado: SBHC, 2001.

BOLSEAGRIBA,."FREDERICO DRAENERT". Salvador-BA, vol. 2, n. 3, p.239241, set., 1903.

CAPDEVILLE, Guy. O ensino superior agrícola no Brasil - Viçosa, UFV, Impr. Univ. 1991.

DOMINGUES, H. M. B. Ciência, um Caso de Política: as relações entre as ciências naturais e a agricultura no Brasil Império, 1995. Tese de doutorado, São Paulo: FFLCH-USP.

EAB. Livros de atas da Congregação. 1876-1883, 1883-1895

EDLER, F. C.: .A Escola Tropicalista Baiana: um mito de origem da medicina Tropical no Brasil.. História, Ciências, Saúde. Manguinhos, Rio de Janeiro, vol. 9(2):357-85, maio-ago. 2002.

IIBA. Livro das Atas do Imperial Instituto Bahiano d'Agricultura. 18591902.

IIBA. Livro destinado para o registro das representações que dirigir o Instituto a Sua Majestade, o Imperador, 1860-1867.

LOPES, M. Margaret. O Brasil descobre a pesquisa científica: os museus e as Ciências naturais no século XIX. São Paulo: HUCITEC, 1997

OLIVER, Graciela de Souza. O papel das escolas superiores de agricultura na institucionalização das ciências agrícolas no Brasil, 1930-1950: práticas acadêmicas, currículos e formação profissional. Campinas, SP : [s.n.], 2005. 
ROSADO, Vingt-un e SILVA, Antonio Campos. Louis Jacques Brunet, naturalista viajante. 1ำ vol. Natal, CERN, 1973.

SAMPAIO, Consuelo Novais. Os partidos políticos da Bahia na Primeira República: uma política de acomodação. Salvador, Editora da Universidade Federal da Bahia, 1998.

\section{Lista das figuras - Créditos}

1. Louis Jacques Brunet - ROSADO e SILVA, 1973.

2. Francisco Gonçalves Martins - Memorial da Agronomia da Universidade Federal do Recôncavo da Bahia em Cruz das Almas.

3. Obras da Escola Agrícola em 1872, sob direção de Brunet. - Seção de Iconografia da Biblioteca Nacional. 


\title{
A "Atraente Escola de Intuição": o Jardim Zoológico e o Horto Botânico do Museu Paraense de História Natural e Etnografia (1897-1900)
}

\author{
Diego Ramon Silva Machado \\ José Jerônimo de Alencar Alves ${ }^{2}$
}

Em 1897, uma das maiores novidades arquitetônicas e científicas da Belle Époque começou a surgir dentro da cidade de Belém. Tratou-se do Horto Botânico e do Jardim Zoológico do Museu Paraense de História Natural e Etnografia, ambos erigidos como anexos na nova sede da Instituição adquirida por intermédio do governo estadual. Sob a direção de Emilio Goeldi, naturalista suiço contratado em 1894 por Lauro Sodré, Governador do Estado, o Parque Zoobotânico do Museu tornouse sinônimo de progresso e instrução no Estado. Em suas dependências, em meio a árvores e viveiros importados, os visitantes poderiam ter o contato direto com os "objetos da natureza", por meio da observação de plantas e animais vivos.

Tanto a contratação de Goeldi, quanto o projeto dos anexos foram reflexos da administração governamental de Lauro Sodré. De fato, o Governador foi reconhecido por alguns historiadores (SARGES, 2002; ALVES, 2005b; SANJAD, 2005) por conceber uma administração com traços positivistas, além de ser considerado como um dos principais incentivadores do "programa civilizador em Belém" e um dos mais ativos "propagandistas da República" de sua época (SANJAD 2005, p.141-143).

1 Mestre em Ensino de Ciências - IEMCI/UFPA. Doutorando em História das Ciências e da Saúde pelo Programa de Pós-Graduação em História das Ciências e da Saúde - COC/FIOCRUZ

2 Doutor em História Social - USP. Professor colaborador do Programa de Pós-Graduação em Ensino de Ciências e Matemáticas do Instituto de Educação Matemática e Científica - IEMCI/UFPA. 
Historicamente, Sodré foi responsável pela reforma e florescimento de Instituições científicas, culturais e educacionais. Destacam-se, neste rol, as obras no Teatro da Paz, do Instituto Paraense de Artífices (Instituto Lauro Sodré), Colégio Nossa Senhora do Amparo (Colégio Gentil), Associação Protetora dos Órfãos, Sociedade de Estudos Paraenses, Casa de Misericórdia; e a criação do curso de Agrimensura no Liceu Paraense, justificado pelo crescimento da cidade, e do Liceu de Artes e Ofícios (Liceu Benjamin Constant) - sob a direção da Sociedade Propagadora do Ensino - com o objetivo de proporcionar o "derramamento da luzes das ciências pelas classes populares"; além da revitalização da Biblioteca Pública e do Museu Paraense (SODRÉ, 1891 p. 9).

Em efeito, a preferência pela contratação de Goeldi como Diretor do Museu Paraense representou a vontade de Sodré em colocar "homens da ciência" para cargos de liderança. A nacionalidade européia representou um ponto importante para a escolha de Goeldi, principalmente por este viver no lugar considerado por muitos homens de seu tempo como o celeiro do pensamento cientifico na época; além disso, o novo Diretor havia passado por grandes Institutos estrangeiros como a estação zoológica de Nápoles, na Itália, onde estudou peixes e aves, partindo posteriormente para a Alemanha em 1881, fazendo neste local os cursos de Zoologia e Anatomia Comparada nas Universidades de Leipizig e Jena, desenvolvendo estudos anatômicos, históricos e evolutivos, como assistente de Ernst Häckel.

Em Belém, a nomeação de Goeldi foi acompanhada de promessas de apoio e auxilio moral as suas atividades como o próprio Diretor declarou em carta circular enviada a Lauro Sodré (GOELDI, 1894a p.8-10). Na carta estava claro que o Governo, desde a sua contratação, tinha em vista uma nova sede para o Museu, um edifício apropriado, com capacidade para permitir a evolução e o aumento gradativo de suas coleções e anexos como o Jardim Zoológico e o Horto Botânico. A relação amigável de Goeldi com outras Instituições e especialistas - como no caso de seu colega e amigo: o diretor do Museu Paulista Dr. Hermann Von Ihering também representou um ponto forte na sua investidura de cargo, pois possibilitava a troca de conhecimento e a permuta de resultados de pesquisa entre os estudiosos. Goeldi louvou ainda os esforços de Sodré pela tentativa de elucidar as partes obscuras da ciência e pelo muito que contribuiu para o desenvolvimento do ensino popular no Estado. Complementarmente, o novo diretor do Museu reforçou que, segundo 
- Governador paraense, a instituição a ser revitalizada era antes uma "criação" do que uma reforma:

"Verá que digo CREAR, pois o que temos nem de
museu merece o nome, tão pouco é, tão desali-
nhado e fora de regra e longe de ciência anda aquilo
tudo que dói o ver o contraste entre esta tamanha
pobreza acumulada e a enorme riqueza que anda à
mão no seio da natureza aqui" (SODRÉ apud GOELDI
1894a p.9)

Ainda na carta-circular enviada a Sodré, o Diretor Emilio Goeldi (1894a p.9) julgou interpretar de maneira nítida as intenções do Governo do Estado quanto à criação do Museu ao definir, em primeira linha, o Museu Paraense como um "instituto para a História Natural do Amazonas, um estabelecimento que se propõe observar, colecionar, determinar e tornar conhecidos os objetos da natureza indígena".

Diante das mudanças do Museu, sobretudo arquitetônicas, Sodré (1894b, p.26) recomendou a atenção dos poderes públicos ao Museu Paraense, que segundo ele era uma criação recente devido à grande diferença entre a Instituição existente e a "coisa amorfa, que sob esse titulo figurara entre os estabelecimentos públicos do Pará" anos antes da sua revitalização.

Portanto, em meio a essas relações históricas de revitalização, apoios governamentais, práticas cientificistas e transformações no espaço do Museu é que construímos a nossa análise investigativa. De maneira mais enfática nosso objetivo neste artigo é analisar a difusão da História Natural promovida pelo Museu Paraense de História Natural e Etnografia no Pará, durante o final do século XIX, a partir da criação dos dois anexos já citados: o Parque Zoológico e o Jardim Botânico (1897). Partimos da idéia de que estes ambientes foram estratégias efetivas de difusão da História Natural no Pará durante o final do século XIX, especialmente pela proposta de ensino contida nela.

Atualmente, pesquisas históricas (ALVES, 2005a; CRISPINO, 2006 e SANJAD, 2005) mostraram a importância da criação do Jardim Zoológico e do Horto Botânico, sobretudo no processo de Institucionalização do Museu Paraense durante os primeiros anos da República. No entanto, apesar dos trabalhos identificarem como estes anexos surgiram, além da sua relação com a difusão da História Natural no Pará, pouco se sabe sobre a história da educação científica ocorrida nas suas dependências, ou mesmo em Museus de História Natural como um todo e muito menos sobre suas estratégias e métodos de ensino. 
Ressaltamos que estamos considerando como difusão todo o meio de transmissão de conhecimentos, seja por meio de cursos, revistas, publicações e/ou instrução popular. Frisamos ainda que nos documentos históricos referentes ao Museu Paraense este termo não aparece, porém é muito comum a terminologia "vulgarização científica", entendida no século XIX, como a "ação de falar de ciência para os leigos" (VERGARA, 2008 P.137). No entanto, neste trabalho, preferimos utilizar o termo difusão científica por considerá-lo mais abrangente, uma vez que - segundo Zamboni (2001, p.46) - concebido de maneira tão larga, a palavra difusão engloba, tanto a difusão para especialistas (Disseminação Científica), quanto a difusão para o grande público em geral (Divulgação Científica).

Para compreender esta estratégia de difusão da História Natural tomamos como base dois materiais de pesquisa: os relatórios e as mensagens oficiais dos Governadores do Estado, entre os anos de 1897 a 1903, sobretudo, na parte referente ao Museu Paraense ${ }^{3}$; e o Boletim do Museu Paraense de História Natural e Etnografia (1895-1900), por relatarem a idealização e a implementação dos anexos durante o período em estudo.

\title{
De Museu em miniatura a sucesso de público
}

\begin{abstract}
Como se sabe, o Museu compõe-se de um edifício contendo coleções e um apêndice atrás, servindo de "sala de dissecação". O primeiro é de aspecto simpático, mas as suas dimensões exteriores traem logo, que não se trata de outra coisa senão de um Museu em miniatura, de um mero "gabinete".

Emilio Goeldi - Relatório sobre o estado do Museu (1894)
\end{abstract}

O "museu em miniatura" se constituía em problema para os planos do novo Diretor da instituição pois a ordem arquitetônica daquele prédio o impedia de crescer para qualquer um dos lados. Seu estado de conservação, segundo Goeldi (1894c, p.18), também deixava a desejar

3 Estas comunicações emitidas anualmente apresentam uma síntese das atividades em cada Província e podem ser encontrados na íntegra (1830-1930) no site do Center of Research Libraries, sendo referente ao Latin American Microform Project (LAMP) que proporciona o acesso, via internet, aos documentos e facilita a sua utilização por Pesquisadores, dando apoio às pesquisas históricas latino-americanas. Maiores detalhes no site: http://www.crl.edu/brazil 
com goteiras e telhados necessitando de consertos, que tiravam absolutamente as chances do prédio servir para um Museu reorganizado. Estes fatores fizeram Goeldi indicar o quanto seria melhor se houvesse a transposição do novo Museu para um edifício apropriado ao desenvolvimento e aumento das coleções, e que desse, por ocasião, para organizar os anexos desejados como "um modesto Jardim Zoológico e um pequeno Horto Botânico".

No relatório enviado ao Governador em 1895, Goeldi continuou a fazer críticas ao edifício antigo do Museu Paraense, afirmando que seria mais viável a construção de um prédio novo que abrigasse de maneira favorável as coleções existentes. No entanto, o Diretor reconheceu que uma nova edificação renderia muitos anos, mesmo que já houvesse estabelecido a localidade com antecedência. Além disso, o Museu não poderia mais permanecer com sua existência "obscura e ignóbil", meramente vegetativa, principalmente por não permitir nem o trabalho científico, nem a visitação pública em seu recinto, como fica claro no seguinte trecho:

\begin{abstract}
Como se previu que semelhante edificação exigiria muitos anos, mesmo no caso de achar-se já conhecida, determinada e adquirida a localidade, e que durante estes anos todos o Museu seria forçado à continuação da mesma existência obscura e ignóbil (existência meramente vegetativa, que não permitia qualquer tentativa de trabalho científico e dentro do recinto, nem representação condigna e relações razoáveis com o público e o mundo exterior), resolveu-se escolher um edifico já existente, com dimensões suficientes pelo menos para um certo número de anos. (GOELDI, 1985 p.218)
\end{abstract}

Diante das críticas, não tardou muito para que os pedidos de Goeldi fossem concretizados pelo Governo do Estado. Assim, em 1895 (p.218219) o novo Diretor do Museu relatou que um novo prédio foi doado à Instituição dentro da cidade de Belém, entre a estrada da Independência, a travessa nove de Janeiro e a estrada da Constituição, hoje conhecida como Gentil Bittencourt. Segundo Goeldi, a grande disposição arquitetônica interior, sólida estrutura, dimensões, conservação esmerada, aspecto ameno, terreno amplo, entre outros fatores relevantes permitiram a criação dos anexos e o aumento das coleções, mesmo que a preferência fosse a construção de um prédio novo. A localização da rocinha recém-comprada também ajudou na consolidação do novo Museu. Com bondes a sua frente e estrada de ferro aos fundos, a 
Instituição tinha mais possibilidade de sucesso, pois o terreno havia de se tornar parte do centro da cidade devido seu crescimento naquela direção, junto à possibilidade de valorização dos imóveis próximos com o passar dos anos ${ }^{4}$.

Todavia, Goeldi (1895, p.220) não ressaltou apenas a importância da nova arquitetura e localidade do Museu. Ele relacionou também a criação do Horto Botânico e do Jardim Zoológico a um destino mais digno do Museu Paraense, além da sua "utilidade" e das "vantagens palpáveis" para a Instrução Pública, batendo de frente com os céticos e os descrentes sobre os anexos. O Diretor comparou as novas dependências da Instituição a "uma atraente escola de intuição das obras da natureza amazônica", onde seria facilitada a visitação pública.

\begin{abstract}
Queremos criar uma atraente escola de intuição das obras da natureza amazônica para o público e pretendemos facilitar o acesso, abrindo os ditos anexos, logo que for possivel, diariamente. Repetimos sempre e sempre que não é nosso intuito querer imitar os grandes jardins e hortos de além-mar, para onde o orbe inteiro tem que mandar sua contribuição em produções notáveis do reino animal e vegetal. Não almejamos nem o elefante da Índia, nem a girafa do continente Negro. Queremos o que é nosso, o amazônico, o paraense e não será preciso que eu (que não nasci nesta terra e que hoje não me vejo aqui por nenhum outro motivo senão o amor à ciência e à vontade de criar aqui na Amazônia um sólido reduto para ela) tenha de mostrar ao povo paraense, que a natureza, que nos cerca, tem material de sobra, para encher condignamente tanto um Jardim Zoológico, como um Horto Botânico. (GOELDI, 1895 P. 220)
\end{abstract}

A escola de intuição desejada por Goeldi contrapôs a escola baseada simplesmente nos manuais de História Natural. Assim, quer seja no Horto Botânico, quer seja no Jardim Zoológico, a visão alcançou o patamar de

4 Anos mais tarde Paes de Carvalho (1901, p.64), Governador do Pará, afirmou que após a estadia em sua nova sede o Museu Paraense passou por outras mudanças além das ocorridas nos anexos. Entre as obras, instalação de oficinas e laboratórios, construção e reformas das moradias de seus funcionários, ampliação da exposição e condicionamento do acervo. A relação entre o ambiente profissional e o ambiente doméstico, segundo Sanjad (2005, p.169), misturou-se no Museu Paraense obrigando seus Pesquisadores, técnicos e operários a darem exclusividade ao local, independente de seus compromissos pessoais e familiares. 
primazia diante dos outros sentidos. O Diretor valorizou o papel pedagógico do Museu Paraense chegando a afirmar que o visitante, ao examinar os exemplares vivos do Horto, por exemplo, lucraria muito mais do que lendo manuais de botânica, caso existissem (GUALTIERI, 2005, p.109). A observação, portanto, foi vista enquanto agente responsável por educar e aperfeiçoar os sentidos possibilitando ações inerentes à aprendizagem como perceber, abstrair, analisar, comparar, generalizar e sintetizar.

Neste sentido, o Museu Paraense adotou a premissa de uma prática de ensino pautada no ver para compreender, pela observação direta do público aos objetos da natureza expostos nos ditos anexos; pressupostos pedagógicos do método intuitivo de ensino, conhecido também como "lição de coisas", ou "ensino pelo aspecto"5. O marco desta visão de mundo aparece neste momento histórico de maneira relevante como distinção entre o ensino memorístico e o verbalista, pautados na oralidade do instrutor, e o ensino intuitivo, onde o sujeito visitante passa a ser o protagonista da sua história educacional por meio do contato direto com os fenômenos naturais e os objetos circundantes, desta maneira:

La creencia que la inteligencia del sujeto, enfrentada directamente a los objetos, la permitiria descubrir su naturaleza era el punto de justificación y de partida de todas las iniciativas de la pedagogia basada em las "cosas". Com ello se esperaba que el niño alcanzara um conocimiento verdadero y uma nueva manera de relacionarse com el mundo real a partir de la observación y reflexión sobre los objetos que conformaban su entorno (GARCIA, 2007 p.176).

Segundo Valdemarin (2004 p.94-109), o contato com as "coisas" possibilitaria aos alunos aprender os dados inerentes de cada objeto, numa premissa didática de "colocar as idéias frente à necessidade de nascer". Aqui, o método intuitivo, sobretudo, tornou-se adequado ao campo das Ciências Naturais, pois seu conteúdo de ensino pôde ser apresentado aos alunos de modo atraente e prático, dentro da relação próxima com

5 De acordo com Valdemarin (2004; 2006 p.89-117), as concepções teóricas e procedimentos didáticos da "lição de coisas" foram amplamente difundidas nas escolas do Brasil por dois livros: - Méthode intuitive - Exercises et travaux pour lês enfants selon la méthode et lês procedes de Pestalozzi et de Froebel de Charles Delon (1892; 1913) e Fanny Delon (1913) com o objetivo de orientar a prática pedagógica de professores Instituições infantis; e as Primeiras lições de coisas de Normam Alison Calkins (1950), traduzido por Ruy Barbosa, livro importante na implantação do método de ensino intuitivo na educação brasileira, com a função de "evidenciar as diretrizes teóricas apresentadas pelo autor e compreender o processo pelo qual uma determinada concepção epistemológica pode ser traduzida num conjunto de prescrições metodológicas para o ensino, desdobrando-se em lições, exercícios e atividades". 
"a compreensão dos usos industriais dos elementos naturais e do trabatho desenvolvido pelo homem para este fim".

Nesta interpretação, as gravuras e os desenhos ganharam um lugar especial, visto que por eles haveria condições de aprendizagem quando não ocorresse a observação direta dos objetos de estudo e fenômenos naturais. Deste modo, as ilustrações, por tratarem de articular uma "visão científica e estética da natureza" decorrente à participação de naturalistas e artistas na sua confecção, retratavam fielmente o que muitos alunos não poderiam ver diretamente no mundo natural (GARCIA 2001, p.178). Ou seja, ao definirem cores e formas das estruturas dos organismos as imagens promoveriam a aprendizagem e a representação mais interessante da natureza para o estudante. Neste aspecto, catálogos, fichas de identificação e livros constituíam grande possibilidade de aproximação destas figuras com a "coisa" real. Utilizadas, por exemplo, para lições de morfologia dos organismos as figuras utilizadas na compreensão do texto escrito e nas aulas presenciais apresentaram-se como indispensáveis no ensino da ciência da natureza, facilitando o reconhecimento das características físicas dos organismos.

No novo método, portanto, a disciplina história tinha importância por meio de traços materiais e acontecimentos contemporâneos observáveis; a geometria, pelo manuseio de objetos geométricos presentes do dia-dia de cada estudante; o desenho, por suas implicações artísticas e industriais com a ornamentação e construção dos objetos do mundo natural; a leitura e a escrita, por intermédio da reflexão tida como observação do próprio pensamento fazem parte da abrangência capilar do ensino intuitivo. Porém, a principal inovação do currículo na época foi a introdução do estudo da natureza na educação pré-escolar, principalmente:

[...] pelo fato de possibilitar o conhecimento da forma, da força e do movimento, elementos presentes em vários aspectos da vida, sejam eles concretos ou abstratos. E para essa aprendizagem, a observação é o atributo humano que proporciona a percepção e a compreensão da forças naturais, por meio da constatação das propriedades da matéria, da aquisição de noções sobre as rochas, a vida das plantas e os hábitos dos animais, gerando assim um conhecimento, ainda que sumário, da própria organização humana. (VALDEMARIN, 2006 p.94) 
Todavia, na História do Museu Paraense, Goeldi não foi o primeiro a fazer a relação entre o Museu e o método da "lição das coisas". Em 1890, José Veríssimo, Diretor da Instrução Pública no Pará e um dos grandes responsáveis pela reorganização do ensino primário, secundário, técnico, particular e público (Biblioteca Pública e Museu Paraense) no Estado, também se pronunciou sobre a maneira de educar por meio de Museus de História Natural - definido por ele como local de "educação popular", nova instância da Instrução Pública, onde se encontravam o Museu Paraense e a Biblioteca Pública, ambos fiscalizados e organizados pela Diretoria Geral. Na sua concepção para que o Museu Paraense pudesse ser uma "eloqüente", "interessante" e "instrutiva" Instituição, ou como ele próprio preferiu chamar, ser a "lição das coisas", precisaria que todos os objetos da natureza - macacos empalhados, pontas de lança, vasos de cerâmica, exsicatas de plantas - fossem arranjados sistematicamente e classificados de maneira rigorosa para assim promover uma noção "exata, clara e precisa" dos objetos da natureza aos seus visitantes:

Como elemento da instrução popular, um Museu é uma eloqüente, instrutiva e interessante, para falar a linguagem pedagógica, lição de coisas. Para que realmente o seja, não se dispensa também o arranjo sistemático das coleções, a classificação rigorosa dos objetos dando aos visitantes ao mesmo tempo uma noção exata, clara e precisa de cada coisa exposta e da classe a que pertence, o seu nome, a sua utilidade, a sua origem ou qualquer outro elemento necessário ao seu conhecimento (VERÍSSIMO, 1894 p.7).

Ou seja, para que o Museu Paraense, após sua reestruturação, pudesse satisfazer seu fim de guardar a história e a memória de um povo, ele precisaria ser mais que simplesmente uma "mera acumulação de raridades, mais ou menos curiosas". Era preciso que além de objetos raros, o local também estivesse "sistematicamente disposto" e "cientificamente arranjado", para assim promover o ensino da História Natural no próprio estabelecimento. Ou seja, era necessária a "organização" do mesmo com "sistema", "método" e "ciência". Valores obfirmados por Veríssimo que comparou a reorganização do Museu, a reabertura de uma "boa escola", além de imprimir os votos de que a instituição fosse proveitosa na sua função. Todavia, para isso era preciso convergir para o Museu todos os esforços necessários de seus envolvidos (VERÍSSIMO 1894, p.7-8). 
Assim a referida procura pelo status científico do estabelecimento foi reforçada por meio das classificações e da arrumação sistemática e metódica de seus objetos expostos, práxis reconhecida nos ideais científicos da História Natural durante o século XIX, sustentada na mensuração, na quantificação e também na identificação morfológica rigorosa dos materiais coligidos na região. Ora, uma vez que a busca por uma rigorosidade metódica na organização dos objetos expostos no Museu Paraense foi explorada por Veríssimo em seu pronunciamento, torna-se latente a inserção do Diretor no modelo de "racionalidade científica" do século XIX.

Sodré (1897, p.34-35), igualmente, comentou a relação entre os anexos criados no Museu Paraense e a educação científica local, pois para ele no Horto Botânico e no Jardim Zoológico havia sempre uma "ensinação a receber". Segundo o Governador o Museu servia aos interesses do ensino público, pois "naquelas salas, para onde as coleções cientificamente organizadas atraem os visitantes em massa, há uma útil lição de coisas." Sodré citou neste rol de mudanças as conferências, destinadas a construir cursos populares e constituir a prática de visitas escolares; e o Boletim do Museu Paraense com o objetivo de tornar conhecida as experiências e as produções científicas dos Pesquisadores do Museu Paraense $^{6}$.

No Jardim Zoológico e no Horto Botânico, nada de animais ou plantas exóticas de continentes distantes, ali se buscou mostrar o genuinamente amazônico, o paraense. Diante das gaiolas, ou entre os corredores de árvores frondosas, o público visitante aprendeu cada vez mais sobre os objetos da natureza amazônica, e isto tornou o Museu Paraense exclusivo entre seus congêneres. Em suas dependências houve sempre algo novo a aprender, principalmente nas coleções expostas e nos anexos com espécimes vivas?.

6 Quanto às conferências e o Boletim do Museu Paraense e sua relação com o ensino da História Natural no Estado escrevi um texto dissertativo denominado A "Lição de Coisas": O Museu Paraense e o ensino da História Natural (1889-1900). Nele enfatizo o quanto estas duas estratégias contribuíram para a consolidação da educação cientifica no Pará.

7 No seu discurso, Goeldi se mostrou preocupado com o pensamento de alguns paraenses, a respeito do Museu, que diziam já ter visto todos os tipos de espécimes presentes no Parque Zoobotânico da Instituição. Pensamento, diga-se de passagem, retrucado por Goeldi (1895) - ao citar Buffon que diferenciou o homem instruído do inculto, não pela soma do seu saber e sim pela maneira e o modo como ele vê o mundo natural. 
$\mathrm{Na}$ tentativa de abarrotar os anexos com a fauna e a flora pátria, Goeldi fez uma espécie de "regionalização" do Museu Paraense ${ }^{8}$. A partir de então os visitantes passaram a conhecer melhor aquilo que thes circundava, todavia dentro da sistematização defendida pelas Ciências Naturais do período. Dentro e fora do Museu os organismos passaram a ter nomes binomiais, de acordo com as normas taxonômicas; informações sobre sua alimentação, habitat, entre outros caracteres que os tornassem diferentes uns dos outros e lhes dessem, com isso, a sua individualidade diante dos olhos dos naturalistas. Assim, ao passar pelos muros do estabelecimento os visitantes do Museu vivificaram e conheceram a natureza dos animais e plantas, de onde provinham suas necessidades e os seres que nos precederam.

A tal "regionalização", porém, se limitou apenas à "parte viva" do Museu, porque as edificações, incluindo os anexos, seguiram a arquitetura européia como outras construções na capital durante o período da Belle-èpoque. Assim, para o bom caminhar do Parque Zoobotânico, jardinagem esmerada, colocação de janelas sólidas e apropriadas, grades de ferro, viveiros de arame, tanques cimentados para animais aquáticos e letreiros, os últimos sujeitos a freqüente variação (GOELDI, 1895 p.221). Internamente, quase tudo lembrava a Europa como um lago das vitóriasrégias semelhante ao Mar Negro da Rússia, laboratórios e residências em formato de chalés Suiços, uma torre de observações meteorológicas e astronômicas parecidas a Torre Eiffel, só que em proporções menores, e aves aquáticas morando sob cobertura igual ao "Parc St. Germain" e banhando-se no modelo do italiano Lago Maggiore, formaram o cenário distante trazido por Goeldi para Belém (SANJAD, 2005 p.171-172; GOELDI, 1897 P.1-27).

Segundo o Governador Paes de Carvalho (1898) no Parque Zoobotânico a relação do Museu Paraense com a educação foi patente e responsável por fazer do estabelecimento um ambiente que, tecia de antemão uma "parte excepcional no ensino superior", que mais cedo, ou mais tarde, o Estado teria de fundar. De fato, Dantes (2001), sobre esta relação entre as instituições científicas e o ensino superior, afirma que no caso das Ciências, na ausência de Universidades, coube aos diversos Institutos científicos - Museu Paraense, Observatório Nacional, Comissão Geológica do Império, Instituto Histórico e Geográfico Brasileiro, entre outros - a responsabilidade da formação superior.

8 Podgorny (2000), citado por García (2007, p.182), fala a respeito da criação e exibição de coleções de História Natural e seus respectivos catálogos implicando numa espécie de "argentinização" da fauna, da flora, dos minerais e fósseis, achados e estudados em território argentino por Museus locais como uma espécie de nacionalização das Ciências Naturais. 
Em outro momento Paes de Carvalho (1901, p.65), firmou a prosperidade das dependências do Museu com base nos melhoramentos arquitetônicos, no crescimento da biodiversidade interna do Museu Paraense pelas doações quotidianas e na visitação pública. De acordo com o governante, impressionavam a todos a "grande e magnífica casa de feras", o terrário para os répteis, além de outras acomodações preparadas para as aves de rapina, mamíferos, etc ${ }^{9}$. Os donativos quase diários de novos exemplares e a crescente freqüência em dias de exposição testemunhavam o apreço público pelo estabelecimento, visitado por 334.641 pessoas entre os anos de 1897 e 1901, às terças e quintas-feiras.

Assim, numa cidade com um pouco mais de 177.000 mil habitantes (1906), ter em média de 85 mil visitantes anuais foi, sem dúvida nenhuma, uma quantidade expressiva. Em 1907, por exemplo, o número de visitações chegou a 124.670 pessoas, ou seja, mais da metade da população da capital de um ano antes, enquanto em 1894 apenas 950 pessoas haviam passado por ali ${ }^{10}$.

Estava instituída a atração do público pelo Museu Paraense, apoiada fortemente no seu número de visitantes. Os estudos de Sanjad (2005, 2008) afirmam que naquele tempo, pessoas de diversos pontos da Capital e até de fora dela visitaram o Parque Zoobotânico, estimuladas por Goeldi a contemplar os mais diversos animais capturados nas viagens e excursões, ou trazidos por correspondentes e colaboradores. $O$ único exemplar vivo de Pirambóia exposto em um Museu em seu "tanque europeu", os filhotes de onças enjauladas, garças e emas nidificando, porquinhos da índia e outros pequenos roedores, pacas, pássaros, disputavam atenção de homens e mulheres a que podiam quase tocá-los. No horto, árvores de copaíbas, jarinas, açaizeiros, mangueiras e o "viveiro de plantas em latas" formavam corredores de clima ameno ao lado da arquitetura européia das rocinhas, viveiros e lagos. Mudanças responsáveis pela formação de uma "colônia científica" no meio da Amazônia representando, na verdade, uma espécie de pequena Europa Paraense.

O sucesso de público do Museu Paraense acompanhou os quantitativos de outros Museus brasileiros, bem como dos mundiais, e foram dados demonstrativos do êxito destas Instituições em pleno século XIX.

9 De acordo com Carvalho (1901, p.65), entre 412 e 509 espécimes de animais estavam distribuídos em 129 espécies e mais de 531 espécies de plantas ocupavam o Museu desde a inauguração dos anexos.

10 Os dados relatados estão de acordo com a tabela de freqüência anual dos Museus Paraense, Paulista, Nacional, Paranaense e Júlio de Castilho, entre os anos de 1894 a 1907, divulgada por Lopes (1997, p.300). 
$\mathrm{Na}$ historiografia do Museu Paraense é possível acharmos duas explicações para os grandes quantitativos da freqüência pública: a primeira, relacionada ao crescimento populacional de Belém devido ao boom da borracha que fez a cidade aumentar sua população em 300\% em 34 anos (LOPES, 1997 p.300); e a segunda referente ao incentivo de Goeldi às visitações e o estimulo à simpatia, tanto das coleções, quanto do Horto Botânico e do Jardim Zoológico pelo povo paraense (SANJAD 2005; 2008, p.124-125).

Neste caso achamos importante também inserir, como uma terceira explicação, a própria mudança cultural e intelectual promovida pela Belle-Époque amazônica, sobretudo em Belém. A mentalidade e as práticas sociais dos citadinos mudaram e, nesse contexto, houve uma redefinição do espaço público da cidade, percebida por seus transeuntes, que passaram a visitar locais considerados representativos da intelectualidade européia na época como é o caso do Museu Paraense. Sendo assim, além da função investigativa e instrutiva, o Museu foi claramente um local de entretenimento, por exemplo: devido ao alvoroço dos dias destinados à visitação do público em geral, Goeldi deu às famílias locais a oportunidade visitar o Museu Paraense em um dia destinado particularmente a elas: às terças-feiras, na tentativa de tirá-las do sufoco causado nas quintas-feiras, domingos e feriados, quando iam pessoas de várias condições sociais e diferentes tipos. Longe das "massas" que alcançavam os milhões e dificultavam a diversão familiar, pais e filhos, avós e netos, tios e sobrinhos, poderiam agora se deleitar da agradável "Europa Amazônica" e tudo o que ela poderia lhes oferecer.

Fica claro, portanto, o papel crucial do Parque Zoobotânico tanto na função de entreter, quanto de ensinar; e o estreito laço estabelecido entre o Museu e a sociedade Paraense, a última fosse requerida mais ou menos de acordo com seu comportamento dentro da sua Instituição.

Neste caso, ressaltamos que a idéia de ensino mostrada na abertura dos anexos do Museu Paraense parecia estar basicamente pautada no contato dos visitantes com os objetos da natureza, visto que em nenhum dos documentos até aqui pesquisados Goeldi relatou a necessidade de instrutores para o público. Deste modo, não houve um mediador entre a natureza exposta nas gaiolas, viveiros e hortos e o observador, talvez por acreditarem que a própria natureza poderia dar as respostas necessárias ao observador por meio da sua experiência empírica. Mesmo assim os relatos de governantes como Sodré e Carvalho, aliados as falas de administradores como Veríssimo e Goeldi, demonstram um lugar de destaque destas instituições no ensino público paraense. 


\section{Considerações finais}

As mudanças realizadas a partir da coordenação de Goeldi fizeram do Museu Paraense uma das Instituições mais respeitadas no Brasil da sua época. Transformações promovidas por Goeldi como reflexo do projeto cientificista de Sodré para o Pará, que priorizou a contratação de "homens da ciência" formados em Universidades e demais Institutos de renome em História Natural.

A dinâmica do Jardim Zoológico e do Horto Botânico do Museu ilustrou a maneira de como este estabelecimento efetivou a sua função de ensinar a História Natural no Estado. Visto enquanto um ambiente onde os alunos poderiam ter contato direto com os objetos da natureza, ou seja, as "coisas" do mundo natural o Museu Paraense serviu ao propósito do ensino de ciências no final do século XIX, por estimular a aprendizagem dos organismos e minerais, sobretudo pelo método da lição de coisas.

Na prática a "lição de coisas" representou a teoria de ensino que sustentou a teoria do conhecimento adotada no Museu Paraense. Assim, as coleções foram organizadas de acordo com o método e a ciência de base empirista, buscando suprir todas as dúvidas que pudessem existir a respeito das questões da natureza e seus habitantes. A "regionalização" dos anexos do Museu Paraense refletiu na adoção da fauna e da flora amazônica enquanto instrumentos da educação científica dos visitantes, mesmo que estes estivessem distribuídos em viveiros e bosques de arquitetura em estilo europeu.

Ressaltamos ainda a necessidade de outras pesquisas para entender mais sobre a história do ensino de ciências em Museus de História Natural. Neste sentido, estudos comparativos entre Instituições desta natureza, assumem grande importância na compreensão do seu processo educativo, por possibilitarem a análise das convergências entre elas e o que as difere uma das outras.

Com isso, o presente estudo alia-se às correntes de investigação, que têm se ocupado com o estudo da história do ensino e da difusão das informações científicas em Museus de História Natural, bem como das diferentes práticas e trajetórias na área do colecionismo no Brasil, especialmente na região amazônica; e mostra a contribuição desta análise para outras pesquisas na área, além de servir de suporte teórico para estudos comparativos no âmbito dos Museus de História Natural. 


\section{Referências bibliográficas}

CARVALHO, José Paes de. Mensagem Dirigida ao Congresso do Estado do Pará pelo Dr. José Paes de Carvalho, Governador do Estado, em 15 de abril de 1898, apresentando a proposta de orçamento da Receita e Despesa para o exercício de 1898 -1899. Belém, Typ. Diário Official, 1898.

Relatório Apresentado ao Governador do Estado Exm. Sr. Dr. Augusto Montenegro pelo Dr. José Paes de Carvalho ao deixar a administração em 1을 de Fevereiro de 1901. Belém, Imprensa Oficial, 1901. p.63-66

GOELDI, Emil August. Carta-Circular. Boletim do Museu Paraense de História Natural e Etnografia, Belém, 1(1): 8-10, 1894 .

Relatório sobre o estado do Museu Paraense. Boletim do Museu Paraense de História Natural e Etnografia, Belém, 1(1): 10-20, 1894c.

Relatório apresentado pelo Director do Museu Paraense ao Sr. Dr. Lauro Sodré, Governador do Estado do Pará. Boletim do Museu Paraense de História Natural e Etnografia, Belém, 1(3): 217-239, 1895.

Relatório apresentado pelo director do Museu Paraense ao Sr.Dr. Lauro Sodré, Governador do Estado do Pará. In: Boletim do Museu Paraense de História Natural e Etnographia. Pará, (1897?). p.127 Typographia de Alfredo \& C. Pará.

Relatório apresentado ao Exm. Sr. Dr. Lauro Sodré. Governador do Estado do Pará, pelo Director do Museu Paraense. Boletim do Museu Paraense de História natural e Etnographia, Belém, jun. 2 (3): 257-287, 1898.

REGULAMENTO do Museu Paraense. Boletim do Museu Paraense de História Natural e Etnografia, Belém, 1(1): 22-27, 1894b.

SODRÉ, Lauro. Mensagem dirigida ao Congresso do Estado do Pará pelo Dr. Lauro Sodré, Governador do Estado, ao expirar o seu mandato, no dia 1ำ de fevereiro de 1897. Pará, Diário Oficial, 1897. p.30-36

VERÍSSIMO, José. A Educação Nacional. Porto Alegre: Mercado Aberto, 1985. 
VERÍSSIMO, José. Discurso pronunciado por José Veríssimo, Director Geral da Instrucção Pública, perante o Governador do Estado, CapitãoTenente Bacelar Pinto Guedes, por occasião de se inaugurar o Museu, restaurado em 13 de maio de 1891. Boletim do Museu Paraense de História Natural e Ethnographia, Belém, 1(1): 5-8, 1894.

ALVES, Ana Maria de Alencar. Redutos da Ciência na 'Era dos Museus': Inglaterra, França, Estados Unidos e Brasil. Tese (Doutorado em História Social) - Universidade de São Paulo, 2005a.

ALVES, Jerônimo de Alencar. O Cientificismo da França para a Amazônia. O positivismo de Lauro Sodré. In: José Jerônimo de Alencar Alves. (Org.). Múltiplas faces da história das ciências na Amazônia. 1 ed. Belém: Editora Universidade Federal do Pará, 2005b, v. 1, p. 61-76.

CRISPINO, Luis Carlos Bassalo. As Origens do Museu Paraense Emílio Goeldi: aspectos históricos e iconográficos (1860-1921). Belém: PakaTatu, 2006.

DANTES, Maria Amélia (Org). Espaços da Ciência no Brasil: 1800-1930. - Rio de Janeiro: Editora Fiocruz, 2001. p.13-22.

GARCÍA, Susana V. Museos Escolares, Colecciones y La Enseñanza Elemental de lãs Ciências Naturales en la Argentina de fines del Siglo XIX. História, Ciências, Saúde - Manguinhos, Rio de Janeiro, v.14, n.1, p.173-196, jan-mar. 2007.

GUALTIERI, Regina CândidaEllero. AAmazôniasob Olhares Evolucionistas: a ciência no Museu Paraense (1894-1914). In: ALVES, José Jerônimo de Alencar (org.). Múltiplas Faces da História das Ciências na Amazônia. Belém: UFPA, 2005, p. 103-134.

LOPES, Maria Margaret. O Brasil Descobre a Pesquisa Científica. Os Museus e as Ciências Naturais no século XIX. São Paulo, Hucitec, 1997.

MACHADO, Diego. A "LIÇÃO DE COISAS": O Museu Paraense e o ensino da História Natural (1889-1900). Dissertação (Mestrado) - Universidade Federal do Pará, Instituto de Educação Matemática e Científica, Programa de Pós-Graduação em Educação em Ciências e Matemática, Belém, 2010. 
SANJAD, Nelson. A Coruja de Minerva: o Museu Paraense entre o Império e a República, 1866-1907. Tese (Doutorado em História das Ciências). Fundação Oswaldo Cruz - Rio de Janeiro, 2005.

SANJAD, Nelson. A Revitalização do Parque Zoobotânico do Museu Goeldi: em busca de uma nova relação com o público. Revista Museologia e Patrimônio, v. 1, p. 123-127, 2008.

SARGES, Maria de Nazaré. Belém: Riquezas produzindo a Belle-époque (1870-1912) - Belém: Paka-Tatu, 2002, 2.ed.

VALDEMARIN, Vera Teresa. Estudando as Lições de Coisas: análise dos fundamentos filosóficos do Método de Ensino Intuitivo - Campinas, São Paulo: Autores Associados, 2004. - (Coleção educação contemporânea).

VALDEMARIN, Vera Teresa. O Método Intuitivo: os sentidos como janelas e portas que se abrem para um mundo interpretado. In: ALMEIDA, José Soares de; SAVIANI, Demerval; SOUZA, Rosa Fátima de e VALDEMARIN, Vera VALDEMARIN, Vera Teresa. O legado educacional do século XIX. Campinas: Autores Associados, 2006.

VERGARA, Moema de Rezende. Ensaio sobre o termo "Vulgarização Científica" no Brasil do Século XIX. Revista Brasileira de História da Ciência, Rio de Janeiro,v.1, n.2, p. 137-145, jul/dez, 2008.

ZAMBONI, Lilian Márcia Simões. Cientistas, Jornalistas e a Difusão Científica: subjetividade e heterogeneidade no discurso da difusão científica - Campinas, SP: Autores Associados, 2001. 
18.

\section{O Museu Nacional na Exposição Universal de Paris em 1889}

\section{As "Festas do Progresso"}

As Exposições Universais da segunda metade do século XIX são aqui analisadas como eventos que tiverem como objetivo festejar as conquistas da civilização e arrolar as realizações da indústria humana. Esses espetáculos tiveram início pela prática francesa de impulsionar, a cada cinco anos, uma exposição nacional a partir de 1798.

Outra tradição, iniciada em 1851 na Inglaterra, também desencadeou as mostras agrupando-as e proporcionando disputa de premiações a partir da exposição de atividades humanas (VAINFAS, 2002, p. 252)..

Com vistas aos estudos sobre a temática, algumas obras são referências para a análise sobre as grandes exposições, com este propósito, destacamos o livro do historiador francês, Pascal Ory (1989). A obra foi elaborada, dentre outras, motivada pela ideia de comemorar o bicentenário da Exposição Universal de Paris em 1889, evento que acabou não acontecendo. (BARBUY, 1999, p. 23).

Ory, em seu primeiro capítulo intitulado Festa do Progresso, visando esclarecer o caráter universal das exposições, desenvolve abordagens contendo questões históricas, econômicas e políticas associadas aos produtos industriais e das belas artes. $O$ mesmo autor esclarece que Londres foi o país pioneiro em adotar o livre comércio e também o primeiro a realizar uma exposição de caráter universal, em 1851, porém reforça que a exposição francesa "em 1889, se chamará mais precisamente exposição universal internacional". (ORY, 1989, p. 9). 
Cabe ressaltar que, a partir da Exposição de Londres, foram realizados outros eventos de caráter universal ao longo da segunda metade do século XIX: Paris, 1855; Londres, 1862; Paris, 1867; Viena, 1873; Filadélfia, 1876; Amsterdan, 1883; Antuérpia, 1885; Paris, 1889; Chicago, 1893 e Paris 1900.

A historiografia brasileira, em relação às Exposições Universais a partir dos anos 80 do século XX, vem apresentando pesquisas nessa temática envolvendo questões como o progresso, destacando a modernidade e, consequentemente, a industrialização.

Maria Margaret Lopes (2001, p. 181) apresenta, em sua discussão sobre as exposições em geral, o progresso aparecendo como ideal comum entre as nações participantes, porém a autora destaca as diferenças inconfundiveis de algumas nações participantes. Diante deste pressuposto, os povos eram tidos como iguais e suas características passavam a ter propósito a partir do mesmo ideal de progresso ou da busca pela "civilização":

\begin{abstract}
E, se nesta escala comum constituída por valores tidos como universais tais como progresso e civilização, verificam-se algumas dissonâncias, estas são facilmente explicáveis pelo que era tido como seu ritmo mais lento de algumas nações em relação às demais, seu atraso, quase sempre relacionado discursivamente ao grau de barbárie definido por um padrão radicalmente etnocêntrico. (LOPES, 2001, p. 181).
\end{abstract}

As Grandes Exposições do século XIX podem ser consideradas como um empreendimento para a divulgação científica, equiparadas aos periódicos, aos congressos, aos museus, entre outros, "visando colocar a ciência ao alcance de todos." (HEIZER, 2001, p. 166).

As obras estudadas na pesquisa sobre as Exposições Universais versam sobre diferentes análises com enfoques específicos por países, com abordagens de distintas naturezas, como por exemplo, aspectos econômicos, políticos, arquitetônicos, culturais, museográficos, entre outros.

Em relação à historiografia brasileira, nos apropriamos da preciosa análise existente no primeiro capítulo da tese de Alda Heizer (2005) de título "Imagens do Progresso" (2005, p. 15-38). Para nossa pesquisa, utilizamos os autores elencados por Heizer que formam as referências nacionais sobre a temática.

Ao estudarmos a vasta bibliografia especializada nesses eventos chamados universais, identificamos uma discreta análise científica em 
relação à participação brasileira, por isso, acreditamos ser necessária a realização de estudos sobre o envolvimento do Museu Nacional em um dos eventos universais destacando uma abordagem científica.

Nesse momento, vale sublinhar o interesse de Maria Amélia Dantes em fortalecer a relevância da História das Instituições para a historiografia das ciências no Brasil.

\begin{abstract}
A história institucional, tradicionalmente inserida na linha externalista da História da Ciência tem recebido um destaque especial na nova historiografia, já que as formas organizacionais passaram a ser vistas como indissociáveis dos desenvolvimentos conceituais das ciências. [...] A história institucional brasileira está assim perfeitamente integrada às tendências historiográficas do momento. E as instituições imperiais têm recebido uma atenção especial. (DANTES, 2001, p. 230-231).
\end{abstract}

Para exemplificar o crescente interesse sobre as exposições como tema de pesquisa, identificamos a obra International Exhibitions, Expositions Universelles and World's Fairs, 1851-2005: A Bibliography, publicada em 2000, atualizada 2002 e completada 2006, apresentando o total de 1869 citações (livros, capítulos de livros, teses, artigos em periódicos) sobre as exposições realizadas em 24 países (GEPPERT, COFFEY, LAU, 2006, p. 33-41), um rico catálogo para pesquisas.

\title{
A Exposição Universal de Paris em 1889
}

Um dos trabalhos que nos auxilia a dar uma ideia da organização do evento francês é o Rapport General, constituído de dez volumes que tratam da Exposição de 1889. Seu autor, o engenheiro Alfred Picard, iniciou o primeiro volume com um histórico sumário sobre as exposições universais francesas de 1798 a 1849, com forte objetivo de contribuir para a história das exposições francesas. A publicação é uma fonte relevante para acompanhar desde os estudos preliminares iniciados em 1884 até a relação de receitas e despesas computadas em 1892.

O Decreto de 8 de novembro de 1884, registrado no Rapport Général, instituiu a exposição com antecedência de quase cinco anos :

Art.1 Uma Exposição Universal de produtos industriais será inaugurada em Paris em 5 de maio de 1889 e será encerrada em 31 de outubro do mesmo 
ano. Art.2 Um decreto posterior determinará as condições em que será realizada a Exposição Universal, o regime em que serão colocadas as mercadorias expostas e os diversos gêneros de produtos suscetíveis de serem admitidos. Art. 3 O Ministro do Comércio é o responsável em executar o presente decreto. (RAPPORT GÉNÉRAL, 1889, p. 3).

O papel do Estado na exposição também é enfatizado no artigo de Xavier Ryckelynck (1989). O autor analisou a trajetória de Alfred Picard enfatizando o seu papel de funcionário do Estado francês e, apresentou, consequentemente, a intenção da máquina francesa em selecionar um engenheiro com credibilidade e competência para a organização das exposições universais (RYCKELYNCK, 1989, p. 26).

Madeleine Rebérioux já havia apontado a determinação do poder público em identificar perfis para atuarem como organizadores de toda a documentação oficial e da divulgação das exposições (REBÉRIOUX, 1979, p. 5-7 Apud BARBUY, 1999, p. 25).

Um trabalho que merece destaque em nossa pesquisa é a dissertação de Heloísa Barbuy (1999), pois apresenta sua abordagem da exposição como fenômeno visual. A partir de seus estudos, em especial, iconográficos, a autora proporciona em seus detalhes uma visão panorâmica da exposição francesa que nos auxilia de maneira determinante.

Para marcar arquitetonicamente o espetáculo do progresso de 1889, semelhante ao primeiro evento londrino (Palácio de Cristal em 1851), foi elaborada a construção de um símbolo somente para fortalecer o ideal de modernidade três anos antes do início do evento. Para isto, foi edificada a Torre Eiffel, construída pelo engenheiro francês Alexandre Gustave Eiffel.

Homem-símbolo de sua época, Eiffel foi o protótipo da audácia da engenharia da fin de siécle [do fim do século]. Expert [perito] na construção em ferro, trazia em seu curriculum diversas realizações que the haviam rendido notoriedade. Prestigiado pelo regime, a proposta de Eiffel foi a vencedora no concurso realizado pelo governo francês com o objetivo de erguer um monumento para a exposição do centenário. (LEMOINE, 1986 apud PESAVENTO, 1997, p. 184). 
O local previsto para o certame tinha ao todo setenta hectares que incluíam o Palácio, o Jardim de Trocadero, Quai d'Orsay, L'Avenue du Suffren, Ministère dês Affaires Étrangers e L'Esplanades des Invalides e o Campo de Marte tendo a torre como atração máxima (SCHWARCZ, 1998, p. 400). A Torre Eiffel virou o fetiche para os visitantes da mostra e, ao longo dos anos, dos visitantes de Paris (e isso acontece até os dias de hoje).

Heloisa Barbuy aborda os estudos de Anne Rasmussen (1992, apud BARBUY, 1999, p. 41-43) somados ao de Ory Pascal, sobre as classificações nas exposições como regulamentações aos expositores determinando divisões por classes e grupos, catalogando os produtos por categorias.

Tais classificações dizem respeito às categorias de produtos brutos e indústrias extrativas (como ferro e metalurgia), manufaturados (como tecidos, roupas e móveis), de indústrias em geral (como a mecânica, a elétrica), de obras de arte e a outras categorias de gênero, conforme as particularidades de cada exposição (a categoria de produtos agrícolas surge em 1867, a de atividades de ensino técnico, em 1878, a de "economia social", em 1889). [...] ○ que fica evidenciado no trabalho de Rasmussen é que mudam as formas de classificar, mas nunca se abandona o princípio da classificação [...] (BARBUY, 1999, p. 43)

As classificações foram sendo atualizadas a cada exposição e esses regulamentos eram distribuídos antecipadamente para os países participantes, o que os tornam preciosos para a análise das especificidades de cada evento.

A mostra francesa de 1889 contou com dez grupos incluindo o de Economia Social, assim divididos: Grupo I. Obras de Arte (classes 1-5); Grupo II. Educação e ensino, material e procedimentos das artes liberais (classes 6-16); Grupo III. Mobiliário e Acessórios (classes 17-29); Grupo IV. Tecidos, vestimentas e acessórios (classes 30-40); Grupo V. Indústrias Extrativas, produtos brutos e manufaturados (classes 41-47); Grupo VI. Aparelhagem e procedimentos das indústrias mecânicas, eletricidade (classes 48-66); Grupo VII. Produtos Alimentares (classes 67-73); Grupo VIII. Agricultura, vinicultura e piscicultura (classes 73-77); Grupo IX. Horticultura (classes 78-83) e Grupo de Economia Social (16 itens), este último grupo criado para a mostra francesa. (BARBUY, 1999, Anexo 2). 
Heizer analisou o significado da Exposição de Paris de 1889, como uma das festas da República, e a inauguração da Torre Eiffel e da Galeria Monumental das Máquinas como símbolos que se tornaram a síntese do sucesso da civilização francesa. "Segundo os seus organizadores, esta síntese poderia ser traduzida pelo tripé república, Ciência e Técnica: os grandes protagonistas da festa." (HEIZER, 2005, p. 47).

\section{O Museu Nacional na Exposição de Paris em 1889}

Ao situarmos o Museu Nacional no contexto do Brasil, partimos da chegada da Corte Portuguesa ao Brasil que marcou e transformou a Cidade de São Sebastião do Rio de Janeiro na capital da monarquia portuguesa. Como conseqüências, foram recriadas as principais instituições régias e fundados estabelecimentos, tais como: a Academia de Marinha; a da Artilharia e Fortificação; o Arquivo Militar; a Casa da Pólvora; o Teatro São João; a Imprensa Régia; o Jardim Botânico; a Academia de Belas-Artes; a Junta do Comércio; a Biblioteca Real, entre outros. O Rio de Janeiro converteu-se em um palco de um processo civilizatório que Maria Odila da S. Dias denominou "interiorização da metrópole" (VAINFAS, 2002, pp. 701-703). Nesse cenário, em 6 de junho de 1818, por decreto de d. João VI (1767-1826) e execução do ministro do Reino, Thomas Antonio de Villanova Portugal, foi criado o Museu Real - atual Museu Nacional.

Assim, o Museu Real foi criado para ser um Museu Metropolitano, como apontou Maria Margaret Lopes (LOPES, 1997, p. 47), um núcleo para o recebimento e catalogação das riquezas naturais das províncias brasileiras, que, por meio de intercâmbio com outras nações, foi enriquecido com coleções de âmbito universal.

Durante o período joanino, as coleções do Museu Real sofreram ampliações e, após a passagem do reino brasileiro para o império, com D. Pedro I e a devida orientação de seu ministro, José Bonifácio de Andrada e Silva, foi intensificada uma política de estímulo aos viajantes naturalistas, para doarem ao Museu o resultado de suas coletas (artefatos e espécies dos diferentes locais do Brasil) (LACERDA, 1905, p. 12).

O Governo Imperial, no desempenho da exploração das riquezas naturais ainda desconhecidas, e posteriormente com D. Pedro II ${ }^{1}$ no constante incentivo aos estudos científicos, fortaleceu o desenvolvimento das ciências no Brasil ao longo da segunda metade do século XIX.

1 Sobre seus interesses e incentivos, ver publicação do Arquivo Nacional (ARQUIVO NACIONAL, 1977). 
O Museu Nacional, com suas áreas do conhecimento - a antropologia, a botânica, a zoologia, a mineralogia e paleontologia - proporcionou a realização de estudos que contribuíram para o enriquecimento das ciências naturais, que, na segunda metade do século XIX, eram saudadas como as responsáveis pelo progresso do país.

O Brasil se fez representar nas "arenas pacíficas" a partir da segunda exposição universal realizada em Londres em 1862 e, durante o Segundo Reinado, a partir de 1861, foram realizadas mostras nacionais com vistas a preparar o país para a participação nas exposições universais. (VAINFAS, 2002, p. 252). Além disso, a instituição científica fez parte de algumas das chamadas Exposições Universais, como as de Londres (1862), Paris (1867), Viena (1873), Filadélfia (1876), Antuérpia (1885) e Paris (1889), ao longo da segunda metade do século XIX.

Dentre as exposições citadas, a Exposição Universal realizada em Paris no ano de 1889, inaugurada em 5 de maio, despertou nosso interesse por ter se tratado de um evento comemorativo ao centenário da Revolução Francesa, idealizada para enaltecer a república, considerada dentre as exposições como a mais histórica, e por ter contado com a última participação do império brasileiro.

Para a realização da pesquisa está sendo necessário utilizar variadas fontes em diferentes instituições. Inclusive, no próprio Museu Nacional está guardado o maior acervo documental sobre a instituição e, para a realização da pesquisa, o acervo museográfico - os objetos que estão sendo selecionados e problematizados devido a participação do museu na mostra francesa.

Ainda em relação à pesquisa documental que está sendo realizada, o periódico Auxiliador da Indústria NacionaR é o material mais completo para acompanhar a participação do Império do Brasil nas Exposições Universais da segunda metade do século XIX (HEIZER, 2005).

A partir da constatação da existência de dois espaços utilizados pelo Império brasileiro na exposição de 1889 - o Pavilhão Brasileiro e a Casa Inca - a pesquisa foi sendo direcionada para a participação do Museu Nacional nestes dois locais. A dissertação de Heloísa Barbuy (1999) foi imprescindivel para o entendimento espacial da participação brasileira no certame.

2 Criado como órgão da Sociedade Auxiliadora da Indústria Nacional/SAIN em 1833 (WERNECK, 1979 apud HEIZER, 2005, p. 81) 
A análise dos documentos existentes na Seção de Memória e Arquivo do Museu Nacional/UFRJ, tais como ofícios, avisos, atas e os relatórios existentes, associados às narrativas detalhadas do periódico Auxiliador da Indústria Nacional (1888, 1889 e 1890) e o Catálogo da Exposição Universal de Paris em 1889, foi possível levantar um vasto material sobre a participação da instituição na exposição em questão.

Analisando as Atas do Conselho Deliberativo do museu, por exemplo, podemos acompanhar as solicitações de diárias e verbas para as despesas do Diretor Ladislau Netto durante os meses em que esteve na França para acompanhar a montagem do evento. $\mathrm{O}$ empenho de Ladislau em Paris foi tão expressivo e proporcionou a publicação de seu Relatório do ano de 1889, transformado em livro pela Libraire Ch. Delagrave (Netto, 1889).

Com vistas ao nosso estudo, realizamos articulação entre os objetos existentes nas coleções da instituição (incluindo a relação do material existentes no cofre da direção da instituição), somados às imagens fotográficas guardadas no Instituto Histórico Geográfico Brasileiro e aos catálogos para a identificação dos objetos do Museu Nacional que participaram da exposição francesa.

Podemos adiantar que três categorias de objetos foram identificadas: antropologia (etnografia indígena), botânica e mineralogia. $O$ procedimento seguinte foi analisar o material como artefatos científicos, identificando as respectivas pesquisas que estavam sendo realizadas na instituição.

No que diz respeito aos artefatos indígenas expostos na Casa Inca sob a coordenação de Ladislau Netto, a pesquisa aponta que parte do material foi utilizado em exposições anteriores (nacionais e estrangeiras), como por exemplo, a exposição antropológica de 1882 (realizada no Museu Nacional), a exposição da Antuérpia realizada em 1885 e a de Berlim em 1888.

\section{Considerações Parciais}

$\mathrm{Na}$ apresentação deste recorte da pesquisa, não coube apresentar a contextualização histórica que permeia o período estudado nem a determinação de sua delimitação temporal. O propósito foi refletir sobre o estudo que vem sendo realizado da participação do Museu Nacional na Exposição Universal de Paris em 1889, como instituição brasileira relevante para o desenvolvimento científico do Brasil na segunda metade do século XIX. 
Nesta perspectiva, a articulação de ofícios, atas, correspondências, periódicos (relatórios, revistas e jornais), objetos que participaram da mostra, diplomas e medalhas de premiação, entre outros, estão nos auxiliando na apresentação do Museu Nacional como um núcleo de desenvolvimento de pesquisas científicas do país apresentadas naquele certame.

Para este desafio, acrescentamos a importância da utilização de catálogos e guias do evento como fontes que orientam a problematização dos objetos em exposições. A disposição e a determinação em identificar os objetos em diferentes documentos, e a busca nas coleções dos departamentos da instituição são atividades de investigação que selam o papel do pesquisador e fortalecem o ineditismo do presente trabalho.

O caminho que estamos percorrendo demonstra que o Museu Nacional, a partir de suas áreas do conhecimento e ao longo da segunda metade do século XIX, teve sua parcela de contribuição na realização de pesquisas e na representação do país nas exposições como lugares de ciências. 


\section{Referências bibliográficas}

BARBUY, Heloísa. A Exposição Universal de 1889 em Paris. São Paulo: Edições Loyola, 1999.

DANTES, Maria Amélia. As instituições imperiais na historiografia das ciências no Brasil. In: Ciência, Civilização e Império nos Trópicos. (orgs.) Alda Heizer \& Antonio Augusto Passos Videira. Rio de Janeiro: Acces, 2001.

GEPPERT, Alexander C.T.; COFFEY, Jean and LAU, Tammy, Internationl Exhibitions, Expositions Universelles and World's Fairs, 1851-2005. Editions: Freie Universität Berlin, Germany; California State University, Fresno, USA, 2006.

HEIZER, Alda. Os Instrumentos Científicos e as Grandes Exposições do século XIX. In: Ciência, Civilização e Império nos Trópicos. [org. Alda Heizer e Antonio Augusto Passos Videira]. Rio de Janeiro: Access, 2001.

HEIZER, Alda. Observar o Céu e medir a Terra: Instrumentos Científicos e a participação do Império do Brasil na Exposição de Paris de 1889. São Paulo: 2005. Tese (Doutorado em Ciências) - Universidade Estadual de Campinas.

LACERDA, João Baptista de. Fastos do Museu Nacional do Rio de Janeiro. Rio de Janeiro: Imprensa Nacional, 1905.

LOPES, Maria Margaret. O Brasil descobre a pesquisa científica: os museus e as ciências naturais no século XIX. São Paulo: Ed. HUCITEC, 1997.

O local musealizado em Nacional - aspectos da cultura das ciências naturais no século XIX, no Brasil. In: Ciência, Civilização e Império nos Trópicos. [org. Alda Heizer e Antonio Augusto Passos Videira]. Rio de Janeiro: Access, 2001.

NETTO, Ladislau. Le Muséum National de Rio de Janeiro et son influence sur les Sciences Naturelles au Brésil. Paris: Librairie. Ch. Delagrave, 1889.

ORY, PASCAL. L'Expo Universelle, 1889. La memoire des siècle. Paris: Editions Complexe, 1989. 
PESAVENTO, Sandra Jatahy. As exposições universais. Espetáculos da modernidade do século XIX. São Paulo: Hucitec, 1997.

RAPPORT GÉNÉRAL. Exposition Universelle Internationale de 1889. (org.) Alfred Picard. Paris: Imprimerie Nationale, 10 vol., 1889.

RYCKELYNCK, Xavier. Les hommes de l'Exposition Universelle de 1889: Le cãs Alfred Picard. Le Mouvement Social.No. 149, Mise em Scène ET Vulgarisation: L'Exposition Universelle de 1889. Out-Dez 1989. P. 25-42.

SCHWARCZ, Lilia Moritz. As barbas do imperador: D. Pedro II, um monarca nos trópicos. São Paulo: Companhia das Letras, 1998.

VAINFAS, Ronaldo. Dicionário do Brasil Imperial (1822-1889) / Ronaldo Vainfas (org). Rio de Janeiro: Objetiva, 2002. 


\title{
19.
}

\section{"Certamen Agricola, Industrial e de Manufaturas": o aparecimento do Novo Século e a participação de Sergipe nas exposições nacionais}

\author{
Fabrícia de Oliveira Santos ${ }^{1}$ \\ Alexandrina Luz Conceição ${ }^{2}$
}

\begin{abstract}
Manifestações primeiras da industrialização triunfante, em meados do século XIX, as grandes exposições tornaram-se espelho da sua própria época, ao adaptarem-se à evolução sócio-geopolítica da humanidade em mutação permanente. Assim, a sua história reflete, de forma irrefutável, o devir geopolítico dos últimos 150 anos. Apresentando- se como manifestações de prestígio, senão de ostentação, onde as nações pretendem afirmar e/ou consolidar o seu próprio poder econômico, procuram exaltar a fé na ciência e na técnica e a aspiração ao progresso. Revelam-se como testemunhos fidedignos da evolução do saber e da atividade humana (VERÍSSIMO, 1998, p. 31).
\end{abstract}

As Exposições Universais, ocorridas entre 1851 e 1908 na Europa e na América do Norte, são consideradas eventos peculiares na consolidação da burguesia, ícones da modernidade, das novas tecnologias e das

1 Doutoranda em Geografia do Núcleo de Pós-Graduação em Geografia da Universidade Federal de Sergipe (NPGEO/UFS). Professora do Curso de Bacharelado em Arqueologia e Conservação de Arte Rupestre (UFPI/CCN/Arqueologia).

E-mail: fabriciaseagmail.com

2 Profa. Visitante do Núcleo de Pós-Graduação em Geografia da Universidade Federal de Sergipe - NPGEO/UFS. Coordenadora do Grupo de Pesquisa Estado, Capital, Trabalho e as Políticas de Re-ordenamentos Territoriais (CNPq/UFS).

E-mail: aluz@oi.com.br 
pesquisas científicas vigentes no período. Sergipe, do que se tem notícia, não teria participado dessas mostras. Mas, a realização de uma exposição local entre 1899 e 1900, no "aparecimento do novo século", conforme o "Programa e Regulamento da Exposição Commemorativa Sergipana em Aracaju - Certamen Agricola, Industrial e de Manufaturas", documento impresso de $1899^{3}$, indica a sua inserção no mundo das exposições, em tempo que o acervo exibido em Aracaju, ao finalizar a mostra, seria enviado para a "Exposição Permanente do Museu Comercial da Filadélfia", nos Estados Unidos. Outras referências à participação sergipana nesses "certamens" estão registradas em edições da Revista Agrícola de 1905 a 1908, referindo-se ao convite recebido, aos objetivos para o comparecimento e a descrição dos produtos enviados para serem expostos na Capital Federal, Rio de Janeiro, na ocasião de "comemoração do centenário de abertura dos portos brasileiros ao comércio internacional".

\title{
As exposições e sua divulgação
}

(...) os museus e a imaginação museologizante são profundamente políticos (ANDERSON, 2008, p. 246)

As exposições, mesmo que de curta duração, possuem e/ou formam acervos, e levam a comunicação de algo, apesar de não cumprirem, obrigatoriamente, a salvaguarda dos mesmos, e estão imbuídas de um discurso sobre o que se expõe:

\begin{abstract}
Os museus apresentam sempre uma coleção que, ao ordenar e dar sentido a seus conteúdos constrói uma narrativa. Os museus realizam uma transformação simbólica. Os objetos retirados de seu contexto original se tornam obras de arte, relíquias, artefatos. Objetos concretos do mundo transitório, da vida cotidiana, passam a representar valores abstratos - a nação, a evolução da espécie, a indústria, a imigração, a cidade (OLIVEIRA, 2008, p. 148).
\end{abstract}

Os objetos utilizados em exposições, se pertencentes ou não a museus, são concebidos não apenas como objetos funcionais, além de sua natureza e função, mas como objetos históricos, "de ordem ideológica e não cognitiva (...) que dizem respeito à dinâmica na vida das

3 O documento integra o acervo da Documentação Sergipana da Biblioteca Pública Epifânio Dória, Aracaju, Sergipe. 
sociedades" (MENESES, p. 27-28), e as exposições são concebidas como discurso - "pressupõe a articulação de enunciados sobre certos problemas humanos, desenvolvidos com o suporte das coisas materiais" (MENESES, p. 46) e com especificidades próprias e, como linguagem museológica, os discursos das exposições são essencialmente espaciais e visuais, e não simples variações ou adaptações da linguagem verbal. Contudo, observa-se "um lamentável deslocamento de papéis: o que deveria ser 'dito' com os objetos passa à responsabilidade das legendas e outros recursos" (MENESES, 2005, p. 47).

Para as referências às exposições examinadas neste artigo, as abordagens museológicas contemporâneas podem ser anacrônicas, uma vez que "a exposição, principalmente no século XIX, sempre esteve ajustada aos estágios mais avançados das ciências" (MENESES, 2005, p. 33) e na maioria das vezes, "convencionais" (organização de objetos para produção de sentido, ou "meramente taxonômicas, classificatórias numismática, porcelanas, mobiliário, armaria etc." (MENESES, 2005, p. 35). Entretanto, como não é possível para o momento acessar os objetos expostos nas mostras realizadas (1899 e 1908) para uma análise atual do seu discurso expositivo, o artigo foca apenas indícios sobre as exposições em impressos. Possibilidade destacada por Barbuy (1996) ao analisar a divulgação da participação do Brasil na Exposição Universal de 1889 em Paris, através de impressos produzidos para/sobre esta mostra.

Recorrer aos impressos como fontes de acesso às exposições justificase por considerá-los também, ao lado das mostras, como produções de uma nova visão de mundo que se irradia na esteira das mudanças operadas na política na segunda metade do século XIX, cujo papel da imprensa contribui para mudanças de representações sobre/para o Brasil, a partir, sobretudo da modernização de suas capitais, como o Rio de Janeiro na luta contra os "velhos hábitos coloniais" (SEVCENKO, 2003, p. 46).

O texto em pauta compulsa um programa para a organização de exposição na cidade de Aracaju, conforme padrões estabelecidos em "certamens" semelhantes, e notícias em uma revista - gênero que se constituía também em grande novidade à época (MARTINS, 2008).

De acordo com Santos e Costa (2006, p. 348):

Os governos dos países convidados, juntamente com os setores empresariais de vários ramos da atividade econômica, enviavam amostras de produtos, visando a realizar algum tipo de publicidade ou efetivar negócios. Lembremos que data do final do 
século XIX o nascimento da publicidade através dos jornais, revistas e outros meios de comunicação de massa. Jornais, folhetos, livros organizados (como o Le Brésil para a Exposição de Paris em 1889), entre outros meios de propaganda, foram utilizados pelas Comissões que representavam o Brasil como uma forma de divulgação das matérias- primas, potencialidades naturais e da incipiente "indústria" do pais, para os investidores e mercados externos, e, também, para o imigrante estrangeiro.

Desta forma, os impressos podem ser considerados como um dos propagadores do discurso das exposições, que é o discurso da classe dominante que ansiava por uma produção unificada de uma linguagem através da reprodutibilidade garantida pela imprensa. Anderson (2008, p. 80) aponta a imprensa como o embrião das comunidades imaginadas proporcionadas a partir de um capitalismo tipográfico ${ }^{4}$, através da imprensa, criou campos unificados de intercâmbio e comunicação. As exposições, por sua vez, produzem também uma linguagem através dos objetos e demais itens em exposição, mas que necessitam de ampla divulgação impressa como forma de sedimentar um discurso ${ }^{5}$. Assim, exposições e imprensa, unidos para a produção de uma linguagem (a troca social de vocabulário em um lócus, aqui, os impressos) que unifica uma imagem para o campo.

\section{O “Programa e Regulamento da Exposição Commemorativa Sergipana em Aracaju - Certamen Agricola, Industrial e de Manufaturas"}

Uma pequena publicação impressa de cerca de $15 \times 10 \mathrm{~cm}$, datada de 1899 (Figuras 1 e 2), aborda, em suas vinte e quatro páginas, o seguinte conteúdo: capa, texto introdutório convidativo à mostra, Ato do Poder Executivo que aprova o programa e instruções da exposição, a distribuição das seções, as instruções regulamentares e modelo de folha para expedição dos produtos.

4 Capitalismo e imprensa criaram públicos leitores de massa monoglotas, apesar de não haver a possibilidade de uma unificação lingüística geral da humanidade, mas o capitalismo editorial conseguiu montar vernáculos aparentados criando línguas impressas, reproduzidas mecanicamente (ANDERSON, 2008, p. 78-79).

5 O conceito de discurso é aqui entendido como uma enunciação de outrem unida a um contexto por relações dinâmicas, complexas e tensas (BAKHTIN, 1997). 


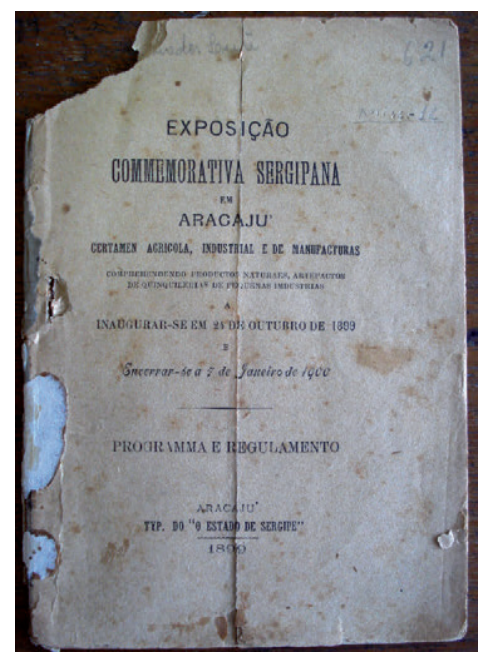

Fig 1 - Capa do Programa

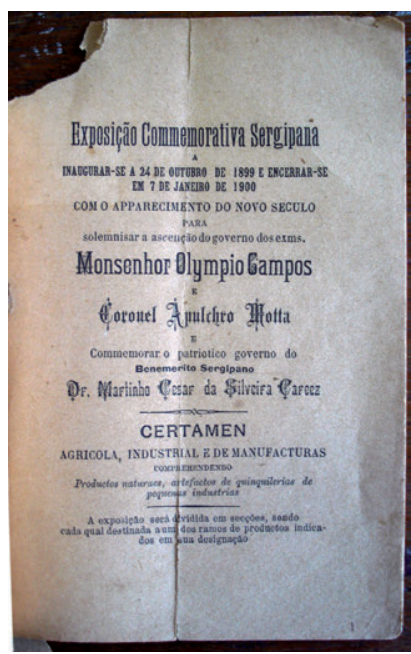

Fig 2 - Capa da distribuição das Seções

O texto que abre o referido programa, diante o seu conteúdo, teria sido enviado para os expositores do evento. O Programa foi elaborado em agosto de 1899, com a inauguração prevista para 24 de outubro do mesmo ano e duração até 07 de janeiro de 1900:

Attento a necessidade da boa organisação e indispensável distribuição das seções respectivas da Exposição que tem de ser inaugurada nesta capital e figurar na cidade de Phyladelphia, tenho a subida honra de dirigir-me a V. S. confiado no vosso amor as industrias e progresso do Estado, como no seu acrysolado patriotismo, de enviar de enviar o mais breve possível os productos que pretender expor, ou dar aviso com antecedência do espaço que requisitar para os mesmos.

Esperando que com o vosso concurso maior brilhantismo advirá para honrar nosso Estado, tenho a subida honra de subscrever-me.

D V. S.

Attento venerador

Alcibiades Leite

Comissario do Governo (EXPOSIÇÃO, 1899, p. 3) 
No texto depreende-se o destaque veemente do convite à participação daqueles com "amor a indústria e ao progresso do Estado". Indica a possibilidade da inserção do estado de Sergipe nas exposições internacionais no âmbito da espacialização do capital (HARVEY, 2006), e indícios de um "capitalismo tipográfico"6 (ANDERSON, 2008) neste processo, e a recorrência das exposições como parte do vocabulário que referendam o signo (BAKTHIN, 1997) do progresso associado à agricultura sergipana de modo que, assim como para o Brasil, participar das exposições e organizá-las é um instrumento de convencimento das próprias elites do que para a cooptação dos trabalhadores (PESAVENTO, 1997, p. 71). No contexto analisado, a agricultura, a sua modernização seria a condição para estabelecer a indústria e os caminhos do progresso técnico.

A segunda metade do século XIX inaugura, a partir da Europa, o desejo de um mundo unificado com a expansão do capitalismo industrial que alteraria a representação das fronteiras, fato proporcionado, sobretudo, pelos avanços das comunicações, do comércio internacional, e dos "exploradores"7. Porém, a unidade prescindia a rivalidade entre nações consideradas desenvolvidas economicamente: "a unidade do mundo implicava a sua divisão. O sistema mundial do capitalismo era uma estrutura de 'economias nacionais' rivais" (HOBSBAWM, p. 113). Nessa contradição unificação versus rivalidade de disputa de mercados emergem mecanismos de síntese de mercadorias e serviços, entre eles as exposições, que figuram como um

Catálogo de conhecimento humano acumulado, síntese de todas as regiões e épocas, a exposição funcionava para seus visitantes como uma 'janela para o mundo'. Ela(s) exibiam o novo, o exótico, o desconhecido, o fantástico, o longíquo.

Nelas se exibiam as mais complexas máquinas, os mais recentes inventos, classificados cuidadosamente e organizados segundo preocupação didática e enciclopédica (...) Apresentando um verdadeiro engenho humano de seu tempo, as exposições teriam a função didático-pedagógica de instruir os visitantes, prestando-lhes as mais diversas informações sobre os objetos expostos. (PESAVENTO, 1997, p. 45)

6 Ver, também, Hobsbawm, 2010, p. 104-105.

7 De acordo com Hobsbawm (2010, p. 91-92): "homens que abriram o planeta ao conhecimento. Eram os que viajavam em áreas onde o desenvolvimento do econômico do lucro ainda eram insuficientemente atraentes para fazer substituir o 'explorador' pelo 'comerciante' (europeu) (...)". Ver, também, Pratt (1999, p. 69). 
Os objetivos da exposição de 1899 em Sergipe estavam arraigados ao modelo inicial das exposições burguesas, sobretudo no que diz respeito à classificação dos objetos e demais itens com a finalidade de integração de Sergipe à modernidade. A ideia do deslocamento do acervo compor uma mostra permanente no Museu Comercial da Filadelfia significava, nas palavras do Poder Executivo,

[...] o Presidente do Estado, tendo em consideração as grandes vantagens que para as industrias e progresso do trabalho e estimulo do cidadão resultam dos concursos estabelecidos pelas exposições e pre-julgamento das producções da actividade individual, que concorrendo, a estes certamens, ou por ellas reconhecendo o grande desenvolvimento das industrias fabril e agricolas, as artes e manufacturas, das sciencias e da instrucção do povo, mais activa e impulsiona o estimulo para o aperfeiçoamento e educação do trabalho e da intelligencia do cidadão;

E tomando consideração a necessidade de corresponder ao appelo dirigido a este Estado para apresentar o esforço, actividade e progresso de seu povo perante o estrangeiro, enviando todos os productos naturaes do nosso ubérrimo solo e seus artefactos e productos industriaes para figurarem na EXPOSIÇÃO PERMANENTE DE PHILADELPHIA, concurso em que figurarão todos os Estados da America, e que tem por fim igualmente patentear aos mercados consumidores o aperfeiçoamento $e$ as especialidades das differentes producções que forem susceptíveis de consumo ou applicadas a transações e estabelecer as recíprocas relações commerciaes, base da prosperidade do desenvolvimento das industrias e riqueza do Estado ${ }^{8}$ :

\section{RESOLVE}

1‥ Approvar o Programma e Instrucções Regulamentares para inauguração de uma EXPOSIÇÃO AGRÍCOLA, INDUSTRIAL E DE MANUFACTURAS, comprehendendo os productos naturaes, artefactos e quinquilerias de grande e pequena industria, organisado pelo Director da

8 Grifo nosso. 
Secretaria Geral dos Negocios do Estado, Alcibiades Leite, como ponto inicial para a representação deste Estado na EXPOSIÇÃO PERMANENTE DO MUZEU COMMERCIAL DE PHILADELPHIA no Estado da Pensylvania, da Republica dos Estados Unidos da America do Norte. (EXPOSIÇÃO, 1899, p. 5-6)

As razões do deslocamento desse acervo para Museu Comercial requer situar a importância dessa instituição no período, como parte do projeto americano que, a partir de 1876, inicia sua entrada como palco das mostras universais, tendo a cidade da Filadelfia como lócus (PESAVENTO, 1997). A partir deste evento, seus organizadores, ao verificarem a importância das feiras universais, inauguram em 1897, um espaço que poderia abrigar, de maneira permanente e renovada a possibilidade de acesso às mercadorias do mundo, um local de classificação e apresentação de possibilidade de negócios, através da exposição da cultura material decorrente da agricultura, indústria, manufaturas manuais e do comércio. Assim, em 1899, o Museu inicia suas atividades ao hospedar a Exposição Nacional de Exportação, e torna-se, imediatamente, a fonte primordial de informação de comércio internacional para os indivíduos empreendedores (WOLFROM, 2010). O Museu oferecia a possibilidade de síntese de um maior número de informações possíveis de várias partes do mundo para fins comerciais. Além da mostra permanente de cultura material presente em suas vastas exposições permanentes (Figura 3) abrigava um parque gráfico com a impressão de periódico próprio e serviço de mala direta, além de biblioteca especializada e serviços pedagógicos às escolas, setor de estatística da economia mundial, e de tradutores de textos diversos (WOLFROM, 2010).

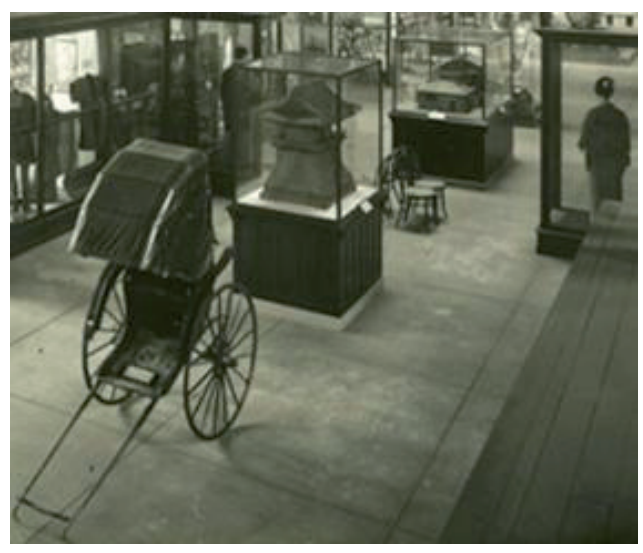

Fig. 3 - Vista do Museu Comercial - coleção japonesa. 1910 
De acordo com o Programa a participação de Sergipe na exposição do referido Museu, significa:

[...] patentear aos mercados consumidores o aperfeiçoamento e as especialidades das differentes producções que forem susceptíveis de consumo ou applicadas a transações e estabelecer as recíprocas relações commerciaes, base da prosperidade do desenvolvimento das industrias e riqueza do Estado (EXPOSIÇÃO, 1899, p. 6).

A presença de acervos brasileiros em Museus no exterior, sobretudo, os comerciais é verificada desde o século XIX. Iniciativa decorrente dos organizadores das mostras universais para criar um novo modelo com maior duração, uma vez que essas mostras, além de onerosas tinham implicações na natureza temporária das mesmas: "era chegada a hora de propor uma nova modalidade de exposição capaz de fazer o duplo trabalho de expor e divulgar as inovações tecnológicas, as criações artísticas e os estudos etnográficos e ainda fomentar o comércio nacional e internacional" (BORGES, 2007, p. 99). A participação de Sergipe neste momento representa a sua inserção direta no roteiro das grandes mostras internacionais de longa duração que seria transposto para o Brasil em 1907, com a criação do Museu Comercial do Rio de Janeiro e do Serviço de Propaganda e Expansão Econômica do Brasil no Estrangeiro.

A formação desses museus comerciais ao longo da segunda metade do século XIX e nos primeiros anos do XX é indicada por Borges (2007. p. 100) quando observa a sua finalidade:

Estruturados, em geral, a partir da parceria entre poder público e associações comerciais, os museus comerciais deram grande suporte ao comércio que a Europa mantinha com suas colônias e com as jovens nações iberoamericanas. Nossas evidências indicam que tanto o Brasil quanto o México adotaram essa modalidade de publicidade comercial que se tornou rotina nas grandes cidades, sobretudo portuárias, européias a partir das duas últimas décadas do século XIX.

O Programa indica, portanto, que Sergipe, assim como os demais recém-criados Estados iniciava sua "inserção na modernidade" através da exposição de seus produtos e inovações técnicas, mas, também, 
ao apresentar a sua história ${ }^{9}$ como um fator essencial à formação e fortalecimento do Estado, uma "museificação política" (ANDERSON, p. 251): a reprodutibilidade de insígnias, uma laicização da tradição - a incorporação de heranças políticas em andamento, como a valorização e criação de monumentos, unificação da história pela reprodutibilidade.

\title{
As exposições na Revista Agrícola, da Associação Agrícola de Sergipe (1905-1908)
}

De acordo com Barbuy (1996, p. 211), as exposições universais se constituíam na mais condensada representação material do projeto capitalista no mundo. Apesar de uma nova imagem de progresso para o Brasil ser considerada por alguns autores a partir da República (BORGES, 2007, p. 95), a participação do Brasil nas exposições anteriores pode rever essa ideia, afinal, o progresso, mesmo nos idos do Império figurava nos discursos que previam um modelo de nação, não só nas mostras universais, como também nas exposições nacionais realizadas no então Brasil Império, como a de 1873, no Rio de Janeiro:

\begin{abstract}
A exposição realizada na Escola Central do Largo de São Francisco esteve aberta por cerca de um mês. Menos pretensiosa que as demais, as províncias apresentaram seus produtos: o carvão de pedra do Rio Grande do Sul e Santa Catarina; o café do Rio de Janeiro, que também comparecia com a sua indústria de metais, trabalhos de marcenaria, louças, tecidos, fumos, vinho, cerveja, chapéus, sapatos, velas, sabão, papel. (PESAVENTO, 1997, p. 144-145).
\end{abstract}

Obviamente que existem diferenças cruciais entre os projetos de nação para o Brasil no Império e na República, mas o uso que se faz das palavras, sobretudo de signos como o progresso, aparecem associados, com significações semelhantes aos dois modelos de política vigentes nos respectivos períodos. A emergência da República em 1889 não é o fim de ideários e projetos anteriores, ou uma sequência linear de causa e efeito, mas, como analisaram Herschmann e Pereira (1994, p. 19): "não se trata de enfatizar uma continuidade, mas de ressaltar as estratégias desfechadas pela elite na sua tentativa de perpetuação no poder

9 Há no Programa a "Secção V - Sciencias, Litteratura e Historia" que apresentaria documentos históricos e geográficos, mapas, cartas e plantas, estatísticas etc. 
e de defesa de seus interesses". Logo, existiriam mudanças no sentido de novas formas de pensar, mas, também, reestruturações no poder. E essas possiveis estratégias seriam disseminadas em alguns suportes que poderiam fornecer indícios da tensão e conflitos entre as classes na então República. Uma República, uma ideologia, que sedimentaria o Estado brasileiro, definindo-o a partir da espacialização do capitalismo e do início de seu processo de mundialização (CHESNAIS, 1996).

E, nesse processo, os periódicos são veículos de divulgação das ideias e "novidades" vigentes. O primeiro número da Revista Agrícola de 15 de janeiro de 1905, uma publicação da Sociedade Sergipana de Agricultura, destacou entre suas "Noticias Diversas" a participação do Brasil na Exposição Universal de St. Louis em 1904:

Exposição de S. Luiz

Sobre este grande certamen a quem concorreram todas as nações do mundo, escreveu ao "Correio Paulistano" o Dr. Francisco Ferreira Ramos, relativamente a posição do Brazil ali representado e dos prêmios obtidos, que se lê em seguida:

[...] "O Brazil é um paiz que começa a despertar, disse-nos um Professor da grande nação". É preciso agora não pararmos nisso e tirar partido dos elementos já accumulados. A exposição de Lousiania veio salientar um facto de elevado alcance para nós, nessa grande feira ficou provado que é a agricultura que reside a principal grandeza dos Estados Unidos da America do Norte!...

É nos gêneros de primeira necessidade, nas forragens, na cultura do algodão, e na industria pastoril que rezide a principal grandeza do paiz. Foi daí que surgiu essa serie de industrias e de emprehendimentos que hoje representam a grandeza da América do Norte.

A primeira condição para que um povo possa fundar e desenvolver suas industrias, é possuir gêneros de primeira necessidade abundantes e baixo preço. (...) (REVISTA AGRÍCOLA. n. 1, p. 7-8, 15/01/1905)

O destaque a agricultura é constante nas diversas medidas de sucesso econômico da nação brasileira. De tal maneira que, desde a segunda metade do século XIX, na montagem da primeira exposição nacional, que se via para $\circ$ Brasil a agricultura como o principal fundamento de riqueza (PESAVENTO, p. 102). Neste sentido, a agricultura aparece 
diluída sob várias formas de representação nas seções das mostras: "I. Productos naturaes; II. Industria; III. Manufacturas; IV. Artes; V. Sciencias, Literatura e História; VI. Mechanica" (EXPOSIÇÃO, 1899, p. 12-14).

Como arte de expor mercadorias que acompanha o avanço do capitalismo, as exposições fornecem um arcabouço discursivo ao reunir em um mesmo espaço o objeto, a linguagem e o público. O desejo de expor nasce atrelado ao desenvolvimento dos países produtores de mercadorias. E a propaganda é, sem dúvida, o grande baluarte do capitalismo, ao criar, sobremodo, um arcabouço em torno dos produtos como forma de aumentar o lucro e escamotear as relações de produção envolvidas: "artifício de sedução social, a publicidade e a propaganda não são pura criação ou arbitrariedade imposta: elas se apóiam em tendências latentes, em desejos manifestos, em inclinações não implícitas, mas detectadas, e as manipulam, induzindo ao consumo, à aceitação, ao maravilhamento" (PESAVENTO, 1997, 49).

A Revista Agrícola pode ser considerada como uma fonte inserida em um projeto de produção de uma linguagem unificada para/sobre o meio rural sergipano e suas vinculações ideológicas no sentido geo-político. A imprensa como um suporte de linguagem da classe dominante ${ }^{10}$, é uma das formas de apresentar suas ideias "toda classe dominante é obrigada, para atingir seus fins, a apresentar seu interesse como o interesse comum de todos os membros da sociedade, é obrigada a dar às suas ideias a forma de universalidade, a apresentá-las como as únicas racionais, universalmente válidas" (MARX e ENGELS, 2007, p. 48).

A partir dessa análise, as ideias da classe dominante - agricultores, comerciantes, industriais, intelectuais - para serem reconhecidas como válidas, encontrariam no discurso veiculado na Revista, as idéias de sua dominação, a naturalização de sua vontade, de sua razão, sua visão de mundo sobre o meio que a cerca. Aspecto que pode ser denotado na transcrição que se segue:

\section{Exposições estadoaes}

Estado do Rio de Janeiro prepara-se para effectuar, este anno, uma exposição de productos agrícolas, industriaes e pastoris fluminenses, com secções especiaes para fructos e flores. A Bahia pretende também exhibir no Lyceu de Artes e Officio os seus

10 O conceito de classe dominante é aqui compreendido como a classe que tem à sua disposição os meios materiais de produção e as idéias. 
productos que julgamos causarão sucesso por sua importância e multiplicidade. São Paulo já fez sua exposição de gado, e o Paraná secundou a Capital Federal com sua explendida exposição de álcool.

Nós é que nada poderemos tentar, por que ainda que muito tivéssemos para expor (e sempre temos alguma cousa) não teriamos quem visse a nossa exposição pela difficuldade de accesso do nosso Estado $^{11}$. Decididamente a estrada de ferro entre nós é todo o nosso futuro; sem ella todo o nosso esforço será baldado. Até quando esperaremos por semelhante benefício? (REVISTA AGRÍCOLA. n. 36, p.358-359, 15/07/1906).

As queixas de 1906 da não participação de Sergipe em mostras parecem conflitar com os anseios do Programa de 1899. Contudo, a construção de uma ideia de isolamento do estado, e, sobretudo, do campo, pode ser considerada como uma saída para referendar com louvores determinadas situações e projetos, como se lê no júbilo com o recebimento do convite para a participação de Sergipe na exposição de 1908 no Rio de Janeiro. Notícia que mereceu matéria de primeira página na Revista Agrícola de 15 de julho de 1907 com informes sobre publicação de Ato pelo Presidente do Estado designando comissão para angariar os produtos a figurar no "certamen":

O primeiro passo está patrioticamente dado... resta que todas as classes sergipanas, todos os espíritos que amam esta terra... venham ao encontro de tão brilhante certamen (...) fugir disso é fugir do cumprimento de um dever, é um crime para com Sergipe, que deante dos outros Estados, em face do mundo, devo ostentar e manifestar sua individualidade própria, tanto mais digna de admiração e de apreço... A Sociedade Sergipana de Agricultura estará coadjuvando a comissão... não será fora de propósito lembrar que, a semelhança de outros Estado, os productos que serão enviados para a Capital Federal sejam aqui previamente expostos, afim de que os Sergipanos possam apreciar, no seu conjunto, a manifestação dos progressos de nosso pequeno e estremecido Estado. (...) Todos os productos, poderão, para este fim, ser enviados para um deposito,

11 Grifo nosso. 
onde sejam acolhidos e tratados com todo o zelo, para o Trapiche Lima, por exemplo, donde sahirão para o edifício destinado para a exposição prévia (...) (REVISTA AGRÍCOLA. p. 581-582, 15/07/1907)

Após a euforia da publicação dessas informações a Revista Agrícola veicula poucas referências em 1908 sobre os trabalhos da "Directoria Executiva da Exposição". Constam apenas informações sobre regulamentos a serem cumpridos pelos expositores: rol de perguntas de um questionário que deverá acompanhar cada produto especificando dados sobre a produção, valor de comercialização, a distância do centro de produção ao porto de embarque ou estrada de ferro, fretes, impostos pagos até o centro de consumo (tratando-se de produto industrial), o tipo de matéria-prima empregada, se nacional ou estrangeira (REVISTA AGRÍCOLA. p. 699-700, 01/01/1908). Outro exemplar desse periódico expõe sobre determinações específicas para a exposição de flores, frutas e horticulturas, além de uma descrição detalhada do pavilhão de São Paulo a ser construído para a mostra (REVISTA AGRíCOLA. p. 728-729, 15/02/1908). A última referência encontrada na Revista veicula sobre regulamento especial da entrada na exposição, trata da venda de bilhetes e formas de acesso diferenciado para expositores e visitantes, e para a imprensa local e estrangeira, as normas para transporte de volumes no espaço da exposição (REVISTA AGRÍCOLA. p. 757-758, 01/04/1908).

\section{Observações Finais}

Fundado no princípio que - a imprensa é a luz (FARO, Evangelino de. 15/07/1907, Revista Agrícola, p. 582).

O registro da participação de Sergipe nas exposições de caráter internacional e nacional permite perceber a vinculação discursiva entre aqueles que produziam a indústria, a agricultura e o comércio. O campo, de acordo com as notícias, emerge como fornecedor de capital para a indústria. No entanto, essa lógica parece contraditória. O campo é referido como atrasado, mas, o seu desenvolvimento tecnológico seria a condição do progresso industrial e comercial: "um país em que se tratava de estabelecer a indústria, os caminhos do progresso técnico passavam, necessariamente, pela modernização agrária" (PESAVENTO, 1997, p. 71), contudo, o discurso publicado não era uníssono, apesar dos esforços sempre reiterados na fala dos autores das matérias da Revista e do Programa da exposição. 
A propaganda - os artifícios de convencimento, e a publicidade - a divulgação das exposições, são compulsadas não apenas como fator para a exposição de produtos definindo pavilhões e stands, e legendas, mas, como ferramentas discursivas presentes nos impressos que, ao compor discursos, justificam a ampliação de mercados (DEL PRIORI; VENÂNCIO, 2006, p. 172), e também passam a ser incorporadas no arcabouço de um vocabulário para a modernização do campo sergipano. $O$ Programa de 1899 e as Revistas de 1905 a 1908 e outras possíveis fontes representam apenas indícios de um tecido maior que deve ser cerzido à luz da produção do espaço capitalista e dos meandros de sua espacialização, entre eles, os discursos impressos a serem desvelados como parte de um capitalismo tipográfico e da produção de uma linguagem para/sobre o campo sergipano que naturalizam as formas de exploração do capitalismo. 


\section{Referências}

ANDERSON, Benedict. Comunidades Imaginadas: reflexões sobre a origem e a difusão do nacionalismo. Tradução de Denise Bottman. São Paulo: Companhia das Letras, 2008.

BAKHTIN, Mikhail. Marxismo e Filosofia da Linguagem. São Paulo: Hucitec, 1997.

BARBUY, Heloisa. O Brasil vai a Paris em 1889: um lugar na Exposição Universal. Anais do Museu Paulista. São Paulo. 1996, vol.4, n.1, p. 211261.

BORGES, Maria Eliza Linhares. Representações do Brasil Moderno para ler, ver e ouvir no circuito dos Museus Commerciais europeus, 1906 a 1908. História. São Paulo. vol.26, n.2, p. 92-117, 2007.

CHESNAIS. F. A mundialização do capital. Tradução Silvana Finzi Foá. São Paulo: Xamã, 1996.

DEL PRIORI, Mary; VENÂNCIO, Renato. Uma história da vida rural no Brasil. Rio de Janeiro: Ediouro, 2006.

EXPOSIÇÃO Commemorativa Sergipana em Aracaju. Certamen Agricola, Industrial e de Manufacturas. Programa e Regulamento. Aracaju: Typ. do O Estado de Sergipe, 1899.

HARVEY, David. A produção do espaço capitalista. 2.ed. Tradução de Carlos Szlak. São Paulo: Annablume, 2006.

HERSCHMANN, Micael; PEREIRA, Carlos Alberto M. (Org.). A invenção do Brasil Moderno. Medicina, educação e engenharia nos anos 20-30. Rio de Janeiro: Rocco, 1994.

HOBSBAWM, Erick. A Era do Capital, 1848-1875. 15.ed. Tradução de Luciano Costa Neto. São Paulo: Paz e Terra, 2010.

MARTINS, Ana Luiza. Revistas em Revista: imprensa e práticas culturais em tempos de República, São Paulo (1890-1922). São Paulo: Editora da Universidade de São Paulo: Fapesp, 2008.

MARX, Karl e ENGELS, Friedrich. A Ideologia Alemã: crítica da mais recente filosofia alemã em seus representantes Feuerbach, B. Bauer e 
Stirner, e do socialismo alemão em seus diferentes profetas (1845-1846). Tradução Rubens Enderle, Nélio Schneider, Luciano Cavini Martorano. São Paulo: Boitempo Editorial, 2007.

MENESES, Ulpiano T. Bezerra de. A exposição museológica e o conhecimento histórico. In: FIGUEIREDO, Betânia G.; VIDAL, Diana G. Museus: dos gabinetes de curiosidades à museologia moderna. Belo Horizonte: Argvmentum; Brasília: CNPq, 2005. p. 15-84.

OLIVEIRA, Lúcia Lippi. Cultura é Patrimônio: um guia. Rio de Janeiro: Ed. da FGV, 2008.

PESAVENTO, Sandra Jatahy. Exposições Universais: espetáculos da modernidade do século XIX. São Paulo: Hucitec, 1997.

PRATT, Mary Louise. Os Olhos do Império: relatos de viagem e transculturação. Tradução Jézio Hernani B. Gutierre. Bauru, SP: EDUSC, 1999.

REVISTA AGRÍCOLA. Aracaju: Sociedade Sergipana de Agricultura; Imprensa Moderna, 1905-1908.

SANTOS, Paulo Coelho Mesquita; COSTA, Adilson Rodrigues da. A Escola de Minas de Ouro Preto e as "Seções de Geologia" do Brasil nas Exposições Universais. REM - Revista da Escola de Minas. Ouro Preto, MG. vol.59, n.3, p. 347-353. 2006.

SEVCENKO, Nicolau. Literatura como Missão: tensões sociais e criação cultural na Primeira República. 2.ed. São Paulo: Companhia das Letras, 2003.

VERÍSSIMO, Maria de Lurdes. As Exposições Universais: Reflexo de Esperanças e Contradições dos Últimos 150 anos. Latitudes, $n^{\circ} 3, p$. 31-32, juil., 1998. Disponível em: http://www.revues-plurielles.org/_uploads/pdf/17_3_7.pdf. Acesso em: 20 de junho de 2010.

WOLFROM, Katelyn A. Commercial Museum History. Disponível em: http://www.phillyseaport.org/web_exhibits/mini_exhibits/mini_exhibits/ philadelphia_commercial_museum/. Acesso em 15/06/2010. 
20.

\section{Cultura de exposições em São Paulo, no século XIX}

Heloisa Barbuy

A idéia da qual partiremos é de que no século XIX, ainda mais ampla do que a proliferação de museus que o marcou², deu-se o estabelecimento de algo que chamaremos de cultura de exposições, que permeou o cotidiano das cidades capitais na Europa, manifestando-se nos interstícios de sua vida urbana. Como elemento integrante dos processos de internacionalização que se intensificaram na segunda metade do século XIX, essa cultura de exposições germinou, também, em outras regiões do globo, com um sem-número de pequenas e grandes mostras, demonstrações e espetáculos baseados na linguagem didática da exibição organizada de coisas.

O recorte espacial e temporal do presente estudo é a cidade de São Paulo na segunda metade do século XIX. O campo em que ele vem se desenvolvendo é o da cultura material e, mais especificamente, o da cultura visual, com certa particularidade, no entanto, em relação ao que vem predominando neste último, pois no presente estudo não se identifica a cultura visual apenas com a imagem dita bidimensional ou plana (pintura, fotografia e outras) ou com a imagem associada à tecnologia ${ }^{3}$, mas se a estende a um dispositivo especialmente organizado para a apreensão sensível e sobretudo visual, no qual o espaço é essencial, e que sistematiza objetos tridimensionais: a exposição.

1 Museu Paulista da Universidade de São Paulo.

E-mail: hbarbuy@usp.br

2 Ver SCHAER (1993), GEORGEL dir. (1994) e, para o caso braileiro, LOPES (1997).

3 Para um balanço sobre Cultura Visual como área acadêmica, ver DIKOVITSKAYA (2006). 
Desde que Eilean Hooper-Greenhill ${ }^{4}$ definiu a comunicação feita no museu - a relação entre museu e visitante - como algo que deve ser examinado no campo da cultura visual, abriu caminho para tratarmos a cultura visual não apenas em seu universo academicamente predominante, associado às imagens em sentido estrito, mas também ligada ao amplo espectro de sistemas organizados para a apreensão visual, entre eles as exposições. Sobretudo quando se trata do século XIX, as exposições, assim como a intensa produção de imagens associadas a diferentes recursos, inserem-se, de fato, em tendências e práticas culturais mais abrangentes, que têm a visualidade como eixo de expressão e compreensão do mundo, cabendo falar numa cultura visual própria desse período.

Por outro lado, nas investigações sobre uma cultura de exposições, deparamo-nos com outros elementos relevantes, não diretamente ligados à cultura visual, e que devem ser considerados para que se possa atingir uma compreensão mais profunda do conceito de exposições, de sua função social e de seu papel nas dinâmicas da internacionalização cultural. Entre eles, a relação entre a cultura de exposições e a cultura científica do século XIX.

A modernidade, entendida como processo de ruptura com as tradições, que teve como eixo as extensas mudanças materiais inerentes à industrialização e ao capitalismo, trouxe a introdução, em centros urbanos, de apelos visuais de diferentes tipos, associados tanto aos mecanismos de sedução então desenvolvidos, como à necessidade de compreensão do mundo novo que se delineava e que exigia uma adaptação. As exposições tornaram-se, assim, um meio de comunicação essencial no século XIX, conjugando diversão e instrução, "binômio" característico de todo este processo.

\section{Cultura de exposições em São Paulo}

Em São Paulo, na segunda metade do século XIX, a formação de um ambiente cosmopolita teve como componente relevante a ocorrência de uma sucessão de exposições abertas ao público. A cultura de exposições que então se instala, inclui formas populares ou leigas de veicular e absorver conhecimentos novos, na confluência de uma cultura científica com a curiosidade e promove, ainda, a difusão de vocabulário e valores científicos.

4 HOOPER-GREENHILL (2000). 
Para nosso estudo, identificamos alguns dos veículos que terão disseminado a cultura de exposições em São Paulo, aqui definidos em sete itens, sendo que passaremos mais rapidamente pelos cinco primeiros para nos determos um pouco mais nos dois últimos.

1. Museu - a existência, na cidade, de um museu particular, pertencente ao Coronel Joaquim Sertório, que era aberto a visitantes selecionados, é um indicador de que o contexto paulistano já dava sinais de uma prática de exposições. Mais tarde, a Coleção Sertório veio a se constituir no núcleo inicial do acervo do Museu Paulista, primeiro museu público do Estado de São Paulo, criado juridicamente em 1893 e inaugurado em 1895. A instalação do Museu Paulista pode ser considerada como um ápice na cultura de exposições em São Paulo 5 .

2. Primeiras exposições institucionais - Antes mesmo da criação do Museu Paulista, já havia pelo menos uma exposição institucional, constituída pela galeria de retratos em pintura de antigos professores da Faculdade de Direito. Já existia em 1883 e já era mencionada como "Galeria de Retratos" pelo menos desde $1892 .{ }^{6}$ A Faculdade de Direito era uma instituição-chave como centro de formação dos principais quadros políticos do país.

3. Exposições de artigos comerciais - $\mathrm{Na}$ segunda metade do século XIX, pode-se detectar transformações bastante visíveis nas estratégias comerciais das lojas estabelecidas no centro urbano de São Paulo. Talvez a mais eloqüente de todas seja a introdução de vitrines, nas quais passaram a se organizar exposições de artigos oferecidos ao consumo. De fato, até meados do século XIX, o padrão de comércio em vigor era aquele dos armazéns, sem preocupação em criar mecanismos de sedução para atrair compradores para novos produtos. A partir daí, vitrines são instaladas, esteticamente arranjadas e inclusive anunciadas nos jornais como exposições, usando-se exatamente este termo ${ }^{8}$.

4. Exposições artísticas locais - Antes de existirem museus públicos e galerias de arte na cidade, os próprios comerciantes instalados nas ruas centrais, grupo social com papel destacado

5 Museus escolares passam a ser organizados pelo Museu Paulista mas é possível que já existisse esse tipo de mostra didática em estabelecimentos de ensino então existentes.

6 COMISSÃO DE MUSEU DA FACULDADE DE DIREITO (2002); GROLA (2009: 146-157).

7 Sobre a Faculdade de Direito, ver, entre outros, MARTINS e BARBUY (1998).

8 BARBUY (2006) 
na dinâmica da vida urbana, incumbiam-se de oferecer exposições de obras de arte em seus estabelecimentos. ${ }^{9}$

5. Exposições de curiosidades - Expor fenômenos da natureza ao público também era uma prática usual. Foi o caso, por exemplo, em 1875, de uma exposição no Hotel Europa, na rua do Rosário. Um anúncio de jornal informava que se achavam "à exposição por dois dias somente estes formidáveis animais, dos quais o primeiro mede 25 e o outro 15 palmos". Era cobrada entrada no valor de 500 réis. $^{10}$ Este tipo de ocorrência insere-se numa tendência mais ampla e anterior, da curiosidade e da observação em relação às coisas da natureza, que esteve na base dos desenvolvimentos científicos e fundamentou a germinação do museu moderno. ${ }^{11}$

6. Exposições itinerantes vindas da Europa - Percorrendo as páginas de jornais paulistanos daquele período, verificam-se freqüentes anúncios de exposições itinerantes vindas da Europa, com objetivos comerciais e apelo popular, muitas vezes em torno do conhecimento científico. Os registros que restaram da passagem dessas exposições pela cidade de São Paulo no século XIX permitem recuperar elementos significativos a respeito de sua realidade e do sentido que podiam ter no ambiente cultural em que se inseriam. ${ }^{12}$

É o caso, por exemplo, de uma exposição de peças artísticas de vidro, organizada por um italiano de nome Mucci, procedente de Florença juntamente com sua família. Em anúncio publicado em jornal, em 1854 ${ }^{13}$, alguns elementos podem ser sublinhados: 1ㅇ) o caráter internacional conferido à exposição ao indicar-se que apresentam em São Paulo suas obras, "assim como em muitos países do mundo"; 2ํ) dirigem-se a um "público ilustrado", isto é, trata-se de um evento de interesse intelectual,

9 BARBUY (2006) e TARASANTCHI (2002).

10 Correio Paulistano, 27 fev. 1875.

11 Ver, entre outros, SCHAER (1993).

12 Em seus estudos sobre museus e exposições na Argentina, Irina Podgorny deparou-se com o caso particular de um charlatão de nome Guido Benatti, que itinerava pela Argentina apresentando-se como médico com poder de cura, adepto das teorias do "magnetismo animal" e que acabou por conseguir lugar de destaque na formação de acervos argentinos (PODGORNY, 2008). Em nosso caso, ativemo-nos ao papel que possam ter tido exposições itinerantes na formação de uma cultura de exposições em São Paulo. Investigações a respeito das trajetórias de seus responsáveis são possibilidades em aberto e devem apontar para um circuito de cidades de alcance talvez continental.

13 Correio Paulistano, 26 set. 1854 
a cujos interessados se pede não um pagamento meramente comercial mas sim uma "contribuição de $2 \$$, recebendo à saída uma peça pequena, cujo valor seja menor que o preço da entrada"; 3) ostenta-se um espetáculo visual de quantidade e a variedade, que são valores na sociedade industrial, ao afirmar que "expõem dous mil metros de cristal ou vidro reduzido à finura de seda, penas, pássaros, tubos, cavalos, fontes, toda espécie de animais, tubos capilares, e um sem número de cousas feitas sem molde e sem ferramenta alguma"; 4ㅇ) Requinte e apuro técnicos são sugeridos quando se faz menção ao domínio da matéria (tudo em "cristal ou vidro"), à pouca espessura obtida ("finura) e à capacidade de produzir as peças em questão sem instrumento algum ("sem molde e sem ferramenta"), certamente referindo-se à técnica do vidro soprado, na qual se sobressaiam os italianos; $5^{\circ}$ ) Associa-se a exposição a uma atividade didática, já que o Sr. Mucci "dá também lições a quem as desejar tomar"; 6) Atribui-se-lhe um caráter científico ao chamá-la de "laboratório"; 7ㅇ) também um caráter democrático pois ensina-se a quem desejar aprender e o laboratório fica "aberto das 9 horas da manhã às 10 da noite".

Em 1858, no mesmo jornal, é anunciado um "Gabinete Óptico"14, chamada que por si só já introduz o leitor (e o visitante da exposição) num universo científico. Trata-se de uma "exposição de vistas", que perfila imagens cujos temas estão entre aqueles de predileção no século XIX ${ }^{15}$ : primeiramente, a representação do próprio locus em que se realiza o cosmopolitismo, as cidades capitais: "as principais capitais como Paris, Londres, Lisboa, Rio de Janeiro, Constantinopla, S. Petersburgo, etc."; depois, lugares naturais fenomenais, "objetos os mais notáveis da natureza, como o terrível vulcão ou montanha de fogo de Nápoles"; igualmente, guerras históricas "como a grandiosa guerra da Rússia"; por fim, temas religiosos, seja de lugares de culto existentes, como a "praça de S. Pedro em Roma, o Real Santuário do Bom Jesus do monte de Braga em Portugal", seja de cenas bíblicas, como "a rica vista de Jesus subindo o Calvário" ou "a destruição de Sodoma pelo fogo celeste". Neste anúncio, é valorizado o realismo das imagens ("do mais natural e perfeito que existe neste gênero"), assim como, mais uma vez, a quantidade e a variedade, ao se dizer tratar-se da "coleção mais abundante e variada que tem aparecido no Brasil".

14 Correio Paulistano, 13 ago. 1858.

15 Bernard COMMENT (1993: 6-7), ao tratar dos panoramas no século XIX, discerne algumas tipologias temáticas então recorrentes: a cidade, a guerra e a viagem, esta última subdividida em viagens a cidades patrimoniais, como Roma, Nápoles, o Etna ou Constantinopla (incluídas nas vistas da mencionada exposição em São Paulo), paisagens sublimes e lugares exóticos. 
Um outro caso se dá em 1875, ocasião em que passa por São Paulo uma exposição de figuras de cera, que faz confluir técnicas científicas, temáticas religiosas e características de espetáculo popular. No século XIX, as figuras de cera em tamanho natural tiveram grande difusão como modo realista de representação. ${ }^{16}$ Exatamente pelo realismo que proporcionam, criando imagens tridimensionais que parecem atestar verdades, tinham grande apelo popular, mas em razão das mesmas propriedades que permitem criar realidades materiais detalhadas, tanto por imitação como por invenção, foram intensamente utilizadas em centros científicos para fazer réplicas ou modelos que tinham como referência a natureza ou cenas do passado tal como concebidas pela ciência ou pela história. ${ }^{17}$ Por isso, para inspirarem credibilidade, sua confecção devia ser realizada por técnicos realmente especializados. Assim, ao anunciar ${ }^{18}$ a exposição de figuras de cera que itinerava por São Paulo, sublinhou-se tratar-se de "escolhidas figuras de cera, únicas admitidas na Exposição de Viena d'Áustria, executadas pelo célebre modelador da Academia de Medicina de Paris, Jules Talrik", conferindo-lhe, deste modo, um caráter científico. O que representavam, porém, eram cenas e figuras bíblicas, como "o primeiro homem do mundo, Adão, perfeitamente semelhante ao Adão que nos pinta a história. Eva com todos os atrativos que devia ter a primeira mulher", casando, possivelmente, a temática científica sobre as origens da humanidade e do mundo com sua explicação religiosa. No ambiente expositivo, "um clown, fazendo no trapézio os mais difíceis equilíbrios (...)" e "um zuavo fumando, conversando com o público, tocando tambor pela eletricidade", isto é, um tipo de atração de feira popular, porém com equipamento moderno, movido a força elétrica. Tudo se dava na rua Direita, no pavimento térreo do Hotel de França, a essa época o principal hotel de São Paulo. Era cobrado ingresso, sendo a entrada gratuita para crianças de até oito anos acompanhadas de seus parentes.

Vinte anos mais tarde, em 1895, foi anunciada uma nova exposição de figuras de cera em São Paulo, desta vez no Teatro Apolo e avocandose mais francamente um caráter científico ao apresentar-se como "a grandiosa e instrutiva exposição artístico-científica de Henrique Dessort"

16 De uso freqüente em exposições do século XIX na Europa (GEORGEL, 1994: 52-57), as figuras de cera já estavam presentes nos gabinetes de curiosidades e, por esta razão, Julius von SCHLOSSER, curador do Museu de História da Arte de Viena na passagem do século XIX para o XX, e pioneiro nas pesquisas sobre as coleções renascentistas, nas quais eram freqüentes os bustos em cera, escreveu uma obra sobre o tema, editada pela primeira vez em 1911.

17 Sobre o uso de figuras de cera na Exposição Universal de 1889 em Paris e na Exposição Nacional de 1908 no Rio de Janeiro, ver BARBUY (1995: 53-54 e 2002: 68-70).

18 Correio Paulistano, 30 jan. 1875. 
e intitular-se como "museu anatômico e etnológico", com "mais de mil preparados em cera". ${ }^{19}$ Mesclavam-se, agora, temas mitológicos (como Vênus e Cupido), bíblicos (como Madalena penitente) e de interesse científico, nos campos da biologia (como irmãos siameses), etnologia (como uma menina etíope) ou arqueologia (como uma Vênus hotentote). Pelo que é elencado, presume-se que embora encarada como uma exposição científica, evidenciava um espírito de curiosidade, isto é, aquele tipo de interesse por tudo o que é mistério da natureza, associado, porém, a explicações não necessariamente científicas. $O$ comentário jornalístico anônimo, publicado no dia seguinte à inauguração da exposição, resumiu-a da seguinte forma: "curiosa exposição de figuras de cera, tipos de mulher, de bugres, deformidades, casos anatômicos, certos mistérios do organismo humano, etc." Por ser considerada impressionante ou realista demais, só era permitida a entrada de "adultos de ambos os sexos" e o comentarista julgou que parte das coisas ali expostas eram "mais próprias para serem vistas por homens", embora houvesse "muitos outros objetos que não causar[iam] certo sobressalto ao sexo amável"; que era "um museu muito interessante".

Anúncios e comentários jornalísticos permitem-nos, hoje, tomar conhecimento de uma ocorrência freqüente de exposições itinerantes em São Paulo. Até onde sabemos, não há fotografias dessas exposições mas os textos veiculados são suficientes para termos uma idéia mais ou menos concreta do que foi apresentado, embora nada haja de mais preciso sobre sua disposição espacial. Sobre a recepção pelo público, mesmo não havendo indicações a respeito, entendemos que os comentários jornalísticos que por vezes suscitam podem ser entendidos como uma forma de depoimento de visitante. A própria ocorrência dessas exposições é significativa e sua inserção no que se conhece sobre o contexto urbano e social de São Paulo, torna interessante tomá-las como objeto de pesquisa.

7. Sistema oficial de exposições - A sucessão de grandes exposições internacionais da segunda metade do século XIX até a Primeira Guerra Mundial20, que teve início em Londres, em 1851, com a Great Exhibition of the Works of Industries of all Nations, no Palácio de Cristal, acabou por criar um sistema para realiza-

19 Correio Paulistano, 14/11/1895 (anúncio); 15/11/1895 (comentário jornalístico).

20 As exposições internacionais ou universais continuam a se realizar até os dias atuais mas os autores que se dedicam ao tema são unânimes em considerar que a Primeira Guerra Mundial representou mudanças extremamente significativas em sua filosofia, concepção e no sentido a elas atribuído. 
ção desses eventos. ${ }^{21}$ Eram geralmente organizadas pelo Estado anfitrião, com maior ou menor participação de empresas privadas, conforme a conjuntura de cada uma delas. Foram várias, sendo difícil chegar a um número preciso pois diferiam em porte e repercussão e também na importância que podiam ter para cada país envolvido. Algumas delas são inquestionavelmente as maiores e mais marcantes mas obras gerais sobre o tema incluem outros desses eventos e os pontos de vista locais ou continentais podem influir na seleção feita por cada um. ${ }^{22}$

As exposições internacionais, que ficaram mais conhecidas no Brasil pela denominação francesa de exposições universais, geraram a organização, nos países participantes, de exposições nacionais preparatórias e estas, por sua vez, podiam ser precedidas por exposições regionais. Estas últimas foram organizadas, no Brasil, como exposições provinciais e depois estaduais $^{23}$. Constituía-se, assim, um sistema oficial de exposições.

O que importa aqui é compreender de que modo esse sistema acabou por se tornar uma referência na São Paulo do século XIX, contribuindo para a germinação local da cultura de exposições de que estamos tratando. Entendemos que isto tenha se dado por três vias principais cujos registros vêm sendo nossas fontes documentais: notícias sistematicamente publicadas na imprensa sobre as grandes exposições realizadas na Europa e nos Estados Unidos; da mesma forma, notícias sobre as grandes exposições nacionais realizadas no Rio de Janeiro; a realização de exposições provinciais/estaduais e municipais na cidade de São Paulo.

Embora o Brasil tenha iniciado sua participação nesse sistema com a Exposição Nacional de 1861 e, a seguir, com sua presença na Exposição de Londres de 1862, a primeira exposição provincial organizada em São Paulo só ocorreu em 1875, como preparação para a Exposição Nacional do mesmo ano e a Exposição de Fildélfia de 1876. Consideramos que essa exposição provincial iniciou um ciclo, só finalizado em 1917, com a

21 Embora somente em 1928 viesse a se constituir um organismo internacional para sua regulamentação e gerência, o Bureau International des Expositions (BIE) http://www.bie-paris.org.

22 Ver, entre outros, UNION CENTRALE DES ARTS DECORATIFS (1989); SCHROEDER-GUDEHUS E RASMUSSEN (1992); GEPPERT, COFFEY E LAU (2006).

23 As exposições provinciais/estaduais ou municipais brasileiras, organizadas no sistema, nos padrões ou no sentido das exposições universais, ainda não foram suficientemente estudadas mas após um longo hiato havido desde a publicação da obra de FOOT HARDMAN (1988), que dedica o capítulo 3 a este tema, vêm surgindo alguns trabalhos acadêmicos sobre elas: SANTOS (2009), CUNHA (2010), LIMA (2008). 
exposição municipal que inaugurou o Palácio das Indústrias. A construção deste edifício tinha sido havia muito acalentada pois se desejava ter um lugar especialmente concebido para exposições agrícolas e industriais. Acabou se concretizando, porém, durante a I Guerra Mundial, num período que já era de ocaso das exposições universais, em cujo sistema se inseria ${ }^{24}$.

Vamos nos deter apenas na Exposição de 1875 mas convém antes elencar as exposições provinciais/estaduais de São Paulo e eventos correlatos organizados no período tratado: 1875 - Exposição Provincial; 1885 - Exposição Provincial; 1890 - lançamento da Exposição Continental; 1902 - Exposição Agrícola Pastoril e Industrial (Exposição Municipal); 1904 - Exposição preparatória para a Exposição de Saint-Louis; 1908 - Exposição preparatória para a Exposição Nacional; 1917 - Exposição Municipal de São Paulo.

Em janeiro de 1875, ao reproduzir a convocação dirigida ao presidente da comissão provincial paulista, Conselheiro Carrão ${ }^{25}$, pela comissão imperial ${ }^{26}$ encarregada de organizar a Exposição Nacional preparatória, o jornal Correio Paulistano dirigiu uma mensagem "Aos industriais paulistas", na qual deixava clara a tensão entre a ideologia conservadora, que atribuía ao Estado um papel de instigador e organizador, e a ideologia liberal, que entendia que as iniciativas deveriam ser deixadas aos empreendedores particulares. O tema era a necessidade de "... empregar desde já os esforços mais enérgicos para obter uma coleção, se não completa, pelo menos condigna, que revel[asse] a importância das nossas riquezas naturais e estado atual de desenvolvimento do trabalho entre nós". ${ }^{27}$

De todos os esforços havidos, resultou que em julho de 1875 era inaugurada a primeira Exposição Provincial de São Paulo ${ }^{28}$, no salão principal e mais algumas outras salas da Faculdade de Direito, tendo ficado aberta por mais de um mês ${ }^{29}$ e recebido cerca de 300 a 400 visi-

24 Ver Paula Coelho Magalhães de LIMA (2008).

25 Conselheiro João da Silva Carrão (presidente), Desembargador Bernardo Avelino Gavião Peixoto, Dr. Antônio Aguiar de Barros, Dr. Leôncio de Carvalho (AMARAL, 1980: 184).

26 Gastão de Orleans (presidente), Visconde de Jaguary, João Antônio de Azevedo, Visconde do Bom Retiro, Visconde de Souza Franco.

27 Convocação transcrita no Correio Paulistano, 6 jan. 1875.

28 Por ter sido considera muito modesta, uma espécie de "primeiro ensaio" (Correio Paulistano, 18 jul. 1875), em 1885, quando se organizou um outro evento desse tipo, deu-se a ele o nome de Primeira Exposição Provincial de São Paulo.

29 A exposição foi inaugurada em 8 de julho e recebeu a visita do Imperador Dom Pedro II no dia 18 de agosto. 
tantes por dia ${ }^{30}$. Nos discursos pronunciados, nas classificações dos produtos, nas formas de organizar a exposição e nos comentários jornalísticos havidos, percebe-se um vínculo com as exposições universais, uma busca por seguir seus padrões. Isto era conseqüência natural de seu caráter preparatório para a Exposição de Fildélfia mas, hoje, torna-se interessante apreender os modos pelos quais exposições locais foram inseridas nos sistema internacional pois isto nos permite examinar os mecanismos pelos quais se introduziram dispositivos e estruturas participantes de uma cultura de exposições em São Paulo.

Em termos do que chamamos hoje museografia ou expografia, é possivel extrair das descrições remanescentes elementos como a existência, no centro do salão principal, de "duas pirâmides, uma de sacos de café e outra de fardos de algodão em bruto e trançado, ostentando aquela uma bandeira nacional, bordada especialmente para figurar no alto do produto que constitui a nossa maior fonte de riqueza"31, em disposição que se mostra semelhante às que vemos nas fotografias e gravuras das exposições universais: um tipo de montagem que cria, logo na entrada, uma hierarquia entre os objetos expostos, deixando clara a importância central de um ou de outro produto. A idéia é apreendida visualmente - literalmente à primeira vista -, e ao se repetir em diferentes exposições acaba por criar um código visual, que treina o observador em sua condição de visitante de exposições.

As demonstrações de máquinas em movimento foram outra prática adotada nas exposições universais, nos Palácios de Máquinas e, embora em porte imensamente mais modesto, também na salas da Exposição Provincial de São Paulo de 1875. Em artigo intitulado "Máquinas diversas", o cronista anônimo do Correio Paulistano comenta:

"Nas grandes exposições internacionais as seções de máquinas causam verdadeira admiração. Aqueles que assistem a essas lutas grandiosas em que a França, a Inglaterra, os Estados Unidos e a Bélgica costumam figurar, cada qual mais pujante, cedendo aqui o passo para vencer ali, e saindo afinal todas cobertas de glória, não teria por certo muito que ver aqui no estreito espaço onde poucos expositores aparecem. / Não obstante pode-se dizer que, nas salas da Academia, diante de algumas máquinas, sente-se a vida da província de S. Paulo".32

30 O número foi divulgado pelo Correio Paulistano (22 jul. 1875). Ainda sobre a visitação, há anúncios da Companhia da Estrada de Ferro de S. Paulo oferecendo promoções nos preços dos bilhetes para a vinda de visitantes do interior da Província. (cf. Correio Paulistano, 9 jul. 1875).

31 Correio Paulistano, 9 jul. 1875.

32 Correio Paulistano, 25 jul. 1875. 


\section{Bibliografia e fontes}

AMARAL, Antônio Barreto do. Dicinário de História de São Paulo. São Paulo: Governo do Estado, 1980. (Col. Paulística, 19).

BARBUY, Heloisa. A Cidade-Exposição : comércio e cosmopolitismo em São Paulo, 1860-1914. São Paulo: EDUSP, 2006 (originalmente Tese de Doutorado, 2001).

BARBUY, Heloisa. "Museus, exposições e cidades: cultura visual no século XIX". In: BARBUY, Heloisa. A Exposição Universal de 1889 em Paris: visão e representação na sociedade industrial. São Paulo: História Social USP/ Loyola, 1999 (originalmente Dissertação de Mestrado, 1995).

BUREAU INTERNATIONAL DES EXPOSITIONS. Site officiel : http://www. bie-paris.org

COMMENT. Bernard. Le XIXe siècle des panoramas. Paris: Adam Biro, 1993.

CORREIO PAULISTANO. São Paulo, 1854; 1858; 1875; 1895.

CUNHA, Cínthia da Silva. As exposições provinciais do Império: a Bahia e as exposições universais (1866 a 1888). Salvador, 2010. Dissertação de Mestrado - História Social/UFBA.

DIKOVITSKAYA, Margaret. Visual Culture: the Study of the Visual after de Cultural Turn. Cambridge, Mass.: The MIT Press, 2006.

FOOT HARDMAN, Francisco. Trem fantasma: a modernidade na selva. São Paulo: Companhia das Letras, 1988.

GEPPERT, Alexander C.T.; COFFEY, Jean; LAU, Tammy. International Exhibitions, Expositions Universelles and World's Fairs, 1851-2005: a Bibliography. 2006. URL: http://www.lib.csufresno.edu/subjectresources/specialcollection/worldfairs/ExpoBibliography3ed.pdf.

GEORGEL, Chantal (dir.) La jeunesse des musées: les musées de France au XIXe siècle. Paris: Musée d'Orsay/Réunion des Musées Nationaux, 1994.

GROLA, Diego Amorim. A Memória nas Arcadas: construção material, simbólica e ideológica do edifício da Faculdade de Direito do Largo de São Francisco. São Paulo, Relatório de pesquisa de Iniciação Científica apresentado à FAPESP, 2009. 
HOOPER-GREENHILL, Eilean. Museums and the Interpretation of Visual Culture. London: Routledge, 2000.

LIMA, Paula Coelho Magalhães de. A Exposição de 1917 em São Paulo: Representações do industrialismo na metrópole nascente. São Paulo, Relatório de pesquisa de Iniciação Científica apresentado à FAPESP, 2008.

MARTINS, Ana Luiza; BARBUY, Heloisa. Arcadas: história da Faculdade de Direito do Largo de São Francisco, 1827-1997. São Paulo: Alternativa/ BMF, 1998.

OLIVEIRA, C.H.S.; BARBUY, H. (orgs.) Imagem e produção de conhecimento. São Paulo: Museu Paulista/USP, 2002. p.66-78.

PODGORNY, Irina. "La industria y laboriosidad de la República. Guido Bennati y las muestras de San Luis, Mendoza y La Rioja en la Exposición Nacional de Córdoba". In: DI LISCIA, María Silvia; LLUCH, Andrea (dir.). Argentina en exposición. Ferias y exhibiciones durante los siglos XIX y XX. Sevilla: Consejo Superior de Investigaciones Científicas, 2008.

(Col. Universos Americanos, 4). p.21-59.

LOPES, Maria Margaret. O Brasil descobre a pesquisa científica: os museus e as ciências naturais no século XIX. São Paulo: Hucitec, 1997. SANTOS, Paulo Coelho Mesquita. O Brasil nas exposições universais (1862 a 1911): mineração, negócios e publicações. Campinas, 2009. Dissertação de Mestrado - Instituto de Geociências/UNICAMP.

SCHAER, Roland. L'invention des musées. Paris: Gallimard, 1993. (col. Découvertes, 187)

SCHOLOSSER, Julius Von. Histoire du portrait en cire. Trad. Por Edouard Pommier. Paris: Macula, 1997. (1. ed. intitulada Die Geschichte der Porträtbildnerei in Wachs, 1911).

SCHROEDER-GUDEHUS, Brigitte; RASMUSSEN, Anne. Les fastes du progrès : le guide des expositions universelles, 1851-1992. Paris : Flammarion, 1992.

TARASANTCHI, Ruth Sprung. Pintores paisagistas: São Paulo, 1890 a 1920. São Paulo: EDUSP / Imprensa Oficial, 2002.

UNION CENTRALE DES ARTS DECORATIFS. Le livre des expositions universelles, 1851-1989. Paris : Editions des arts décoratifs/Herscher, 1983. 
Coleccionistas, aficionados y arqueólogos en la conformación de las colecciones arqueológicas del Museo de La Plata, Argentina (1930-1950)

María Alejandra Pupio

La importancia de reparar en la relación entre las prácticas profesionales y las de los aficionados ya fue señalada hace más de veinticinco años por Robert Stebbins para estudiar a los amateurs, su interacción con las comunidades científicas profesionales y su contribución a la ciencia (Stebbins 1980, 1982). La colaboración entre especialistas y aficionados fue muy estudiada para el siglo XIX e inicios del XX, cuando los científicos profesionales y las disciplinas estaban definiendo sus identidades, aunque en menor medida se observó este proceso para la mitad del siglo XX. Su estudio permite comprender que las fronteras entre profesionales y amateurs son más tenues de lo que se suele reconocer (McCray 2006).

Al abordar un período amplio como el que se desarrolla desde la década de 1930 a 1950 se pudo observar que en las prácticas de la arqueología llevadas a cabo desde el Museo de La Plata participaron los aficionados y coleccionistas. Estos conformaron un grupo heterogéneo de acuerdo al papel más o menos activo que tuvo su participación epistemológica, así como las relaciones de cooperación o tensión que establecieron con otros coleccionistas y con los profesionales.

1 Departamento de Humanidades, Universidad Nacional del Sur, apupio@bblanca.com.ar 
Durante el lapso analizado la designación del Director del Museo recayó siempre en profesores e investigadores de la casa, con tres únicas excepciones: la del historiador Ricardo Levene, la del Capitán de Fragata Guillermo Wallbrecher y la de su sucesor, José Fortunato Molfino (Teruggi 1994)2. En las tres décadas en estudio se destacan, a cargo de las colecciones arqueológicas y antropológicas, las figuras de dos investigadores, el profesor Milcíades Alejo Vignati y el doctor Fernando Márquez Miranda ${ }^{3}$. El primero ingresó al Museo de La Plata en 1930 como titular de la cátedra de Antropología y como Jefe del Departamento de Antropología. Márquez Miranda asumió como Jefe del Departamento de Arqueología y Etnografía del Museo interino ad-honorem desde 1933 y titular desde 1942 a 1947, luego de lo cual fue separado de sus funciones en la universidad durante los gobiernos peronistas. A su regreso en octubre de 1955 recuperó tanto ese cargo como sus funciones docentes. Además en 1955 fue nombrado Decano de la Facultad de Ciencias Naturales y Director del Museo. Vignati por su parte, continuó en su cargo hasta la presentación de los trámites de jubilación en 1957.

Ambos profesores marcaron fuertemente, como Jefes de Departamento, sus concepciones acerca de la práctica arqueológica y de la relación con el extramuro académico. Por esta función estaban a cargo de diversas actividades como: dictar clases en cátedras para alumnos de la Escuela de Ciencias Naturales y de correlación para los profesorados, admitir o rechazar donaciones y compras de colecciones, responder a las solicitudes de los vecinos e instituciones, catalogar las colecciones existentes, remodelar y conservar los materiales, realizar calcos de piezas para la cátedra y la exposición y diseñar las salas para público asignadas a cada departamento ${ }^{4}$.

2 Fueron directores: Augusto Scala (botánico, 1932-1933), Ricardo Levene (historiador, 1933-1934), Joaquín Frenguelli (médico, geólogo, 1934-1946), Emiliano J. Mac Donagh (zoólogo, 1946-1949), Guillermo Wallbrecher (1950-1952), Fortunato Molfino (botánico, 1952-1953), Joaquín Frenguelli (1953-1955), Tomás Suero (geólogo, 1955-1955), Fernando Márquez Miranda (1955-1957), Sebastián A. Guarrera (botánico, 1957-1964).

3 Fernando Márquez Miranda (1897-1961). Abogado de profesión, se recibió de Doctor en Filosofía y Letras (con una tesis sobre arqueología argentina) en la Universidad Central de Madrid en 1936. Inició su carrera docente en 1923 como profesor de Prehistoria Argentina y Americana en Facultad de Humanidades y Ciencias de la Educación de esa universidad. Continuó con sus cargos docentes y como Jefe del Departamento de Arqueología y Etnografía de la UNLP hasta su muerte (Lafón 1960-1965 a y b).

Milcíades Alejo Vignati (1895-1978). Egresó en 1915 como Maestro y en 1918 como Profesor en Ciencias. Fue docente de la Facultad de Filosofía y Letras de la UBA hasta 1930 y a partir de ese momento de la Universidad Nacional de La Plata.

4 Esta estructura fue definida en períodos anteriores al descripto en este trabajo (García 2005, 2010). 
Esta indiferenciación práctica entre las funciones docentes, científicas y de exposición recargaba las tareas en cada departamento, especialmente las de sus Jefes, por lo que se observan constantes reclamos elevados a los respectivos directores requiriendo cargos técnicos. Asimismo se demandaban fondos para replantear la exposición al público, que en líneas generales no había sufrido modificaciones desde que fuera organizada durante la dirección de Luis María Torres (1920-1932) (Podgorny 1999). Por otro lado esta concentración de funciones les daba autoridad para decidir sobre la formación de discípulos y el trabajo de campo, así como para establecer relaciones con los aficionados y coleccionistas en cuanto al ingreso de nuevas colecciones e información.

La comunicación que establecían Vignati y Márquez Miranda con particulares e instituciones del país estuvo orientada a dar respuesta a los pedidos escolares de material para museos, gabinetes o cajas didácticas. Por otro lado esta comunicación les permitía aconsejar a los aficionados o coleccionistas respecto de la recolección en el campo, del envío de material o sugerir bibliografía para distintos temas. En las tres décadas analizadas la correspondencia con particulares e instituciones locales que se conserva en el Archivo Histórico del Museo suma 365 cartas enviadas desde diversos territorios nacionales o provincias, siendo Buenos Aires la más representada 5 . En todo el período dominó la correspondencia de particulares, aunque esta disminuyó en la década de 1950 en un 59,6\% respecto a la anterior. Es probable que los vecinos en la década de 1950 hayan direccionado sus consultas a los museos locales, regionales y provinciales debido al afianzamiento de estas instituciones en esas jurisdicciones.

Los motivos por los que los particulares se comunicaban con las autoridades del museo eran el ofrecimiento de venta de objetos, el envío de materiales para su estudio, la solicitud de información o materiales de exposición y el aviso de hallazgos, en menor medida se ofrecían donaciones o canjes. En este grupo se puede distinguir entre coleccionistas y aficionados de acuerdo al papel que ocupaban en la recolección e identificación de hallazgos en el campo. La primera categoría incluía a aquellos individuos que se dedicaban a la recolección sistemática de material para conformar una colección particular. Por su parte el grupo de los aficionados reunía a aquellos entusiastas de la ciencia atraídos por lecturas o por noticias periodísticas, animados por la excepcional

5 La administración del Museo recibió también correspondencia de Catamarca, Chaco, Chubut, Córdoba, Corrientes, Entre Ríos, Jujuy, La Pampa, La Rioja, Mendoza, Misiones, Neuquén, Río Negro, Salta, San Juan, San Luis, Santa Cruz, Santa Fe, Santiago del Estero y Tucumán. 
situación que los hacía eventuales protagonistas de un hallazgo y fortuitos poseedores de objetos que potencialmente podrían ofrecer un aporte al devenir científico.

Los coleccionistas ponían a disposición de los arqueólogos sus materiales para el análisis. Solían invitarlos para que conocieran los objetos, se ofrecían a recolectar el material en nombre del museo con el fin de ampliar las colecciones y brindaban información y logística para efectuar las excursiones institucionales. Para que este sistema se consolidara los museos en general usaban el sistema de corresponsales, que colocaba a algunos de estos coleccionistas como intermediarios entre los vecinos y los arqueólogos (García y Podgorny 2001). Un ejemplo de esta situación lo constituyeron los viajes de Alejo Vignati a la región del lago Nahuel Huapi, en 1933 y 1935, por noticias suministradas por el sistema de corresponsales. Estos individuos le proporcionaban datos sobre la existencia de lugares con hallazgos considerados relevantes (Vignati 1935).

En cuanto a los aficionados, en general anunciaban hallazgos en ocasión de trabajos rurales o de construcción. Estos vecinos daban pruebas de autenticidad de los materiales que presentaban ante el Museo, a través del envío directo del objeto, de su dibujo o de referencias de vecinos "influyentes" que dieran legitimidad a los mismos. Por otro lado ofrecían su colaboración o solicitaban información, bibliografía o asesoramiento para el tratamiento de los objetos. Los datos que proporcionaban eran de suma utilidad, tal como lo atestiguan las salidas formales realizadas luego del envío que efectuara algún particular. Es el caso, en el año 1944, de un viaje que realizó Vignati a Los Talas por la donación de un cráneo y otros huesos humanos realizada por un vecino. El viaje exploratorio le permitió extraer un conjunto de cráneos y esqueletos que le interesaron particularmente para sus propias investigaciones (Vignati 1944).

Tanto los coleccionistas como los aficionados manifestaban la necesidad de tener cierta preparación para comprender algunos temas sobre el poblamiento indígena, así como conocimiento sobre los hallazgos y los potenciales lugares para obtener materiales. Este requerimiento era atendido especialmente por Fernando Márquez Miranda, quien recomendaba lecturas y procedimientos. En una oportunidad un comerciante aficionado de Punta Alta, una ciudad de la provincia de Buenos Aires, le solicitó que le indicara bibliografía con láminas de los "diversos artículos" que elaboraban los indígenas, para realizar la clasificación y presentar las piezas que poseía. Se trataba de una colección de 15 cajones de piezas líticas entre las que se contaba con 1400 "flechas" recogidas en la Patagonia cuando Mario Romolini Fidanza había sido inspector del ferrocarril y empleado de compañías petroleras. Márquez Miranda le 
respondió con el objetivo de que el aficionado se familiarizara con los problemas etnográficos y arqueológicos de la Patagonia. Le propuso comenzar con manuales generales para luego ascender a la lectura de obras especializadas donde encontraría abundante información gráfica para identificar las piezas de sus colecciones y establecer la clase de instrumentos que se trataba en cada caso. De todos modos le advertía que no era una tarea simple "pues de otra suerte sería demasiado fácil improvisarse arqueólogo y los especialistas estarían demás". Así, le indicaba que estos aprietos los encontraría al intentar clasificar algunos objetos especiales como las placas grabadas y los "tokis" o cetros de mando. En ese caso le señalaba que si bien existía una nutrida bibliografía especializada, se necesitaba de una alta preparación en arqueología para poder clasificarlos y describirlos. Es por eso que le aconsejaba enviar dichos materiales al Museo para su estudio y clasificación, como lo hacían otros coleccionistas. Con esta estrategia, Márquez Miranda aseguraba el ingreso de objetos que particularmente le interesaban a él. Por eso garantizaba la presencia del nombre del donante en la publicación académica, en agradecimiento por su contribución al adelanto de la ciencia, así como la exhibición de la pieza en las salas del museo, y el envío de un calco en yeso con los colores del objeto original. Márquez Miranda le hizo llegar estos datos para que sepa que "ello le permitiría sin desmedro de su colección y hasta aumentando, por el contrario, su importancia, figurar en el número de los que han contribuido a allegar esfuerzos en pro de nuestras disciplinas científicas" ${ }^{\text {. }}$.

Los datos ofrecidos por coleccionistas y aficionados configuraban una suerte de mapa arqueológico del cual se servían los profesionales para conocer nuevas áreas, para confirmar datos o para continuar el trabajo en un yacimiento determinado. En este sentido la comunicación con los lugareños fue parte de la práctica de la arqueología, que permitía obtener datos de campo en un contexto donde las exploraciones científicas subsidiadas por las instituciones no alcanzaban a cubrir las necesidades de información. Por otro lado eran pocos los profesionales dedicados a la arqueología en el país. En el caso de la universidad platense ésta fue desarrollada por Alejo Milcíades Vignati y Fernando Márquez Miranda con la participación de Enrique Palavecino, hasta el ingreso de Alberto Rex González y Osvaldo Menghin en la década de $1950^{7}$. Estos dos sólo dedicados a la actividad de investigación y docen-

6 Archivo Histórico Museo de La Plata (AHMLP) C63 1942-1944, Expte R 56, año 1943.

7 En la primera etapa se sumó a estos dos investigadores Enrique Palavecino (1900-1966) en 1933 como Profesor de la cátedra de Antropología a cargo de los Trabajos Prácticos. En la década de 1950 se incorporaron Alberto Rex González (1918) y Osvaldo Menghin (1888-1973). El primero de ello se 
cia. La concentración de tareas académicas y de extensión que requerían los cargos de jefe de departamento, restringía la experiencia de campo a una salida anual, con lo que la cobertura de áreas de investigación se producía a un ritmo lento.

Esta escasez de profesionales fue resuelta con el establecimiento de relaciones extra académicas, que tal como señaló Podgorny (2009) permitió conformar un ejército de aficionados que vivía en el campo, lo conocía mejor, accedía a los materiales y estaba dispuesto a colaborar con la empresa científica. Para esto fue necesario entonces establecer redes que dejaran obtener hallazgos en un vasto territorio, detectar aquellos de interés y establecer relaciones con los vecinos que consintieran el acceso a esos sitios. Por otro lado fue necesario entrenar a coleccionistas y aficionados a través del envío de cartas y de bibliografía para que pudieran actuar en el campo con los requerimientos necesarios para la extracción, la documentación, la conservación y el traslado de los materiales. De este modo quedó constituida una topografía del conocimiento que incluyó diversas locaciones, entre las que se encontraban el lugar donde se obtenían los materiales (el campo) y el sitio donde se generaba el conocimiento y la exhibición en las salas del museo (Livingstone 2003, Nylor 2005). Los profesionales del Museo de La Plata tuvieron una legitimidad académica que trascendía los límites de la institución. Esto fue posible porque una amplia franja de la sociedad accedió a la educación científica a través de la edición de obras de divulgación, la aparición de noticias, de reportajes y de notas sobre el desarrollo de la arqueología argentina en los diarios nacionales, los programas radiales y más tarde los televisivos. Como señala Podgorny (2004) desde la década de 1930 el cinematógrafo, las ediciones dominicales ilustradas de los diarios y la incorporación de los "monumentos y lugares" a los circuitos turísticos del Automóvil Club Argentino formaban parte de los "nuevos" medios a través de los cuales se realizaba la divulgación del plan para la educación histórica y social de la juventud y del pueblo.

Por otro lado, cabe señalar que estas prácticas convivieron con la vigencia de la Ley $N^{\circ} 9080$ como el marco legal que establecía a los bienes arqueológicos como de dominio público ${ }^{8}$. A pesar de lo prescripto

incorporó al Museo en 1949 como Profesor Adjunto de la Cátedra de Antropología en la que era Titular Micíades Alejo Vignati, el segundo fue contratado en 1950 para realizar una serie de excavaciones arqueológicas en yacimientos de la provincia de Córdoba junto a González.

8 La Ley Nacional N 9080 fue sancionada en 1913 y reglamentada en 1921. Esta ley declaraba propiedad de la nación las Ruinas y Yacimientos Arqueológicos y Paleontológicos de interés científico, y confería al Ministerio de Justicia e Instrucción Pública de la Nación la facultad de otorgar permisos (sólo a instituciones científicas nacionales o extranjeras) para utilizar o explotar dichos yacimientos 
por esta ley, el coleccionismo y la actitud del aficionado eran vistos como repertorios legítimos del trabajo de campo, incluso se reconocía la propiedad privada de la colección. En este sentido, se registraron varios casos en los que los propietarios y herederos ofrecieron en venta sus colecciones, destacándose aquellos que poseían objetos del Noroeste o de la Patagonia. Ante la oferta, el procedimiento era el siguiente: el Jefe de cada Sección realizaba una valoración de la colección según criterios de autenticidad, valor monetario, documentación y presencia o ausencia de esos items en las colecciones del Museo. Algunas de las evaluaciones estaban a cargo de Fernando Márquez Miranda, quien en general desestimaba la compra de colecciones provenientes de Patagonia, ya que el Museo de La Plata poseía voluminosos conjuntos de igual procedencia y situación de hallazgo en superficie. Sólo recomendaba la compra de algunas piezas especiales y "fuera de serie". Iguales parámetros utilizaba Milcíades Alejo Vignati, quien en 1946 rechazó la compra de la colección de 282 piezas líticas del lago Colihué Huapi de Rodolfo Faggioli al precio que la ofreció su esposa. Por el contrario sólo señaló que podrían ser de interés a un costo mínimo de 25 centavos la pieza o 50 pesos el lote 9 . Un caso interesante fue la recomendación de compra que realizó Fernando Márquez Miranda sobre la colección de Enrique Artayeta ${ }^{10}$. En 1938 la ofreció en venta a la Dirección de Parques Nacionales del Ministerio de Agricultura de la Nación para que fuera exhibida en el edificio del Museo que se construía en el Centro Cívico de San Carlos de Bariloche. El arqueólogo consideró que a pesar de que la colección lítica no revestía importancia científica ni venal por la enorme abundancia que había de ese material en los museos nacionales, el notable interés de los materiales de hueso, madera, metal y los tejidos valían la compra de la colección.

La práctica de coleccionar era aceptada y promovida, y se la distinguía de la que tenía como objetivo el beneficio económico. De este modo se oponía a los "coleccionistas y aficionados", como los llamaba usualmente Vignati, de aquellos que eran considerados, al menos públicamente, como saqueadores a los que caracterizaban por una actitud lucrativa en la acción del coleccionar. El mismo Vignati señalaba que

con el asesoramiento de los museos Nacional de Historia Natural, Etnográfico de la Facultad de Filosofía y Letras de la Universidad de Buenos Aires y el Museo de La Plata (Endere y Podgorny 1997, Podgorny 2000)

9 Rodolfo Faggioli fue un médico cirujano instalado en la ciudad de Necochea, provincia de Buenos Aires quien poseía una colección producto de sus búsquedas en el litoral atlántico y en el río Quequén Grande. A la muerte del coleccionista, parte de su colección fue vendida, y el resto se encuentra en el Museo de Ciencias Naturales de Necochea. AHMLP C 70 1945-1947, Exp F 638, año 1946.

10 Informe de Fernando Márquez Miranda, AHMLP C 27 1936-1938, Exp. D 163, año 1938. 
por la acción negativa de aquellos individuos en los alrededores del lago Traful, los materiales habían sido saqueados "despiadadamente por los lugareños ávidos de proporcionar a los turistas recuerdos de "color" local" (Vignati 1935). Esta idea de diferenciar la acción de los particulares que actuaban en relación con los investigadores de la de los individuos que tenían afán de lucro personal, ya la había expresado al publicar en 1931 su estudio sobre los materiales de la costa del sudoeste de la provincia de Buenos Aires.

Los pobladores de la región, en efecto, inconscientes del mal irremediable que realizan, vienen practicando una verdadera depredación de los que fueron riquísimos repositorios de nuestro pasado arqueológico. Añádase a estas destrucciones, que no tienen más justificativo que la ignorancia de los autores, las que ejecutan personas de cierta instrucción que, sin método ni garantía alguna de la procedencia del material que recogen o compran, esquilman los yacimientos y las colecciones particulares. Este hecho es tanto más repudiable cuanto que, naturalmente, los destinatarios de esas colecciones son institutos científicos o estudiosos que, de buena fe, les otorgan un estado civil que, por cierto, no merecen (Vignati 1931: 20).

Contra estos individuos, que practicaban una recolección indiscriminada, sin control de procedencia y con objeto de comercializar, Vignati pedía la aplicación de la Ley de Yacimientos 9080. De este modo el status de estas acciones "lucrativas" se diferenciaba de la colección sistemática de amateurs, una acción aceptada en la práctica de campo.

En la década de 1950 lentamente aparecieron algunas voces académicas, como la del Dr. Alberto Rex González, que comenzaron a percibir en la acción de los coleccionistas una competencia peligrosa. Al regresar al país en 1948 tras finalizar su doctorado en la Universidad de Columbia (Estados Unidos), se dedicó de forma exclusiva a desarrollar la investigación. En el marco de sus proyectos realizó campañas arqueológicas extensas y reiteradas, especialmente al noroeste argentino, aplicando métodos de excavación novedosos en la práctica local. Al regreso de uno de estos viajes en 1954, elevó un informe al Dr. Joaquín Frenguelli para advertirle sobre el incumplimiento de la ley 9080. Señalaba el saqueo y la depredación como consecuencia del activo comercio de antigüedades para coleccionistas de Buenos Aires y del extranjero. En tono profético anunciaba que "si sigue este estado de cosas habrán sido 
totalmente destruidos en pocos años impidiendo en el futuro toda posibilidad de investigación científica de nuestro pasado aborigen"11.

El tono asumido por González comenzó a ser más reiterado en la segunda mitad de la década de 1950. A partir de ese momento, se volvían a repetir, como en épocas anteriores (cf. García 2010), las disputas personales que ahora se solapaban con las políticas y la pelea por los espacios de investigación (puestos, lugares, trabajo de campo) como parte de la dinámica académica. En este contexto deben ser comprendidas las declaraciones de Fernando Márquez Miranda al señalar que:

Existe en la Argentina una ley nacional, la № 9080, que crea, con todos los directores de los tres grandes museos argentinos, la Comisión Nacional de Yacimientos Arqueológicos y Paleontológicos. Pero es una ley totalmente muerta. Nadie la conoce. Nadie la respeta. Nadie la hace cumplir. Podemos decir que su alcance se reduce a dar el instrumento legal para que eventualmente se pudiera perseguir con él a un profesional conocido, a quien, previamente, se le hubiese privado de su cargo en un Museo, pero no es ninguna barrera para que quien quiera excave o destroce los yacimientos que se le de la gana (Márquez Miranda 1959: 19).

Márquez Miranda, como primer director de la flamante carrera de Antropología de la Universidad de Buenos Aires (1958-1961), proponía la revitalización del instrumento legislativo a través de la consulta a los científicos. Señalaba, a diferencia de una década atrás, que los arqueólogos aficionados establecían una abierta competencia a los oficiales, gozaban de muy buena prensa y hasta se daban el lujo de obsequiar partes de sus hallazgos a las más altas autoridades de la nación. Por este motivo se debía actualizar la ley destinada a evitar la "excavación clandestina disfrazada de hobbie".

Estos argumentos ya habían sido esgrimidos para propiciar la carrera de Ciencias Antropológicas de la Universidad de Buenos Aires. Los arqueólogos que propugnaban la creciente necesidad de profesionalización y de delimitación de incumbencias veían ahora como competencia la acción de los amateurs que manejaban los museos de la provincia y que poseían colecciones arqueológicas que consideraban debían ser estudiadas por especialistas. La intervención de Bunge en la sesión del

11 AHMLP, Expte G 310- 1952, año 1954. 
Consejo Directivo de la Facultad de Filosofía y Letras del 1 de setiembre de 1958, con referencia a los debates que precedieron a la creación de la carrera de Antropología señalaba que

\begin{abstract}
El país necesita contar con un grupo adecuado de graduados en ciencias antropológicas. En la actualidad hay muchas instituciones que carecen del personal técnico adecuado. Hay once museos, institutos y departamentos universitarios que se ocupan de estas materias; existen aproximadamente diez museos provinciales, casi todos en manos de "amateurs", y no menos de dieciséis cátedras en todo el país. También es necesario tener en cuenta el trabajo de campaña a regiones enteras que deben ser exploradas, y colecciones en manos de particulares que deben ser clasificadas (citado por Visacovsky et al. 1997: 226).
\end{abstract}

El fin del período analizado estuvo signado por la creación de la carrera de Antropología en las universidades de La Plata (1957) y Buenos Aires (1958) y la creación del Consejo Nacional de Investigaciones Científicas y Técnicas $(1958)^{12}$. De este modo, comenzó a perfilarse la carrera científica y el acceso a todos aquellos que pudieran exhibir credenciales profesionales. Empezaron a multiplicarse las condenas públicas al amateurismo, incluso en personas que pocos años antes habian sido soporte de un sistema de cooperación entre profesionales y coleccionistas y aficionados como práctica arqueológica. En los años venideros la discusión acerca del marco legal y de las incumbencias profesionales será un tema recurrente entre los arqueólogos. Sin embargo, esta situación no significó el fin de la práctica amateur, que aunque desaprobada públicamente, siguió siendo parte de las acciones cotidianas en ciudades de provincia.

\title{
Agradecimientos
}

Agradezco las sugerencias de las Dras. Susana García e Irina Podgorny.

12 Sin embargo la formación especializada en Ciencias Antropológicas se remonta a la primera década del siglo XX tanto en la Universidad Nacional de La Plata (García 2003) como en la Universidad de Buenos Aires (Visacovsky et al. 1997). 


\section{Referencias bibliográficas}

Endere, M.L. e I. Podgorny.1997. Los gliptodontes son argentinos: la ley 9080 y la creación del patrimonio nacional. Ciencia Hoy 7 (12): 54-59.

García, S. 2003. La formación universitaria en ciencias naturales en el Museo de La Plata a principios del siglo XX. En Historias de la Ciencia Argentina, tomo I, editado por C. Lorenzano: 4-51. EDUNTREF, Buenos Aires.

2005. Discursos, espacios y prácticas en la enseñanza científica de la universidad platense. Saber y Tiempo 20: 19-62.

2010. Enseñanza científica y cultura académica. La Universidad de La Plata y las Ciencias Naturales (1900-1930). Prohistoria ediciones, Rosario.

García, S. y Podgorny, I. 2001. Pedagogía y nacionalismo en la Argentina: lo internacional y lo local en la institucionalización de la enseñanza de la arqueología. Trabajos de Prehistoria 58 (2): 9-26.

Lafón, C. 1960-1965a. Recordación del Doctor Fernando Márquez Miranda. Runa X(1-2): 7-15.

1960-1965b. Curriculum vitae del profesor doctor Fernando Márquez Miranda. Runa X (1-2): 16-51.

Livingstone, D. 2003. Putting Science in Its Place: Geographies of Scientific Knowledge. University of Chicago Press, Chicago.

Márquez Miranda, F. 1959. La preservación de monumentos históricos, artísticos, arqueológicos y objetos folklóricos. Boletín de la Dirección de Museos II: 19-23.

McCray, P. 2006. Amateur scientists, the International Geophysical Year, and the ambitios of Fred Whipple. Isis 97: 634-58.

Naylor, S. 2005. Introduction: historical geographies of science -places, contexts, cartographies. BJHS 38 (1): 1-12.

Podgorny, I. 1999. De la antigüedad del hombre en el Plata a la distribución de las antigüedades en el mapa: los criterios de organización de 
las colecciones antropológicas del Museo de La Plata entre 1897 y 1930. História, Ciências, Saúde-Manguinhos 6 (1): 81-101.

2000. El argentino despertar de las faunas y las gentes prehistóricas. Buenos Aires, EUDEBA.

2004. Tocar para creer. La arqueología en la Argentina, 1900-1940. Anales Del Museo de América 12: 147-182.

2009. El sendero del tiempo y de las causas accidentales. Los espacios de la antigüedad del hombre en el Plata, 1850-1910. Prohistoria, Rosario.

Stebbins, R. 1980. Avocational science: The Amateur routine in Archaeology and Astronomy. International Journal of Comparative Sociology 21: 34-48.

1982. Amateur and Professional Astronomers: A study of their interrelationships. Urban Life 10: 433-454.

Teruggi, M. 1988. Museo de La Plata, 1888-1988. Una centuria de honra. Fundación Museo de La Plata, La Plata.

Vignati M. 1931. Investigaciones antropológicas en el Litoral Marítimo Sudatlántico Bonaerense. Notas preliminares del Museo de La Plata, tomo I.

1935. Informe Departamento de Antropología. Revista del Museo de La Plata (Nueva Serie): 36-37

1944. Informe Departamento de Antropología. Revista del Museo de La Plata (Nueva Serie):3-5.

Visacovsky S., R. Guber y E. Gurevich. 1997. Modernidad y tradición en el origen de la carrera de Ciencias Antropológicas de la Universidad de Buenos Aires. REDES 10: 213-257. 